\title{
DEKONSTRUKSI PUISI "THE DIVINE COMEDY" \\ KARYA DANTE ALIGHIERI DALAM NOVEL 'INFERNO' KARYA DAN BROWN
}

\section{TESIS}

\section{Untuk Memenuhi Sebagian Persyaratan \\ Mencapai Gelar Master}

Program Studi Ilmu Sastra

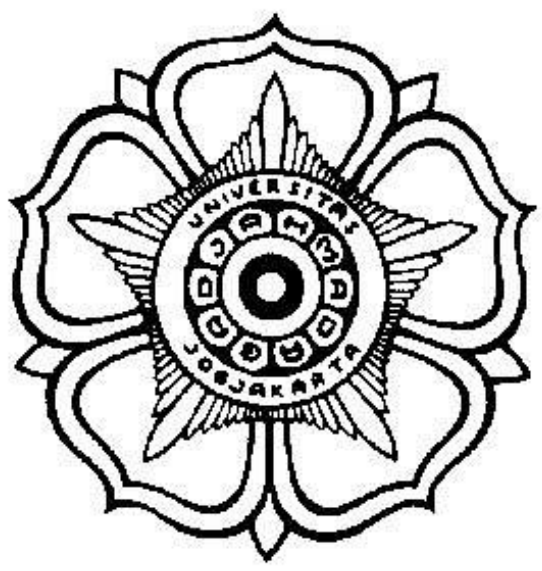

Diajukan oleh :

Zulkifli. M

12/337395/PSA/07194

Kepada

PROGRAM PASCASARJANA ILMU SASTRA

FAKULTAS ILMU BUDAYA

UNIVERSITAS GADJAH MADA

YOGYAKARTA 


\section{DECONSTRUCTION OF DANTE ALIGHIERI'S “THE DIVINE COMEDY" IN DAN BROWN'S NOVEL 'INFERNO'}

\section{A THESIS}

Presented to the Board of Examiners In Partial Fulfillment of the Requirement for Master Degree in Literature Studies Program

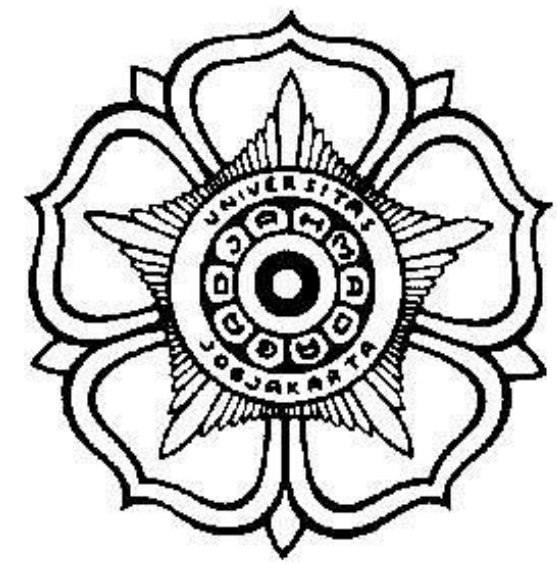

Proposed by:

Zulkifli. M

12/337395/PSA/07194

To

POSTGRADUATE PROGRAM OF LITERATURE STUDIES

FACULTY OF CULTURAL SCIENCE

GADJAH MADA UNIVERSITY

YOGYAKARTA 
HALAMAN PENGESAHAN

TESIS

\title{
DEKONSTRUKSI PUISI "THE DIVINE COMEDY" KARYA DANTE ALIGHIERI DALAM NOVEL 'INFERNO' KARYA DAN BROWN
}

\author{
dipersiapkan dan disusun oleh \\ Zulkifli. M \\ 12/337395/PSA/07194
}

Telah dipersiapkan di depan Tim Penguji Tesis

Pada tanggal 24 Agustus 2015

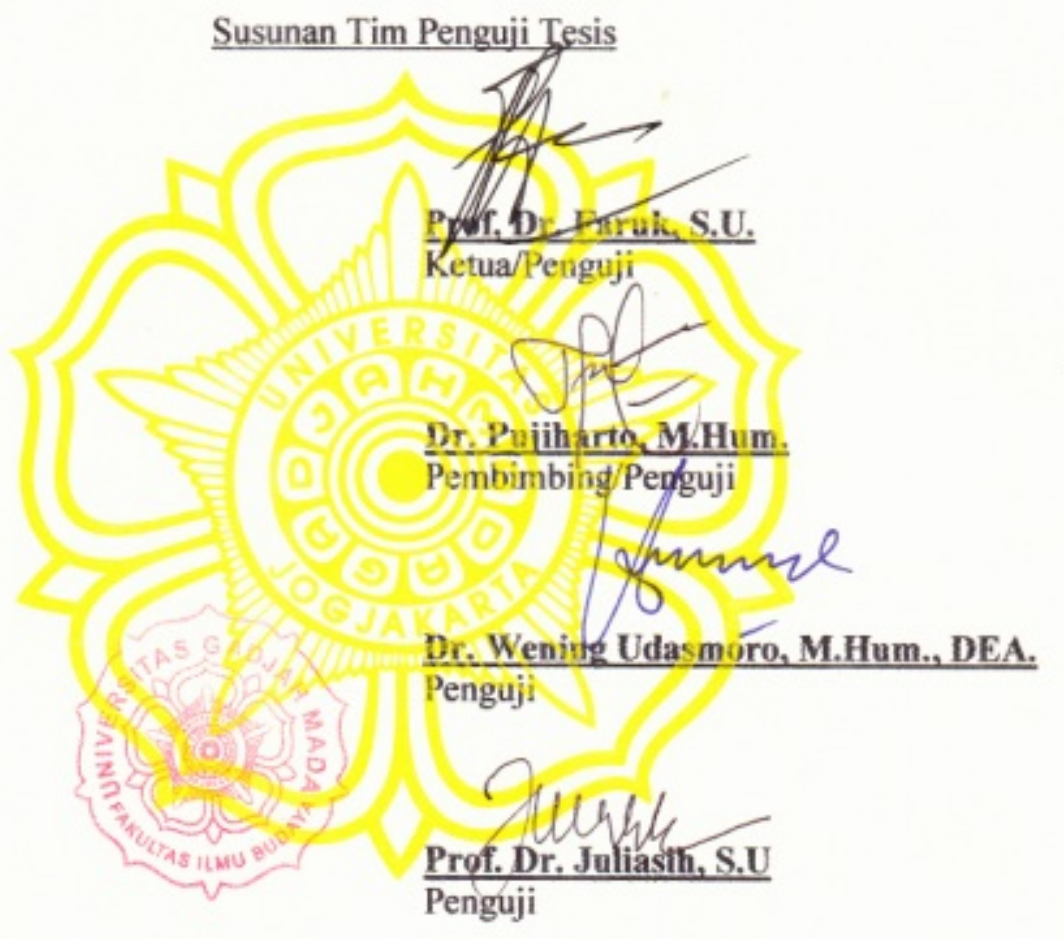

Tesis ini telah diterima sebagai salah satu persyaratan untuk memperoleh gelar Master pada tanggal 24 agustus 2015

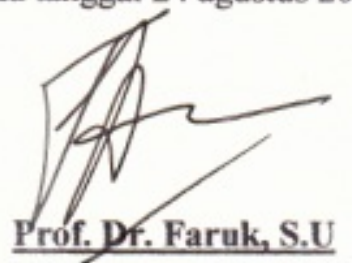

Ketua Pengelola Program Studi S2 Ilmu Sastra 


\section{PERNYATAAN}

Dengan ini saya menyatakan bahwa dalam tesis ini tidak terdapat karya yang pernah diajukan untuk memperoleh gelar keserjanaan di suatu Perguruan Tinggi, dan sepanjang pengetahuan saya juga tidak terdapat karya atau pendapat yang pernah ditulis atau diterbitkan oleh orag lain, kecuali yang tertulis dalam naskah ini dan disebutkan dalam daftar pustaka.

Yogyakarta, Agustus 2015

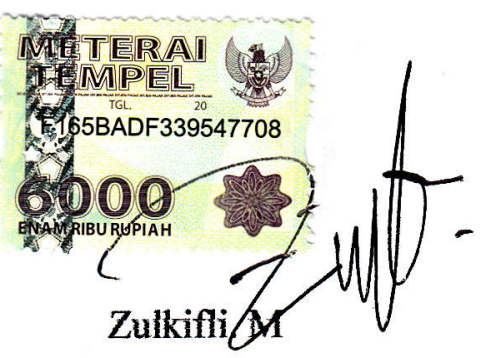

12/337395/PSA/07194 
Ye of intellect sound entire, mark well the lore conceal'd under close texture of the mystic strain (Dante Alighieri) 
Untuk ibuku dan malaikat di sepertiga malam yang tak lelah mengamini doa-doanya. 


\section{KATA PENGANTAR}

Puji syukur penulis panjatkan kehadirat Allah SWT karena atas limpahan rahmat, hidayah, dan petunjuk-Nya sehingga penulis dapat menyelesaikan tesis berjudul 'Dekonstruksi 'The Divine Comedy' Karya Dante Alighieri dalam novel 'Inferno' Karya Dan Brown'. Proses penyusunan tesis untuk memperoleh gelar strata dua (S2) dari Fakultas Ilmu Budaya UGM ini tidak dapat berjalan lancer tanpa bantuan dan dukungan dari berbagai pihak. Oleh karena itu, penulis menyampaikan banyak terima kasih setulus-tulusnya atas segala bimbingan, dukungan, dan bantuan selama proses studi dan selama penyusunan tesis ini.

Terima kasih kepada Dr. Pujiharto, M.Hum., selaku dosen pembimbing yang telah mengarahkan penulis. Terima kasih kepada Prof. Dr. Faruk H.T., S.U., selaku ketua Program Studi S-2 Ilmu Sastra, Fakultas Ilmu Budaya, UGM. Terima kasih kepada Dr. Juliasih, S.U., dan Dr. Wening Udasmoro, M.Hum, DEA., selaku Komisi Akademik dan Dewan Penguji.

Terima kasih kepada Dr. Pudjo Semedi Hargo Yowono, M.A., selaku Dekan Fakultas Ilmu Budaya yang telah memberikan kesempatan kepada penulis untuk menimba ilmu di Fakultas Ilmu Budaya, UGM. Terima kasih juga penulis sampaikan atas curahan ilmu pengetahuan dari dosen-dosen Prodi S2 Ilmu Sastra Fakultas Ilmu Budaya UGM. 
Tak lupa pula penulis sampaikan terima kasih kepada segenap civitas akademik dan seluruh staf akademik Fakultas Ilmu Budaya UGM, dan petugas perpustakaan Fakultas Ilmu Budaya UGM. Teman-teman Prodi S2 Ilmu Sastra angkatan tahun 2012. Selain itu, penulis juga mengucapkan terima kasih kepada teman-teman diskusi dan berdialog yang menginsipirasi dan memotivasi penulis, Dwi Raharyoso, Agus Satriyo Raharjo, Anis Maslihatin, Shabrina An Adzhani, Dharma Satya H.D, Ima Dyah Savitri, Nanang Saiful Rohman, Marleni, Teguh Tri Wahyudi, Chris Woodrich, Hayu Avang, Latif S. Nugraha, Fitri Merawati, Jiphie Gilia, Andriadi. Seluruh kawan-kawan asrama mahasiswa kab. Takalar WISMA PANRANNUANGKU atas sepenggal suasana, keakraban yang tidak terlupakan bang Udin dan keluarga, Imam, Firman, Ancu, Didin, Anca, Asrul, Eni, Ayu, Nini, Aci, Tirta, Puji, Edib, Wawan, Awa, dan Widi.

Orang tua tercinta Makmur. S dan Herlina. L, terima kasih atas doa tulus, dukungan, dan dorongan mental maupun maupun material yang senantiasa memberikan semangat untuk menyelesaikan tesis ini. Kedua adik dan saudara sepupu Dita Pharadiba. M, Faisal. M dan Jefri.

Teristimewa untuk Cucum Cantini, matahari mungil yang membuatku selalu terjaga bahkan saat matahari Sang Logos membagi energinya di belahan bumi yang lain. 
Menyadari bahwa masih begitu banyak kekurangan dalam tesis ini, penulis senantiasa membuka kesempatan untuk kritik dan saran dari pembaca. Akhirul kalam, semoga tesis ini bermanfaat.

Yogyakarta, 1 agustus 2015

Penulis 


\section{DAFTAR ISI}

HALAMAN JUDUL $\ldots \ldots \ldots \ldots \ldots \ldots$

HALAMAN JUDUL BAHASA INGGRIS _....... ii

HALAMAN PENGESAHAN _ii

HALAMAN PERNYATAAN _......... iv

KATA PENGANTAR $\quad$ ix

DAFTAR ISI $\quad x$

DAFTAR GAMBAR

DAFTAR TABEL _ xiii

DAFTAR BAGAN $\ldots$ xiv

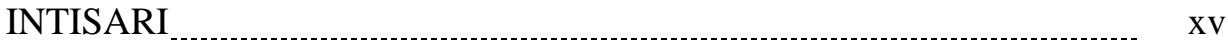

ABSTRACT

BAB I PENDAHULUAN

1.1 Latar Belakang _...

1.2 Rumusan Masalah

1.3 Tujuan Penelitian ............................................................ 11

1.4 Tinjauan Pustaka

1.5 Landasan Teori

1.5.1 Dekonstruksi dan kritik terhadap Strukturalisme .... 15

1.5.2 Ketidakstabilan Teks $\ldots 17$

1.5.3 Differance

1.5.4 Negosiasi Oposisi Biner $\quad 24$

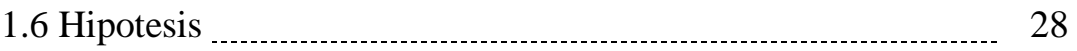

1.7 Metode Penelitian

1.8 Sistematika Penyajian _............................................. 31 
2.1 Commedia sebagai Historiografi

2.1.1 Akhir era medieval; Sengketa Guelf dan Ghibellini

\begin{tabular}{clc}
2.1 .2 & Riwayat Hidup Dante Alighieri & 32 \\
2.1 .3 & Commedia; Mitologi, Ilmu, dan Iman & 37 \\
2. & & 43 \\
2.2 .1 & Inferno & 48 \\
2.2 .2 & Purgatory & 49 \\
2.2 .3 & Paradiso & \\
\hline
\end{tabular}

2.3 Strategi Perjumpaan dalam Teks _.............................. 69

2.3.1 Autobiografi; kekangan terhadap teks .............. 69

2.3.2 Alegori; alternatif Strategi Perjumpaan _.......... 81

2.3.3 Sistem tertutup dan Gradasi Hirarki _............ 91

BAB III DEKONSTRUKSI DALAM NOVEL INFERNO

3.1 Ringkasan Novel Inferno _......................................... 148

3.2 Persinggungan Dua Ilham ........................................... 149

3.1.1 Persinggungan berupa idiom .............................. 150

3.1.2 Persinggungan secara simbolik .......................... 165

3.3 Diskursus Dekonstruksi dalam Inferno ............................... 183

3.3.1 Negosiasi dua mukjizat .................................... 184

3.3.2 Perempuan dan hasrat menghuni neraka ............... 205

BAB IV PENUTUP 220

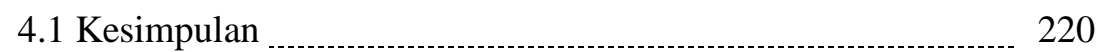

4.2 Saran _ 224

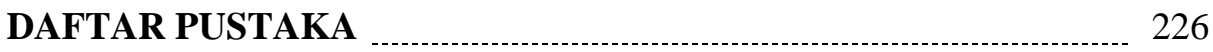




\section{DAFTAR GAMBAR}

Gambar 2.1. Visi neraka Limbo

Gambar 2.2. Ilustrasi struktur neraka _....................................... 55

Gambar 2.3. Ilustrasi struktur gunung Purgatory .............................. 62

Gambar 2.4. Ilustrasi struktur Surga $\ldots$

Gambar 2.5. Ilustrasi Bak Pembaptisan era Medieval _.................... 95

Gambar 3.1. Lambang Tragedi dan Komedi dalam drama _.............. 167

Gambar 3.2. Lambang Biohazard $\ldots \ldots \ldots$ 


\section{DAFTAR TABEL}

Tabel 2.1. Daftar alegori dalam puisi The Divine Comedy .............. 91

Tabel 2.2. Urutan perjalanan puisi The Divine Comedy .................... 103

Tabel 2.3. Urutan Hirarki eskatologi puisi The Divine Comedy ........ 121

Tabel 2.4 Daftar oposisi berpasangan _........................................... 141 


\section{DAFTAR BAGAN}

Bagan 2.1. Pola Alegori

Bagan 3.1 Skema Oposisi Biner _.................................................. 196 


\section{Intisari}

Tesis ini membahas tentang negosiasi hierarki teks puisi The Divine Comedy karya Dante Alighieri melalui novel Inferno karya Dan Brown, yang terbit mei tahun 2013. Puisi karya Dante tersebut menggambarkan susunan akhirat yang didasarkan moralitas, dan spiritualitas doktrin Kristen era medieval. Narasi abad pertengahan ini ternyata cenderung masih mempengaruhi pemikiran ideal masyarakat Eropa atau Angelo-Amerika tentang adanya keistimewaan identitas yang meliputi agama, ras, dan ideologi. Novel Inferno merepresentasikan pembaca dekonstruktif yang mengasosiasikan visi ideal Dante dan realitas kekinian. Penelitian ini bertujuan melihat bagaimana strategi teks novel Inferno mendekonstruksi visi eskatologi yang dibangun dalam teks The Divine Comedy. Pendekatan yang digunakan dalam penelitian ini adalah pembacaan dekonstruksi Jacques Derrida. Dekonstruksi mengkritik teori strukturalisme klasik yang menyatakan bahwa teks adalah sekumpulan tanda yang merepresentasikan pengarang. Teks, menurut Derrida, tidak selalu merepresentasikan pengarang. Ada jarak antara teks dan pengarang. Jarak tersebut menjadi landasan bahwa teks tidak bersifat otonom. Teks mengalami penundaan makna. Dengan demikian, hubungan antar tanda atau simbol menjadi tidak stabil. Metode yang digunakan dalam penelitian ini adalah metode pembacaan dekonstruksi. Metode ini dapat menunjukkan adanya hierarki oposisi dalam teks, sehingga tampak satuan oposisi yang diunggulkan secara sistimatik. Oposisi ini, selanjutnya, diasosiasikan dengan yang lain agar keistimewaan yang satu dengan yang lain tampak paradoks.

Penelitian ini menemukan bahwa teks The Divine Comedy adalah sebuah teks logosentris. Strategi kehadiran yang digunakan dalam mengkonstruksi logos adalah teknik autobiografi, permainan alegori, dan gradasi hierarki yang tertutup. Konstruksi Commedia juga telah menciptakan keistimewaan identitas ras Angelo-Amerika dengan menempatkan mereka dalam medan makna yang sempurna seperti beradab, diberkati, Kristen, megah, barat, pintar, dan ksatria. Dan Brown, dalam novelnya Inferno, membalikkan medan makna tersebut dan mengasosiasikannya dengan fakta naratif di balik kemegahan bangunan Hagia Sophia. Penelitian ini juga mempertanyakan kembali oposisi hierarkis di ruang gender. Novel Inferno, pada akhirnya, menarik konsep utopis Dante ke alam realitas.

Kata Kunci: Dekonstruksi, Inferno, dan The Divine Comedy. 


\begin{abstract}
This thesis explains negotiation of text hierarchy in Dante Alighieri's The Divine Comedy through Dan Brown's Novel Inferno, which was published on may 2013. The poem describes structure of eschatology based on morality, and spirituality of medieval Christianity. This narration of medieval now tends to influence the ideal view of European or AngeloAmerica people of which they believe in special identity that includes religion, race, and ideology. Inferno represents deconstructive reading which associates Dante's ideal vision and contemporary reality. This research aims to investigate the text strategy used in Inferno to deconstruct the eschatological vision created in The Divine Comedy. The approach used in this thesis is Jacques Derrida's deconstruction reading. Deconstruction criticizes the claim of classic structuralism that a text is a group of signs of which represent the author. A text, according to Derrida, does not always represent the author. There is a space between the author and his text. It strongly becomes reference that a text is not autonomous. Its meaning would be deferred. Relations among signs or symbols are thus instable. To identify deconstruction in the novel Inferno, The method used in this research is deconstruction reading. This shows hierarchy of opposition in the text, and can then reveal those which systematically are privileged. These oppositions, furthermore, are associated with others so hierarchy of the privileged and the insignificant seems paradox.

Researcher found that the text The Divine Comedy is a logocentric text. Strategies of being used to construct logos in the text are autobiography technique, allegory play, and closed hierarchy gradation. Construction of commedia also builds superiority of Angelo-America by playing in privileged semantic field such as civilized, blessed, Christian, glorious, west, brilliant, and hero. Dan Brown, by his Inferno, reverses the semantic field by associating them with narrative facts behind the history and architecture of Hagia Sophia. This research also questions hierarchical opposition in gender field. Finally, novel Inferno pulls utopian concept of Dante back the reality.
\end{abstract}

Keywords: Deconstruction, Inferno, and the Divine Comedy. 


\section{BAB I \\ PENDAHULUAN}

\subsection{Latar Belakang}

Penaklukan Andalusia oleh Khalifah Al-Walid, sejak ekspansi kerajaan Islam di bawah kepemimpinan Dinasti Umayyah di utara Jazirah Arab pada abad ke delapan, merupakan awal mula menyatunya panji-panji di daratan utara sebagai gerakan politik memukul mundur gerakan dakwah dari tanah Arab. Kesadaran moral menghalau serangan bangsa barbar ini telah menciptakan kekuatan persekutuan yang maha dahsyat, yang kini dikenal dengan nama Eropa (Lewis, 2008: 23). Menurut Wellek and Warren (1977: 86), karya sastra dapat dianggap sebagai dokumen sejarah dan pemikiran filsafat, karena sejarah sastra sejajar dan mencerminkan sejarah pemikiran. Pada saat itu, negara-negara di bawah payung Eropa ini diikat oleh sebuah pandangan filsafat teosentris, yaitu Kristen. Ini dapat dibuktikan dengan lahirnya karya-karya seni dan syair-syair religius yang merujuk pada penafsiran hermeunetik terhadap Bibel pada masa itu.

Sebagai negara yang masih menyisakan peradaban Romawi yang kokoh, Italia secara otomatis menjadi pemersatu dan sentral doktrin agama Kristen dan imperium di daratan Eropa pada saat itu (Lewis, 2008: 496). Peradaban yang gemilang dan kebudayaannya yang agung bukan hanya melahirkan crusader tangguh yang rela mengorbankan nyawanya demi kebangkitan agama, tetapi juga menelurkan seniman, dan penyair-penyair alim yang membangkitkan moral jihad, dan semangat kebangsaan serta membangun standar etis masyarakat Eropa yang tentunya bersumber dari penafsiran Bibel, ditambah kisah-kisah epos dari Virgil, 
Homer, Statius, dan masih banyak lagi, dan kekayaan mitologi Romawi dan Yunani serta penggabungan dari keduanya yang menggambarkan selama berpuluh abad keunggulan ras manusia Romawi yang merepresentasikan masyarakat Eropa pada saat itu. Penyair memiliki status dan peran yang penting dalam politik Roma pada saat itu. Salah satu diantara penyair terkemuka pada era tersebut adalah Dante Alighieri.

Dante adalah penyair asal Florance, Italia. Dalam Pengantarnya di dalam terjemahan berbahasa Inggris The Divine Comedy of Dante Alligheire, Martinez (1996) mengapresiasi bahwa Dante sangat apik dalam menafsirkan Bibel dengan mengajak manusia berjalan-jalan menelusuri kosmik dan semesta moral (Durling, 1996). Jalan hidupnya yang terbilang tragis, karena dipisahkan dari kota kelahiran dan juga kekasihnya, membuat Dante banyak menghabiskan kesendiriannya membuat penafsiran-penafsiran yang unik, menggelitik, dan sarkas terhadap pemimpin-pemimpin yang dimuliakan melalui bait demi bait syairnya. Karyakaryanya yang terkenal adalah La Convivio, yang berisi pengalaman filsafat dan gudang pemikiran Dante mengenai dunia dan pengetahuan kesusasteraan yang digelutinya. Puisi liriknya yang berisi romantika Dante bersama kekasihnya Beatrice ada pada La Vita Nouva. Adapun puisi liriknya yang merupakan puncak pencapaian filsafat dan kesusasteraannya dan masih menjadi bahan pembicaraan serius serta direproduksi ke dalam berbagai karya seni hingga kini di kalangan seniman, penganut ortodoks, bahkan ilmuwan adalah The Divine Comedy.

Commedia merupakan karya serius Dante yang menjadi perbincangan banyak kalangan, baik itu di masanya maupun saat ini. Salah satu perbincangan 
yang paling alot adalah pemilihan judulnya yang menggunakan istilah komedi. Menurut Milicent Lenz (1994: 23), Dante menggunakan istilah komedi di dalam frasal judulnya The Divine Comedy disebabkan dua faktor. Yang pertama, Dante menganggap bahwa dialek yang digunakan dalam menulis commedia adalah bahasa ibunya yang berasal dari sebuah desa kecil di Florance, jauh dari kesan high karena bahasa yang berkelas pada masa itu adalah latin Roma. Oleh karena itu, dia merasa bahwa gaya bahasa di dalam syairnya sangat rendah dan tidak mencirikan tulisan seorang yang terhormat. Yang kedua, di dalam puisi The Divine Comedy, sang penyair menemukan akhir yang bahagia setelah melalui banyak visi yang mengerikan selama proses perjalanannya menuju surga dan Tuhan, tentunya ini juga tidak memberikan kesan tragedi sebagaimana karakteristik kisah-kisah tragedi sebelumnya yang berakhir dengan kesengsaraan dan kehinaan.

Selama berabad-abad, menurut Janet Maslin (2013), pada tahun 2012, kumpulan puisi yang berbentuk trilogi ini diterjemahkan tidak kurang dari tiga puluh bahasa di seluruh dunia, terutama di negara-negara dengan pemeluk Katolik yang besar, dengan tujuan memperkenalkan khasanah kekayaan pemikiran dan kejayaan perababan Katolik di era pertengahan (The N.Y Time, 2013). Di dalam triloginya, The Divine Comedy membagi tiga topik berdasarkan alam-alam setelah kematian. Ketiga alam tersebut secara berurutan adalah Inferno sebagai neraka yang berada di dasar bumi, berisi manusia yang kekal menemui siksaan yang berat sebagai ganjaran atas dosa yang diperbuatnya selama hidup di dunia; Purgatory sebagai alam penyucian. Sebuah alam di sebelah selatan digambarkan 
dengan sebuah gunung yang menjulang tinggi di tengah lautan, dimana manusia yang memiliki jiwa-jiwa yang kotor dibersihkan di tempat ini sebelum memasuki surga; dan Paradiso sebagai surga di atas awan. Tempat bersemayamnya jiwajiwa yang tercerahkan, malaikat, para Nabi dan Yesus Kristus.

Terutama Inferno yang disusun Dante pada awal 1300-an, secara literal The Divine Comedy mengubah persepsi massa dengan cara yang begitu menakutkan. Dalam sekejap, karya Dante membuat konsep abstrak mengenai neraka menjadi visi yang jelas dan mengerikan - mendalam, gamblang, dan tak terlupakan. Tidak mengherankan, setelah penerbitan puisi itu, Gereja Katolik mengalami peningkatan jumlah pengunjung yang luar biasa dari para pendosa ketakutan yang ingin menghindari versi terbaru dunia-bawah menurut Dante (Brown, 2013: 64).

Sebagai karya sastra yang agung, Komedi Dante berhasil merebut perhatian masyarakat kristen Eropa pada saat itu dan masyarakat dunia saat ini. Ini terbukti dengan lahirnya karya-karya seni agung abad pertengahan yang mereproduksi komedi Dante yang bukan hanya ke dalam karya visual seperti lukisan, ukiran, arsitektur, dan patung tetapi juga berupa karya audio seperti gubahan musik klasik baik yang tersebar di Florance maupun di seluruh belahan dunia. Karya-karya di era pencerahan banyak terinspirasi dari Commedia Dante. Visualisasi neraka Dante oleh Boticelli dalam La Mappa Del Inferno dan karyakarya agung berupa patung oleh Michelangelo juga terinspirasi dari The Divine Comedy. Di bidang sastra dan filsafat ada Nicolo Machiavelli, dan John Milton yang juga banyak merujuk pada puisi Dante tersebut. 
Namun, sejak lahirnya karya tersebut, Dante menjadi topik perbincangan. Pertanyaan yang paling menonjol di kalangan pemikir kontemporer adalah benarkah Dante membawa misi kenabian sebagaimana kisah nabi-nabi sebelumnya yang membawa petunjuk Ilahiyah? Dan benarkah ramalan yang diungkapkan Dante melalui Commedia? William Franke menjawab bahwa kritik yang bertubi-tubi dari seorang pembawa pesan kenabian tidak lebih dari asumsi liar dan tidak bertanggung jawab dari seorang penyair manusia. Ini merupakan cara yang diperlukan untuk mengkategorisasi mana pesan berupa wahyu divine dan mana hasil perenungan manusia semata. (William Franke, 2012: 12). Dari perdebatan kenabiannya tersebut, hingga kini The Divine Comedy selalu menarik untuk diperbincangkan, sehingga memudahkan seorang pengarang menciptakan latar akhirat Dante di dalam fiksinya.

Saat ini commedia Dante dipopulerkan melalui novel-novel modern dari berbagai genre. Novel-novel tersebut merujuk pada visi akhirat Dante, terutama visi tentang neraka.Pada tahun 1976, Larry Niven \& Jerry Pournelle menerbitkan novelnya yang berjudul Inferno. Novel tersebut menceritakan seorang penulis science-fiction terkenal, Carpentier, yang tiba-tiba tak sadarkan diri akibat meminum whisky di sebuah pesta launching bukunya. Saat terbangun dia sudah berada di suatu tempat yang diberi nama Infernoland. Ditemani sosok gempal dengan rambut di kepalanya sedikit jarang bernama Benito, sebagaimana Dante mendapatkan Virgil menyusuri neraka dalam commedia, Carpentier menemukan visi neraka sebagaimana yang digambarkan Dante. Perbedaannya, Inferno yang 
menjadi pengalaman Carpentier jauh lebih modern dibandingkan neraka medieval ala Dante Alighieri.

Disana Carpentier sudah menemukan planetarium dan banyak tuas listrik bertuliskan on dan off untuk menciptakan cahaya yang tidak alami. Mendapatkan informasi dari Benito tentang jalan keluar dari Infernoland, Carpentier harus melewati lorong dasar neraka untuk bisa keluar dan kembali ke kehidupannya yang normal. Belakangan dia baru menyadari sosok Benito yang menemaninya sepanjang petualangannya adalah Benito Mussolini, pemimpin Itali yang terkenal kejam saat Perang Dunia kedua. Novel ini mencoba mengubah visi neraka yang menakutkan menjadi fantasi teknologi dunia bawah yang mengagumkan. Namun, Novel Inferno karya Niven dan Pournelle ini hanya menampilkan visi Dante dan tidak menguak lebih jauh ke kedalaman teks Dante yang misterius dan kontraversi, bahkan novel ini terkesan menjauhi kecenderungan tersebut dan membenarkan teks Commedia.

Selain Inferno karya Larry Niven \& Jerry Pournelle, ada pula buku bergambar berjudul Jimbo's Inferno karya Gary Panter yang terbit pada tahun 1997. Buku yang mendapatkan penghargaan American Book Awards tahun 2007 ini menceritakan perjalanan Jimbo menelusuri gang-gang kecil Los Angeles. Dari pengembraannya, ia menyaksikan visi Inferno hadir di muka bumi. hell (red: neraka), menurutnya, mempunyai arti dan bunyi yang sama dengan mall, yang digambarkan sebagai pusat pengiklanan raksasa yang tak berotak, yang dinamainya Focky Bocky. Dari perjalanannya itu, ia menemukan bahwa visi neraka Dante malah tampak di sudut-sudut gang, dengan berbagai karakter anak- 
anak punk yang tersebar di sana. Ia menggambarkan metafora obat terlarang dengan naga raksasa yang menyemburkan nafas api. Di sana ada gadis-gadis cantik yang overdosis yang tenggelam oleh lautan nafas api sang naga, dan lakilaki gempal dengan perut yang sangat buncit tengelam dalam lumpur mereka tak lagi tak bisa berjalan akibat obesitas dan mabuk minuman keras. Gary Panter dalam fiksi bergambarnya tersebut di atas hanya memindahkan dan sedikit berinovasi mengenai visi neraka Dante ke permukaan kota Los Angeles. Meskipun tampak penghuni Inferno Jimbo adalah dari golongan punk yang dikenal sangat ekstrim mengusung gerakan postmodernisme ke dalam kehidupan sehari-harinya. Sayangnya, novel bergambar tersebut tidak menciptakan pergeseran logos yang berabad-abad dibenarkan masyarakat barat.

Novel international best-seller yang memperkenalkan neraka Dante selanjutnya adalah The Dante Club karya Matthew Pearl. Sejauh pengetahuan peneliti, novel ini menjadi novel pertama yang menggunakan teks-teks Dante sebagai clue dalam sebuah misteri pembunuhan berantai. Kisahnya diawali kematian seorang hakim agung Massachusetts bernama Artemus Healey. Kematiannya yang tragis, karena mayatnya ditemukan bekas hantaman keras di kepala dan dibiarkan kepalanya itu dikerumuni belatung dan lebah besar, membuat Holmes mencurigai bahwa kematian tersebut menyerupai hukuman neraka Dante, apalagi, ditemukan kematian yang lain seorang Pendeta Talbot yang kepala hingga perutnya tertancap di tanah dan kakinya terbakar persis dengan hukuman pem-bid'ah neraka Dante. Sedangkan, di tempat lain sekelompok penyair membuat suatu proyek memperkenalkan teks Dante ke 
Amerika dengan menerjemahkan The Divine Comedy ke dalam Bahasa Inggris. Namun, rentetan peristiwa pembunuhan yang terjadi tersebut malah menciptakan pandangan buruk tentang commedia di mata masyarakat Amerika.

Oleh karena itu, Holmes dan kawan-kawannya, dari pengalaman teksnya yang mendalam, berusaha membongkar teka-teki kematian misterius tersebut sebelum masyarakat menganalisanya. Seperti novel-novel sebelumnya teks The Divine Comedy, oleh Matthew, hanya dijadikan latar tanpa menggeser konstruksi logos yang dibangun Dante Alighieri. Adapun perdebatan-perdebatan di kalangan penyair dan professor yang tergabung dalam Dante Club hanya bergelut pada wilayah kepengarangan Dante dan bukan pada kedalaman teks The Divine Comedy.

Novel terakhir dan sekaligus menarik kembali perhatian dunia terhadap Dante dan The Divine Comedy adalah Inferno (2013) karya Dan Brown. Dan Brown, menurut Maslin (2013: 36), dikenal sebagai pengarang paling kontroversial di awal abad 21 setelah menerbitkan novel The Da Vinci Code pada tahun 2003 dan difilmkan pada tahun 2006. Setelah berhasil merebut perhatian pembacanya, novel Angel and Demon difilmkan pada tahun 2009, dan di tahun yang sama novel The Lost Symbol diterbitkan. Setelah The Lost Symbol (2009) terpajang di toko-toko buku, Menurut Rogak (2013: 235), pembacanya telah menaruh harapan bahwa novel selanjutnya yang mengisahkan petualangan Prof Robert Langdon itu bukan hanya merangkai thriller, traveling, dan sains ke dalam alur cerita tetapi juga memunculkan fakta-fakta historis yang terkadang bertolak belakang dengan keyakinan relijius agama-agama langit saat ini. Inilah yang 
membuat Dan Brown mendapat kritik pedas dari pemimpin-pemimpin agama di seluruh dunia.

Dari pemaparan di atas, Dan Brown melalui novel-novelnya cenderung memunculkan fakta-fakta historis alternatif untuk meruntuhkan atau mempersandingkannya dengan fakta sejarah yang telah diyakini oleh dunia selama berabad-abad. Salah satu contohnya pada novel Da Vinci Code (2003) Brown percaya, tentunya dalam teks, bahwa Magdalena adalah istri Yesus. Ini menyebabkan pastur-pastur konservatif mengecam novel The Da Vinci Code (2003) bahkan mengancam pengarang dan dituduh penganut neoliberal, pengagum teori konspirasi dan lain-lain. (Rogak, 2013: 165).

Novel Inferno (2013) sebagai sebuah reaksi terhadap teks The Divine Comedy, tentunya pengarang telah mempersiapkan strategi teks untuk menghadirkan negosiasi atas keras hati Dante Alighieri yang direpresentasikan melalui puisinya tersebut. Commedia, menurut Durling (1996: 4), menampilkan secara tegas seorang penyair yang keras kepala dan anti-negosiasi. Dante Alighieri, melalui puisinya, mendikotomi kebaikan dan kejahatan melalui interpretasinya sendiri terhadap Alkitab, dengan menjerumuskan lawan-lawan politik dan tokoh-tokoh yang berbeda ideologi ke dalam siksaan abadi di neraka.

Untuk mengeksplorasi sejauh apa novel Inferno menegosiasikan teks The Divine Comedy, peneliti menggunakan teori dekonstruksi yang dikembangkan oleh Jacques Derrida. Dekonstruksi merupakan strategi pembacaan teks dengan memperhatikan susunan hirarki dan oposisi biner agar tampak posisi pengarang 
dalam mendikte pembacanya (Booker, 1996: 75). Menentukan bangunan hirarki dalam teks dapat mempermudah pembaca dekonstruksi untuk mengamati polemik yang mempengaruhi penyair menuliskan puisi-puisinya. Selanjutnya, seorang pembaca dekonstruksi akan mengasosiasikan oposisi hirarki yang terdapat dalam teks dengan konteks si pembaca. Dalam kaitannya dengan penelitian ini, The Divine Comedy sebagai teks dan novel Inferno merepresentasikan konteks Dan Brown sebagai pembaca dekonstruksi puisi Dante Alighieri.

Dalam rentetan karya-karya populer, sebagaimana menurut Ida Rohadi (2012: 164) dekonstruksi tidak pernah menjadi tema utama atau dominan dalam fiksi populer disebabkan terminologi dan gayanya yang membingungkan, novel Inferno masih berada di jalur pop yang semangat penulisannya menyesuaikan selera, dan daya nalar pembacanya dengan mengutamakan kemasan ketegangan, traveling, dan informasi sains seperti yang dijelaskan sebelumnya. Oleh karena itu, penelitian ini tidak menguji secara keseluruhan teks Inferno apakah dekonstruktif atau tidak tetapi hanya mengambil deretan-deretan penting dalam teks yang dipandang berpotensi mendekonstruksi puisi The Divine Comedy.

\subsection{Rumusan Masalah}

Dari penjelasan tersebut di atas, dapat disusun rumusan masalah bahwa sebagai karya agung, teks The Divine Comedy menawarkan konsep logosentrisme, agar meyakinkan pembaca di setiap zaman. Oleh karena itu, penelitian ini berusaha menjawab bagaimana pengarang mengkonstruksi logos dalam puisi The Divine Comedy. 
Setelah menjawab pertanyaan di atas, teks tersebut selanjutnnya dipersandingkan dengan novel Inferno karya Dan Brown, teks yang mendekonstruksi Commedia. Dengan begitu penelitian ini akan menunjukkan apa saja konstruksi dari teks Commedia yang didekonstruksi oleh Dan Brown melalui novel Inferno, serta bagaimana strategi teksnya.

\subsection{Tujuan Penelitian}

Implikasi dari penelitian ini adalah untuk memberikan pemaparan mengenai makna-makna logos yang terdestruksi dari kumpulan puisi The Divine Comedy karya Dante Allighieri yang ditemukan di dalamnovel Inferno karya Dan Brown. Selain itu, penelitian ini juga bertujuan menemukan strategi serta gagasan pengarang dalam mendekonstruksi prosa The Divine Comedy karya Dante melalui pembacaan cermat terhadap novel Inferno.Adapun tujuan sekunder dari penelitian ini tidak lain adalah memperkenalkan cara baca dekonstruksi Derrida sebagai kajian sastra kepada masyarakat luas, khususnya masyarakat sastra. Diharapkan kemudian penelitian ini dapat memberikan sumbangan berarti terhadap perkembangan penelitian sastra.

\subsection{Tinjauan Pustaka}

Sejauh pengetahuan penulis, penelitian mengenai novel Inferno karya Dan Brown dari berbagai aspek dapat dikatakan nyaris belum ada yang melakukannya. Dugaan ini dapat diterima secara logis mengingat peluncuran novel ini masih terbilang baru yaitu 14 Mei 2013. Review mengenai novel ini pun belum begitu banyak, akan tetapi cetakan novel Inferno telah melampaui level satu juta copy di 
awal tiga bulan setelah peluncurannya. Peneliti memprediksi bahwa novel ini akan mengalami permintaan yang sangat besa tidak lebih dari tiga tahun setelah penerbitannya.

Adapun tinjauan pustaka dalam penelitian ini adalah penelitian-penelitian terkait objek material berupa novel-novel Dan Brown yang bertokoh sentral Professor Robert Langdon dan objek formal berupa teori Dekonstruksi yang diusung oleh Jacques Derrida. Friska Pujiyanti (2010) Dalam penelitiannya memanfaatkan teori strukturalisme model A.J Greimas sebagai landasan untuk menemukan oposisi biner bagi langkah kerja dekonstruksi, dan perspektif feminisme dekonstruksi digunakan sebagai pembacaan feminisme atas analisis dekonstruksi-menunjukkan dua sumbu pertentangan (oposisi biner) yaitu doxa dan orthodoxa. Hasil analisis dekonstruksi dengan pembacaan perspektif feminisme dekonstruksi menunjukkan adanya dekonstruksi terhadap dominasi laki-laki yang dilakukan oleh doxa. Dalam penelitiannya, posisi Magdalena yang dimitoskan sebagai seorang pelacur dalam kepercayaan umum Kristen, menjadi rentan akibat fakta-fakta yang dimunculkan teks The Da Vinci Code bahwa dia adalah istri Yesus. Terlebih lagi sistem gereja Sion sebaga sudut pandang teks adalah materanial dimana kepemimpinan (kepausan) diberikan kepada anak perempuan.

Pinto Anugrah (2012) Dalam tesisnya dibahas oposisi biner yang termuat di dalam naskah drama Dara Jingga karya Wisran Hadi. Pasangan oposisional tersebut terutama terlihat pada Tambo yang menjadi kitab bangsa Minangkabau. Tambo memuat kisah dan peristiwa-peristiwa ideal yang menjadikan rujukan 
hidup masyarakat Minangkabau. Sebagai makna ideal, masyarakat Minangkabau meyakini peristiwa-peristiwa yang ada dalam Tambo karena makna ideal itu sendiri merupakan puncak dan keinginan dan kesadaran untuk bergerak dengan nilai-nilai yang disepakati. Selain itu, Dara Jingga karya Wisran Hadi dianggap menggugat eidos. Namun penelitian tersebut menyatakan tidak ada pergeseran oposisi biner dalam Tambo di dalam naskah Wisran Hadi tersebut. Posisi alam asli dan alam tiruan yang dibangun dalam Tambo tidak mengalami negosiasi apalagi berasosiasi di dalam naskah Dara Jingga, hanya memotret ruang sosiokultur yang lebih kekinian mengenai masyarakat Minangkabau.

Sementara itu, Mashuri (1991) dalam jurnalnya yang membahas tentang novel Durga Umayi karya Y.B Mangunwijaya. Dalam penelitiannya dibahas tentang perayaan pembacaan dalam novel Durga Umayi karya Y.B. Mangunwijaya, Pendekatan menggunakan 'cara baca' dekonstruksi. Fokus kajiannya pada diskursus wayang yang cukup dominan dalam karya yang terbit pada 1991 ini. Ditemukan begitu banyak pembongkaran pada konstruksi wayang yang mapan dan terbukti dengan adanya banyaknya jejak teks yang dibaca kembali dengan perspektif tak tunggal, kontradiksi tokoh, pengaburan fakta-fiksi, serta pembalikan nilai-nilai oposisi biner lainnya. Konsepsi pengaburan dan pembalikan oposisi biner dalam novel ini diformulasikan menjadi semacam senyawa eksperimental sehingga terjadi decentering, peniadaan pusat (pusat menyebar).

Sedangkan Anton Sutandio (2003) membahas tentang karya-karya Stephen King dengan judul tesis Pembacaan Dekonstruktif dari 4 Novel karya Stephen 
King dalam Konteks Ideologi Rasisme dan anti-Rasisme. Ditemukan adanya representasi kelompok minoritas kulit hitam oleh King dan menunjukkan inkonsistensi penokohan, serta aspek-aspek yang muncul lewat pengungkapan ideologi rasisme dan anti-rasisme yang bekerja di dalamnya.

Dari tinjauan pustaka yang berobjek formal dekonstruksi di atas, penelitian ini berbeda dengan yang lain. Hal ini karena tesis ini lebih memfokuskan pada pembacaan dekonstruksi novel Inferno karya Dan Brown terhadap puisi karya Dante Alighieri "The Divine Comedy". Meskipun karya ini telah diteliti dari berbagai aspek, namun sejauh pengamatan peneliti, belum ada penelitian yang mencoba meneliti strategi teks novel Inferno dalam mendekonsruksi The Divine Comedy.

\subsection{Landasan Teori}

Sebagaimana dijelaskan di latar belakang, dekonstruksi merupakan strategi pembacaan teks dengan mengedepankan susunan hirarki simbol dan oposisi biner agar tampak posisi pengarang dalam mendikte pembacanya, setelah itu teks dibongkar dengan menselaraskan oposisi hirarkis, mengasosiasikannya dengan yang lain, sehingga teks menjadi tidak stabil dan menunda kebulatan maknanya. Pembacaan Dan Brown melalui novel-novel sebelumnya terbukti menegosiasikan oposisi di ruang-ruang spiritual seperti dipaparkan di latar belakang. Novel Inferno pun diharapkan mampu mereduksi hirarki yang termuat di dalam teks The Divine Comedy karya Dante Alighieri melalui alur dan konflik yang ada di dalamnya. 
Menurut Culler (1983) yang menyatakan bahwa hasil dekonstruksi tidak menawarkan teori yang lebih baik dari kebenaran, melainkan bekerja dalam dan sekitar kerangka diskursif yang ada, lalu dipertegas dengan mengatakan, dia tidak menawarkan dasar. Meskipun demikian, Dekonstruksi masih tidak dapat dilepas dari konstruksi (sistem) sebelumnya, khususnya strukturalisme (Faruk, 1994: 32). Oleh karena itu, pembahasan ini akan dimulai dari gerak pemikiran strukturalisme Saussure, yang diklaim Derrida sebagai pemikiran fonosentrisme.

\subsubsection{Dekonstruksi dan Kritik terhadap Strukturalisme}

Secara singkat, Saussure berpandangan bahwa ada kestabilan di balik kompleksitas penandaan di dalam sebuah bahasa. Kestabilan tersebut ia perkenalkan dengan nama langue. Langue mengatur pemaknaan tertentu yang dipakai untuk menunjukkan realitas (Fayyadl, 2005: 33). Pengaturan pemaknaan ini disebut dengan "tanda" (signification). Tanda terdiri atas dua komponen: (1) citra akustik (acoustic sense) yang disebut penanda (signifier); dan konsep (mental sense) yang disebut petanda.

Penanda merupakan kesan bunyi yang memateri dari bunyi mulut penutur, dan petanda sendiri merupakan konsep dari penanda yang dirasakan secara mental di dalam pikiran penutur. Hubungan antara penanda dan petanda tidaklah bersifat alamiah. Hubungan tersebut berasal dari kesepakatan-kesepakatan yang dibangun oleh masyarakat, atau bersifat konvensional. Korelasi antara penanda dan petanda dibangun tanpa alasan yang logis, hanya hubungan kebetulan dan arbitrer, atau semaunya. 
Penanda dan petanda di dalam bahasa, menurut Saussure (Sarup, 2008: 47), berhubungan seolah-olah keduanya adalah dua sisi dari mata uang yang tidak saling terpisahkan satu dengan yang lainnya. Dalam langue, tanpa salah satunya hanya akan menyebabkan hilangnya fungsi bahasa. Semisal tanpa citra mental, bunyi yang diproduksi hanya berupa igauan tanpa gagasan sama sekali, begitu pula sebaliknya, tanpa bunyi citra mental tidak akan pernah tersampaikan.

Melanjutkan penjelasan di atas, selain bersifat konvensional hubungan penanda-petanda juga bersifat tertutup. Tanda-tanda memiliki mekanismenya sendiri dalam mengatur makna agar tidak terjadi tumpang tindih. Mekanisme ini disebut diferensi atau difference. Diferensi merupakan sebuah kemungkinan bahwa masing-masing tanda bersifat eksklusif. Saussure meyakini tanpa kehadiran difference, penutur tidak akan sanggup menjelaskan gagasan yang ingin ia sampaikan karena baik penutur maupun pendengar masing-masing tidak menginginkan atau menghindari adanya gagasan yang maknanya mendua atau absurd.

Ciri yang paling utama dari pemikiran Saussure-yang juga sebagai pintu memasuki khasanah makna dari teori dekonstruksi-adalah dengan memusatkan perhatian pada bunyi dan mengabaikan teks. Ada dua alasan mengapa Saussure berpendapat demikian; Pertama, langue terus menerus berkembang; dan yang kedua karena bunyi dapat menampilkan penutur sebagai subjek yang utuh dalam kegiatan berbahasa. Saussure menafikkan teks dengan menganggap bahwa teks hanya representasi dari tuturan. Tuturan adalah primer dan teks atau aksara adalah bahasa sekunder. Beberapa sumber yang peneliti temukan mengatakan bahwa 
Ferdinand de Saussure tidak menerbitkan buku atau jurnal tentang Cours de Linguistique General, tetapi pemikiran ini terbukukan dari inisiatif mahasiswamahasiswanya mengumpulkan catatan-catatan mereka dan kertas-kertas yang terselip di bawah podium Saussure saat berceramah. Ini dilakukan Saussure bukan hanya sekadar menjaga ke-konsisten-an pemikirannya pada keutamaan phone tetapi juga merupakan bentuk ketakutannya yang menganggap bahasa tertulis adalah ancaman terhadap sistem internal langue.

\subsubsection{Ketidak-Stabilan Teks}

Dengan adanya tatanan rapi yang dibangun oleh Saussure dalam ilmu linguistik tersebut, problem struktur tentunya belumlah selesai. Struktur, dalam hal ini bahasa, masih ditemukan celah-celah rapuh yang pergeserannya dapat meruntuhkan struktur tersebut. Pemikir-pemikir postrukturalisme mengorek kembali celah-celah yang terabaikan itu untuk menguak nilai-nilai yang tak terjamah di ruang keilmuan yang baru. Sebagai sebuah pemikiran, postrukturalisme berbeda dengan strukturalisme. Pemikiran ini tidak menekankan pada konsep yang terstruktur, tetapi, menurut Young, mengimplikasikan rekaan (fiction) mengenai suatu perkembangan karena ia lebih melibatkan suatu pergesaran atau pemelesetan (displacement), ia lebih merupakan sebuah interogasi terhadap metode-metode dan asumsi-asumsi strukturalisme, mentransformasikan konsep-strukturalis dengan mengubahnya menjadi bertentangan satu sama lain (Faruk, 2012: 177). 
Implikasi pandangan tersebut memberikan ciri yang sepadan dengan sentilan yang dilakukan pemikir sebelumnya, Nietzche, mengenai bahasa dengan mengatakan bahwa kita sesunggguhnya percaya bahwa kita mengenal segala sesuatu ketika kita tengah membicarakan tentang pepohonan, warna-warna, salju, dan bebungaan; namun pada saat yang sama kita tidak mengetahuinya kecuali hanya berupa metafora tentang benda-benda tersebut (Brooker 1996: 55). Hal ini mengisyaratkan bahwa persoalan struktur bahasa tidaklah selesai begitu saja dengan menghadirkan penutur karena selalu saja ada makna yang belum tuntas dalam mematerikan dan atau menangkap suatu gagasan. Metafora merupakan gagasan yang penting di dalam dekonstruksi Jacques Derrida, namun sebelum memasuki pemaparan Derrida tentang metafora, Ferdinand de Saussure sendiri telah memberikan sinyal bagi metafora untuk menghancurkan tatanan yang telah dibangunnya, yaitu tanda (signification).

Seperti dijelaskan sebelumnya, Saussure yakin bahwa ada dua substansi yang membangun signification, yakni penanda (signifier) dan petanda (signfied). Dijelaskan pula sebelumnya, keduanya seperti sepasang sisi mata uang yang tidak saling terpisahkan, tetapi, bagi Derrida, pada dasarnya penanda tidaklah membutuhkan petanda untuk membentuk suatu tanda, begitu pula sebaliknya. Keduanya tidak seperti dua sisi keping mata uang sebagaimana pemaparan Saussure di atas, bagaimanapun keduanya masih memiliki jarak, sehingga pada akhirnya petanda dan penanda tidak lagi berada pada sebuah dikotomi khusus yang membedakan keduanya. 
Contoh sederhana diilustrasikan oleh Derrida adalah saat seseorang ingin mencari pengertian suatu kata (wujud dari penanda) di dalam kamus, yang ditemukannya hanyalah kumpulan penanda yang berantai satu dengan yang lain, berupa interaksi penanda yang kompleks. Ketika orang tersebut ingin lagi mengetahui penanda dari petanda yang diharapkannya, yang didapatinya hanya relasi penanda yang kurang lebih kompleksitasnya sama. Makna tidak serta-merta hadir di dalam tanda. Makna tersebar atau terserak di sepanjang rantai penanda. Ia tidak dapat ditangkap dengan mudah, dan ia tidak pernah sepenuhnya hadir dalam satu tanda yang mana saja, tetapi lebih berupa kilasan yang terus-menerus dari kehadiran dan ketiadaan secara bersamaan.

Membaca teks pada akhirnya lebih mirip melacak proses terus menerus, sama halnya menghitung kerlap-kerlip manik-manik penanda yang berjejer tanpa batas. Ini dapat disimpulkan bahwa dengan membaca sebuah teks berarti melakukan upaya penundaan terhadap makna. Makna akan selalu tertahan dan yang baru akan datang. Satu penanda mengantar pemaknaan ke penanda yang lain, lalu meloncat lagi ke penanda yang lain. Makna sebelumnya dimodifikasi oleh makna sesudahnya. meskipun teks tersebut telah berakhir, proses bahasa dan pemaknaan belumlah habis.

Dari uraian tersebut, dapat digambarkan bahwa bahasa merupakan masalah yang tidaklah stabil jika dibandingkan dengan pendapat strukturalis klasik, meskipun Saussure sendiri mengakui bahwa bahasa, yang ditelitinya, bukanlah persoalan substansi tetapi bentuk (Fayyadl, 1995: 38). Bahasa bukannya berupa struktur yang terdefinisi dengan baik dan ditandai dengan jelas yang 
mengandung unit-unit simetris berisi penanda dan petanda, tetapi mirip jaringjaring.

Setelah meremukkan struktur tanda yang dibangun oleh Saussure, Derrida mencoba merambah lebih jauh dengan mempartanyakan unsur penting yang membentuk identitas tanda, yaitu difference. Selain berfungsi memperjelas arti masing-masing tanda, diferensi tanda-tanda juga berfungsi memperlihatkan sistem relasi yang unik dalam bahasa. Bahasa, menurut Saussure, selalu bergerak dalam relasi tanda yang tak ada ujung pangkalnya. Namun hanya melalui diferensi, relasi itu dimungkinkan. Diferensi menciptakan identitas pada setiap tanda.

Derrida bukan sekedar memandang diferensi sebagai identitas tanda. Ia juga melihat potensi diferensi sebagai sebuah oposisi biner. Oposisi biner menciptakan kategori-kategori terhadap tanda dengan merujuk pada penutur/subjek. Diferensi menilai lisan/tutur lebih baik daripada tulisan; langue lebih baik daripada parole dan seterusnya. Saussure terlalu menekankan bahasa pada phone, sehingga Derrida menilai Saussure sebagai seorang yang fonosentris.

Jika ini diturunkan ke dalam filsafat barat, maka oposisi biner akan tampak begitu ekstrim: "yang ada" lebih mulia daripada "yang absen"; jiwa berada di atas badan; benar lebih baik daripada salah; dan sebagainya. Hal ini menciptakan polemik terhadap bahasa. Ada arah terpusat yang tanpa sengaja ditampilkan oleh bahasa. Derrida menyebutnya sebagai logosentris. Jauh sebelum Derrida menuding Saussure sebagai pemuja logos, Nietzche - pemikir sezaman denga Saussure - telah mengutarakan perlawanannya terhadap para penganut logosentris 
dengan mengatakan semangat mau mencari nilai-nilai adalah kebiasaan kuno. Ia lebih tertarik dengan mencari cara untuk berkata "Ya" pada dunia yang adalah chaos dan nihil, yang tidak mengandung kebenaran mutlak atau tata dunia moral (Sunardi, 1996: 48).

Jika merujuk pada pemikiran Nietzche di atas, maka bukanlah sesuatu yang baru jika mengatakan bahwa bahasa adalah sistem yang tidak stabil. Penutur tak lagi menjadi sumber yang tepat mengungkapkan makna karena bahasa merupakan sesuatu yang dari dirinya orang tersebut berasal, bukan sebagai sebuah alat yang ia gunakan. Seluruh gagasan bahwa diri seseorang merupakan sebuah entitas yang stabil dan terpadu, kata Faruk, adalah fiksi (Faruk, 2012: 210).

Dampak dari pemikiran bergaya logosentris bukan hanya menciptakan pemusatan makna kepada penutur atau mencari misteri asal-usul penulisan tersebut, tetapi memenjara bahasa ke dalam nilai-nilai yang sifatnya emanen. Emanasi bahasa terjadi akibat pemusatan yang bersifat vertikal. Pemikir-pemikir, diklaim Derrida, yang masuk di dalam kategori logosentris tak lebih hanya bernostalgia dengan pemikiran platonik yang memprioritaskan kesatuan ketimbang keragaman. Falsafah agama samawi (Yude-christian) yang monoteis juga telah mempengaruhi pemusatan tersebut. Ketunggalan pusat merupakan ciri yang paling utama dari strukturalisme.

Dapat dianalogikan bahwa untuk menggambarkan emanasi itu ibarat sebuah cahaya senter yang menyinari ruang gelap-gulita, cahaya diibaratkan struktur tanda yang tersebar di dalam ruang, dan senter sebagai logos. Disini cara 
kerja Logos - Roh Absolut yang menurut Hegel - pun dapat tampak begitu nyata. Sebagai pusat, senter berada di luar dari rangkaian cahaya atau struktur tanda. Jika ditempatkan beberapa benda di titik-titik yang berbeda di sekitar cahaya tersebut, maka benda-benda yang ditempatkan di titik-titik tersebut akan tampak berbeda dalam mendapatkan intensitas cahaya. Titik yang paling dekat mendapatkan cahaya yang lebih besar, sebaliknya yang terjauh mendapatkan citra cahaya yang lebih sedikit. Begitupun halnya dengan struktur tanda, hirarki selalu muncul di dalam butiran-butiran tanda.

\subsubsection{Differance}

Dengan memperhatikan analogi di atas, maka dapat disimpulkan bahwa derajat tanda selalu ada di dalam setiap kehadirannya. Untuk membongkar emanen tanda tersebut, Derrida memperkenalkan istilah differance sebagai bentuk perlawanan terhadap difference Saussure yang berkelas-kelas. Secara etimologi Differance bisa berakar dari kata to differ yang berarti membedakan, dan to defer yang berarti menangguhkan atau menunda. Dari dua akar kata ini saja sudah tergambar sebuah parodi bagaimana Derrida mengacak-acak pakem diferensi makna yang kaku itu dengan menciptakan istilah yang definisinya masih ambivalen. Differance melengkapi permainan Derrida dalam mencairkan kompleksitas tanda di dalam teks.

Differance merupakan strategi untuk memperlihatkan perbedaanperbedaan yang implisit sekaligus menyodorkan tantangan terhadap totalitas makna dalam teks (Fayyadl, 2005: 111). Perbedaan-perbedaan tersebut tentunya 
akan menyingkirkan asumsi-asumsi klasik tentang keberadaan tanda yang bukan saja terkungkung oleh penjara makna tetapi juga berasal dari anak tangga sebuah gradasi logos. Identitas tanda tidak lagi mengalami emanasi.

Sebelum Derrida memperkenalkan differance, filsafat berada pada posisi yang rumit di dalam mengejahwantahkan totalitas makna karena mereka mengikatkan diri pada kata-kata yang utama seperti keberadaan, esensi, kebenaran, atau realitas yang akan menjadi fondasi dari seluruh pikiran, bahasa, dan pengalamannya (Faruk, 2012: 212). Ketidak-terlibatan logos juga, di dalam rangkaian tanda, menjadi perhatian Derrida. Ia yakin bahwa kebenaran tidak bisa ditemukan di luar sistem diferensial yang membentuk bahasa; kebenaran tidak tampil dalam ruang hampa, melainkan dirajut dari relasi-relasi rumit yang sambung menyambung di dalam tubuh bahasa (Fayyadl, 2006: 76).

Ketika logos ditarik ke dalam teks atau sastra, hirarki yang terbangun di dalam tanda secara otomatis mengalami pergeseran yang tidak ada habisnya. Aspek diferensial, dan oposisi yang hirarkis menyebar dan tanda bersifat diseminatif, karena tanda-tanda yang termuat dalam sebuah teks menyebar dan berhubungan denganteks-teks lain. Dalam rangkaian intertekstualitas, tidak ada lagi kebenaran atau makna yang otonom. Kebenaran dibentuk dari teks, ditemukan dalam teks, diinversi dan direkayasa dalam teks (Fayyadl, 2006: 77).

Derrida selanjutnya mengaburkan logos dengan mengatakan:

Dunia adalah teks. Tidak ada sesuatu yang berdiri di belakangnya... Konsep "ada", "kesadaran", "kehadiran", dan "diri" hanyalah ciptaan belaka, rekaan, dan berupa sulaman penafsiran. Fungsi- 
fungsi tak memiliki fakta. Akibat dari bahasa bukanlah sebab... teks (sastra) bukanlah sebuah objek yang utuh bukan pula objek yang otonom, tetapi merupakan serentetan relasi dengan teks-teks yang lain... genealogi dari teks sepantasnya adalah sebuah rangkaian-rangkaian yang tidak utuh. Oleh karena itu, tradisi merupakan satu bentuk kekacauan.Setiap teks adalah interteks. (Brooker, 1996: 59).

Dengan begitu pengaruh logos tidak lagi mengekslusi makna teks. Logos terjebak di tengah jaring-jaring rajutan tanda yang tersebar kemana-mana di dalam teks, sehingga tidak ada lagi yang perlu diragukan bahwa semuanya hanya ada di dalam teks. There is nothing outside the text (Johnson, 1981: 158).

Penyebaran logos di dalam teks memberikan dampak pada penafsiran yang radikal terhadap teks tersebut, sebagaimana telah disebutkan di atas bahwa Kesadaran, Diri, dan Kehadiran yang merupakan representasi logos tidak lebih merupakan interpretasi dominan yang membungkam suara-suara subordinat. Dalam pada itu, ketika logos, yang selama ini menjaga jarak, ditarik kembali ke dalam teks, tentunya suara-suara yang terbungkam atau dalam hal ini berbagai kemungkinan interpretasi akan muncul di permukaan.

\subsubsection{Negosiasi Oposisi Biner}

Sebagaimana dijelaskan sebelumnya, totalitas makna, menurut Nietszche, hanya sanggup direfleksi melalui metafora. Hal ini disebabkan karena penanda hanya mampu dijelaskan secara metaforik. Faruk menambahkan bahwa pada dasarnya bahasa juga bekerja dengan mentransfer atau memindahkan satu realitas ke realitas yang lain sehingga bersifat metaforik (Faruk, 2012: 215). Metafora adalah sebuah pemaknaan yang bersifat paradoksial karena, bagi Derrida, teks 
yang tidak paradoks dianalogikan secara jenaka sebagai seorang pecinta yang tak memiliki hasrat. Berbicara di ruang paradoksial, maka ambivalensi yang berupa permainan kata atau parodi merupakan fokus strategi teks dalam mempermainkan emosi makna. Oleh karena itu, karya sastra dipandang mampu mengoyak teks yang telah memapankan makna dan hirarkinya.

Setelah penjelasan yang panjang ini, pertanyaan selanjutnya bagaimana wujud hirarki itu di dalam teks. Telah dijelaskan sebelumnya, bahwa pemikiran barat tidak lepas dari filsafat klasik, dalam hal ini Aristoteles, mengenai prinsip non-kontradiksi (Booker, 1996: 59). Prinsip non-kontradiksi menyatakan bahwa suatu benda atau apapun itu tidak bisa mencirikan sesuatu sekaligus tidak mencirikan sesuatu tersebut. Prinsip ini membimbing Derrida pada logika "eitheror" yang implikasinya mengisyaratkan adanya pemikiran dualistik. Logika tersebut juga menciptakan pembelahan segala aspek kehidupan menjadi rentetan pasangan yang kategorinya berlawanan. Ini merupakan sentral dari seluruh pemikiran barat.

Bagi Derrida, pikiran yang dualistik ini hanya akan memiskinkan dan memenjarakan teks ke dalam nilai-nilai tertentu. Hirarki bisa mewujud dari dualistik tersebut, menciptakan dua kutub yang berlawanan yang disebabkan logosentrisme, seperti yang dikemukakan pembahasan sebelumnya. Kedua kutub ini menunjukkan pertentangan yang radikal. Satu kutub mendominasi yang lain, Seperti antara "mulia"dan "hina". Oposisi berpasangan ini bukan hanya tidak bisa saling bertukar makna, tetapi juga tak bisa bertukar nilai. Ini membuktikan masing-masing oposisi memiliki keterbutuhan satu dengan yang lain. 
Derrida memberi catatan penting bahwa konsepnya tidak membawa pada pemahaman yang nihliistik. Differance, rekaan Derrida, hadir untuk menunda hirarki di dalam teks, tanpa bermaksud menghilangkan nilainya. Differance menginterogasi "mulia" dengan mempertanyakan kembali ke-mulia-nnya atau dengan menelusuri nilai-nilai mulia di balik "hina". Seterusnya akan seperti itu, sehingga menciptakan citra paradoksial di dalam teks atau sastra.

Citra yang paradoks ini secara terang-terangan juga digambarkan di dalam Novel Inferno karya Dan Brown. Robert Langdon, di awal ceritanya, menganggap bahwa penafsiran Dokter Zobrist-tokoh antagonis di dalam novel Infernoterhadap puisi-puisi di dalam komedi Dante telah menyimpang dan meretakkan nilai luhur yang dicita-citakan Dante untuk zamannya. Zobrist memaknai kutipan puisi Dante, yang mengatakan the darkest places in hell are reserved for those who maintain their neutrality in times of moral crisis [kerak neraka terdalam dipersiapkan bagi mereka yang kerap bersikap netral saat krisis moral terjadi], sebagai pijakan untuk menerapkan kebenaran yang ia pahami dengan berkeinginan membunuh sepertiga manusia yang ada di seluruh dunia secara acak demi kelangsungan hidup generasi selanjutnya.

Sebagai seorang dokter, ia menyadari bahwa dengan membebaskan manusia dari penyakit berarti ia tidak memberikan kesempatan generasi selanjutnya untuk hidup layak. Menurutnya, peradaban yang sehat hanya akan menimbulkan populasi yang berlipat-lipat ganda. Ketika populasi sudah melampaui batas, maka, menurutnya, yang ada hanya akan menghasilkan generasi yang kelaparan, bermoral buruk, kejahatan dimana-mana, dan yang tersadis, 
mengutip pernyataan Machiavelli (Brown, 2013: 104), Ia tidak membiarkan hal itu terjadi, demi kelestarian species manusia di alam semesta ini. Namun, akhirnya sang tokoh sentral, Robert Langdon, meminta kepada pemimpin WHO untuk membicarakan kembali ide gila Zobrist tersebut di forum paripurna WHO karena ini menyangkut kemaslahatan manusia di seluruh dunia.

Interpretasi terhadap The Divine Comedy yang berubah-ubah dan saling menindih di dalam novel Inferno bukan hanya sekadar bermain di ranah keambigu-an penafsiran tetapi juga sebagai bagian dari strategi pengarang dalam menciptakan fiksi populer ala Amerika, sebagaimana diutarakan Ida Rochani:

Cerita-cerita laga... Amerika... menemukan kekaburan dalam oposisi biner apabila menyangkut oposisi antara protagonis dan antagonis; atau dengan kata lain gap antara tokoh jahat dan hero tidak signifikan sehingga disimpulkannya bahwa kategori yang beroposisi ini tidak konsisten dan kejelasan oposisi biner tergantung pada genre fiksi populer. (2011: 152)

Tokoh sentral dalam novel Inferno Robert Langdon bisa saja di dalam separuh aksinya adalah aksi yang tidak heroik atau jahat, begitu juga sebaliknya, tokoh jahat di dalam novel Inferno, Dr. Sobrizt, pada aksi tertentu, mungkin saja dinilai tengah melakukan tindakan yang heroik. Oleh karena itu, mengingat dominan konflik novel ini ditarik dari penafsiran kutipan demi kutipan puisi Dante Alighieri, dan tersebab oposisi protagonis dan antagonis yang tidak konsisten, maka novel Inferno dapat dikatakan telah membuka ruang bagi penafsiran radikal terhadap Divine Comedy karya Dante Alighieri.

Pada akhirnya, pemikiran Derrida menyumbangkan sebuah metode membaca cermat sebuah teks. Pembacaan cermat dekonstruktif itu, sesudah 
menginterogasi teksnya, menghancurkan pertahanannya, dan menunjukkan bahwa seperangkat oposisi berpasangan ditemukan di dalamnya. Oposisi itu tersusun secara hirarkis dengan menempatkan salah satu pasang sebagai yang istimewa. Pembaca dekonstruksi bahwa identitas yang istimewa itu tergantung pada pengekslusiannya atas yang lain dan menunjukkan bahwa keutamaan justru terletak pada yang justru disubordinasikan (Faruk, 2012: 217).

Dengan memunculkan kemungkinan makna yang tersubordinasi, Novel Inferno telah melakukan sebuah pembacaan kritis melalui puisi-puisi yang termuat di dalam The Divine Comedy karya Dante Alighieri mengenai kehidupan dan kebutuhan manusia kekinian. Sebagaimana Derrida telah mengisyaratkan diawal bahwa kosmik/konteks jauh lebih utama dari sekedar menghadirkan Sang Pemilik Sabda. Mengidentifikasi strategi narasi, alur dan motivasi tokoh-tokoh di dalam di novel ini, melalui kacamata dekonstruksi, dapat menguak kecakapan Brown yang mengagumkan yang belum terpikirkan pembaca biasa bahkan untuk pecinta karya-karya Dan Brown.

\subsection{Hipotesis}

Perlu dipahami, sebagai bentuk kerja analisis tesis ini juga memiliki jawaban sementara terhadap permasalahan yang berhubungan dengan landasan teori di atas. Novel yang berjudul Inferno karya Dan Brown membangun pembacaan kritis terhadap puisi Dante Alighieri di dalam kumpulannya yang berjudul The Divine Comedy, disebabkan novel tersebut merepresentasikan konteks. Teks-teks Commedia dalam novel ini banyak berfungsi sebagai clue, 
objek travelling, informasi, dan nasehat-nasehat. Teks dan simbol berpotensi menyebar dan mengalami pergeseran Pusat bahkan menciptakan pusat-pusat yang lain sepanjang proses pembacaannya melalui novel. Hal ini kemudian dapat ditarik suatu asumsi sementara. Peneliti berasumsi bahwa semakin teks The Divine Comedy berasosiasi dalam novel Inferno semakin teks tersebut terdekonstruksi.

Adapun karya-karya Dan Brown lainnya seperti Angel and Demon, Digital Fortress, The Da Vinci Code, Deception Point, dan The Lost Symbol, serta puisipuisi di dalam The Divine Comedy karya Dante Alighieri merupakan variabelvariabel pendukung yang juga tidak kalah pentingnya di dalam penyusunan penelitian ini.

\subsection{Metode Penelitian}

Untuk membuktikan kebenaran hipotesis di atas. Penelitian ini menggunakan teori post-strukturalisme Dekonstruksi. Merujuk pada pernyataan Jacques Derrida every text is intertext, maka peneliti mengumpulkan dan mengkolaborasikan kutipan-kutipan atau interpretasi yang ada di dalam novel Inferno karya Dan Brown terhadap kumpulan puisi The Divine Comedy karya Dante Alighieri. Hal ini dipandang penting bagi peneliti untuk menemukan sejauh mana novel Inferno mengeksplorasi teks The Divine Comedy dalam menguak kebenaran-kebenaran sebelum logos $\quad$ - sebagaimana teori dekonstruksi menjelaskan pada sub-bab sebelumnya. 
Adapun teknik dekonstruksi yang digunakan dalam menganalisis logos puisi-puisi Dante yang terdapat di dalam Novel Inferno karya Dan Brown adalah dengan melakukan pembacaan cermat terhadap kompleksitas interpretasi puisipuisi tersebut melalui konflik-konflik, narasi, dan karakter-karakter serta latar belakang masing-masing tokoh yang diciptakan oleh pengarang. Pertama-tama, teks The Divine Comedy disusun berdasarkan struktur hirarkinya. Dari penyusunan demikian dapat mengungkap keistimewaan yang dibangun secara sistemik dan sekaligus trace dalam teks. Langkah kedua, Novel Inferno karya Dan Brown, sebagai representasi konteks kekinian dalam membaca Commedia, dipersinggungkan dengn The Divine Comedy. Mendekonstruksi suatu oposisi, Menurut Culler, adalah membalikkan suatu hirarki. Akan tetapi, aktivitas itu baru pada tahap pertama. Pada tahap berikutnya, pembalikan dilakukan terhadap keseluruhan yang di dalamnya oposisi itu menjadi bagiannya. Hanya dengan syarat itulah, dekonstruksi dapat memberikan alat untuk menembus oposisioposisi yang dikritiknya yang juga merupakan lapangan kekuatan non-diskursif (Manshuri, 2013). Oleh karena itu, persinggungan ini berlanjut dengan memperhatikan kembali oposisi atau gradasi hirarkis yang dibangun secara sistematis di dalam teks commedia.

Langkah selanjutnya, dengan melakukan pembacaan cermat teks Inferno dalam melakukan pemlesetan terhadap simbol-sombol yang terdapat dalam Commedia. Peneliti, selanjutnya melalui pembacaan cermat, memperhatikan oposisi hirarkis tersebut menghancurkan pertahanannya, berasosiasi, melakukan 
pembalikan, dan bernegosiasi satu dengan yang lain melalui narasi teks Inferno. Langkah ke empat, Kesimpulan ditarik berdasarkan data-data yang dianalisis.

Untuk meneliti teks awal, mengingat peneliti memiliki keterbatasan dalam memahami bahasa Itali yang merupakan bahasa asal The Divine Comedy, dalam pada itu digunakan terjemahan commedia berbahasa Inggris Henry F Cary. Henry F. Cary merupakan penerjemah sekaligus peneliti Inggris pertama yang mengkaji secara akademik tentang The Divine Comedy dan Dante. Buah pikirannya tentang The Divine Comedy menjadi rujukan peneliti-peneliti Inggris dan Amerika setelahnya, Pemilihan terjemahan tentunya memberikan dampak dalam analisis ini, namun peneliti berusaha semaksimal mungkin untuk mengeksplorasi pemahaman yang paling mendekati teks asli La Divina commedia.

\subsection{Sistematika Penyajian}

Sistematika penyajian penelitian ini terdiri dari empat bab. Bab I merupakan bab pendahuluan terdiri atas latar belakang, rumusan masalah, kerangka teori, dan metode penelitian. Bab II berjudul Dialog Dengan Logos, diuraikan strategi konstruktsi logosentrisme puisi The Divine Comedy karya Dante Alighieri. Bab III Dekonstruksi dalam novel Inferno, diuraikan pembacaan dekonstruksi terhadap Commedia Dante Alighieri. Hasil kesimpulan diuraikan di bab IV. 


\section{BAB II}

\section{DIALOG DENGAN SANG LOGOS}

Menelusuri sistem logos dalam The Divine Comedy tidak lepas dari pembahasan kondisi mental Dante Alighieri, yang meliputi aspek kesejarahan, perjuangan hidup, dan konsep religiusitas dan keilmuan yang berkembang dari abad ke-12 hingga awal abad ke 14. Pada subbab berikut ini dibahas tentang potret sejarah akhir era medieval di dunia yang mempengaruhi penulisan The Divine Comedy, latar belakang Dante, keluarga, dan Beatrice kekasihnya, serta sikap politiknya yang sangat mempengaruhi kehidupan Dante hingga menjadi seorang exile.

\subsection{Commedia sebagai Historiografi}

Menurut Grandgeent (Elliot, 1980: 4) The Divine Comedy merupakan autobiografi Dante. Dalam penelitian lebih lanjut, menurut Teresa de Lerutis (1990: 24) menyebutkan bahwa Comedia adalah autobiomitografi dari Dante Alighieri. Oleh karena itu, merujuk pada pemikiran kedua peneliti tersebut, maka penyusunan kronologi peristiwa abad ke-12 hingga abad ke-14 ini banyak didasarkan pada proyeksi teks dari puisi lirik The Divine Comedy.

\subsubsection{Akhir Era Medieval; Sengketa Guelf dan Ghibelline}

Menurut Durling, The Divine Comedy berisi detail komentar Dante terhadap situasi politik, ekonomi, dan sosial-religius yang ditangkap pada masa hidupnya (Durling, 1996: 3). Commedia Dante Alighieri tidak terlepas dari persoalan politik global yang mempengaruhi negeri terutama kota kecintaannya, Florence. Gagasan politik dan gerakannya diselipkan di banyak kidung puisi The 
Divine Comedy. Tak ayal banyak sejarawan menjadikan Commedia sebagai referensi penting dalam memetakan gambaran sejarah Italia dan Eropa dalam skala yang lebih besar.

Pada abad ke-13, Kota Florence adalah sebuah negara kota yang sedang merangkak cepat menuju kemajuan yang pesat. Kota ini mengembangkan kekuatan politik dan ekonomi sedikit lebih leluasa dibandingkan kota-kota yang lain. Hal ini disebabkan posisi kota Florence berada jauh dari Konstantinopel dan Inggris yang sedang bangkit menjadi kekuatan yang menakutkan di Eropa pada saat itu.

Sebagai kota yang mengembangkan pengaruhnya, Florence tentu tidak pernah lepas dari pengamatan dan perebutan peradaban-peradaban mapan di sekelilingnya. Oleh karena itu, pemimpin-pemimpin Florence di satu sisi berusaha melakukan pendekatan diplomatik terhadap kerajaan-kerajaan yang lain seperti Roma, Perancis, dan Inggris, namun, di sisi lain berusaha mematikan kekuatankekuatan politik dari dalam negeri yang mencoba menjatuhkan posisinya. Di Florence sendiri, pada saat itu, terdapat dua faksi terkuat yang silih berganti memimpin Florance dan berperang satu sama lain, bersaing mendapatkan posisi pucuk kepimimpinan di kota tersebut, yaitu Guelf dan Ghibelline. Perselisihan ini menciptakan kegelisahan yang mendalam bagi Dante tentang kotanya. Dia menyebut Florance dengan dela citta partita (baca: the divided city).

Nomore he said, and I my speech resumed:

"Ciacco! Thy dire affliction grieves me much, Even to tears. But tell me, if thou know'st, What shall at length befall the citizens Of the divided city; whether any Just one inhabit there: and tell the cause, 
Whence jarring Discord hath assail'd it thus"... (Inferno 6. 26)

[dia tak berkata-kata lagi, dan aku menjawab "Ciaccio, penderitaan yang engkau rasakan ini membuatku sangat sedih bahkan sampai meneteskan air mata. Tapi ceritakan padaku, apakah kau tahu apa yang akan menyengsarakan rakyat kota terbelah itu. Apakah dari beberapa (faksi) yang ada, hanya sekelompok (faksi) saja bisa menghuninya; dan beritahu aku akar pecahnya perselisihan yang menghantam (kota) itu”].

Guelf dan Ghibellini awalnya adalah dua faksi politik yang mendapat dukungan kuat hingga ke akar rumput di tengah masyarakat Itali dan sebagian besar wilayah lain di Eropa. Guelf adalah partai yang menginginkan kekuasaan dan pemusatan kepemimpinan Romawi yang seluas-luasnya pada Paus, sedangkan Ghibellini merupakan partai yang memperkuat semangat tradisi kerajaan Romawi dengan berpihak pada kekaisaran Romawi. Kedua faksi ini muncul dan bertikai sekitar tahun 1150-an, beberapa saat setelah dibai'atnya Frederick Barbarosa sebagai Kaisar Romawi. Kaisar Frederick membutuhkan dukungan rakyat Itali karena merasa setiap gerak-geriknya mendapatkan kritik dan kecaman dari pihak gereja, namun di sisi lain ia membutuhkan gereja sebagai kekuatan kultural untuk memperkuat pengaruhnya, seperti yang dilakukan Kaisar Justanian nenek moyangnya. Melalui faksi Ghibellini, ia mengumpulkan kaum tradisionalis Romawi dan melemparkan isu bahwa Gereja tidak tahu berterima kasih kepada Kaisar Roma terdahulu, kaisar Constantine, yang memberikan kesempatan, perlindungan, dan kebebasan menyebarkan agama Kristen di daratan Eropa. (Durling 1996: 4). Sedangkan kaum Guelf menuntut kepada kaisar agar Itali segera menjadi sebuah negara republik. Negara yang diidealkan Plato. Sebuah negara yang didukung oleh rakyat, dengan sistem yang melibatkan rakyat sebagai pengawas dan penentu kebijakan sebagaimana sistem negara yang 
modern, serta menghentikan sistem monarkhi yang tidak lagi berpihak pada rakyat.

Seiring berjalannnya waktu, dua kubu ini menjadi dua kelompok keluarga. Di Florance sendiri, seorang bayi dari keluarga Guelf secara otomatis akan berjuang demi Guelf seumur hidupnya, begitu juga sebaliknya. Selama puluhan tahun Keluarga Guelf menguasai Florance dan menyingkirkan kekuatan politik Ghibellini. Wilayah-wilayah yang didominasi Guelf di Italia pada abad ke-13 meliputi wilayah di antaranya Bologna, Florance, dan Perugia. Ghibellini meliputi wilayah Mantua, dan Pisa. Sedangkan wilayah netral meliputi Padua dan Sienna. Wilayah-wilayah tersebut sering muncul dan diceritakan di dalam The Divine Comedy.

Pada tahun 1215, Dua kubu yang berseteru memperebutkan dominasi politik dan ekonomi di Florance ini berupaya untuk berdamai dengan menikahkan putra-putri mereka. Di luar dari perkiraan ternyata pernikahan politik itu hanya menghasilkan konflik berdarah yang jatuh pertama kali dalam sejarah kedua kelompok ini. Peristiwa tersebut terjadi saat Buondelmonte de Buondelmonti anak dari keluarga terpandang dari partai Guelf menggagalkan pernikahannya bersama putri dari keluarga ternama dari keluarga Donati Ghibelline. Dia memilih untuk menikah dengan perempuan lain. Keluarga Donati tidak menerima keputusan Buondelmonte. Mosca memimpin pasukan Donati yang dibantu keluarga Limberti membunuh Buondelmonte bersama kekasihnya. Dari peristiwa itu, terjadilah pertumpahan darah dari dua keluarga di jembatan Ponte Vecchio Florance. Kejadian ini disesalkan oleh kedua kubu pada generasi-generasi Florance 
setelahnya. Dante mengutuk Mosca atas kejadian ini dengan menyebutnya lebih dari sekali di kidung-kidung nerakanya, yang digambarkan dengan seorang dengan tubuh yang buntung di neraka lapis ke delapan, tempat para pendosa yang memecah belah golongan.

\section{... Then one,}

Maim'd of each hand, uplifted in the gloom

The bleeding stump, that they with gory spots

Sullied his face and cried: "remember thee

Of Mosca too.." (Inferno 28. 117)

[Lalu seseorang dengan kedua lengannya yang buntung, muncul di tengah kegelapan. Si buntung yang bercucuran darah, sehingga mereka dengan bercak darah kering di wajahnya berteriak: "Ingatlah engkau tentang kisah Mosca juga..."

Sejak saat itu, pertumpahan darah antara dua kelompok itu tidak pernah habis lebih dari dua abad lamanya. Dante menyalahkan Mosca sebagai pemicu konflik berkepanjangan tersebut.

Belum berakhir sampai di situ. Pada tahun 1294, Bonedetto Caetani resmi menjadi pemimpin katolik Roma dengan gelar Paus Boniface VIII. Dia menerbitkan satu fatwa yang kontroversial mengenai indulgensi. Indulgensi merupakan surat pengampunan dosa yang terdapat dalam doktrin katolik. Surat pengampunan dosa yang diterbitkan oleh gereja ini, menurut Boniface VIII, adalah suatu bentuk metafora moneter yang bersumber dari Matius: 25-26. Dari sumber tersebut ditafsirkan bahwa dosa seseorang dapat diukur seperti halnya cara kerja neraca akuntansi. Nominalnya dapat diganti dengan uang. Paus Boniface VIII mempermudah proses pengampunan dosa seorang Katolik dengan menjual Indulgensi. Inilah cikal bakal munculnya praktek jual-beli surat pengampunan 
dosa yang beberapa abad kemudian memunculkan gerakan keras kaum Protestan. (Durling 2003: 5).

The Divine Comedy mengabadikan Paus Boniface VIII ke dalam salah satu lapis nerakanya tempat para penerima sogokan.

..."tell me now

What treasure from Saint Peter at the first

Our lord demanded, when he put the keys

Into his charge? Surely he asked no more

But 'Follow me!' Nor Peter, nor the rest,

Or gold or silver of Matthias took,

When lots were cast upon the forfeit place

Of the condemned soul (Judas)..." (inferno 19: 80)

[katakan padaku sekarang apa kekayaan yang diperoleh sang junjungan kita Santa Petrus, saat dia diberi tanggung jawab atas kuncikunci (istana) itu? Ia tak meminta apa-apa kecuali 'ikuti aku' tidak hanya Petrus atau yang lainnya, ataukah emas, atau perak yang Matius dapatkan ketika dia disiksa di tempat si jiwa terkutuk itu (Judas)]

Boniface VIII dijebloskan ke neraka penerima sogok bahkan sebelum ia meninggal. Gambaran tubuhnya yang terbalik, tertancap di tanah hingga yang tampak hanya perut dan kaki yang tegak berdiri itu berdampingan dengan Paus Nicholas III yang juga melakukan kejahatan yang sama. Dante mengkritik sang Paus atas Indulgensi yang diperjual-belikannya itu. Dia memberikan pelajaran pada Bonface VIII, dengan membandingkannya dengan tokoh-tokoh terdahulu, seperti Santa Petrus dan Matius, yang menjalani siksaan hidup dalam membela agama tanpa meminta balas jasa.

Fatwa jual-beli mendapat kritikan keras separuh internal kelompok Guelf. Tak ayal penghujung abad ke-13, perpecahan di kalangan Guelf pun meletus. Guelf terpecah menjadi dua kubu yaitu Guelf Putih dan Guelf Hitam. Guelf Putih menolak kepausan Boniface VIII berikut dengan fatwa-fatwanya dan Guelf Hitam 
berada di belakang Boniface VIII. Kedua faksi memperkuat masing-masing basis militernya selama beberapa tahun berselisih. Pada tahun 1300, Paus Boniface VIII mengundang kaveleri Guelf Putih ke Roma untuk mendiskusikan penolakan mereka terkait penjual-belian Indulgensinya. Rombongan yang terdiri atas enam ksatria Guelf Putih tersebut di antaranya adalah Guido Cavalcanti, dan Dante Alighieri.

Pada saat yang sama, kubu Guelf Hitam menyerang Guelf Putih yang tersisa di Florance dan menduduki kota kelahiran Dante itu. Para Kaveleri yang pulang dari Roma itu akhirnya, oleh penguasa baru, tidak diperkenankan memasuki kota mereka termasuk salah satu di antaranya adalah Dante. kehilangan pilihan, mereka menghabiskan separuh usia mereka yang terakhir sebagai orangorang yang kehilangan kota atau eksil. Dante menuduh Paus Boniface VIII adalah otak dari tragedi tersebut. Dalam Comedia, nama Boniface VIII disebut lebih dari sepuluh kali. Hingga Dante wafat, Florence masih dikuasai oleh Guelf hitam.

\subsubsection{Riwayat Hidup Dante Alighieri}

Dante Alighieri dilahirkan pada tahun 1265. Ini merujuk pada kalimat pembuka The Divine Comedy “In the midway of our mortal life. ”(Inferno 1: 5). Menurut catatan Henry (1980: 5), Dante mengisyaratkan awal penulisan The Divine Comedy adalah pada usianya yang ke tiga puluh lima di tahun 1300. Lalu merujuk pada catatannya Convito, dia menjelaskan bahwa hidup manusia itu seperti tali busur dan lengkungannya, dimana titik tertinggi/terjauh (setengah dari tujuh puluh, sebagaimana Mazmur 89:10 menyatakan, vulgata, usia rata-rata 
manusia adalah 70 tahun) mereka tengah dibina oleh alam pada usia tiga puluh lima tahun.

Ayahnya bernama Alighiero degli Alighieri dan ibunya bernama Bella. Ayahnya berasal dari keluarga terpandang yang secara turun-temurun memihak faksi Guelf. Tahun kelahiran Dante merupakan tahun-tahun kejayaan Guelf setelah berhasil menaklukkan Ghibelline di Florance pada tahun 1250. Ia mengaku moyangnya adalah tokoh penguasa yang bukan hanya menguasai Florance tetapi juga Tuscany. Ini direkam Dante ketika ia bertemu moyangnya Caccaguida degli Elisei di Surga (Paradiso canto 15-18).

Pertemuan dengan moyangnya ini pula yang menggambarkan masyarakat Florance yang tangguh, damai dan seimbang, dimana "setiap cinta menjadi hak semua orang" pada saat itu, atau House was none Void of its family (Paradiso 15: 350) [Rumah tak dibiarkan kosong oleh keluarganya] karena pada masa Dante rumah dibangun semewah-mewahnya untuk menunjukkan kebesaran satu klan meski itu sama sekali tidak difungsikan sebagai rumah, atau kosong dari penghuninya. Inilah kota Florance yang diidealkan Dante. Diketahui Cacciaguida hidup pada tahun 1050-an karena ditemukannya dinding Florance yang bernama dinding Cacciaguida yang dibangun pada tahun 1072. Ini berbeda dengan apa yang ia saksikan mengenai warga Florance yang pecundang dan tunduk pada tirani. Dante menggambarkan warga Florance hanya berani untuk berteriak “Behold I stoop!” (Purgatory 6: 169) [Lihatlah, aku sudah tunduk!].

Beranjak remaja, Dante sudah menggemari membaca soneta yang ditulis oleh ahli hukum, fisikawan dan aristokrat. Sejak itu, dia mulai belajar menulis. 
Dia menulis prosa-prosa cinta yang memuja keindahan sesosok perempuan yang sesekali ia menyebutnya dengan donna angelicata tapi di tempat lain ia menyebutnya dengan nama Beatrice, yang digambarkan dengan gadis yang begitu suci dengan keindahannya yang tidak dapat dibandingkan dengan metafora apapun (Durling, 1996: 11). Pertemuannya dengan Beatrice adalah pertemuan singkat pada saat dia berusia sembilan tahun. Sejak saat itu dia selalu mengagumi Beatrice sebagai sosok perempuan ideal.

Pada tahun 1277, Dante bertunangan dengan gadis dari keluarga Donati bernama Gemma Donati. Pertunangan politik ini diamini oleh Dante. Mereka menikah pada tahun 1280. Dari Gemma dia memiliki beberapa anak. Tidak ada catatan apapun tentang Gemma dan anak-anaknya itu. Sedangkan Beatrice Portinari adalah anak dari Folco Portinari. Beatrice menikah dengan seorang bankir yang kaya raya bernama Simone de’ Bardi. Dari pernikahannya itu, mereka juga memiliki beberapa anak. Sebagai catatan, Seperti pernikahan Dante dan Gemma, kehidupan domestik mereka tidak dituliskan sedikitpun di dalam puisipuisi Dante. Beatrice menjadi inspirasi dan protagonis di dalam puisi-puisi Dante. Ia semakin menginspirasi Dante setelah dia meninggal di usia yang sangat muda, 24 tahun. Kehilangan Beatrice membuat Dante menelurkan tulisan-tulisan dimana dia dan Beatrice sebagai tokohnya. Puisi-puisi Dante yang menghadirkan sosok Beatrice di antaranya La Vita Nouva, La Rime, Convivio, dan The Divine Comedy. Kematian kaisar Charles of Anjou (tertulis di Purgatory 7, terlambat menyadari bahwa pewaris tahtanya telah menghancurkan nama baiknya), pada tahun 1284, mengubah tatanan politik Romawi. Pada masa Charles I, Ghibellini 
tidak diizinkan untuk melakukan ekspansi di wilayah-wilayah Guelf. Namun, di bawah kekaisaran anaknya, Charles of Naple, Ghibellini menguasai banyak kota di Itali. Kekuatan Ghibelline semakin besar hingga menaklukkan Pisa dan Verona. Pada masa ini, Dante membuktikan bahwa pernikahan politik keluarganya itu tidak mengubah semangat juangnya untuk membela Guelf dan menantang keluarga mertuanya Donati Ghibellini. Akhirnya, tahun 1289 adalah tahun kejayaan bagi Dante. Dia dan kavaleri Guelf mampu memukul mundur pasukan Ghibelline Arezzo yang mengepung Florence. Dante menyaksikan sendiri pasukan Ghibellini mengepung kotanya dengan membawa Light-armed Squadron and fleet foragers (Inferno 22: 89).

Kejayaan Dante tidak berlangsung lama. Pada tahun kedua Benedetto Caetani terpilih sebagai Paus, Dante yang menentang fatwa Paus Boniface VIII mendapat perlawanan sengit dari klannya sendiri. Faksi Guelf terpecah menjadi dua kubu. Dante berpihak pada Guelf Putih yang menentang fatwa Boniface VIII terkait jual-beli Indulgensinya. Akibat perseteruan itu, Dante tidak diperkenankan masuk ke Florence, setelah memenuhi undangan sebagai delegasi menemui Paus Boniface VIII di kota Roma. Kepulangannya bersama delegasi Guelf Putih ditahan di depan gerbang kota Florence oleh pasukan kerajaan. Sejak itu, Ia menghabiskan waktunya berkelana mencari suaka. Sedangkan klan Guelf Putih yang tersisa di dalam kota Florance dibantai oleh Guelf Hitam yang bekerjasama dengan Ghibellini di bawah perintah Philip IV.

Dante bersama Guido Cavalcanti menyusuri wilayah dari satu kota ke kota yang lain. Tempat pertama yang ia singgahi adalah Verona dan menjadi tamu 
Bartolomeo I Della Scala. Setelah itu, dia berhijrah menuju Sarsana di Liguria. Dia pun bertemu dengan seorang wanita sederhana di Lucca yang diabadikan dalam purgatory 24: 243 , bernama Gentucca:

somewhat I heard him whisper of Gentucca....

$\cdots$

He, answering, straight began: "Woman is born,

Whose brow no wimple shades yet, that shall make

My city please thee, blame it as they may. (Purgatory 24: 243)

[Sepertinya aku mendengar nya bergumam menyebut nama Gentucca.... Ia memulai menjawab: "Wanita yang terlahir dengan alis yang belum sekalipun tergores oleh pensil rias. Dialah yang menjadikan kotaku mau menerima kehadiranmu, bukan yang lain.]

Namun, tidak kalah tinggi rasa hormatnya adalah kepada Kaisar Henry VII yang memberinya perlindungan dan rasa aman selama hidup sebagai seorang eksil. Ia juga merasa sangat berterima kasih pada sang kaisar karena berhasil menaklukkan Guelf Hitam di Florance, meskipun pada akhirnya pasukan Henry VII dipukul mundur dari kota kelahiran banyak seniman-seniman Renaissance itu. Hal ini disebabkan persoalan kompleks antar wilayah yang dijalin oleh benang kusut kepentingan politik. Henry VII pun menarik mundur pasukannya setelah menduduki Florance dalam waktu yang tidak begitu lama. Pada tahun 1313, Kaisar Henry VII meninggal dunia. Dante menuliskan sebuah prosa berjudul De Monarchia untuk mengenang sang raja. Di tempat yang lain, dia pun menyisipkan nama Henry VII dalam puisi The Divine Comedy. Tidak ragu-ragu Dante memasukkan kaisar asal Jerman itu di Empyren, puncak tertinggi surga Dante.

...Shall rest the soul

Of the great Harry, he who, by the world 
Augustus hail'd, to Italy must come

Before her day be ripe (Paradiso 30: 415)

[...akan beristirahat dengan tenang jiwa yang mulia Harry, dialah yang membuat seluruh dunia membanggakan Augustus, untuk Itali ia yang datang sebelum negeri ini benar-benar mapan.]

\subsubsection{Commedia; Perkawinan Mitologi, Ilmu, dan Iman}

Selain mendokumentasikan kisah hidupnya yang tragis, dan romantika bersama Beatrice di alam kematian, Dante juga menyisipkan komentarnya terhadap perkembangan kontemporer filsafat, puitika, dan religiusitas pada masanya di dalam The Divine Comedy, terutama dalam seri Paradiso. Selain puisi, filsafat, dan penafsiran Al-kitab, hal yang tidak kalah pentingnya dari perkembangan kesusasteraan Itali dan Eropa secara keseluruhan pada saat itu adalah kisah-kisah Mitologi. Mitologi pagan merupakan spirit yang menjaga kebanggaan patriarch Romawi, terutama kisah kejayaan Troy yang tidak lain adalah nenek moyang bangsa Itali dan Romawi, juga perjalanan Aeneas yang heroik dalam menemukan tanah yang dijanjikan oleh dewa Zeus. Cerita legenda yang dibuat oleh Virgil tersebut masih beredar di kalangan bangsawan dan masyarakat umum di Itali.

Cerita-cerita mitologi yang diwariskan dari Yunani dan Romawi kuno ini dipandang tidak mengganggu keimanan masyarakat Kristen di Itali dan Eropa. Di masa tersebut, menurut Habib (2005: 177), Karya-karya kristen yang tersebar tidak menyingkirkan teks-teks klasik Pagan, tetapi menaklukkan karya-karya tersebut dengan menjadikannya bagian dari teks dalam interpretasi alegoris yang 
tentunya konsisten dengan doktrin gereja, seperti karakter Minos yang disisipkan ke dalam comedia Dante:

“... approachest!” when he saw me coming, cried minos, relinquishing his dread employ,

"look how thou enter here;.." (inferno 5: 21)

[“... mendekatlah kemari!” ketika ia melihatku mendatanginya, berteriaklah Minos, sambil menghentikan sejenak tugasnya yang mengerikan itu "hei, bagaimana engkau bisa masuk ke tempat (neraka) ini."]

Minos, anak dari dewa Zeus, di dalam mitologi Yunani adalah sosok jahat yang hidup di dalam gua. Namun, di neraka Dante, Minos adalah hakim adil yang dengan ekornya mampu membaca dosa terberat seseorang lalu dengan ekornya yang panjang itu jiwa yang malang dihempaskan ke neraka yang paling tepat untuk dia.

Di abad ke-12 Ibnu Rushd menulis karya-karya mengenai komentarnya terhadap pemikiran Aristoteles. Sejak masa itu perkembangan teknologi pemikiran filsafat arab, meskipun diikat oleh paradigma Islam, tergolong maju dengan pesat. Pada masa yang sama, filsafat, sejak abad ke-4, di Eropa sama sekali dibungkam oleh gereja. Mereka yang mengkaji filsafat, oleh Paus, dianggap bid'ah. Pada masa Kaisar Frederick II, di abad ke-13 terjadi asimilasi pemikiran dari dunia arab (islam) dan Eropa. Walaupun mendapat kecaman dari pihak gereja, Sang Kaisar mengizinkan karya-karya Ibnu Rushd, ibnu Sina, dan beberapa tokoh islam lainnya diterjemahkan dan dikaji oleh ilmuwan Eropa. Dari proses asimilasi ini, muncullah dialektika pemikiran antara Arab dan Eropa. Salah 
satu nama yang muncul sebagai pioneer filsafat yang menghubungkan dengan konsep teologi Kristen adalah Thomas Aquinas.

Dante banyak mengadopsi pemikiran Thomas Aquinas. Salah satu pemikirannya yang kontroversial dan disenangi Dante adalah mengenai Kehendak Tuhan. menurut Aquinas (Habib, 2005: 204), seberat apapun pelanggaran dan kontrasnya tindakan seseorang dengan al-kitab, hanya dengan kehendak-Nya seorang manusia bisa terbebas dari dosa juga takdir buruk dan begitu pula dengan pemilihan orang-orang yang Dia selamatkan adalah misteri. Pandangan seperti ini, sampai pada abad ke-14 masih menjadi diskursus yang kontroversial, mengingat era tersebut adalah masa dimana Al-Kitab adalah janji Tuhan yang tidak akan Dia ingkari. Dante membenarkan itu di dalam Commedia. Cerita ini dimulai saat Dante terkejut mengapa seorang pagan, Ripheus of Trajan menghuni surga Jupiter.

Wherefore, of grace, God oped in him the eye

To the redemption of mankind to come;

Wherein believing, he endured no more

The filth of Paganism, and for their ways

Rebuked the stubborn nation. The three nymphs,

Whom at the right wheel thou beheld'st advancing,

Were sponsors for him, more than thousand years

before baptizing... (Paradiso 20: 373)

[oleh karena itu, atas kehendak-Nya, Tuhan menjadikan matanya peka untuk melihat masa depan manusia dan juga penyucian dosa mereka; setelah imannya tumbuh, ia merasa terhina terlahir sebagai seorang paganisme, dan dengan kelakuan-kelakuan mereka ia menegur bangsanya yang keras kepala. Tiga bidadari (iman, amal, dan harapan), berada di sebelah kanan roda yang engkau perhatikan bergerak maju itu, yang membaptisnya, lebih dari seribu tahun yang lalu sebelum adanya proses pembaptisan]. 
Terkait Kehendak (grace) juga, selain Ripheus dari Trojan, disebutkan ada tiga nama pagan dalam The Divine Comedy disebutkan selamat dari siksa neraka, yang disebabkan misteri Kehendak ala Aquinas, yaitu Virgil penulis kisah Aenead, Statius penulis Achilles, dan Trajan dari Roma. Selain dari itu, pemahaman Neoplatonik menjadi ruh yang memperkuat basis filsafat dan diskusi eskatologi masyarakat akhir medieval. Pemahaman bahwa tubuh memiliki jiwa lebih dari satu dalam filsafat Plato juga dicerca di masa ini.

Yang paling mengejutkan adalah pertemuan mesra antara peradaban kristen dan Islam. Ibnu Rushd dan Dante adalah titik perjumpaan yang misterius. menurut Asin (1927: 135) dalam teks Dante ditemukan kecocokan pemikiran dan gagasan filosofis serta gaya bahasa, dan tempramen religius Ibnu Rushd, terutama dalam karyanya yang berjudul Futuhat. Asin melanjutkan bahwa seharusnya Dante mempunyai akses yang kuat untuk memahami dan mengagumi Futuhat karya Ibnu Rushd. Namun menurut referensi yang lain, karya-karya Ibnu Rushd diperkenalkan ke dalam bahasa Itali oleh Siger de Brabant - yang diabadikan di Paradiso canto 10, termasuk menerjemahkan Al-Qur'an ke dalam bahasa Itali.

Dari penafsiran Al-Qur'an tersebut, Asin menemukan bahwa Dante mengkonstruksi eskatologinya tersebut terinspirasi dari pemahaman mengenai isi

Al-Qur'an terutama surah ke-17 Al Isra ayat pertama.

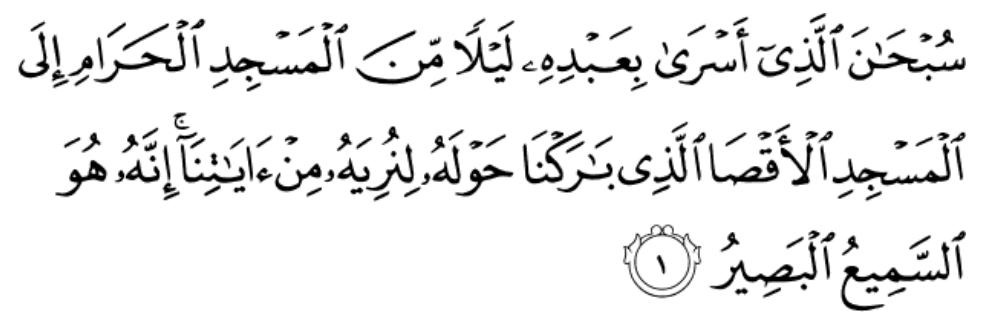


[Maha Suci Allah, yang telah memperjalankan hamba-Nya (Muhammad) pada suatu malam dari Al Masjidil haram ke Al Masjidil aksa yang telah Kami berkahi sekelilingnya agar Kami perlihatkan kepadanya sebagian dari tanda-tanda (kebesaran) Kami. Sesungguhnya Dia adalah Maha Mendengar lagi Maha Melihat. (Q.S; Al-Isra: 1)]

Kisah perjalanan Muhammad menuju surga dan berbagai kisah-kisah yang beredar mengenai perjalanan Sang Rasul tersebut menjadi perhatian menarik bagi Dante. Ia juga menambahkan konstruksi surganya dengan gambaran Tangga Jakob sebagaimana yang tertulis di Al-kitab (Genesis 28. 12) yang letaknya di surga Saturnus (Paradiso 21-22). Keakraban Dante dengan peradaban islam

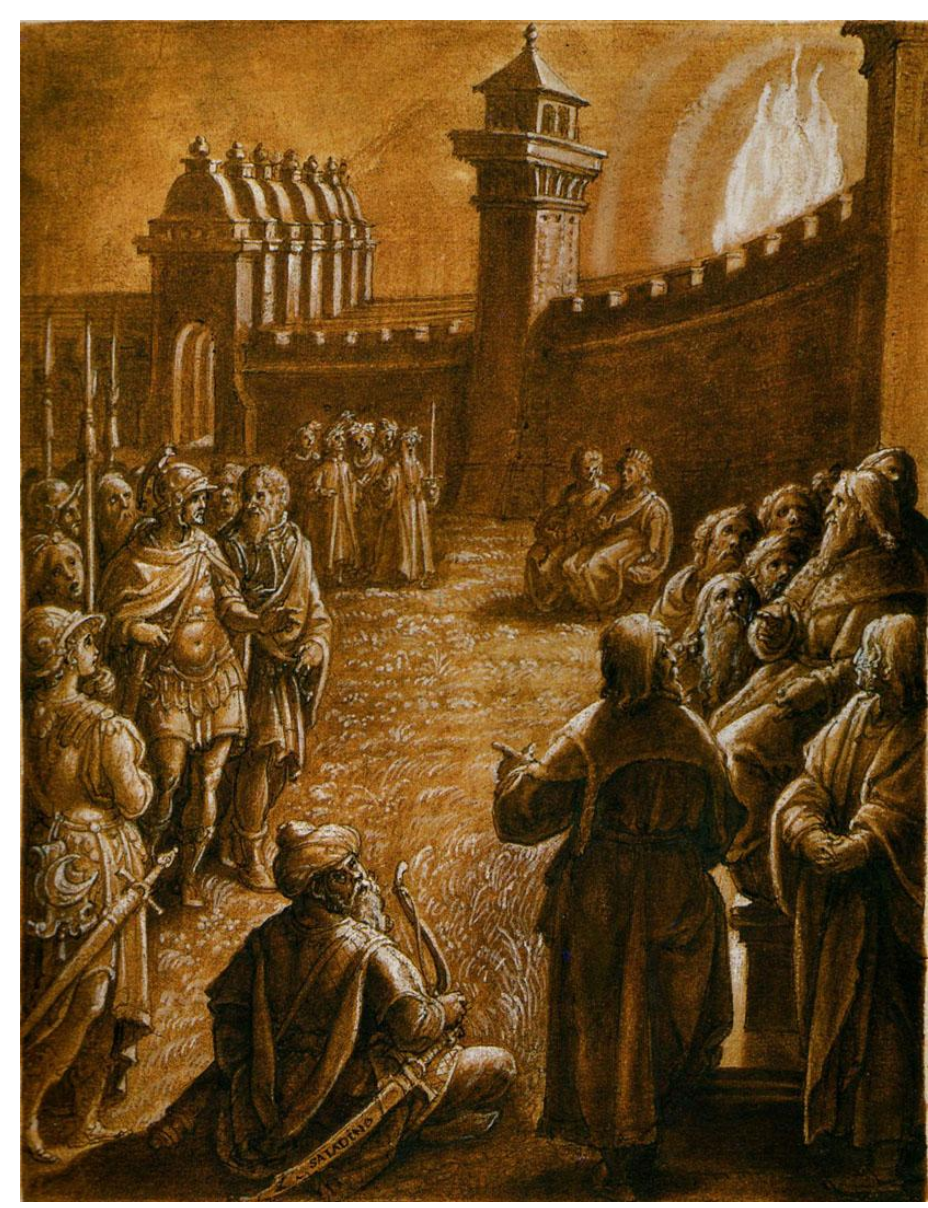

Gambar 2.1 Ilustrasi Stadanus mengenai visi dan penghuni neraka Limbo 
bukan hanya itu, Dante mengenal baik nama-nama tokoh berpengaruh di dunia Islam dan mengabadikannya di dalam magnum opus-nya. Mereka ditempatkan di lokasi yang cukup indah untuk orang-orang yang belum terbaptis, neraka Limbo

And sole apart retired, the Soldan fierce

Euclid and Ptolemy, Hippocrates, Galenus, Avicen, and him who made that commentary vast, Averroes (Inferno 4: 20)

[dan satu-satunya yang terpisah adalah Salahuddin yang garang, .... Euclid dan Ptolemy, Hyppocrates Gelenus, Ibnu Sina, dan dia yang memiliki pandangan yang luas, Ibnu Rushd]

\subsection{Ringkasan Perjalanan Sang Peziarah}

The Divine Comedy merupakan puisi panjang yang berisi kisah perjalanan sang protagonis - tidak lain adalah Dante Alighieri - menemui kekasihnya, Beatrice di alam setelah kematian. Perjalanan Dante ini dibagi ke dalam tiga babak yang masing-masing dibagi lagi ke dalam banyak canto (red. kidung). Setiap canto terdiri dari 115 sampai 150 baris yang mengisahkan visi atau masalah tertentu yang mesti dilaporkan oleh Dante. Sebagai contoh dalam Inferno canto 28, kidung tersebut menceritakan Perjalanan Dante memasuki lapis neraka ke delapan di kantung ke sembulan. Lapis neraka tersebut berisi orang-orang (pemimpin) yang senang menabur benih-benih perpecahan yang menyisakan pertikaian hingga ke generasi-generasi selanjutnya. Konsekuensinya, Dante melihat tokoh-tokoh dunia itu disabet dengan pedang oleh malaikat. Ada Ali yang wajahnya hampir terpisah antara sisi kiri dan kanannya. Ada yang perutnya robek, Ada yang tangannya buntung. Ada pula yang kepalanya terpisah dari badannya. 
Setiap visi yang muncul diceritakan pula alasan mereka dibuang ke kantung neraka tersebut.

Perjalanan pertama berjudul Inferno, merupakan perjalanan menelusuri neraka yang terletak di pusat bumi. Inferno terdiri 34 canto. Perjalanan kedua berjudul Purgatory, berisi kisah perjalanan Dante mendaki gunung penyucian dosa menuju taman Eden, yang terletak di puncak gunung tersebut. Purgatory terdiri 33 canto. Perjalanan yang terakhir berjudul Paradiso. Paradiso menceritakan perjalanan sang peziarah terbang ke angkasa menyusuri tingkatan demi tingkatan surga, demi menemui sang Kristus. Perjalanan Paradiso ini dibagi menjadi 33 canto.

\subsubsection{Inferno}

Kisah ini diawali dengan tersesatnya protagonis di tengah hutan rimba di sebuah malam. Ia terus berjalan pelan mendaki puncak sebuah bukit. Karena ketakutan, ia mengabaikan keindahan cahaya gemerlap bintang-bintang di atas langit, lalu melanjutkan perjalanan yang ia tidak tahu ujung pangkalnya. Di tengah perjalanan ia dihadang harimau ganas dan srigala betina yang kelaparan. Namun, sesosok hantu tiba-tiba muncul dan berhasil mengusir binatang-binatang jahat tersebut. Hantu itu selanjutnya dikenal bernama Virgil. Virgil pun mengajak Dante berjalan-jalan ke neraka dan gunung Purgatori.

Sebelum memasuki neraka, Virgil mengajak Dante untuk menemui seorang arwah perempuan. Perempuan itu digambarkan dengan berbagai keelokan sebagaimana keahlian Dante memuji seorang gadis. Perempuan itu adalah Beatrice, perempuan idamannya yang telah lebih dahulu meninggal. Beatrice 
memerintahkan Virgil untuk mendampingi Dante menuju taman Eden agar bisa bertemu secara langsung dengan Beatrice. Beatrice pun menghilang pergi.

Dante memasuki gerbang neraka. Dia terkejut melihat tampilan neraka yang dihuni jutaan manusia. Dante mengenali salah satu penghuni neraka, Paus Celestine V. Arwah-arwah itu berbaris menunggu di tepian sungai Acheron, untuk diseberangkan oleh Charon. Virgil meminta Charon untuk menyeberangkan mereka. Di perjalanan tiba-tiba terjadi gempa. Dante pingsan. Pada saat terbangun, Dante merasa sudah sampai di tujuannya. Ia terkejut melihat neraka seindah itu, disebut limbo. Limbo merupakan neraka bagi mereka yang selama hidupnya melakukan kemuliaan tetapi kristus tidak menjamin keselamatannya atau tidak dibaptis, atau hidup sebelum kelahiran kristus. Disana ia menikmati Homer membaca puisi dan mendengar retorika Plato.

Virgil mengajak Dante segera memasuki kegelapan yang lebih dalam. Di neraka selanjutnya dia bertemu dengan penjaga neraka bernama Minos. Monster ini bertubuh besar dan mempunyai ekor yang sangat panjang. Ekor ini berguna untuk mengidentifikasi dosa arwah yang diadilinya. Setelah arwah itu tercium dosa terbesarnya, ekor Minos melilit di tubuh arwah lalu melemparnya jauh ke neraka yang pantas untuk dia. Neraka tempat Minos bertugas adalah neraka berahi untuk mereka yang diperbudak nafsu. Di tempat itu, para budak nafsu dihempas angin kencang yang abadi.

Neraka berikutnya adalah neraka rakus. Neraka ini selalu dituruni hujan es yang mencair dan lumpur yang berbau busuk. Neraka ini dijaga Carberus, seekor monster besar berkepala tiga. Masing-masing kepalanya berwujud seperti kepala 
anjing. Dia menjaga kubangan lumpur yang dihuni para arwah yang rakus. Karena lapar dan rasa haus, arwah-arwah itu memakan lumpur yang bau itu. Neraka ke empat adalah neraka serakah dan malas. Setiap orang mendorong batu besar yang dikiranya emas. kelompok pemalas dan kelompok serakah mendorong batu dari sisi yang berlawanan. Mereka saling berteriak satu sama lain. "untuk apa kau menimbunnya?" "untuk apa kau menyia-nyiakannya"

Tidak jauh dari itu, ia menemukan sungai Styx yang hitam dan bau. Di sanalah penghuni neraka selnjutnya disiksa, neraka marah dan iri. Mereka semua direndam ke dalam sungai itu. Setiap gerak memunculkan gerakan yang lain, lalu memancing emosi yang lain, sehingga mereka di dalam sungai saling pukul satu sama lain. Para tukang iri diminta menyanyikan hymne di dalam air sehingga ia menelan lumpur dan terdengar seperti orang yang berceracau. Dengan menggunakan jasa Phlegyas, duo peziarah ini menyusuri sungai Styx untuk memasuki gerbang kota Diz. Setelah memasuki kota hantu tersebut, Dante terkejut melihat seseorang yang terbakar muncul dari bawah tanah, lalu diikuti orang-orang berikutnya yang juga mendapatkan penderitaan yang sama.

Dante sadar bahwa dia sedang berada di Neraka lapis ke enam, neraka bid'ah. Mereka terbakar karena mereka dibaringkan ke dalam kubur yang sangat panas sehingga mereka tidak tenang di dalam pembaringannya. Mereka sengaja dikeluarkan dari dalam kubur agar Dante melihatnya mereka akan selamanya di dalam makam yang panas itu sampai hari kiamat tiba. Setelah Dante berbicara dengan beberapa penghuninya, salah satunya Kaisar Frederick II, kuburan itu 
tertutup kembali. Virgil menjelaskan neraka-neraka apa saja yang akan dilaluinya selanjutnya.

Neraka selanjutnya adalah neraka kekerasan. Neraka ini dibagi ke dalam tiga lingkaran yang lebih kecil. Dante memasuki ring pertama yang dijaga oleh Centaur. Ring ini dihuni oleh pelaku kekerasan pada tetangga, yaitu pembunuh, penjambret, dan perampok. Mereka direndam di dalam kubangan darah yang panas. Nessus mengajak duet peziarah tersebut berjalan-jalan menemui Alexander agung, Sextus, Xerxes, dan tokoh-tokoh melagenda besar lainnya. Mereka melanjutkan perjalanan ke ring berikutnya yang berisi pepohonan yang aneh. Pohon tersebut ternyata manusia yang tubuhnya bercabang-cabang. Mereka adalah para pelaku bunuh diri. Di ring terakhir dalam neraka ketujuh, Dante menemukan padang kering yang sangat luas, di sana orang-orang yang menyekutukan Tuhan dihukum. Mereka berkumpul di padang itu, sementara gunung api meletuskan laharnya. Mereka merasa kepanasan di kaki dan kepalanya, sehingga tampak seperti menari-nari.

Virgil dan Dante menaiki perahu untuk menyusuri sungai Phlegeton. Di tengah perjalanan, mereka menemukan tiga orang pelaku seks menyimpang (sodomi) yang bersembunyi dari hukuman neraka. Neraka selanjutnya adalah neraka para penipu ringan, bernama Malebogne. Mereka diantar oleh makhluk aneh bernama Geryon. Malebogne terdiri atas sepuluh kantung neraka. Kantung pertama yang mereka datangi adalah para penjual manusia, germo, dan pelaku gratifikasi. Mereka dikumpulkan dan satu persatu kepala mereka dihantam dengan gada. Seiring dengan itu, malaikat yang memukulnya berkata "Away, corupter! 
Here women are none for sale." Di kantung kedua, Dante menemukan para penjilat. Kuku mereka sangat tajam dan kepala mereka ditumbuhi jamur, sehingga mereka menggaruk dengan keras kepala mereka.

Di kantong selanjutnya Virgil dan Dante mendapati arwah-arwah tertancap dengan kepala di bawah. Ini kantong neraka untuk mereka yang menjual agama, tukang sogok, atau penerima sogok. Kantong keempat tempat para peramal, dan tukang sihir dihukum. Kepala mereka dipelintir ke belakang sehingga saat berjalan merasa sedang berjalan mundur. Di kantong berikutnya, mereka beremu makhluk jahat bernama Malacoda bersama sepuluh pasukannya. Malacoda dan pasukannya memiliki karakter kasar, namun, mudah dihasut. Pendosa yang ditempatkan di ring ini harus bertahan hidup dengan mengadu domba Malacoda dan pasukannya. Jika tidak, mereka akan tetap berada di kubangan nanah yang panas. Namun, apabila Malacoda dan kawan-kawannya sadar mereka sedang diadu domba, maka nasib buruk akan menimpa arwah penghasut tersebut. Tidak ada tempat yang nyaman di neraka. Ini adalah kantong untuk tukang Fitnah.

Ketakutan dengan perilaku pasukan Malacoda, Virgil dan Dante berlari menuruni lembah yang curam. Makhluk-makhluk aneh itu sepertinya mempunyai batas wilayah, sehingga mereka tidak lagi mengejar Dante ketika mereka berdua berhasil keluar dari batas wilayahnya. Kantong selanjutnya adalah neraka munafik. Kantong ke delapan adalah neraka para pemimpin yang menipu rakyat. Memasuki kantong ke sembilan, Dante merasa tidak sanggup melihat hukuman yang ada. Mereka adalah para pemicu perpecahan yang tubuhnya disabet dengan pedang oleh malaikat. Yang terakhir adalah kantong para penipu dan 
penyalahguna kepercayaan. Mereka mengidap penyakit yang parah sehingga nafasnya sesak dan tubuhnya lemas.

Untuk tiba ke lapis neraka selanjutnya, Dante harus melintasi kota raksasa, kota tempat para arwah yang dibeleggu dan berukuran sangat besar. Ini disesuaikan dengan keinginan mereka sewaktu masih hidup, menginginkan disembah sebagai Tuhan. Di neraka kesembilan. Kedua peziarah mendapati diri mereka berada di neraka beku. Yang terdiri atas empat sub-lingkaran. Yang pertama disebut Caina, yang kedua Antenora, sub-neraka ketiga disebut Ptolomea dan yang terakhir Judecca. Di sub-lingkaran terakhir tersebut, Dante dan Virgil bertemu dengan Lucifer yang menakutkan. Virgil mengajak Dante menyusuri gua yang terbentuk akibat jatuhnya Lucifer dari surga hingga menembus ke pusat bumi. Dante terus berlari hingga akhirnya mereka kembali bisa melihat langit dan menghirup udara segar. Berikut ini adalah ilustrasi neraka Dante oleh Durling. 


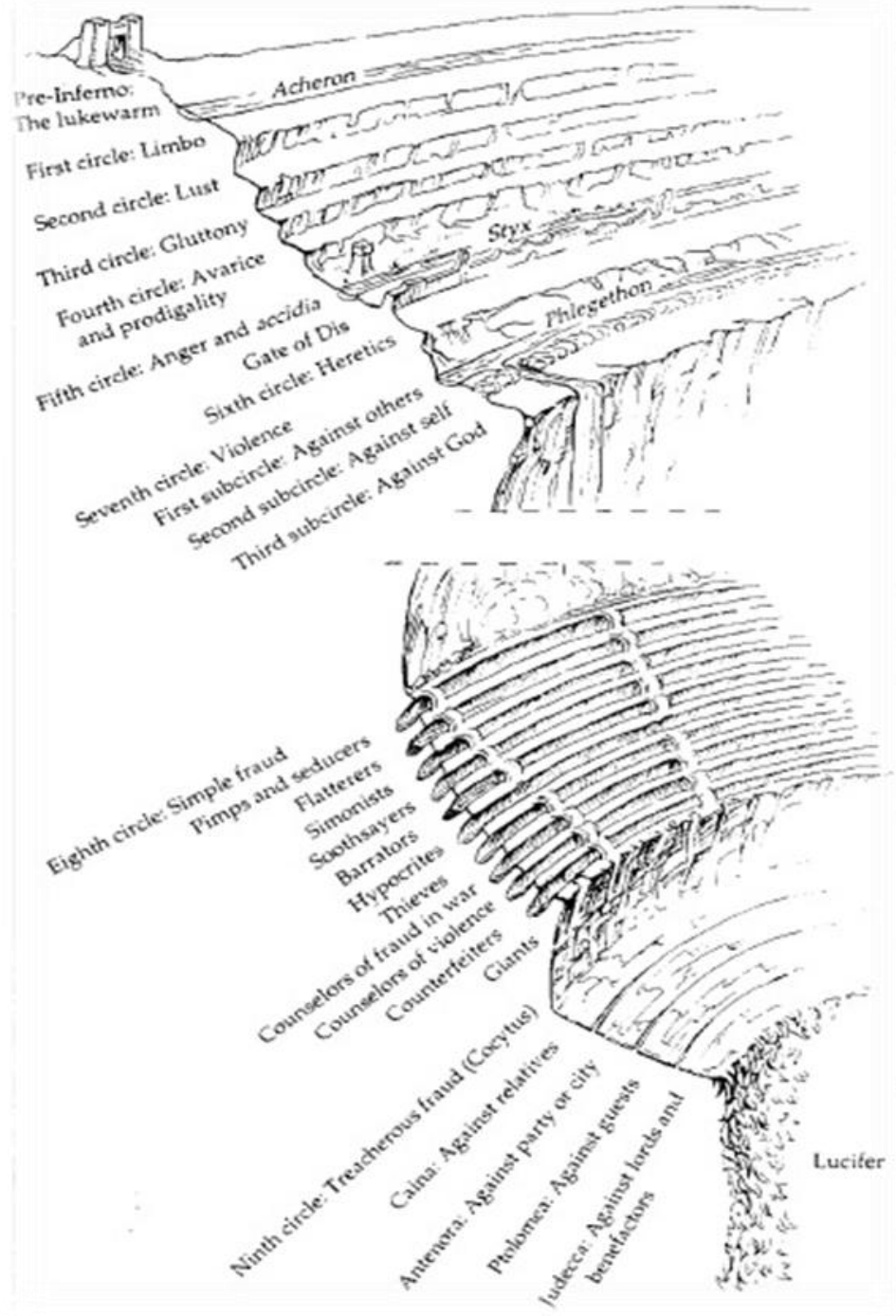

Gambar 2.2. Struktur neraka Dante yang diilustrasikan oleh Durling

\subsubsection{Purgatory}

Dante dan Virgil tiba di selatan. Meraka berada di bibir pantai dengan pemandangan yang sangat elok. Seorang tua bernama Cato menemui mereka dan meminta mereka mencuci wajahnya dengan embun dan mengikat kepala serta membuat ikat pinggang dari rumput yang tumbuh di pulau itu. Sesosok malaikat dari kejauhan mendatangi mereka dengan perahu yang berisi ratusan arwah. 
Malaikat itu menjalankan perahunya dengan mengepak sayap besarnya yang berbahan dasar bulu. Dante dan Virgil dipersilakan naik ke dalam perahu. Salah satu arwah mengenalinya. Sebelum mati namanya adalah Casella. Dante mengajaknya bernyanyi, menghibur para arwah menuju gunung purgatory.

Setiba di kaki gunung purgatory, Dante bertemu dengan arwah seorang bangsawan di Italia. Dia meminta agar keluarga arwah tersebut mendoakannya. Kata si arwah Gunung Purgatory menyimpan mistik. Setiap arwah memperoleh jarak yang berbeda-beda menuju puncak gunung tersebut, tergantung seberapa besar dosa yang dimilikinya. Setiap dosa akan menambah tiga puluh kali lipat jarak tempuhnya, kecuali mereka mendapatkan do'a dari orang-orang (keluarganya) yang masih hidup. Dante dan Virgil mencari-cari jalan untuk mendaki batu. Virgil menunjukkan sebuah jalan bebatuan. Merekapun memulai petualangan di Gunung Pugatory.

Duet peziarah menaiki batu-batu yang curam. Dante merasa kelelahan dan memilih beristirahat, namun Virgil memintanya untuk menaiki satu batu lagi untuk beristirahat. Di tempat istirahat, Dante terkejut melihat sekumpulan arwaharwah yang malas. Mereka menggoda Dante untuk ikut istirahat bersama mereka. Alih-alih mengiyakan, Virgil memaksa Dante untuk terus berjalan dan tidak tergoda oleh bujuk rayu arwah malas. Di kaki bukit selanjutnya, Dante bertemu dengan sekelompok arwah-arwah yang menjadi korban kekerasan dan terbunuh tanpa diupacarakan sebelum dimakamkan. Mereka menarik-narik Dante agar memberikan pesan kepada keluarga mereka untuk didoakan. Virgil menariknya keluar dan melanjutkan perjalanan karena malam hampir tiba. 
Di bukit selanjutnya, mereka bertemu dengan Sordello. Sama-sama berasal dari Mantua, Virgil dan Sordello begitu akrab. Ia menyuruh peziarah ini untuk nginap semalam di lembah pembuat kebijakan. Keesokan harinya, Sordello berjanji akan menemaninya menuju gerbang purgatory. Dalam tidur, Dante bermimpi diangkat oleh elang ke atas lagit. Saat terbangun ternyata mimpi itu isyarat nyata. Dia sudah berada di gerbang Purgatory bersama Virgil. Menurut Virgil, Dante diangkat oleh Lucia menuju gerbang, demi mempersingkat masa perjalanan mereka.

Di hadapan gerbang sesosok malaikat dengan pedang di tangannya menunggu. Semua yang masuk ke gunung purgatory harus mendapat izin dari malaikat tersebut. Dimulai dari Virgil, ia berlutut di hadapan malaikat itu. Sang malaikat menghunuskan pedang ke Virgil dan mengukir huruf $P P P P P P P(P$ sebanyak tujuh kali) di keningnya. $P$ berarti Peccatta atau dosa. Gerbang terbuka. Ruang taubat yang pertama adalah ruang kesombongan. Dante terkejut setelah memasuki ruang penyucian ini. Ia melihat begitu banyak patung dan ukiran yang menceritakan tentang penciptaan alam, dan rahasia-rahasia alam lainnya. Tibatiba muncul sosok yang aneh mendekati mereka. Dia memiliki kaki dengan bagian badan yang lainnya seperti batu. Ternyata semakin dekat Danta menyadari bahwa itu adalah sosok manusia yang sedang memikul batu besar di punggungnya.

Bentuk penyucian jiwa yang sombong adalah memikul batu besar di punggungnya. Semakin besar sifat sombong itu, semakin berat batu itu menekan punggung mereka, semakin membungkuklah dia. Dante bertemu dengan sahabat sesama penyair yang semasa hidup sangat sombong. Ia juga bertemu dengan 
sorang konselor yang tengah memikul batu. Ia terkejut mengapa konselor itu secepat ini tiba di di ruang kesombongan. Jawabannya, dengan berbuat baik terhadap sesama mempermudah untuk lebih cepat sampai ke tempat ini. Arwaharwah ini tidak mengenakan sehelai pakaian sedikitpun. Sepanjang jalan ia melihat ukiran demi ukiran seperti iblis yang dibuang dari surga, Nimrod yang mati di bawah menara Babel, dan lain-lain. Gambaran-gambaran tersebut adalah visualisasi kesombongan yang berakhir menyesatkan pelakunya. Tanpa sadar Dante dan Virgil kehilangan satu huruf $P$ di keningnya.

Ruang tobat selanjutnya adalah ruang pencucian perasaan iri. Tidak seperti ruang sebelumnya yang penuh dengan ukiran yang indah, tempat ini sedikit lebih sempit dan hampa. Arwah-arwah yang dicuci dosanya mengenakan pakaian kain yang usang. Mata mereka dijahit dengan kawat sehingga mereka tidak bisa melihat sekelilingnya. Setiap arwah berbaris memegang bahu teman yang ada di depannya. Digambarkan dengan orang buta yang dituntun oleh sesamanya buta. Dante bergegas cepat sehingga mereka sampai ke gerbang ruang ketiga. Dan $P$ di keningnya pun berkurang satu.

Memasuki ruang ketiga, Dante melihat tampilan kisah Joseph dan anaknya, juga tentang kisah Jesus yang meminta pada Tuhan mengampuni dosa para penganiayanya. Tiba-tiba Dante tersadar, lalu Virgil memberitahu Dante bahwa ia dari tadi tidur sambil berjalan sejauh tiga tikungan. Virgil menjelaskan bahwa mimpi Dante barusan adalah teladan mengenai sifat mengampuni yang merupakan lawan dari kemarahan atau murka. Dante menyadari bahwa saat ini mereka memasuki neraka rasa marah. Di neraka ini, para arwah terjebak di 
tengah kabut yang aromanya menyengat dan jarak pandang yang sangat pendek, sehingga satu sama lain saling menyahut untuk mengenal posisi temannya. Walaupun teriakan itu mengganggu satu dengan yang lain namun mereka berusaha saling memaafkan.

Virgil banyak memberikan contoh-contoh mitologi yang membuat Dante menyadari buruknya kemarahan dipelihara. Tiba-tiba malaikat datang untuk membantu duet peziarah untuk mempercepat tiba di ruang selanjutnya. Ruang selanjutnya adalah ruang tobat untuk rasa malas. Malas, yang menurut Dante disebabkan karena kurangnya atau bergesernya pengertian cinta oleh manusia, merupakan satu dari dosa yang perlu dicuci. Mereka yang berada di ruang ini akan menghabiskan waktu-waktu mereka melantunkan hymne yang berisi pujian-pujian kepada Tuhan. Dante bertemu dengan Santa Zeno asal Verona. Dia menceramahi Dante mengenai seperti apa cinta yang sesungguhnya yang diinginkan Tuhan.

Ruang selanjutnya adalah ruang pertaubatan serakah dan boros. Di ruang ini, mereka yang bertaubat mengenakan pakaian usang, dengan rantai di kaki dan lengannya. Rantai-rantai itu mengekang sehingga yang tampak mereka sedang berlutut. Di selasar ini Dante merasakan terjadi sebuah gempa. Dia dan Virgil mulai panik. Berbeda dengan jiwa-jiwa yang bertaubat yang berada di sana malah mendendangkan lagu-lagu sukacita. Dante terkejut. Diam-diam ternyata ada arwah yang memata-matai mereka sejak datang ke tempat itu. Ia bernama Statius. Statius memperkenalkan dirinya di hadapan kedua peziarah ini. Statius juga menjelaskan tentang gempa barusan yang merupakan penanda ada arwah yang berhasil naik ke surga. Statius sangat menghormati Virgil disebabkan profesi 
mereka sama, yaitu penyair. Ia menceritakan bahwa kuasa Tuhan yang mengangkat dia dari neraka, padahal dia orang yang mati tanpa baptis (bukan seorang kristen).

Ruang pencucian ke enam adalah ruang rakus. Statius menambah jumlah petualang Purgatory. Jiwa-jiwa rakus berada di sebuah taman dengan sungai yang airnya sejuk mengalir melewati sebuah pohon yang sangat besar. Pohon itu memiliki buah yang banyak. Anehnya, tidak satu arwah pun yang memakannya. Menurut penjelasan Statius, pohon ini adalah pohon yang sama yang buahnya dimakan Adam yang membuat dia turun bersama Hawa ke dunia. Arwah-arwah yang berada di ruang itu tampak sangat kurus, namun sangat lincah.

Ruang yang terakhir adalah teras pencucian birahi. Setiap ruh yang ada di tempat ini dibakar dalam waktu yang sangat lama sehingga api nafsu mereka habis. Dante dan kedua guide-nya, seperti biasanya, tidak ikut serta mengikuti pencucian dosa sebagaimana yang terjadi di ruang-ruang sebelumnya. Mereka melewatinya begitu saja setelah melihat visi yang terjadi di tempat penyucian tersebut. Malaikat penjaga taman Eden menolak mereka. Huruf $P$ di kening mereka masih tersisa satu. Mereka diminta untuk turun ke tungku pembakaran. Dante merasa ketakutan. Dia merasa berbeda dari yang lain. Dia merasa riwayatnya sudah habis di tungku itu, karena tidak mungkin ia memilih kembali. Virgil dan Statius mencobanya lebih dulu. Mereka membujuk Dante untuk turun ke tungku tersebut. Saat turun ke tungku itu, Dia tidak merasakan tubuhnya terbakar. Setelah mendengar penjelasan dari Virgil, Dia baru sadar bahwa itu adalah api penyucian. 
Bersama kedua sahabatnya Dante berhasil tiba di taman Eden. Dante mengagumi taman itu. Hutan dengan sungai yang bening mengalir pelan. Di sana mereka bertemu dengan seorang gadis yang cantik jelita. Gadis itu mengajak mereka berjalan-jalan melihat Surga Duniawi. Namanya Matilda. Virgil, Statius, dan Matilda memecah kekaguman Dante dengan bergantian menceramahi Dante tentang rahasia alam semesta. Setelah menceramahi Dante, Matilda menghilang. Tidak lama kemudian terjadi guncangan hebat. Malaikat-malaikat cantik mengiring sebuah kencana yang membawa seorang gadis yang sangat ia kenali. Virgil dan Statius tiba-tiba menghilang. Setelah terjadi dialog - yang bahkan membuat Dante sempat pingsan - dengan Beatrice, mereka pun terbang menuju langit. 


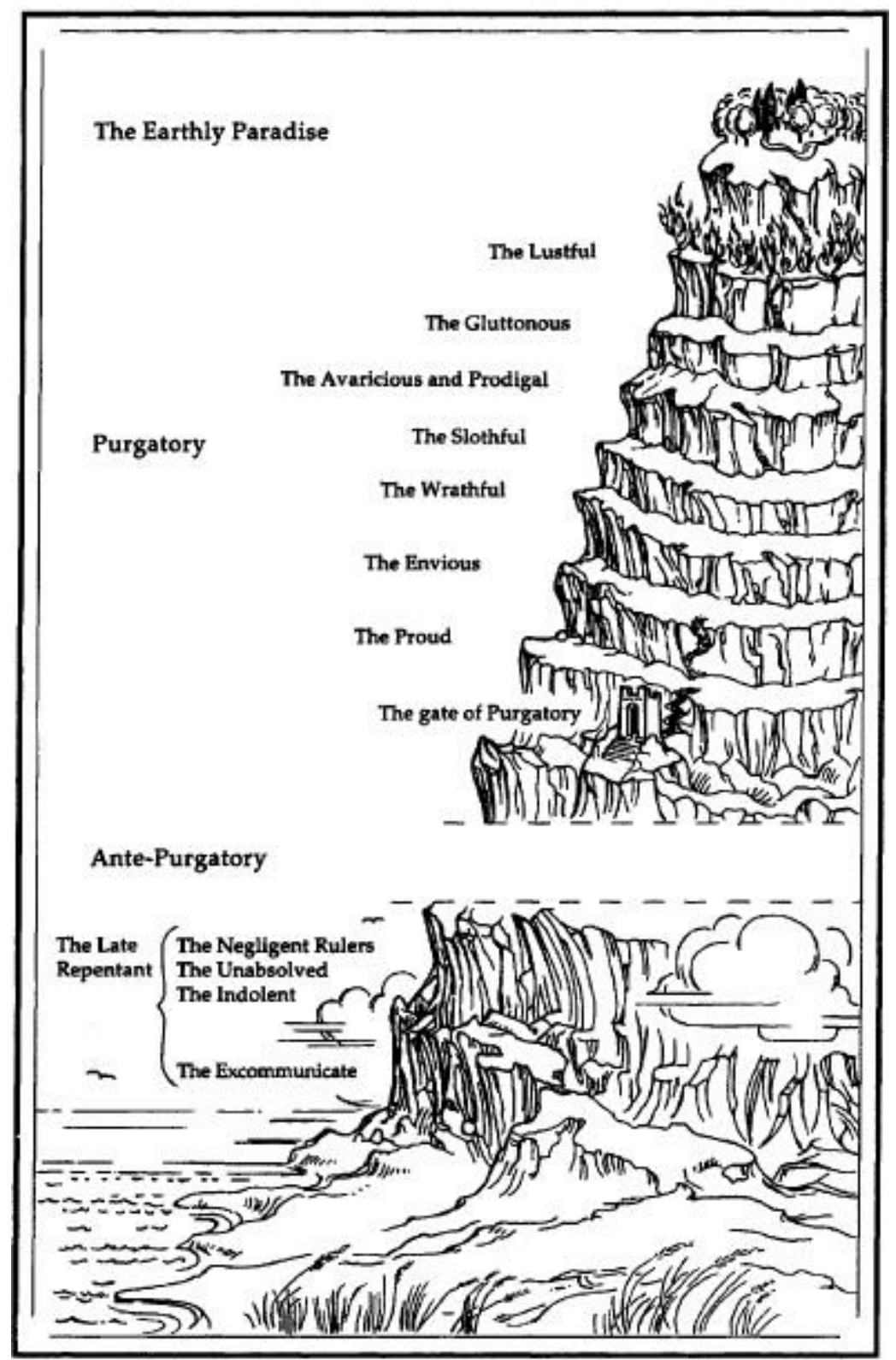

Gambar 2.3. Struktur Gunung Purgatory yang diilustrasikan oleh Durling

\subsubsection{Paradiso}

Dante akhirnya terbang bersama Beatrice. Beatrice yang dirindukannya selama bertahun-tahun itu kini berada dalam dekapannya menuju surga. Beatrice begitu cantik. Ia menceramahi Dante tentang lima elemen yang membentuk alam semesta. Sepanjang perjalanan ia melihat matahari semakin terang, lalu di titik- 
titik yang lain juga ada matahari yang lain. Tanpa membutuhkan waktu yang cukup lama, berkat kekuatan Apollo, Dante tiba di bulan, surga pertama.

Surga bulan adalah surga inkonsiten. Surga untuk orang-orang yang melanggar janji Tuhan. Ia bertemu dengan Piccarda. Ia seorang biarawati yang, oleh ayahnya, dipaksa menikah dengan seorang anak bangsawan. Ia pun menyerah dengan melepas janji sucinya kepada Kristus. Jika cahaya matahari adalah metafora surga, maka Piccarda menikmati indahnya surga hanya sekali waktu dan ia kembali dalam kegelapan lalu menunggu kembali datangnya terang. Ini adalah surga terhina, tetapi menurut pengakuan Piccarda, ia merasa begitu bahagia karena masih menemukan kasih Tuhan di tempat itu. Beatrice memberikan pesan kepada Dante bahwa seseorang ketika mengetahui jalannya adalah kebenaran, maka ia tidak boleh berpaling dari kebenaran yang ia yakini walaupun kematian adalah taruhannya. Ruh-ruh yang berada di surga ini adalah mereka yang sewaktu mempertaruhkan imannya melupakan adanya hope (baca: harapan) dari Tuhan.

Beatrice melesat ke atas meninggalkan bulan. Dante terkesima dengan kecantikan Beatrice yang makin bertambah. Tidak lama kemudian, mereka tiba di Merkurius, surga tingkat kedua. Ia bertemu dengan Justanian, kaisar Roma yang mereformasi aturan-aturan kekaisaran Romawi dengan menggabungkan kepentingan gereja dan tradisi pagan Romawi yang masih tumpang tindih. Ia adalah pemimpin Romawi yang mempersatukan kembali Bizantium dengan Romawi setelah kaisar Constantine memilih memindahkan ibukota Romawi dari Roma ke Konstantinopel, sehingga Romawi terpecah menjadi dua, Romawi barat 
dan Romawi timur selama berabad-abad. Surga Merkurius adalah surga bagi mereka yang semasa hidup hanya memfokuskan diri pada ketenaran, sehingga mereka lemah saat mereka jatuh.

Surga ketiga adalah adalah Venus. Menurut Beatrice, tiga bintang yang pertama adalah bintang-bintang yang memberikan pengaruh psikologis pada manusia di bumi. Jika bulan memendarkan ketidak-stabilan dalam mengambil keputusan, dan Merkurius memendarkan hasrat kekuasaan dan perang, maka Venus memancarkan cinta. Jiwa-jiwa bahagia yang berada di lingkup ini adalah jiwa-jiwa yang dipengaruhi baik sengaja maupun tidak disengaja oleh Venus. Kecintaan Charles of French, salah satu penghuni lingkup ini, pada anak-anaknya membuat ia lupa mengajarinya bertahan pada prinsip kebenaran, sehingga keturunannya hancur. Rahab adalah yang paling mulia di surga ini. Ia adalah seorang pelacur, dan tidak dibaptis, tapi dengan kasih sayangnya melindungi Yesus dari serangan kaum Yahudi, Yesus mengangkat dia dari neraka ke tempat tertinggi di surga kasih sayang ini.

Surga selanjutnya adalah matahari. Setiap jiwa yang ia temui di tempat ini memiliki halo di belakang kepala mereka. Mereka yang menghuni di lingkup surga ini adalah jiwa-jiwa yang semasa hidupnya memberikan kontribusi besar kepada manusia, terutama keilmuan. Dante melihat ada dua cincin raksasa yang berasal dari jiwa-jiwa yang melingkar. Dante disapa oleh St. Aquinas. Ia memperkenalkan nama-nama jiwa kekal di cincin pertama Matahari ini. Mereka yang diperkenalkan tersebut adalah para pengikut Santa Dominic dari ordo Dominican. Di cincin kedua adalah mereka yang menjadi pengikut santa 
Fransiscus, Aquinas menyebutnya jiwa-jiwa penggemukan. Aquinas menceritakan kisah perjalanan mulia St. Fransiscus yang memiskinkan diri dan bergabung bersama orang-orang miskin untuk menyebarkan ajaran Kristus di Mesir. Aquinas juga merasa kecewa dengan Dominican dan Fransiscan yang kini menggemukkan diri dari kekayaan gereja, bukan pahala mereka.

Aquinas juga memperkenalkan Dante dengan Raja Solomon. Ia adalah tokoh paling mulia di lingkup ini. Hal ini dikarenakan oleh kebijaksanaannya (yang diabadikan dalam al-kitab) saat Tuhan berbaik hati ingin mengabulkan apapun permintaan dia. Raja Solomon hanya meminta untuk ditunjukkan segala yang benar dan yang salah. Beatrice menarik Dante dan melanjutkan perjalanan. Kini mereka tiba di Mars. Tanah disini berwarna merah. Warna merah ini merupakan warna darah para crusader karena surga ini adalah surga para ksatria kristen. Mereka disambut jiwa-jiwa bersayap yang membentuk salib raksasa. Salah satu di antaranya mendekati Dante. Ia adalah nenek moyang Dante, Cacciaguida. Cacciaguida menceritakan kebesaran nama keluarga mereka di masa lalu. Ia juga menceritakan Florence yang damai di masa lalu tanpa tendensitendensi politik. Terakhir, ia memberi semangat agar Dante lebih bersabar atas kejadian yang menimpanya selama pengasingan dengan memperkenalkan ksatriaksatria crusader agung yang menempati surga Mars.

Beatrice, yang melihat Dante larut dalam kesedihan, menampilkan visi yang begitu mempesona sehingga Dante melupakan sejenak kesedihannya. Dante diangkat lagi menuju ke surga Jupiter, tempat para jiwa penegak keadilan. Disana ia begitu takjub pada jiwa-jiwa agung yang membentuk sebuah formasi elang, 
simbol keadilan dan kejayaan Romawi. Ia berdialog dengan sang elang raksasa itu. Sang elang memberitahu Dante bahwa sangat sedikit patriarch yang pernah melintasi surga ini karena mereka tergoda oleh kekuasaan yang akan menyesatkan mereka, diantaranya Frederick II, dan Charles of Anjou. Sang elang memperkenalkan beberapa nama yang membentuk Formasi elang. Bentuk yang menyerupai batu Ruby di kepalanya adalah Raja Daud, alis adalah Trajan of Rome dan Hezekiyah, matanya William II, dan Constantine, yang terakhir Ripheus of Trojan. Setelah mendengarkan ceramah darinya, sang elang pun memecah menjadi potongan-potongan kecil bersuka cita dengan menari, dan bernyanyi.

Perjalanan selanjutnya adalah surga Saturnus. Ia benar-benar tidak bisa lagi mengidentifikasi bentuk yang ada di hadapannya. Inderanya sudah tidak sanggup menangkap apa yang ada di surga ini. Namun tempat itu begitu hening tidak seperti surga-surga yang ia datangi sebelumnya. Penghuni surga, ternyata, sengaja melakukannya karena gendang telinganya pasti akan pecah mendengar mereka bernyanyi. Karena mendapatkan anugerah Tuhan, Dante akhirnya bisa melihat keseluruhan surga tersebut. Di sana ia melihat tangga emas dimana jiwajiwa yang bahagia turun bersama-sama menyambut Dante dengan sukacita. Surga ini adalah surga bagi para Pendeta yang menghabiskan hidupnya demi kristus, Disana ia bertemu St Benedictus.

Dante diizinkan menaiki tangga untuk tiba di surga rasi bintang tetap. Di Surga ini ia bertemu dengan Santa Peter. Dante akhirnya menyadari mengapa pertanyaan-pertanyaan dia begitu mudah dan langsung dijawab oleh Beatrice, dan 
penghuni-penghuni surga yang lain. Itu karena mereka bisa membaca pikiran Dante. Pikiran dan hati itu tampil dalam bentuk cermin, dimana cermin tidak bisa memantulkan segala sesuatunya dengan sempurna. Santa John dan Santa Peter mengetes Dante terkait tiga doktrin kristen Iman, amal, dan harapan. Setelah Dante menjawab dengan tuntas, ia dihadiahkan untuk bertemu dengan Adam. Dante mengajukan pertanyaan-pertanyaan mengenai sosok Adam yang misterius. Adam menjawab semuanya. Dante puas dengan pertanyaan tersebut. Beatrice pun mengangkat Dante ke pusat akal Tuhan, atap langit yakni premium mobile.

Premium mobile adalah surga tempat bersemayam para malaikat. Menurut Beatrice, di sini tempat dimana waktu diciptakan, dan digerakkan. Surga ini terdiri atas sembilan tingkatan yang diurutkan berdasarkan tingkat angelic intelegence. Ia juga mengutuk para filsuf yang sesat, mereka membuat diskursus yang lebih menekankan pada pertunjukan daripada memaparkan kebenaran. Mereka melanjutkan perjalanannya ke titik terakhir yaitu surga Empyren, tempat bunda Maria dan Yesus yang terbaring di pangkuan bundanya.

Di Empyren, Dante menyaksikan taman yang indah dengan sebuah cahaya Tuhan yang terang benderang menyinari taman tersebut. Beatrice meminta Dante meminum air dari mata air sungai itu agar melihat visi surga puncak dengan jelas. Berkat doa perawan Maria, Dante melihat sekuntum mawar yang sangat besar. Di puncaknya, duduk bunda Maria, dan masing-masing kelopak nya duduk orangorang suci, Jibril, dan juga Beatrice. Ia diizinkan membaca sebuah kitab Inkarnasi, rahasia alam semesta yang dijaga oleh kasih-sayang Tuhan. Tapi cahaya yang menyilaukan telah membuat ia lupa akan isi kitab yang sangat berharga itu. 


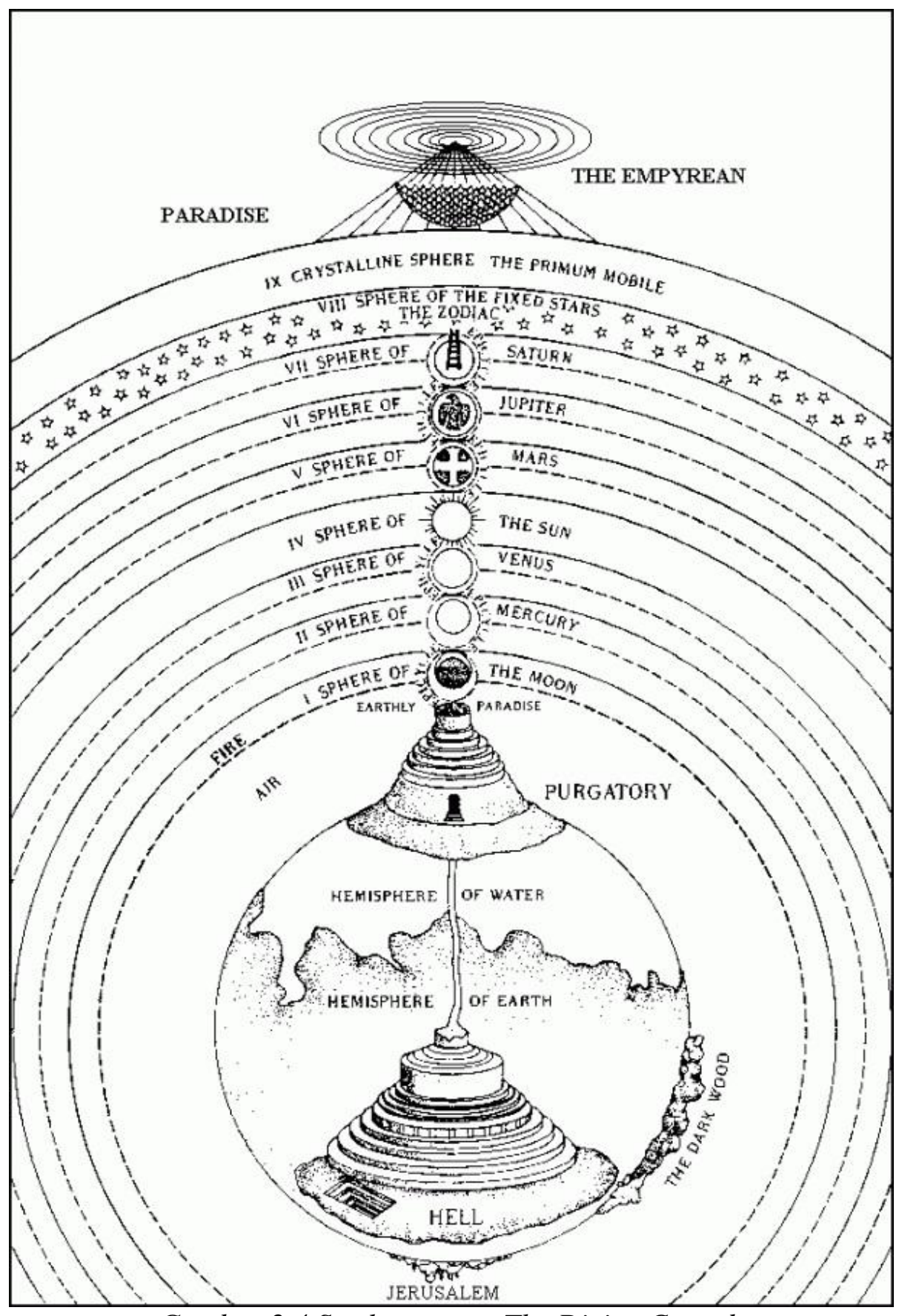

Gambar 2.4 Struktur surga The Divine Comedy 


\subsection{Strategi Perjumpaan dalam Teks}

Telah disebutkan berkali-kali di awal, puisi The Divine Comedy merupakan autobiografi Dante Alighieri bahkan ada yang menyebutnya sebagai autobiomitografi. Ini tidak bisa disangkal lagi, mengingat secara naratif pengarang berperan aktif sebagai protagonis dalam puisi ini. Ia berada di dua pos penting dalam bangunan teks, sebagai pengarang sekaligus tokoh yang sedang merekam kejadian-kejadian eskatoligis di sekitarnya. Dante menemukan suatu pengalaman unik yang diejawantahkan ke dalam puisinya. Ia mendikte kejadiankejadian, dan pengalaman di sekeklilingnya, lalu melaporkan apa yang disaksikannya, seperti seorang notulen perjalanan, sehingga dalam penelusurannya kemudian, pengarang tidak memberikan kesempatan bagi teks untuk diinterpretasikan secara liar oleh pembaca.

\subsubsection{Autobiografi; Kekangan terhadap Teks}

Dari pemaparan sub-bab sebelumnya, Dante melakukan suatu perjalanan yang belum pernah dijangkau oleh manusia-manusia fana sebelumnya. Perjalanan yang hanya bisa dilakukan orang-orang suci. Dengan puisi The Divine Comedy, dia membuktikan dirinya adalah bagian dari orang-orang pilihan tersebut, meskipun bukan mengambil bagian sebagai manusia suci, tetapi sebagai seorang pecundang sesat yang ingin dicerahkan melalui kuasa Ilahi.

“...

But I, why should I there presume? Or who permits it? Not Aeneas I, nor Paul..."

... "If right thy words

I scan," replied that shade magnanimous, "thy soul is by vile fear assail'd, which oft that he recoils from nobles resolution, like a beast 
at some false semblance in the twilight gloom.

(Inferno 2: 10)

["kecuali saya, mengapa saya yang harus membuktikannya? Atau siapa yang mengizinkan perjalanan ini? Padahal aku bukanlah Aeneas apalagi Paul..." "jika benar kata-katamu itu sama seperti apa yang kucerna" balas sang hantu yang pemurah "berarti jiwamu tengah dirundung rasa takut yang teramat akut. Rasa takut itu yang sering kali membuat seseorang menciutkan nyalinya untuk melakukan hal-hal terhormat, seperti berhadapan dengan bayang-bayang makhluk menyeramkan di kegelapan malam.]

Pengaruh metode logis aristotelian yang digunakan pada masa Medieval ini cukup kuat. Model silogisme kategoris memberikan pengaruh yang besar dalam membangun kepercayaan pembaca. Silogisme kategoris adalah suatu model logika berfikir dalam menarik kesimpulan. Penarikan kesimpulan rasional berdasarkan silogisme kategoris adalah dengan pola sebagai berikut; jika A menjadi B, dan B menjadi C, maka A menjadi C. Dari pola tersebut di atas, dapat disubstitusikan ke dalam kutipan di atas. Jika hanya orang suci yang bisa melakukan perjalanan menuju akhirat hidup-hidup, dan akhirat telah masuk ke dalam catatan perjalanan Dante, maka dapat disimpulkan bahwa Dante adalah bagian dari segelintir orang-orang suci tersebut. Apakah benar demikian? Tentu hal ini membutuhkan penelusuran lebih mendalam lagi.

Permainan silogisme Aristotelian seperti dalam kutipan di atas memberikan gambaran tentang dirinya yang bukan seorang suci namun berhak mendapatkan kesempatan melakukan perjalanan yang belum pernah dilalui oleh manusia. Ia memainkan reason sebagai sebuah logika untuk meyakinkan khalayak bahwa ia pantas mendapatkan posisinya, yakni sebagai manusia pilihan. Silogisme kategoris ini mencoba membongkar suatu pemahaman mengenai kepantasan 
Dante mendapatkan tiket berwisata ke alam akhirat. Jika disebutkan sebelumnya bahwa semangat era Medieval mendudukkan orang-orang suci/taat di tempat yang sangat tinggi, dimana mereka yang dimaksud adalah para Nabi, Wali, Paus, dan sebagainya, tidaklah layak seorang penyair yang menentang kuasa Paus Boniface VII ini mendapat posisi atau setara dengan posisi Wali Tuhan yang sudah disebutkan sebelumnya. Kata-kata mereka adalah sabda dan tindakan mereka adalah teladan.

Dante selanjutnya menggunakan permainan Silogisme kategoris Aristotelian untuk membongkar konsepsi tersebut. Ia menarik diri dengan menunjukkan bahwa dirinya bukan bagian dari orang-orang suci. Strategi selanjutnya, ia lalu mengawali dengan mempertanyakan terlebih dahulu reason sebagai bentuk permulaan retorisnya membuka jalan dalam mencari-cari kemungkinan adanya keretakan doktrin Kristen yang kaku dan kokoh tersebut mengenai persyaratan untuk orang-orang suci dan dia menunjukkan dirinya sebagai orang yang berbeda dari mereka.

Tidak selesai dengan itu, ia, sebelumnya, memunculkan satu kategori baru. Ini dilakukan sebagai fondasi untuk membangun negosiasi tingkat selanjutnya. Secara implisit ia ingin mengatakan bahwa ketika Dante bukan bagian dari golongan orang-orang suci, setidaknya masih ada kategori lain yang membuka kesempatan bagi dia untuk memenuhi persyaratan tour tersebut. Kategori di luar dari klaim suci. Kategori tersebut adalah kategori ksatria atau para pemberani yang membela kebenaran dan kaumnya. Alih-alih bergabung dengan kategori tersebut, Ia lalu membuat suatu pernyataan negasi dengan mengatakan dirinya 
adalah “not Aeneas, nor Paul..” Aeneas dan Paul adalah dua tokoh tangguh dalam mitologi Romawi karya Virgil.

Dengan memposisikan dirinya berada di bawah kedua nama tersebut, Dante sebenarnya sudah membangun pengecualian yang berlapis-lapis. Secara tersirat ia mengatakan selain orang-orang suci dan juga tangguh, Tuhan masih memberi kesempatan lain untuk mengikuti tour tersebut, sebagaimana yang didialogkan Virgil, yaitu orang-orang yang kehilangan harapan. Ketika perangkat premis-premis tersebut telah terpenuhi, maka kesimpulannya Dante-pun berhak untuk mengikuti touring tersebut. Padahal, doktrin Kristen sendiri mengenal konsepsi the three holy virtues (Purgatory 7: 171) yaitu faith, charity dan hope. Ketiga-tiganya, baik secara implisit maupun eksplisit, diceritakan telah menghilang dari dalam diri Dante. Virgil, berkata lain di baris selanjutnya namun tidak memberikan jawaban yang tegas tentang keterpilihannya.

Hal ini menarik untuk terus diekspolorasi mengingat reason tersebut bukan hanya terkait permainan silogisme yang dipaparkan sebelumnya, tapi tema yang ia usung, dan juga menelusuri sejauh mana Dante mempertahankan spirit religiusitas yang dia yakini, dan sejauh mana autobiografi ini bertahan pada kenyataan, ataukah dia berusaha keluar dari realitas dan bermain di ranah fantasi yang dalam hal ini adalah sesuatu yang belum pernah dialami manusia. Di barisbaris selanjutnya, masih canto yang sama, Beatrice memberikan abstraksi mengenai alasan mengapa Dante menjadi orang yang terpilih.

"I, who now bid the on this errand forth, Am Beatrice; from a place I come Revisited with joy. Love brought me thence, Who prompts my speech... 
In high heaven a blessed Dame

Resides, who mourns which such effectual grief

That hindrance, which I send thee remove,

That God's stern judgement to her will inclines.

To Lucia, caling, her she thus bispake:...

'Beatrice! Why is not thy succour lent

to him, who so much loved thee, as to leave

For thy sake all the multitude admires?

Dost thy not hear how pityful his wail,

Nor mark the death, which in the torrent flood,

Swoln mightier than a see, him struggling holds?'

Thus am I come: I saved thee goodly mount

Prevented. What is the comes o'er thee then?"

(Inferno 2: 11-12)

[Akulah Beatrice, yang selama ini berada di balik semua peristiwa yang menimpamu saat ini, juga penawaran tersebut; aku datang dari suatu tempat yang membuatku bersuka cita dan sedetikpun tidak ingin aku tinggalkan. Cintalah yang menuntunku ke tempat ini, dan memintaku untuk berbicara... Di atas sana, ada seorang Wanita mulia yang bersedih sehingga kedukaannya yang mendalam itu begitu bertuah, menyaksikan caraku mengujimu, untuk membawa engkau kemari. Tangisnya yang meringis menggegerkan nirwana, meretakkan ketetapan Tuhan agar berpihak padanya. Dialah Lucia. Ia lalu bersabda:... 'Beatrice! mengapa engkau diam saja, tidak memberikan sedikit pertolongan untuk lelaki yang mencintaimu, yang demi engkau ia rela meninggalkan segala yang ia miliki. Apakah kau tuli betapa mengirisnya ratapannya? Seperti maut yang tidak kunjung datang pada diri seseorang yang diterjang banjir besar dimana tangannya menggapai-gapai, mencari pegangan tapi tidak satupun sanggup menyelamatkan dirinya?'... lalu aku datang (seperti yang ia inginkan): menyelamatkanmu, menjauhkanmu dari hutan yang liar. Lalu mengapa engkau masih terpaku disini?"]

Dari dialog Dante, Beatrice, dan pihak lain yang dikenal sebagai wanita suci, bernama Lucia ini, dapat disimpulkan bahwa orientasi dari perjalanan mistik ini adalah dengan memanfaatkan grace, atau kasih sayang Tuhan. Ini diawali dengan effectual grief dari Lucia yang mampu menggoncangkan tatanan kuasa Tuhan, konon dalam doktrin agama samawi peristiwa tersebut hanya pernah terjadi di masa nabi Musa. Grace ini diuraikan lebih dalam lagi, bahwa grace 
timbul dari rasa iba yang mendalam salah seorang penghuni puncak surga setelah melihat penderitaan yang dialami Dante, saat diberi ujian oleh Beatrice.

Grace berhasil diplesetkan ke dalam pengertian yang berbeda dari doktrin kristen yang paten tersebut, apalagi telah disebutkan dalam kutipan di atas That God's stern judgement to her will inclines. Ini adalah celah bagi Dante untuk menciptakan alternatif kehendak-kehendak yang berada di luar dari sejarah doktrin Judea-christian yang pernah ada, atau dalam hal ini, Dante sudah berhasil berada di luar dari konteks Al-Kitab, bahwa Tuhan memiliki kehendak-Nya sendiri dengan memilih Dante. Namun yang terpenting dari itu semua, keterpilihan Dante itu terkait dengan pernyataan Beatrice "Love brought me thence..". jika kembali ke permasalahan awal apa yang menjadi alasan Dante menjadi orang yang terpilih, maka jawabannya adalah cinta. Bukan cinta Beatrice, tetapi cinta Dante terhadap Beatrice.

Menurut kutipan di atas, cinta Dante kepada Beatrice mampu menggetarkan langit, dan penghuni-penghuni surga turut berkonspirasi untuk meretakkan kehendak Ilahiyah mereka. Beatrice sendiri digambarkan tidak menginginkan untuk bertemu dengan Dante.

"I, ... Am Beatrice; from a place I come

Revisited with joy."

['Akulah... Beatrice; aku datang dari suatu tempat yang kurindukan kembali dengan suka cita (surga). "]

“...Revisited with joy” adalah satu pembatasan yang dilakukan oleh Dante bahwa syair-syair ampuh Dante, yang dikatakan sebelumnya mampu menggegerkan langit itu, tidak akan sanggup melumpuhkan perhatian Beatrice dari cahaya Tuhan 
yang Maha Indah. Ia tetap memposisikan dirinya sebagai manusia hina. Beatrice tetap menjadi jiwa yang mulia. Lucialah dalam hal ini yang menginginkan agar Beatrice segera menemui Dante.

'Beatrice! Why is not thy succour lent to him, who so much loved thee,..?'

Ini adalah suatu bukti bahwa dari strategi Dante menghadirkan motivasi yang berbeda sang Divine Mercy (Lucia), yaitu rasa iba, dan ketulusan cinta, dengan begitu Dante dapat leluasa menafsirkan pakem eskatologi Kristen yang kokoh ke dalam bait-bait puisinya kemudian. Karena cinta menjadi motivasinya, maka gerak perjalanan - yang dilakukan oleh protagonis tidak menunjukkan sebuah perjalanan spritiual tetapi perjalanan yang dimotivasi oleh cinta.

Di luar daripada itu, pemilihan alasan akan selalu dipandang rasional, selama mengikuti pakem-pakem proposisi yang telah ada, karena, meskipun beberapa di antara kasus di dalam Commedia tidak menggunakan prinsip silogisme, pengarang masih tetap menjadi tuhan atas teks yang ia buat sendiri.

Bangunan proposisi ini digunakan sebagai langkah awal untuk mereduksi keyakinan religius pembaca sebelumnya, dengan menyisipkan pengacualianpengecualian yang beralasan. Ini dapat disimpulkan bahwa silogisme merupakan strategi awal membangun kepercayaan pembaca. Saat pembaca terlena dan hanyut dalam pengantar yang logis dan memenuhi kriteria yang tepat, fantasi dan obsesi pengarang perlahan merasuk ke dalam sendi-sendi paradigma berpikir pembacanya. Pengarang, dengan kecanggihan teknologinya dalam merekayasa teks, melakukan pemlesetan-pemlesetan dalam interpretasi teks-teks suci. Dengan begitu, ia sanggup menaklukkan pembacanya, menarik simpati mereka, dan 
mendikte mereka melalui berbagai ekstasi dan juga ragam ketakutan dengan permainan silogisme tersebut.

Di samping itu juga, Ada beberapa kejadian di akhirat Dante yang tidak membutuhkan alasan tetapi hanya memberikan tausiyah semata, salah satunya yaitu kejadian sesaat setelah Dante selamat dari pengejaran pasukan Malacoda di neraka hypokrit. Diceritakan Dante dan Virgil bertemu pendeta-pendeta malang ynag mendapatkan sikaan di neraka, Virgil diberitahu oleh mereka bahwa jembatan yang merupakan jalan pintas yang dikabarkan rubuh oleh Malacoda ternyata masih utuh. Tidak ada alasan yang pasti apa motif Malacoda dan pasukannya menipu Virgil, kecuali untuk sebuah pesan.

\section{... "At Bologna erst}

I many vices of the Devil heard;

Among the rest was said, 'He is a liar,

And the father of lies!'”... (Inferno 23: 97)

["di masa lalu Bologna, aku mendengar begitu banyak keburukan tentang Iblis; di antaranya dikatakan, 'dia itu pembohong besar dan sumber dari segala kebohongan.]

dari kutipan di atas, tampak Dante tidak sedang bermain silogisme di poin ini. Dia tidak menunjukkan di dalam teks bahwa Malacoda ingin menipu, menjebak, atau membahayakan mereka berdua, tetapi dia ingin memberi sebuah hikmah secara implisit bahwa jangan pernah bersepakat, dan percaya pada iblis karena hal itu hanya akan berujung sia-sia. Virgil dalam kasus ini merasa menjadi korban kebohongan Malacoda, seperti tampak dalam teks berikutnya.

My leader with large stride proceeded on, Somewhat distur'b with anger in his look (Inferno 23: 97)

[tanpa menoleh sedikitpun pembimbingku melanjutkan perjalanannya, dari gerak-geriknya tampaknya ia tidak lagi mampu menyembunyikan kemarahannya] 
Setelah membahas sekelumit ke-otoritas-an Dante menuliskan The Divine Comedy, benarkah kemudian karya trilogi ini dipandang sebagai otobiografi? Menurut prof. Grandget (Elliot, Charless. W: 4, 1980) Commedia bukan hanya memuat autobiografi, tetapi berisi ensiklopedia, dan gradasi orang-orang yang Dante puji. Dante tidak menuliskan autobiografinya sebagaimana orang-orang lain menuliskan segala sesuatu tentang dirinya. Dante menuliskan commedia dalam syair-syair puisi yang apik. Dalam banyak baitnya ia memunculkan ikonikon tertentu untuk menggambarkan sesuatu yang lain. Salah satu contohnya saat ia merasa dirinya dikepung hewan-hewan buas, yaitu harimau, srigala betina, dan singa.

...Scarce the ascent

began, when lo! A phanter, nimble light,....

And by new dread succeeded, when in view

A lion came, 'gainst me....

... A she-wolf

was at his heels, who in her leanness seem'd...

(Inferno 1: 6)

[perjalanan yang langka inipun kuawali, namun tiba-tiba saja! Seekor harimau melintas dengan kecepatan kilat... dan kengerian yang lain menjemput, dari kejauhan seekor singa datang menghampiriku... tepat di belakangnya membuntutiku seekor srigala betina dengan tubuh yang kurus]

Penggambaran harimau, singa, dan srigala betina (lonza, leone, lupa) menurut Durling (1996: 36) tidak menunjukkan binatang yang sebenarnya. Binatangbinatang buas tersebut adalah kiasan dari dosa-dosa berbahaya (deathly sins) yang melekat dalam diri manusia. Tiga dosa berbahaya tersebut adalah nafsu (atau serakah) digambarkan dengan She-wolf, kekerasan yang digambarkan dengan 
Lion, dan Panther yang digambarkan dengan penipuan. Ketiga dosa ini adalah dosa-dosa yang mendapatkan hukuman yang keras di neraka Dante.

Ikon-ikon seperti yang disebutkan di atas merupakan alusi dari kenyataan hidup yang dihadapi Dante. Dalam canto yang sama, penanda a gloomy wood tidak benar-benar menunjukkan situasi sama persis yang dengan visi yang ditangkap pembaca mengenai hutan rimba, dan suasana mencekam. Menurut Durling, hutan rimba yang dipakai oleh Dante adalah situasi dirinya yang berada di tengah kesesatan dan dosa. Ia memainkan ikon-ikon lalu mengaburkannya dengan sedikit berteka-teka. Ini membuktikan bahwa Dante memberi kesempatan terhadap teks untuk sedikit liar dengan bermain metafora dan metonimi di dalam The Divine Comedy. Dante pun menyadari bahwa kata tidak akan sanggup menggambarkan realitas yang sesungguhnya sebagaimana kutipan berikut

Who, e'en in words unfetter'd, might at full Tell of.... That now I saw,

Though he repeated oft the tale? (Inferno 28: 114)

[siapakah, bahkan dengan menggunakan kata-kata liar, mampu mengungkapkan secara utuh apa yang kusaksikan saat ini, meski ia berusaha untuk mencoba menceritakannya secara berulang-ulang?]

Meskipun karya ini adalah sebuah autobiografi, menurut banyak peneliti, commedia menawarkan dimensi yang berbeda untuk menceritakan tentang dirinya dan kehidupannya. Dengan memainkan narasi, metafora, dan personifikasi, autobiografi Dante dalam hal ini The Divine Comedy tidak akan membuat puisi ini diklaim sebagai karya yang memuat tentang kebohongan. Karena telah dijelaskan sebelumnya bahwa tulisan tersebut adalah puisi atau merupakan luapan emosi pengarang dengan teknologi sastra yang canggih, maka karya ini terbebas dari benar atau tidaknya pengalaman tekstual yang dialami pengarang. Meskipun 
membuka ruang interpretasi, Dante menanamkan nilai yang sifatnya subjektif. Ia mengkotak-kotakkan manusia dengan semena-mena berdasarkan amarah dan ekstasinya sendiri tanpa memperdulikan pertimbangan yang lain.

Pengalaman inilah yang banyak peneliti menyebut The Divine Comedy sebagai autobiografi. Autobiografi berada di dalam otoritas pengarang. Pengarang memiliki otoritas untuk merepresi teksnya. Ia menciptakan totalitas makna. Di mata pengarang, teks berarti representasi dari pantauan dan pengalamannya. Dengan cara ini, makna menjadi terkapsulasi. Kehadiran autobiografi mendikte tanda. Hal ini disebabkan autobiografi seperti tak berjarak dengan diri pengarang, sehingga teks seperti menjadi bagian dari tubuh pengarang yang juga tidak bisa diacak dan dicacah.

Melekatnya kesadaran-diri di dalam autobiografi membuat teks tersebut menjadi mitos. Kebenarannya menjadi subjektif. Ini bisa menjawab permasalahan awal mengenai pertanyaan benarkah Dante sedang merilis laporan perjalanannya mengenai penelusurannya di dalam ruang eskatologi. Jika hal ini menyangkut autobiografinya (commedia), berarti ia sedang membangun mitos tentang dirinya, kebenaran, kejayaan, atau kebesaran dirinya sendiri. Makna-makna tunggal yang terhampar di dalam commedia, jika dikaitkan dengan pernyaaan sebelumnya, tidak lebih adalah makna yang sifatnya imajinatif, dan fantastik.

Ketika ia menggambarkan dirinya takjub, atau berlutut berarti ia memuji jiwa atau sosok terhormat tersebut di dalam kehidupan nyata. Ketika ia bersedih, ngeri, ketakutan, bahkan menceramahi sesosok jiwa berarti di alam nyata (di luar teks) ia menunjukkan rasa kasihan, marah, dan ketidakpuasannya pada jiwa-jiwa 
tersebut. Namun, telah disebutkan sebelumnya, bahwa Dante mempunyai teknologi imajinasi yang sangat tinggi. Ia memainkan penanda-penanda di dalam teks sehingga pembaca terpukau dan mengabaikan bahwa Logos (Tuhan) dari autobiografi yang memuat ruang eskatologi ini adalah Dante sendiri. Jika diperhatikan Inferno pada Canto 5, disana ada monster raksasa bernama Minos:

There Minos stands...:

he, of all who enter, strict examining the crimes,...

.... judge severe

of sins, considering what place in Hell

suits the transgression, with his tail so oft

Himself encircles, as degrees beneath

He dooms it to descend. (Inferno 5: 21)

[Di sana Minos bersiaga..: Dari semua yang masuk ke tempat ini, ia periksa dengan ketat, mengadilinya seberapa parah dosa-dosa mereka,lalu menimbang-nimbang neraka apa yang pantas untuk pelanggarannya, bersama ekornya yang panjang melilit di tubuh jiwa yang malang, tingkatan neraka yang ia (jiwa malang) tuju berdasarkan sebanyak jumlah lilitan ekor. Minos pun menghempas si ruh ke dasar neraka.]

Keistimewaan salah satu makhluk mitologi yang ada commedia ini, selain tubuhnya yang berwarna merah dan posturnya yang besar dan menyeramkan itu, ditambahkan dengan penciuman dosanya yang tajam. Hanya dengan sedikit kata dari terdakwa, lalu mengendusnya ia dapat mengenal dosa terberat si ruh yang malang tersebut. Dengan ekor yang panjang, ia melilitkan buntutnya itu ke tubuh si pendosa dengan jumlah lilitan yang disesuaikan dengan tingkat neraka yang akan dihuni selamanya oleh pendosa tersebut. Penyiksaan yang dilakukan oleh Dante terhadap teks juga sama yang dilakukan Minos terhadap pendosa. Ia tidak memberikan kesempatan menginterogasi pendosa, sebagaimana Dante lakukan terhadap teksnya. Dari semua peristiwa yang ada, dimulai dari pertemuan Dante 
dengan Virgil di glomy wood hingga membaca kitab Inkarnasi di Empyrean, ia hanya bertemu dengan jiwa/makhluk yang ia inginkan dan menempatkan mereka sesuai dengan keinginannya dengan bumbu reason yang cukup kuat. Minos adalah representase Dante di neraka, sebagaimana ia sendiri adalah Logos (pusat), dalam The Divine Comedy.

\subsubsection{Alegori; Alternatif Strategi Perjumpaan}

Alegori, menurut Oxford Dictionary, secara umum adalah sebuah cerita, puisi, atau lukisan yang diurai untuk mengungkapkan pesan yang tersembunyi di balik karya sastra/seni tersebut, biasanya berupa pesan moral atau pandangan politik tertentu (Oxford, 2008: 11). Dengan pengertian etimologis tersebut, alegori sendiri muncul sebagai strategi teks untuk menciptakan moralitas, dan mendidik. Alegori menurut pengertian tersebut di atas mirip dengan dongeng-dongeng fabel. Menurut Habib (2005: 213) Alegori adalah sebuah bentuk ekspresi verbal yang menunjukkan secara metaforis misteri di luar pemahaman manusia, lalu mengakomodasi inisiatif manusia secara terstruktur.

Sastra atau teks yang mengusung suatu inisiatif yang absurd, tidak serta merta mudah diserap, atau diyakini pembaca, pengarang memunculkan tokoh atau ujaran dari tokoh-tokoh yang yang bisa dijadikan saksi atas peristiwa imajinatif pengarang. Arus logika alegori dapat digambarkan sebagai berikut.

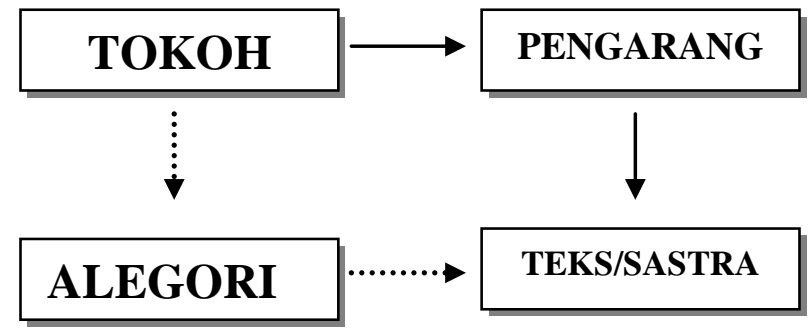




\section{Bagan 2.1 Pola alegori}

Dapat diperhatikan bahwa bagan di atas menunjukkan bahwa alegori secara eksplisit maupun implisit menghubungkan sosok yang mempunyai pengaruh besar terhadap pengarang ke dalam teks. Dari pola ini, teks/sastra terkesan menampilkan dua sosok, bahkan yang sangat primitif terjadi dialog dan saling mengomentari satu dengan yang lain, seperti dialog Timaeus dan Plato dalam Republic. atau Dante yang tengah asyik mendengar Homer melantunkan syair-syair indah di Inferno.

Pengarang dan tokoh alegori memiliki dua entitas yang berbeda. Keduanya bergumul dalam teks, lalu menciptakan dialektikanya sendiri, seakan-akan ada logos yang berbeda muncul di balik teks lalu terbenam lebih awal, kadang-kadang kehadirannya menaklukkan pengarang, kadang-kadang pula dipermalukan (baca: diprotes) oleh pengarang. Seperti pada Purgatory 4, secara implisit Dante menghadirkan pemikiran Plato di dalam puisinya. Melalui fakultas ilmu tentang jiwa yang dipahami Plato, ruh (baca: soul), menurut Plato, merupakan entitas hidup yang berjumlah banyak untuk menggerakkan satu tubuh manusia (Durling; 72, 2003). Dalam puisi tersebut, Dante mengatakan ... and thus the error is disproved which holds The soul not singly lighted in the breast (Purgatory 4: 157). Dante menolak pemikiran tersebut. Ia menyaksikan dengan mata kepalanya sendiri bahwa sesosok jiwa di gunung purgatory hanya akan mempertanggungjawabkan sebuah tubuh yang pernah hidup di dunia, yang berarti bahwa tubuh seseorang hanya dikendalikan oleh satu jiwa saja. 
Teks, oleh pengarang pada hakekatnya, tidaklah kokoh jika tidak ditopang oleh logos dari unsur yang lain. Logika alegori cukup kuat untuk membangun logos. Dalam kaidahnya, sebagaimana yang dapat dilihat di gambar 2.5, alegori mmempunyai peranan penting bagi pengarang menghadirkan logika yang lain. Pengarang tidak cukup hanya dengan mengedepankan dirinya sebagai penentu kebijakan terhadap teksnya. Silogisme kategoris lalu dikembangkan menjadi ujaran-ujaran, untuk mendukung teks. Dalam prinsip alegori, tokoh atau ekspresi verbal adalah perangkat silogisme dimana ketika tokoh tersebut menyampaikan suatu kebenaran atau kesaksiannya kepada pengarang, dan pengarang menyisipkannya ke dalam teks, maka teks itu menjadi benar. Alegori menjadi pos-pos penting dalam menguasai teks untuk tidak keluar dari ruang makna, filosofi, atau moralitas yang ditawarkan pengarang. Jika diilustrasikan ke dalam sebuah medan pertempuran, dimana teks bertemu dengan pembacanya, pengarang sudah bersiap-siap dengan mengerahkan pasukan-pasukan logisnya yang tangguh, yang dipimpin langsung oleh panglima-panglima berpengalaman, yakni alegori.

Seiring bertumbuhnya zaman, pengertian alegori telah berkembang sangat kompleks bahkan melampaui personifikasi dan metafora itu sendiri. Perkembangan pengertian dan pola alegori mengikuti spirit zaman pada masa tersebut. Salah satu contoh, Pada masa perkembangan sastra realisme, model alegori digunakan sebagai jalan untuk menggambarkan kondisi yang lebih natural. Ini dapat dilihat dari puisi William Collins (1746) yang berjudul the Passion. Ia menyebutkan beberapa benda, merepresentasikan hasrat atau metafora tokoh tertentu, dengan mengawalinya dengan huruf kapital. Kapitalisasi benda/sifat 
tersebut menyiratkan nama-nama figur yang mengasosiasikan hasrat ke dalam Alegori. Terkait dengan novel Dickens yang berjudul Great Expectation (1861), tokoh Mr Wopsle, menurut Tembling (2007: 12) adalah wujud personifikasi dari tindakan-tindakan yang dalam The Passion, setelah Dickens mengklasifikaasi hasrat-hasrat tersebut ke dalam gender maskulin, seperti Thunder, Revenge, dan War. Lalu Mrs. Siddon adalah mengalegorikan keadaan emosional seperti Envy, dan Anger.

Dari Ilustrasi di atas, strategi alegori mengalami perubahan yang signifikan, yang tidak lagi berpatokan pada ujaran atau ekspresi verbal dari sosok tertentu. Alegori hadir untuk memberikan penguraian atas maksud-maksud metaforik dari kebendaan tertentu. Seiring waktu berjalan, Alegori tidak lagi menunjukkan pendikteannya yang berlebihan di dalam karya sastra. Gaya bahasa ini hadir bukan lagi untuk memaksakan sikap moral pengarang ke dalam teks, tetapi menunjukkan keprihatinannya terhadap kondisi sosial masyarakat yang terjadi di zamannya. Namun, posisi alegori tersebut tentu akan berbeda jika ditarik ke era yang lebih primitif, era Medieval.

Di awal kelahiran model permainan bahasa ini, yaitu di era Yunani kuno, Alegori mempunyai karakter penting dalam meramu ilmu, filsafat, ajaran, dan karya seni. Karya besar Plato, Timaeus, adalah salah satunya. Plato, dalam karyanya itu, bukan hanya mereproduksi dan mengomentari buah pemikiran Timaeus yang berjarak kurang lebih satu milenium dari masa Plato itu, tetapi juga memainkan alegori ke dalam sebuah dialog, dimana mereka berdua saling berdiskusi tentang pemahaman mereka satu sama lain. Republic Plato menjadi 
karya filsafat yang agung sepanjang masa yang juga secara bersamaan menyimpan mistifikasi atas diri serta karyanya itu. Karya-karya Yunani Kuno terutama di bidang sastra seperti Homer, dan Romawi Kuno seperti Virgil, Lucan, Ovid, dan Horace, selanjutnya banyak mengikuti gaya alegori tersebut untuk menjaga ruh mistik dan estetika karya sastra.

Pada masa Medieval, selain memiliki fungsi mistik, Alegori juga merupakan jalan untuk membaptis tokoh-tokoh legenda pagan, dan mitologi ke jalan Kristen. Walaupun tidak ditanggapi seekstrim teks-teks Yunani, alegori di era Romawi klasik telah menjadi sebuah strategi teks untuk menginterpretasikan karya-karya agung, dan pemikiran tokoh-tokoh di masa lalu. Strategi tafsir ini pertama kali dirumuskan oleh Cartius. St. Paul memberikan contoh interpretasi perjanjian Lama melalui gaya alegori, yang berjudul Allegoresis. Karya ini menjadi rujukan bagi pengarang-pengarang relijius era Medieval dalam menafsirkan. Agustinus (2007) dalam tulisannya On Christian Doctrine (3. 10, 15, $426 \mathrm{M})$ membuka proyek penafsiran alegoris dengan mengatakan Alkitab tidak mengajarkan apa-apa kecuali amal, juga mengutuk apapun kecuali keinginan besar, dan oleh karena itu apapun yang hadir dari Firman Tuhan yang benar-benar tidak berhubungan dengan perilaku saleh atau kebenaran iman haruslah engkau urai ke dalam figuratif. Figurasi adalah langkah besar dalam mereduksi cerita rakyat dan mitologi pagan ke dalam kisah-kisah atau penokohan di dalam naskahnaskah religius masyarakat abad pertengahan.

Naskah-naskah Pagan hingga abad ke-14 masih digemari oleh masyarakat Eropa, terutama Itali. Oleh karena itu, untuk mencerap naskah-naskah agung 
tersebut ke dalam The Divine Comedy secara khusus dan teks-teks sastra Kristen bergaya medieval secara umum pada saat itu, Dante memberikan proyeksi sendiri mengenai alegori. Dia memperkenalkan terma empat lapis alegori. Yang pertama ia sebut dengan makna literal. Makna literal dimaksudkan adalah dimana sebuah nama kata, atau benda hanya memberikan suatu kesan tentang sebuah nama tanpa menstimulasi pembaca untuk melakukan penelusuran lebih dalam; yang kedua disebut dengan makna alegorik. Sebuah nama, seperti dalam kisah-kisah fabel, secara eksplisit maupun implisit dapat diketahui mampu mewakili kelompok tertentu, atau menyuarakan kelompoknya sebagai bagian yang lebih besar.

Yang ketiga disebut dengan kesan moral. Pada tahap ini, sebuah figur atau ujarannya bukan hanya mewakili kelompoknya, tetapi mampu mempertontonkan karakternya, sebagaimana menceritakan kisah srigala dan domba di hadapan anakanak, masing-masing tokoh memiliki nilai yang mesti dipetik untuk pembaca. Kesan ini harus memisahkan secara tegas antara kebaikan dan kejahatan, atau kesetiaan dan penghianatan, kebenaran dan kesesatan dan seterusnya. Alegori, sebagaimana dikatakan sebelumnya, Dante tidak memperkenankan kehadiran moralitas di wilayah abu-abu;

Dan yang terakhir, makna anagogik. Anagogik merupakan kunci utama dalam alegori Dante. Makna anagogik adalah nilai spiritual yang ditanamkan di dalam cerita bahwa semua perjuangan protagonis atau kebaikan harus dilandasi firman Tuhan karena dengan mengikuti jalan-Nya, ia akan menemukan kejayaan abadi (Habib, 2005: 211). Lapis ke empat inilah yang menjadi tujuan Dante. Karya-karya pagan yang begitu disenangi masyarakat Romawi Kristen karena 
berisi nilai kehormatan, keperkasaan dan mencerminkan kepahlawanan. Tentunya bagi penyair-penyair kristen sekaligus tradisionalis akan prihatin jika mitologi yang telah mengakar di tengah masyarakat dan menjadi ciri kebesaran bangsa mereka itu harus tergerus oleh kisah-kisah di dalam Al-kitab. Dari keprihatinan ini, Dante dengan brilan menawarkan lapis keempat sebagai bentuk negosiasi antara kisah-kisah paganisme yang cita rasa estetikanya sangat tinggi dan kisahkisah Al-Kitab yang menawarkan kebaikan dan pencerahan. Dalam pada itu, commedia hadir sebagai bentuk penerapan prinsip anagogical yang ditawarkan Dante.

Dalam perjalanan panjangnya menelusuri alam eskatologi, Dante pun meminjam tubuh Virgil dalam teksnya. Ada beberapa faktor yang menjadi keunggulan Virgil dibandingkan tokoh-tokoh yang lain pada saat itu. Pertama, ia adalah seorang penyair besar asal Mantua Italia. Karya agungnya Aenead memberikan kontribusi berharga bagi rakyat Itali untuk meneladani kejayaan, kegagahan, dan kebangkitan nenek moyang mereka di kerajaan Troy pasca ditaklukkan oleh Yunani. Ia dengan petualangan Aeneas-nya dalam menemukan negeri yang dijanjikan, berusaha menandingi kisah heroik Odyssey karya Homer yang mencari jalan pulang ke negeri tercintanya. Dengan adanya Aenead karya Virgil, kerajaan Romawi terkhusus Italia akhirnya memiliki sejarah yang panjang, yang terus menerus direproduksi untuk membangkitkan nasionalisme rakyat Italia.

Yang kedua, bangsa-bangsa di Eropa sangat rasial, terutama di wilayah kebudayaan. Bukan hanya karya sastra, dalam khasanah bahasa dan tata-krama, 
Romawi atau Italia masih berada di level bawah jika dibandingkan Yunani ini dapat dilihat pada kutipan Inferno berikut.

"..Thy tongue refrain: to question them be mine;

...For I divine thy wish; and they perchance,

for they were Greeks, might shun discourse with thee" (Inferno 26: 108)

["..lisanmu membendung begitu banyak rasa penasaran, kali ini aku yang akan bertanya tentang segala yang kau penasarankan; aku telah memiliki mukjizat untuk mengetahui apa yang ada dalam benakmu, dan mungkin saja mereka menghindar setelah mendengar kata-katamu. Mereka berdua adalah orang Yunani.”]

Menurut catatan kaki Elliot (1980: 108), kalimat terakhir dari kutipan di atas mengimplikasikan dua hal yaitu; arogansi bangsa Yunani yang lebih high secara kebudayaan dibandingkan bangsa Romawi yang masih terbilang baru; atau kerendah-dirian pengarang-pengarang Romawi jika dibandingkan dengan Pengarang Yunani Kuno. Hal ini dapat berasumsi bahwa jika Dante mengangkat tokoh Yunani sebagai guide-nya, selain menurunkan derajatnya sebagai pengarang, ia juga mengurangi nasionalisme dirinya sebagai bagian dari bangsa Italia atau Romawi di dalam karyanya itu.

Yang ketiga, Virgil memiliki satu keistimewaan dibandingkan pengarangpengarang sezaman dan sebelumnya di mata Dante. Keistimewaan itu adalah karena Virgil adalah pengarang yang telah menuliskan secara detil dunia bawah di dalam teks Aenead, lengkap dengan makhluk-makhluk mitologi yang hidup di dalamnya. Ini adalah perjumpaan yang menarik bagi Dante untuk mendiskusikan dengan Virgil baik secara implisit maupun eksplisit mengenai dunia bawah ala seorang pagan, dan neraka ala seorang kristen yang taat. Di sisi lain, Virgil bagi Dante cukup mewakili spirit mitologi dan sastra yang dikembangkan oleh 
penyair-penyair sebelumnya Dari ketiga faktor tersebut, terpilihlah Virgil yang menjadi guide Dante menelusuri alam setelah kematian tersebut.

Virgil adalah jembatan bagi Dante untuk mengurai fantasinya yang gila. Bukan hanya sebagai sebuah inspirasi tetapi juga sebagai implikasi pembenaran logika yang ia pahami. Dante menjadi dalang yang menggerakkan pikiran Virgil untuk mengamini apa yang menjadi ide, dan keyakinan Dante. Virgil mengetahui banyak hal, melalui karya-karyanya, lalu pengetahuan ini, oleh Dante, dimanfaatkan dengan rapi dengan menstrukturasinya ke dalam narasi dan gradasi kebaikan yang sesuai dengan apa yang pengarang (Dante) inginkan. Virgil dalam commedia ditugaskan untuk menuntun Dante, mengajarkan kebaikan, serta memberikan penjelasan mengenai apa saja yang tidak diketahuinya dan yang tampak di hadapannya. Masyarakat Italia, yang menggemari karya-karya Virgil, secara diam-diam membenarkan bahwa Virgil sangat memahami dunia bawah, dan pantas menggurui Dante untuk persoalan yang demikian.

Namun, di gunung purgatory, ini tampak berbeda. Virgil banyak terdiam. Ia lebih membiarkan Dante dengan petualangannya, seta menginterogasi tokohtokoh yang ia temui. Hal ini dapat dimaklumi mengingat St Peter gate, bagi calon penghuni surga yang akan disucikan, adalah gerbang yang merupakan visualisasi dari kitab suci. Virgil di gunung purgatory tampak hanya sekali memberikan ceramahnya, yang cukup kontras dengan pengetahuannya yang lebih tentang neraka. Ia menjawab pertanyaan filosofis mengenai hubungan jasad dan ruh di Purgatory canto 25. Penjelasan filosofis inipun dibantu oleh guidenya yang lain, Statius. Penjelasan ini tidak lebih disebabkan oleh pengalaman kematian yang 
membuat kedua penyair pagan tersebut mampu menjawab pertanyaan seputar dunia setelah kematian dan alam penyucian. Dari Virgil, Dante mengembangkan alegori secara luas.

Di surga, satu-satunya harapan Dante untuk dituntun adalah Beatrice. Selain motivasi romantisisme, sebagaimana disimpulkan di awal bahwa ia merupakan spirit di dalam The Divine Comedy, Beatrice juga memiliki keistimewaan di antara ratusan alegori yang dimainkan Dante. Ia adalah sosok yang tidak dilirik dalam sejarah. Keluarga dan suaminya bukan berasal dari tokoh politik yang bertikai. Ia tidak memiliki pengaruh apapun. Dan yang paling penting, Beatrice bukan tokoh yang dikenal. Ini celah bagi Dante untuk mencipakan dalih yang lebih bebas tentang keutamaan Beatrice di antara yang lain. Yang tidak kalah pentingnya adalah karena Beatrice mati muda. Ia, bagi Dante, tidak tercemari oleh dosa dan perhelatan politik yang terjadi di Florance. Dia layak menempati puncak Empyren.

Sebagaimana yang telah diurai di awal, kebenaran atau logos yang dimainkan secara alegori adalah cara yang brilian untuk memplesetkan realitas. Pola alegori yang secara sederhana menekankan bahwa not I, but spakes he (purgatory 6: 165) adalah strategi bagi pengarang untuk menaklukkan realitas dan moralitas menjadi miliknya. Oleh karena itu, tokoh sangat berperan penting dalam penegasan Logos. Mereka dilibatkan secara aktif dalam teks untuk membenarkan penilaian pengarang akan realitas yang ia proyeksikan.

Berikut ini adalah bagan jumlah dan kategori tokoh yang dialegorikan di dalam The Divine Comedy. 


\begin{tabular}{|c|c|c|c|}
\hline No & Kategori & Satuan & Jumlah Tokoh \\
\hline 1 & Total & - & 600 tokoh \\
\hline \multirow[t]{3}{*}{2} & \multirow[t]{3}{*}{ Gender } & Laki-laki & 515 tokoh \\
\hline & & Perempuan & 63 tokoh \\
\hline & & Netral & 24 tokoh \\
\hline \multirow[t]{3}{*}{3} & \multirow[t]{3}{*}{ Alegori } & Manusia & 513 tokoh \\
\hline & & Mitologi pagan & 62 tokoh \\
\hline & & Tokoh Al-kitab & 25 tokoh \\
\hline \multirow[t]{2}{*}{4} & \multirow[t]{2}{*}{ Penampakan } & Eksplisit & 583 tokoh \\
\hline & & Implisit/Simbolik & 17 tokoh \\
\hline \multirow[t]{4}{*}{5} & \multirow[t]{4}{*}{ Terhukumi/Selamat } & Neraka & 139 tokoh \\
\hline & & Purgatori & 43 tokoh \\
\hline & & Surga & 77 tokoh \\
\hline & & Tidak Terhukumi & 341 tokoh \\
\hline
\end{tabular}

Tabel 2.1 Tabel alegori The Divine Comedy

\subsubsection{Sistem Tertutup dan Hirarki}

Pemusatan pada bunyi, yang diistilahkan oleh Derrida sebagai fonosentris, dalam kasus commedia begitu berlapis. Teks ditopang oleh kehadiran-diri pengarang yang sangat tegas mendikte, ditambah alegori yang memainkan fungsi kesaksiannya sebagai tiang penyangga kehadiran tersebut.

Mekanisme kerja akhirat yang dijelaskan dalam teks commedia sebagian besar telah dipaparkan di atas. Mekanisme ini bergerak secara hirarkis dimulai dari Pusat hingga ke titik yang terjauh/hina. Subjek yang disokong oleh subjek- 
subjek lainnya, dalam model alegori, menyusun struktur realitas yang sistematis, dan tertutup. Ruang idealitas kitab suci yang absurd mengenai akhirat diutuhkan sedemikian rupa, dengan phone yang dibangun dari biografi dan alegori. Sifat tertutup ini serupa dengan mekanisme kerja linguistik Saussure. Perkawinan Konsep dan Citra akustik merupakan dasar dari terbentuknya bahasa. Penanda memiliki relasi tertutup dengan petanda. Sistem tertutup ini diistilahkan dengan difference. Telah dijelaskan di bab sebelumnya bahwa, menurut Saussure, bahasa adalah sebuah relasi, lalu dilanjutkan oleh Derrida, relasi tersebut adalah relasi yang bersifat hirarkis.

Sifat tertutup atau difference ini pula dapat dilihat dalam teks Inferno Dante. Sesosok jiwa, apabila dilempar dengan ekor Minos ke salah satu wilayah neraka, maka sampai hari kiamat, dalam hal ini dapat diterjemahkan dengan selamanya, jiwa itu tidak akan pernah berpindah lagi ke ruang neraka yang lain. Berikut ini salah satu contoh tertutupnya setiap level hirarki di commedia

"Briefly ye shall be answer'd. When departs The fierce soul form from the body, by itself Thence torn asunder, to the seventh gulf By Minos doom'd, into the wood it falls, No place assign'd, but wheresoever chance hurls it; there sprouting, as a grain of spelt, It rises to a sapling, growing thence A savage plant. The harpies, on its leaves Then feeding, cause both pain, and for the pain A vent to grief. We, as the rest, shall come for our own spoils, yet not so that with them We may again be clad; for what a man Takes from himself it is not just he have. Here we perforce shall drag them; and throughout the dismal glade our bodies shall be hung, Each on the wild thorn of his wretched shade" (Inferno 13: 55-56) 
["Aku akan menjawabnya dengan singkat. Saat jiwa berpisah dengan tubuh atas keinginannya sendiri, Minos memutuskan untuk melemparnya ke lapis neraka ke tujuh, hingga ia terjatuh di tengah hutan kayu, tidak ada tempat yang jelas buat mereka. Namun, kemanapun ia terhempas (selama menyentuh pohon dari hutan kayu), dari sela-sela jarinya mulai tumbuh ranting yang bercabang-cabang seperti sebutir biji kecambah yang terus tumbuh menjadi pohon muda, lalu menjadi tumbuhan yang mengerikan. Burung-burung harpy memakan daun-daun kami dengan lahapnya, yang bukan hanya menciptakan rasa sakit yang luar biasa, tetapi juga melampiaskan rasa sesal yang teramat dalam. Kami, sebagaimana jiwa-jiwa yang lainnya, kelak akan mengenakan kembali tubuh kami (di hari pembangkitan), tapi tidak dengan kami. Untuk apa sebentuk jiwa (bunuh diri) merindukan tubuh yang tidak ia ingin miliki lagi. Di sini nanti terpaksa kami harus menyeret tubuh-tubuh kami; dan seluruh jiwa di tengah rawa ini akan mengait jasad-jasad mereka, pada setiap duri rantingnya yang liar."]

Dari pengakuan Jacopo Da Santo Andrea, alegori seorang pelaku bunuh diri, tersebut di atas, dapat digeneralkan bahwa seorang pendosa akan mendapatkan konsekuensi atas tindakannya yang paling buruk. Hal ini juga terjadi di kantung-kantung neraka yang lain, dengan catatan bahwa masing-masing neraka memiliki teknik penyiksaannya sendiri. Pelaku bunuh diri, sebagai contoh, disiksa dengan menjadi pohon. Dari sela-sela jarinya tumbuh dedaunan. Dedaunan ini akan dimakan oleh burung mitologi Harpy, serupa elang dengan tubuh yang besar yang suka memakan dedaunan. Setiap daun yang dimakan burung-burung ini memberi sensasi sakit yang berlipat ganda bagi pemiliknya “..cause both pain, and for the pain A vent to grief..".

Disini pula dijelaskan, ketika Minos melempar jiwa-jiwa malang ke suatu kantung di neraka, mereka tidak akan lagi berpindah ke kantung neraka yang lain sampai hari kebangkitan tiba.

...We, as the rest, shall come for our own spoils, yet not so that with them We may again be clad; for what a man 
Takes from himself it is not just he have...

Potongan bait di atas merupakan contoh bahwa siksaan kubur (neraka) yang mereka terima tidak akan menghapus dosa-dosa mereka. Jiwa-jiwa malang ini mendapat siksa kubur untuk menunggu kedatangan hari kebangkitan (kiamat) tiba. Dalam penjelasan ini, mengisyaratkan bahwa mereka hidup abadi di distrik nerakanya masing-masing tanpa pernah bercengkrama, migrasi, atau bertukar tempat dengan penghuni distrik neraka yang lain. Sama persis dengan mekanisme difference dalam menghadirkan makna. Dapat dikatakan jika dalam bahasa satu makna mengimplikasikan satu citra akustik, maka dalam neraka Dante sebuah dosa mengimplikasikan satu ketakutan.

Kedekatan ini pula dapat dilihat dari kesemena-mena relasi, sebagaimana penanda memiliki hubungan yang semena-mena dengan petanda. Kadar dosa (pendosa) dan siksaannya (kantung neraka) memiliki juga hubungan arbitrer oleh pengarang. Dante mengaturnya sedemikian rupa, bedanya ke-arbitreri-annya ditopang dengan alasan agar tampak seakan-akan memiliki hubungan yang simbolik dengan Al-Kitab, dan juga merujuk pada peristiwa besar yang terjadi di zamannya. Jilid Inferno canto XIX, sebagai contoh, mengilustrasikan neraka bagi pelaku penerima suap. Penyiksaan di neraka ini digambarkan dengan tubuh pendosa yang tertancap di tanah dalam keadaan terbalik, dengan liang tempat jiwa-jiwa pendosa itu tertancap mirip bak pembaptisan bayi. Siksaan ini tentunya beralasan. Secara simbolik Dante ingin menyampaikan kritik kerasnya terhadap Paus yang mendukung dan mempraktekkan penjual-belian Indulgensi. Relasi kadar dosa dan siksaan merupakan bagian dari estetika komedi Dante yang 
bersifat tertutup, sehingga mekanisme siksaan menjadi tertata sangat rapi dan tidak memberikan kesan ambivalen di antara keduanya.

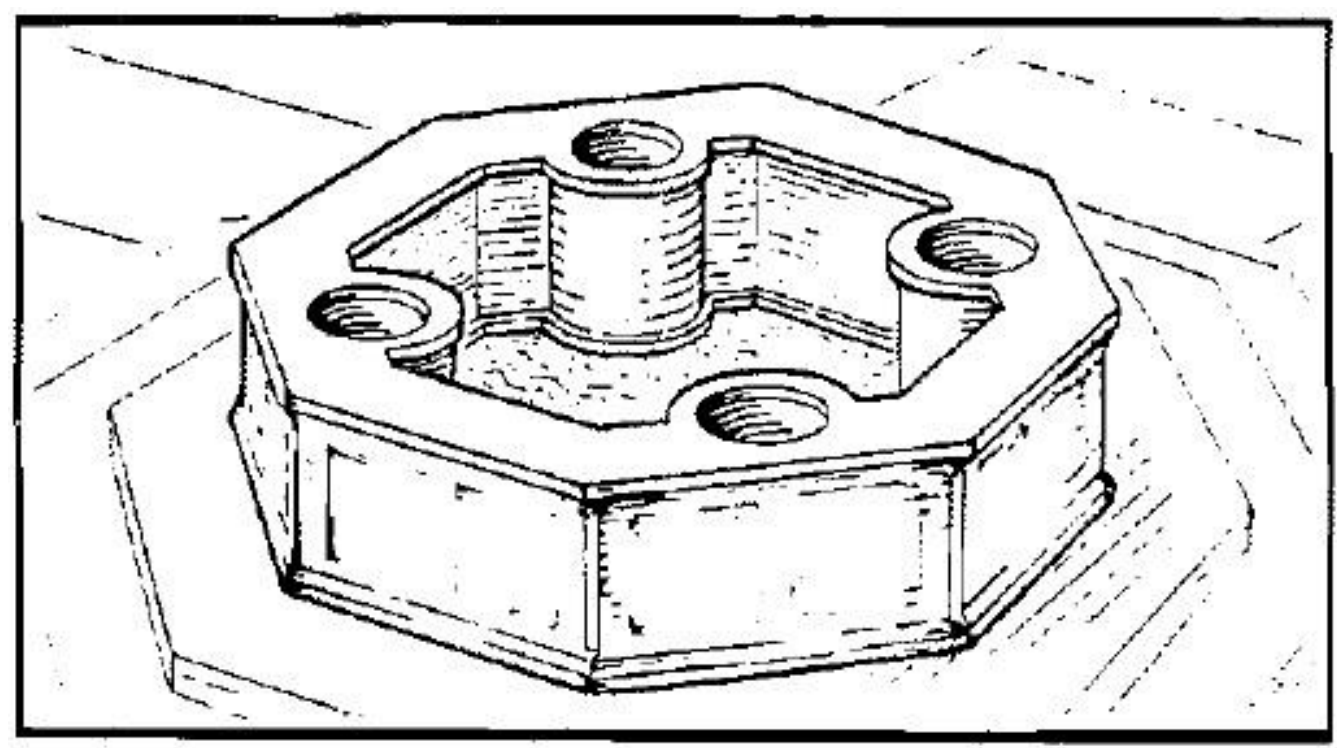

Gambar 2.5 Bak pembaptisan di geraja Pisa era Medieval

Hal yang sama terjadi di surga. Paradiso, jilid ketiga Commedia, juga memberikan sinyal mengenai mekanisme sistem hirarki surga yang tertutup. Seperti yang digambarkan pada paradiso canto 3, Piccarda harus bersyukur kepada Tuhan, walaupun ditempatkan di lantai surga terhina selamanya disebabkan terpasung oleh inkonsistensi dalam berjanji yang membuatnya menjadi pecundang dalam menjalani hidup, karena itu keputusan Tuhan yang tidak bisa ia ganggu gugat.

Hirarki tertutup, jika diperhatikan dengan seksama, pada dasarnya juga terjadi di alam purgatory. Secara eksplisit di alam ini jiwa-jiwa bergerak sebagaimana dijelaskan di inferno canto 4, bahwa jiwa-jiwa yang telah dibaptis akan melewati St. Peter gate untuk selanjutnya dicuci di alam ini dari sifat-sifat 
yang merusak dirinya sebelum terbang menuju surga. Di alam ini dijelaskan juga bahwa jiwa-jiwa harus melewati tujuh pos penyucian dan setelah itu mereka diminta meminum air dari sungai Styx untuk membersihkan kenangan yang mengikat mereka selama hidup di dunia. Pendosa akan berjalan dari satu pos ke pos yang lain hingga tiba puncak gunung Purgatory. Lebih detailnya berdasarkan teks The Divine Comedy, seorang pendosa, sebelum melangkah ke ruang pencucian, keningnya ditandai dengan huruf " $P$ " sebanyak tujuh kali oleh malaikat Michael.

\section{... Seven times}

The letter $(P)$, that denotes the inward stain,

He, on my forehead, with the blunted point

Of his drawn sword, inscribed. And "Look" he cried,

"When enter'd, that thou wash these scars away" (Purgatory 9: 182)

[Ia mengukir, dengan bekas yang dalam, tujuh kali huruf $(P)$ tepat di keningku menggunakan ujung pedangnya yang tumpul. Lalu ia berkata "Perhatikan, bahwa luka ini akan engkau bersihkan, saat masuk (ke gerbang ini)]

Dari kutipan di atas sangatlah jelas bahwa aktivitas penghuni atau arwah-arwah yang melintasi gunung Purgatory itu bergerak dari bawah menuju ke atas yang ditandai dengan berkurangnya satu demi satu huruf " $P$ " yang ada di kening mereka.

Dalam perjalanannya menelusuri Purgatory, Dante, seharusnya, akan mengalami dua hal. Pertama, Dante, selain Virgil dan dirinya sendiri, akan menemukan sosok-sosok yang dibersihkan lebih dari sekali. Hal ini disebabkan setiap pos penyiksaan mmbutuhkan kurun waktu yang sangat panjang, bisa 
mencapai berpuluh-puluh tahun, meskipun dijelaskan di Purgatory canto 23 bahwa sebuah dosa atau penyiksaan akan dipercepat prosesnya jika keluarga dan kerabat mereka yang masih hidup selalu mengirimkan mereka doa untuk mereka di gunung Purgatory. Jika dalam sebuah pos penyucian dosa ia bertemu dan berbincang dengan seorang tokoh yang telah menyelesaikan penyucian dosanya, lalu berangkat lebih awal mendahului sang penyair, semestinya ia akan bertemu sang arwah di pos selanjutnya. Hal ini disebabkan karena Dante, untuk tiba di pos selanjutnya, hanya memakan waktu perjalanan satu sampai dua bulan yang ditandai dengan pergantian rasi bintang.

Kedua, Dante seharusnya akan menemui arwah-arwah yang dengan latarbelakang dosa yang berbeda-beda di satu tempat, meskipun mereka di satu pos penyucian akan disiksa untuk dosa yang sama. Ini disebabkan arwah-arwah ini hanya sebuah kebetulan berada di tempat yang sama ketika Dante tengah bersiarah di tempat tersebut. Dalam hal ini, ketika Dante sedang berkunjung di pos Lustful, bukan berarti penghuni pos tersebut adalah orang-orang yang cabul saat mereka masih hidup. Mereka hanya menjalani suatu proses penyucian dosa untuk menghilangkan bekas huruf $P$ yang tersisa di kening mereka.

Namun kedua prediksi tersebut tidak demikian. Ada beberapa hal yang bertolak belakang mengenai alam Purgatory ini, yaitu ditemukannya banyak orang-orang kristen, pendeta, dan bahkan beberapa paus, yang notabene mereka telah dibaptis dan seharusnya telah berada di St Peter gate, ternyata mengalami penyiksaan yang sangat keras, dan tentu saja abadi di dalam neraka. Ini adalah fakta lain bahwa Dante menempatkan tokoh-tokoh dalam The Divine Comedy 
bukan berdasarkan pada tingkatan atau derajat kesucian atau kehinaan perbuatannya di muka bumi, tetapi pada seberapa besar cinta, terhormatnya, dan terkutuknya mereka di mata pengarang.

Yang janggal mengenai alam ini juga adalah orang-orang yang ditempatkan di alam ini adalah orang-orang semasa hidupnya melakukan tindakan atau bersikap yang konsekuensinya sesuai dengan hukuman yang mereka peroleh di alam Purgatory. Dapat dilihat di Purgatory canto 4, Belacqua adalah tokoh yang ditemukan Dante tidur bermalas-malasan bersama kawanan yang lain. Di tempat ini, mereka memiliki kesamaan perasaan yaitu perasaan putus asa karena merasa dosa-dosanya tidak terampuni. Alih-alih bervariasi sebagaimana dijelaskan di atas, jiwa-jiwa malang ini berkumpul dengan nasib dan juga tingkat kesalahan/dosa yang sama.

Di salah satu pos di Ante-Purgatory yang dinamai The Negligent Rules, Purgatory Canto VII, tergambar tokoh-tokoh Patriarkh yang tidak bisa melanjutkan perjalanan karena tertahan oleh warisan-warisan berupa anak-anak, atau pewaris tahta yang tidak sanggup memimpin negerinya karena mereka tidak sempat mengajarkan kebaikan kepada pewaris negerinya. Bukti lain tertutupnya sistem di alam Purgatory adalah tokoh yang bernama Omberto dalam Purgatory canto 11. Bentuk pencucian dosa di pos Kesombongan ialah dengan memikul batu gunung yang besar dan juga sangat berat di punggungnya sehingga jiwa-jiwa yang melewati pos ini berjalan membungkuk. Diceritakan di pos ini Dante bertemu dengan salah seorang tokoh ternama di Siena, Omberto. Omberto memperkenalkan dirinya dengan begitu berlebihan. Ia menyebut kebesaran nama, 
keluarganya, dan segala prestasinya di dunia. Ini membuat Dante hanya bisa berguman Listening I bent visage down... (purgatory 11: 188). Di saat yang sama Dante melihat tokoh lain bernama Odirisi.

... and one

(Not he who spake) twisted beneath the weight

that urged him, saw me,

(Purgatory 11: 188)

[...dan salah seorang (bukan dari pembicara sebelumnya) membalikkan beban yang menindih tubuhnya, untuk memandangku,...].

Ciri-ciri kesombongan, seperti wajah yang tidak ingin dipandang lebih rendah dari yang lain ini, telah ditonjolkan sosok Odirisi dalam narasi teks ini.

Dari pemaparan contoh-contoh tersebut di atas, dapat disimpulkan bahwa tokoh-tokoh yang ditemui Dante di alam purgatory bukanlah tokoh-tokoh yang sedang mensucikan semua perbuatan dosanya, tetapi visi yang menggambarkan reaksi terhadap kesalahan dominan yang pernah mereka lakukan semasa hidup. Di alam purgatory tidak digambarkan tokoh-tokoh yang mendapatkan pencucian dosa yang lebih dari dua kali, kecuali Statius. Statius merupakan anomali, yang akan dibahas setelah ini. Tokoh yang ditemui Dante tengah menyelesaikan pencucian dosanya, yaitu Donati Forese di canto 23. Donati telah menyelesaikan pencucian dosa-dosa Rakus, The Gluttonous, dengan tidak diperkenankan memakan buah-buahan yang segar dan meminum air sungai yang jernih di sekitar pos pencucian dosa tersebut. Donati tampak sangat kurus sehingga yang tampak di wajahnya berupa urutan huruf membentuk kata OMO

....Who reads 'omo'

Of man upon his forehead, there the $M$

Had traced mostly plainly (Purgatory 23: 239) 
[Mereka yang memperhatikan kata 'omo' pada wajah orang itu, akan setuju ada lekukan membentuk huruf $M$ dengan sangat jelas (di wajah itu)]

Ukiran $O M O$ di wajah pendosa-pondosa di pos Rakus ini menjelaskan dua hal sekaligus yaitu Pencucian dosa ini menyebabkan tubuh secara fisik mengalami penurunan berat badan yang sangat ekstrim. sepertinya proses pencucian dosa ini diinspirasi dari kisah Erisichthon, sebagaimana Dante membandingkan lulusan pos ini dengan sang tokoh mitologi di Canto yang sama.

\section{...I do not think}

Thus dry and meagre Erisichthon show'd, (Purgatory 23: 239)

[Aku tidak bisa membayangkan seberapa kurus dan tipis Erischthon terlihat]

Erisichthon, diambil dari tokoh mitologi Yunani, adalah seorang raja Thessaly yang melakukan kesalahan dengan memerintahkan rakyatnya menebang pohonpohon di hutan suci Demeter. Peristiwa ini, dalam prosesnya, menyebabkan periperi yang mendiami pepohonan di hutan itu sekarat dan mati. Sebelum peri-peri itu mati, mereka meminta kepada dewa agar Erisichthon mendapat ganjaran atas apa yang diperbuatnya. Dewa-dewa mengabulkan do'a mereka dengan membuat sang raja mengalami kelaparan yang serius dan pada akhirnya ia memakan dirinya sendiri. Yang kedua, OMO sendiri berarti 'manusia' dalam bahasa Latin kuno, yang ditafsirkan bahwa manusia sejati hanya akan terpancar dalam diri orangorang yang mampu menahan menahan rasa tamak dan rakus mereka. (Durling, 1995: 614).

Donati Forese yang diceritakan melaju begitu kencang bersama kawanan arwah-arwah yang lain, setelah menyelesaikan proses penyucian di pos The Gluttonous tempat para jiwa menghapus rasa rakus dengan tidak makan dan 
minum di lingkungan tersebut, ternyata tidak ditemukan di pos pencucian dosa setelahnya, yaitu stasiun The Lustful. Di pos pencucian dosa selanjutnya ini, Dante sama sekali tidak menyinggung atau bahkan bertemu dengan Donati Forese. Ia hanya bertemu dan bernostalgia dengan sahabat-sahabat lamanya yang berprofesi sama, yaitu penyair.

Terkhusus Statius, penyair ini, menurut Dante, mendapatkan hak istimewa dimulai dari melintasi St. Peter Gate, hingga menemani Dante bersama Virgil menuju Earthly Paradise. Dikatakan hak istimewa karena dia sendiri meninggal sebagai seorang Pagan. Statius adalah seorang penyair ternama Italia satu generasi setelah Virgil.

Meskipun ia menemani Dante di empat stasiun purgatory yaitu Prodigal and Avaricious, Gluttonous, Lustful, dan Earthly Paradise, Statius tetap menjaga kekonsistenan sistem tertutup ini dengan melakukan pencucian diri hanya sekali tepatnya di pos pembakaran nafsu. Berdasarkan teks The Divine Comedy, Dante bertemu Statius di pos Avorice and Prodigal, Namun tidak digambarkan dia mengenakan pakaian karung dan dibelenggu sebagaimana yang sistem pencucian dosa di pos tersebut digambarkan, dan tidak kurus kerempeng pada saat berada di pos The Gluttonous, sebagaimana Forese mengalaminya. Statius hanya disucikan di tungku pembakaran nafsu, tempat penyucian jiwa-jiwa kotor membersihkan hawa nafsu mereka selama mereka masih hidup. Dari pemaparan mengenai alam Purgatory di atas terbukti bahwa alam ini tidaklah terbuka sebagaimana dua alam yang lain yang dilalui Dante. 
Setelah memperlihatkan beberapa contoh di atas dapat disimpulkan bahwa ketiga alam di ruang eskatologi Dante merupakan sistem tertutup dimana antara yang satu dengan yang lain tidak bertukar tempat. Berikut dapat dilihat tabel perjalanan Dante dimulai dari Limbo hingga ia berada tepat di bawah singgasana Cahaya Rahmat Tuhan. 


\section{INFERNO}

\begin{tabular}{|c|c|c|c|c|c|c|c|}
\hline Ring & $\begin{array}{l}\text { Sub } \\
- \\
\text { ring }\end{array}$ & Nama Tempat & Dosa/Pahala & Ganjaran & Tokoh & Penuntun & Penjaga \\
\hline \multirow[t]{2}{*}{1} & \multirow[t]{2}{*}{-} & \multirow[t]{2}{*}{ Limbo (earthly hell) } & $\begin{array}{l}\text { Pecundang, tanpa kebaikan, serta } \\
\text { kejahatan }\end{array}$ & $\begin{array}{l}\text { Telanjang, menunggu di } \\
\text { sungai yang busuk, } \\
\text { berlumpur, dikerumuni } \\
\text { belatung dan kutu }\end{array}$ & Pope Calestine V & \multirow[t]{2}{*}{ Virgil } & \multirow[t]{2}{*}{ Charon } \\
\hline & & & $\begin{array}{l}\text { Orang-orang baik yang terlahir } \\
\text { pagan; hidup sebelum kelahiran } \\
\text { Yesus; dan, yang meninggal tanpa } \\
\text { dibaptis }\end{array}$ & $\begin{array}{l}\text { Berkumpul di lembah } \\
\text { berbatu dengan cahaya } \\
\text { matahari yang cukup. }\end{array}$ & $\begin{array}{l}\text { 1. Homer, Horace dan } \\
\text { Ovid } \\
\text { 2. Lucan, Hector, } \\
\text { Aeneas, Caesar, } \\
\text { Latinus, dan Lavinia } \\
\text { 3. Socrates, Plato, dan } \\
\text { Aristoteles, } \\
\text { 4. Camila, Panthesilea } \\
\text { 5. Saladin } \\
\text { 6. Tarquin, Lucretia, } \\
\text { Marcia, dan Cornelia. } \\
\text { 7. Democritus, Diogenes, } \\
\text { Heraclitus, } \\
\text { Empedocles, Thales, } \\
\text { Anaxagoras, Zeno, } \\
\text { 8. Dioscorides, Orpheus, } \\
\text { Linus, Tully, dan } \\
\text { Seneca. }\end{array}$ & & \\
\hline
\end{tabular}




\begin{tabular}{|c|c|c|c|c|c|c|c|}
\hline & & & & & $\begin{array}{l}\text { 9. Euclid, Ibnu Rush, } \\
\text { Galen, Ibnu Sina, dan } \\
\text { Hippocrates. }\end{array}$ & & \\
\hline 2 & - & Lust & $\begin{array}{l}\text { Orang-orang yang semasa hidup } \\
\text { dimabuk cinta, sehingga } \\
\text { membahayakan nyawanya dan } \\
\text { orang lain }\end{array}$ & $\begin{array}{l}\text { Dihantui kegelapan, angin } \\
\text { kencang, dan kesendirian } \\
\text { yang abadi }\end{array}$ & $\begin{array}{l}\text { 1. Semiramis, Dido, } \\
\text { Cleopatra, Helen dan } \\
\text { Paris } \\
\text { 2. Frensisca de Remini }\end{array}$ & Virgil & Minos \\
\hline 3 & - & Gluttony & $\begin{array}{l}\text { Orang-orang yang semasa hidup } \\
\text { sangat rakus }\end{array}$ & $\begin{array}{l}\text { Dihujani lumpur busuk, dan } \\
\text { mereka dibuat lapar } \\
\text { sehingga mereka memakan } \\
\text { lumpur seperti seekor babi }\end{array}$ & Ciaccio & Virgil & Carberus \\
\hline 4 & - & $\begin{array}{l}\text { Avarice and } \\
\text { Prodigal }\end{array}$ & Orang-orang boros dan pelit & $\begin{array}{l}\text { Mendorong batu besar yang } \\
\text { terbuat dari emas, sebagian } \\
\text { (pemboros) berusaha } \\
\text { menukarnya dengan } \\
\text { kemewahan yang lain, dan } \\
\text { sebagian yang lain (Pelit) } \\
\text { berusaha } \\
\text { menyembunyikannya }\end{array}$ & - & Virgil & Plutus \\
\hline 5 & 1 & Anger and Accidia & Pemarah & Mereka dikumpulkan dalam & - & Virgil & Phlegyas \\
\hline
\end{tabular}




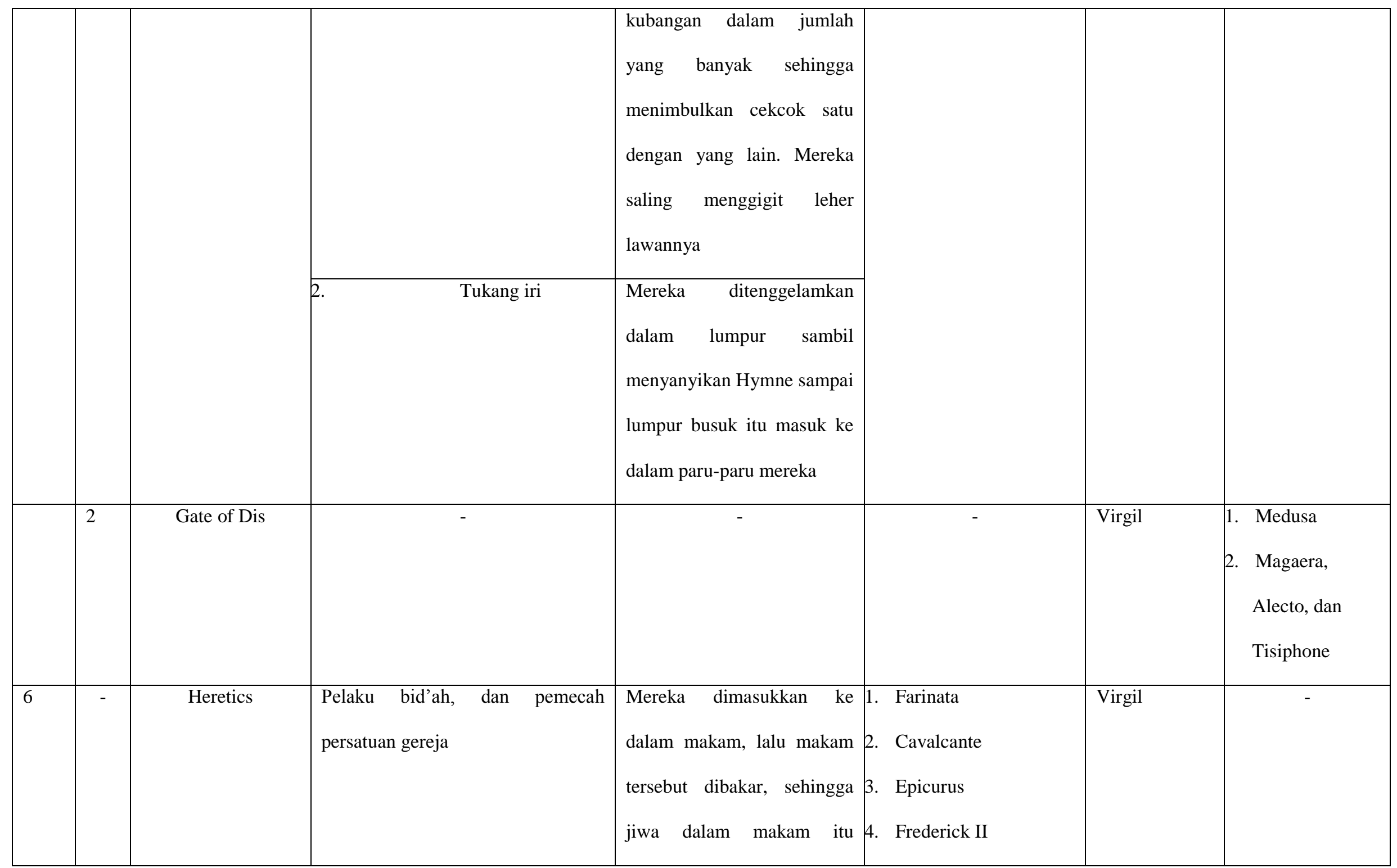




\begin{tabular}{|c|c|c|c|c|c|c|c|}
\hline & & & & bangkit kepanasan. & & & \\
\hline \multirow{2}{*}{\multicolumn{2}{|c|}{7}} & Violence & Pelaku kekerasan dan menyakiti & & & & \\
\hline & & $\begin{array}{c}\text { Violence against } \\
\text { Others }\end{array}$ & Pembunuh, perampok, dan penjarah & $\begin{array}{l}\text { Direndam ke dalam sungai } \\
\text { darah dan nanah yang } \\
\text { mendidih, } \\
\text { Kedalaman rendamannya } \\
\text { diatur berdasarkan jumlah } \\
\text { manusia yang dibunuh. } \\
\text { Semakin dalam semakin } \\
\text { biadab }\end{array}$ & $\begin{array}{l}\text { 1. Theseus } \\
\text { 2. Alexander agung, } \\
\text { Dionysius, Ezolino, } \\
\text { dan Obizzo } \\
\text { 3. Guy de Montfort } \\
\text { 4. Attila, dan Pirus } \\
\text { 5. Rinier Pazzo, dan } \\
\text { Rinier da Cornetto }\end{array}$ & $\begin{array}{ll}\text { 1. } & \text { Virgil } \\
\text { 2. } & \text { Nessus }\end{array}$ & $\begin{array}{ll}\text { 1. } & \text { Minotaur } \\
\text { 2. } & \text { Centaurs } \\
\text { 3. } & \text { Chiron } \\
\text { 4. } & \text { Pholus }\end{array}$ \\
\hline & 3 & Violence against & Para takabur, menantang Tuhan & Mereka $\quad$ dikumpulkan di & - & \begin{tabular}{|l|} 
Virgil \\
\end{tabular} & Capaneus \\
\hline
\end{tabular}




\begin{tabular}{|c|c|c|c|c|c|c|c|}
\hline & & God & & $\begin{array}{l}\text { sebuah padang pasir yang } \\
\text { kering, dan panas akibat } \\
\text { hujan lava. }\end{array}$ & & & \\
\hline & 4 & $\begin{array}{c}\text { Violence against } \\
\text { nature }\end{array}$ & $\begin{array}{l}\text { Jiwa-jiwa kotor yang menolak seni } \\
\text { dan sifat dasar manusia; } \\
\text { homosexual }\end{array}$ & $\begin{array}{l}\text { Mereka dikumpulkan di } \\
\text { suatu tempat lalu dicambuk } \\
\text { oleh makhluk aneh bertubuh } \\
\text { manusia dengan ekor dan } \\
\text { kepala yang lebih mirip } \\
\text { seekor kambing. }\end{array}$ & 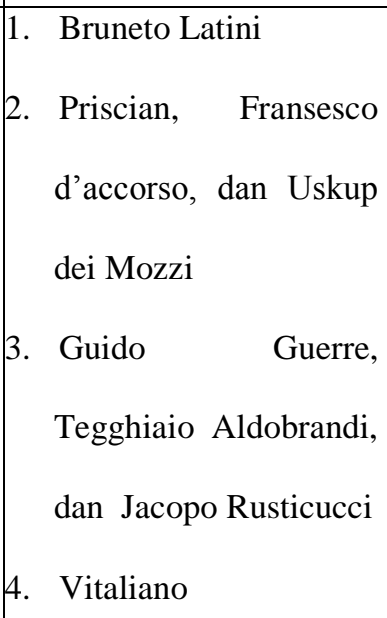 & Virgil & Geryon \\
\hline 8 & & Malebogne & \multicolumn{4}{|c|}{ Pelaku penipuan tingkat rendah } & \\
\hline & 1 & Pimp and seducers & Para germo dan pemerkosa & $\begin{array}{l}\text { Tubuh mereka dihujani } \\
\text { rintik hujan lava, sehingga } \\
\text { kulit mereka terbakar. }\end{array}$ & $\begin{array}{l}\text { 1. Venedico } \\
\text { 2. Jason of the argonauts }\end{array}$ & Virgil & \\
\hline & 2 & Flatters & Para penjilat & 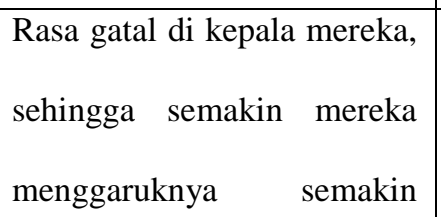 & Alessio Intermenici & Virgil & - \\
\hline
\end{tabular}




\begin{tabular}{|c|c|c|c|c|c|c|}
\hline & & & $\begin{array}{l}\text { mengelupas pula kulit } \\
\text { kepala mereka }\end{array}$ & & & \\
\hline 3 & Simoniac & $\begin{array}{l}\text { Tukang sogok, penerima suap, dan } \\
\text { pelaku nepotisme }\end{array}$ & $\begin{array}{l}\text { Tubuh mereka tertancap } \\
\text { dalam tanah dengan posisi } \\
\text { terbalik, sehingga yang } \\
\text { tampak hanya kaki yang } \\
\text { bergerak minta tolong. }\end{array}$ & $\begin{array}{ll}\text { 1. } & \text { Paus Nicholas II } \\
\text { 2. } & \text { Paus Boniface VIII }\end{array}$ & Virgil & - \\
\hline 4 & Soothsayers & Para astrolog, peramal dan penyihir & $\begin{array}{l}\text { Kepala mereka diplintir } \\
\text { hingga wajahnya menghadap } \\
\text { kebelakang. Memberi kesan } \\
\text { bahwa mereka tidak bisa } \\
\text { membedakan mana berjalan } \\
\text { mundur atau maju. }\end{array}$ & $\begin{array}{l}\text { 1. Tiresias, Amphiarus, } \\
\text { Aruns, dan Manto. } \\
\text { 2. Calehas, Michael } \\
\text { Scot, GuidoBonati } \\
\text { Asdante }\end{array}$ & Virgil & - \\
\hline 5 & Barrator & Pemfitnah, dan pengadu domba & $\begin{array}{lrl}\text { Seperti } & \text { permainan } & \text { drama, } \\
\text { mereka } & \text { terdesak } & \text { untuk } \\
\text { mengamankan diri } & \text { mereka } \\
\text { dengan mengadu } & \text { domba } \\
\text { sesama iblis penjaga. } & \\
\text { Dengan begitu penjaga- }\end{array}$ & $\begin{array}{l}\text { 1. } \text { Fra Gomita } \\
\text { 2. Dol Michele Zenche }\end{array}$ & $\begin{array}{l}\text { Virgil dan } 10 \\
\text { anak buah } \\
\text { Malacoda }\end{array}$ & $\begin{array}{l}\text { 1. Malacoda } \\
\text { 2. Scarmiglione } \\
\text { 3. Anak buah } \\
\text { Malacoda: } \\
\text { Ciriatto, } \\
\text { Libicocco, }\end{array}$ \\
\hline
\end{tabular}




\begin{tabular}{|c|c|c|c|c|c|c|}
\hline & & & $\begin{array}{l}\text { penjaga itu bersiteru satu } \\
\text { sama lain. Namun, itu tidak } \\
\text { berlangsung lama. mereka } \\
\text { akan menyaadari mereka } \\
\text { diadu domba oleh salah satu } \\
\text { pendosa. Si pendosa pun jadi } \\
\text { bulan-bulanan iblis penjaga }\end{array}$ & & & $\begin{array}{l}\text { Draghignazze, } \\
\text { Farfalecco, } \\
\text { Alinchino, } \\
\text { Barbaniccia, } \\
\text { Grafficane, } \\
\text { Pubicante, } \\
\text { Cagnazzo, dan } \\
\text { Calacabrina }\end{array}$ \\
\hline 6 & Hypocrites & Orang-orang munafik & $\begin{array}{l}\text { Mereka mengenakan zirah } \\
\text { perang yang terbuat dari } \\
\text { timbal yang berat, berjalan } \\
\text { jauh dan curam }\end{array}$ & $\begin{array}{l}\text { 1. Fra Catalano } \\
\text { 2. Kayafas }\end{array}$ & Virgil & - \\
\hline 7 & Thieves & Pencuri & $\begin{array}{l}\text { Pendosa dililiti ular piton } \\
\text { yang besar yang tidak lain } \\
\text { wujud dari pendosa yang } \\
\text { lain. Setelah tulang pendosa } \\
\text { remuk, ular tersebut kembali } \\
\text { ke wujud manusia, lalu } \\
\text { manusia yang telah remuk }\end{array}$ & $\begin{array}{l}\text { 1. Vanni Fucci } \\
\text { 2. Agnello } \\
\text { 3. Puccio Sciancato, } \\
\text { Gaville }\end{array}$ & Virgil & $\begin{array}{ll}\text { 1. } & \text { Ciafna } \\
\text { 2. } & \text { Centaur }\end{array}$ \\
\hline
\end{tabular}




\begin{tabular}{|c|c|c|c|c|c|c|}
\hline & & & $\begin{array}{l}\text { itu berubah wujud menjadi } \\
\text { ular, untuk selanjutnya } \\
\text { melakukan serangan balik. } \\
\text { Begitu seterusnya. }\end{array}$ & & & \\
\hline 8 & Conselor of Fraud & $\begin{array}{l}\text { Pemimpin-pemimpin yang } \\
\text { menyesatkan, membahayakan, dan } \\
\text { menipu rakyatnya }\end{array}$ & $\begin{array}{l}\text { Dari kelenjar keringat } \\
\text { mereka keluar api, sehingga } \\
\text { tubuh mereka terbakar }\end{array}$ & $\begin{array}{l}\text { 1. } \text { Ullyses, Diomedes, } \\
\text { 2. Guido Da Mantefelto }\end{array}$ & Virgil & - \\
\hline 9 & Schism Sower & $\begin{array}{l}\text { Pemimpin yang memecah agama, } \\
\text { keyakinan, dan persatuan, dan para } \\
\text { pelaku skandal }\end{array}$ & $\begin{array}{l}\text { Tubuh mereka disabet } \\
\text { dengan pedang. Sehingga } \\
\text { ada yang kehilangan anggota } \\
\text { tubuh, ususnya terburai, } \\
\text { wajahnya terbelah, bahkan } \\
\text { ada yang kehilangan kepala. }\end{array}$ & $\begin{array}{ll}\text { 1. } & \text { Muhammed } \\
\text { 2. } & \text { Ali (sepupu } \\
& \text { Muhammad) } \\
\text { 3. } & \text { Perda Medicina } \\
\text { 4. } & \text { Curio, Mosca } \\
\text { 5. } & \text { Bertrand De Born } \\
\text { 6. } & \text { Gery Del Bello }\end{array}$ & Virgil & - \\
\hline 10 & Counterfeiters & $\begin{array}{l}\text { Pelaku Penyalahguna kepercayaan, } \\
\text { dan penipu. }\end{array}$ & $\begin{array}{l}\text { Terinfeksi penyakit typhus } \\
\text { (penyakit paling parah pada } \\
\text { saat itu) sehingga mereka } \\
\text { merintih kesakitan }\end{array}$ & 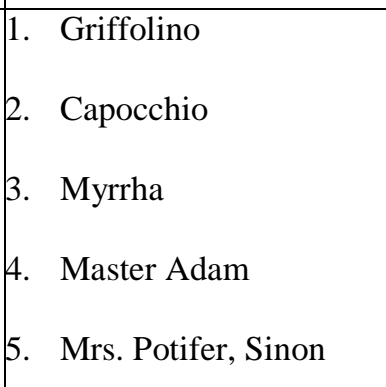 & Virgil & \\
\hline
\end{tabular}




\begin{tabular}{|c|c|c|c|c|c|c|c|}
\hline & 11 & Giant City & $\begin{array}{l}\text { Pendosa yang berupaya keras } \\
\text { mengalahkan Tuhan dengan } \\
\text { menguasai dunia }\end{array}$ & $\begin{array}{l}\text { Mereka tumbuh besar seperti } \\
\text { raksasa di ruang yang } \\
\text { sempit. Mereka dirantai } \\
\text { seperti hewan ternak }\end{array}$ & $\begin{array}{l}\text { Nimrod, Ephialtes, dan } \\
\text { Briareus }\end{array}$ & Virgil & Antaeus \\
\hline 9 & & Cocytus & \multicolumn{4}{|c|}{ Pelaku penipuan level berat; para penghianat, } & \\
\hline & 1 & Caina & $\begin{array}{l}\text { Penghianatan terhadap keluarga } \\
\text { sendiri }\end{array}$ & $\begin{array}{l}\text { Pendosa dipendam dalam } \\
\text { sungai beku hingga yang } \\
\text { tampak hanya batok kepala } \\
\text { dan matanya saja, } \\
\text { digambarkan mirip katak } \\
\text { yang bersembunyi di rawa }\end{array}$ & $\begin{array}{l}\text { 1. Bizenso } \\
\text { 2. Sassol Mascheroni } \\
\text { 4. Camiscion de' Pazzi } \\
\text { dan Becherria } \\
\text { 5. Gianni De' Soldanier, } \\
\text { Ganelon, Tebaldello }\end{array}$ & Virgil & \\
\hline & 2 & Antenora & Penghianatan terhadap negara & $\begin{array}{l}\text { Mereka dipendam dalam } \\
\text { sungai es yang tebal dengan } \\
\text { gigi yang bergemeretak } \\
\text { karena kedinginan sambil } \\
\text { menggigit batok kepala } \\
\text { pendosa yang lain }\end{array}$ & Count Ugolino & Virgil & \\
\hline & 3 & Ptolemea & Penghianatan terhadap tamu & Mereka berbaring di atas & 1. Fra Alberigo & Virgil & \\
\hline
\end{tabular}




\begin{tabular}{|c|c|c|c|c|c|c|c|}
\hline & & & & $\begin{array}{l}\text { sungai es dalam keadaan } \\
\text { telanjang. Air matanya } \\
\text { mengalir hingga menjadi es } \\
\text { dan menusuk mata mereka }\end{array}$ & 2. Branca Doria & & \\
\hline & 4 & Judecca & $\begin{array}{l}\text { Pengkhianatan terhadap pemimpin, } \\
\text { raja, dan pemimpin agama }\end{array}$ & $\begin{array}{l}\text { 1. } \\
\text { membatu, } \\
\text { 2. } \\
\text { dengadi es yang padat. } \\
\text { denan lahap oleh Lucifer. }\end{array}$ & $\begin{array}{ll}\text { 1. } & \text { Judas } \\
\text { 2. } & \text { Brutus } \\
\text { 3. } & \text { Cassius }\end{array}$ & Virgil & Lucifer \\
\hline \multicolumn{8}{|c|}{ PURGATORY } \\
\hline 1 & & The Late Repentant & \multicolumn{4}{|c|}{ Perjalanan panjang menuju gunung penyucian } & \\
\hline & 1 & Excommunicate & $\begin{array}{l}\text { Jiwa-jiwa yang terkucilkan, baru } \\
\text { saja meninggal }\end{array}$ & $\begin{array}{l}\text { Menjelajahi samudera yang } \\
\text { teramat luas }\end{array}$ & $\begin{array}{ll}\text { 1. } & \text { Casella } \\
\text { 2. } & \text { Manfred }\end{array}$ & Virgil & $\begin{array}{ll}\text { 1. } & \text { Angel } \\
\text { 2. } & \text { Cato }\end{array}$ \\
\hline & 2 & The indolent & Jiwa-jiwa putus asa & $\begin{array}{l}\text { Mereka berbaring, malas- } \\
\text { malasan menunggu do'a dari } \\
\text { manusia (keluarga) yang } \\
\text { masih hidup agar bisa } \\
\text { melanjutkan perjalanan }\end{array}$ & Belacqua & Virgil & - \\
\hline & 3 & The unabsolved & $\begin{array}{l}\text { Jiwa-jiwa yang menghadapi } \\
\text { kematian yang menyiksa, namun } \\
\text { menyempatkan diri bertobat } \\
\text { sebelum detik-detik kematian tiba }\end{array}$ & $\begin{array}{l}\text { Jiwa-jiwa tersebut masih } \\
\text { menyimpan dendam di } \\
\text { dunia, sehingga mereka } \\
\text { tidak diperkenankan } \\
\text { melanjutkan perjalanan }\end{array}$ & $\begin{array}{ll}\text { 1. } & \text { Jacopo Del Cassero } \\
\text { 2. } & \text { Beloconte Da } \\
& \text { Montefeltro } \\
\text { 3. } & \text { La Pia } \\
\text { 4. } & \text { Benincasa, Federigo, } \\
& \text { Prince Orso, dan Pierre }\end{array}$ & Virgil & - \\
\hline
\end{tabular}




\begin{tabular}{|c|c|c|c|c|c|c|c|}
\hline & & & & & $\begin{array}{ll}\text { Dela Brosse } \\
\text { 5. } & \text { Sardello De Mantoa }\end{array}$ & & \\
\hline & 4 & $\begin{array}{c}\text { The Negligent } \\
\text { Rulers }\end{array}$ & Penegak hukum yang lalai & 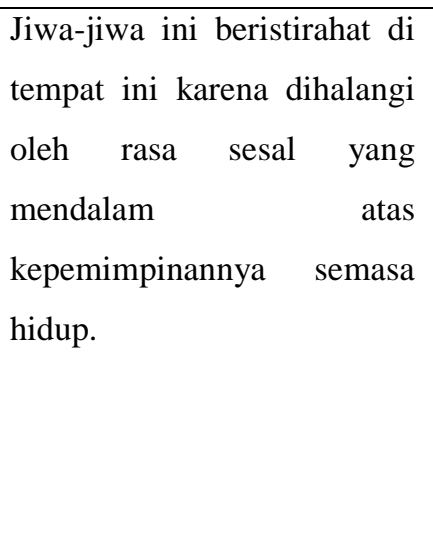 & 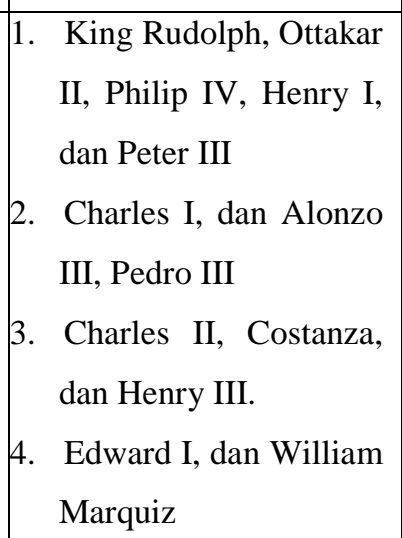 & 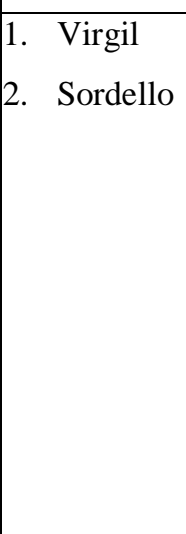 & - \\
\hline 2 & & Ante-Purgatory & \begin{tabular}{lrr} 
Jiwa-jiwa & \multicolumn{2}{r}{ berkumpul } \\
mempersiapkan & diri $\quad$ untuk \\
disucikan & & \\
\end{tabular} & $\begin{array}{l}\text { Kening jiwa-jiwa ini } \\
\text { ditandai dengan irisan } \\
\text { pedang, membentuk huruf } \mathrm{P} \\
\text { sebanyak } 7 \text { buah. Jumlah } \\
\text { dosa mematikan yang akan } \\
\text { disucikan }\end{array}$ & $\begin{array}{ll}\text { 1. } & \text { Hakim Nino } \\
\text { 2. } & \text { Currado II }\end{array}$ & 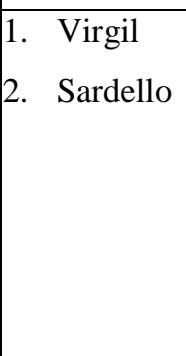 & $\begin{array}{ll}\text { 1. } & \text { Malaikat pirang } \\
\text { 2. } & \text { Ular }\end{array}$ \\
\hline 3 & - & The Praud & Penyucian sifat sombong & $\begin{array}{l}\text { Jiwa-jiwa yang disucikan } \\
\text { memikul batu besar di } \\
\text { punggung mereka sambil } \\
\text { menyusuri tanjakan menuju } \\
\text { pos selanjutnya }\end{array}$ & Omberto, Odirisi & Virgil & Michael \\
\hline 4 & - & The Envious & Penyucian sifat-sifat iri dan dengki & $\begin{array}{l}\text { Jiwa-jiwa yang disucikan } \\
\text { dibutakan dengan cara } \\
\text { kelopak mata mereka dijahit. } \\
\text { Mereka berkumpul di suatu }\end{array}$ & $\begin{array}{ll}\text { 1. } & \text { Sapia } \\
\text { 2. } & \text { Guido Del Ducca, dan } \\
\text { Rinieri Da Calbollii } \\
\text { 3. Aglauros }\end{array}$ & Virgil & - \\
\hline
\end{tabular}




\begin{tabular}{|c|c|c|c|c|c|c|c|}
\hline & & & & $\begin{array}{l}\text { tempat, menunggu hingga } \\
\text { sifat-sifat iri itu benar-benar } \\
\text { bersih dari diri mereka. }\end{array}$ & & & \\
\hline 5 & - & The wrathful & $\begin{array}{l}\text { Penghapusan sifat tempramental, } \\
\text { dan ketidak sabaran }\end{array}$ & 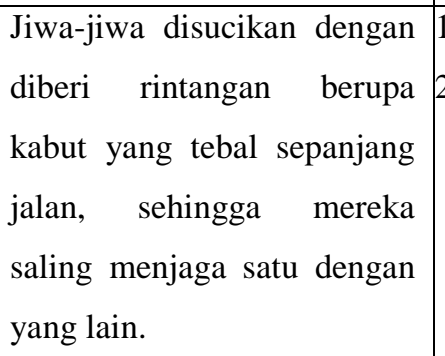 & $\begin{array}{ll}\text { 1. } & \text { Lombard } \\
\text { 2. } & \text { Marco }\end{array}$ & Virgil & - \\
\hline 6 & - & The Slothful & $\begin{array}{l}\text { Penyucian sifat malas, dan iman } \\
\text { yang melemah }\end{array}$ & $\begin{array}{l}\text { Menyanyikan mars hingga } \\
\text { menetap keyakinannya }\end{array}$ & - & Virgil & - \\
\hline 7 & - & $\begin{array}{l}\text { The Avaricius and } \\
\text { Prodigal }\end{array}$ & $\begin{array}{l}\text { Penyucian sifat serakah, kikir, } \\
\text { boros, dan pamer }\end{array}$ & $\begin{array}{l}\text { Mereka dirantai sambil } \\
\text { mengenakan pakaian dari } \\
\text { karung yang gatal untuk } \\
\text { merasakan kesederhanaan } \\
\text { dan kemalangan dalam } \\
\text { waktu yang sangat lama. }\end{array}$ & $\begin{array}{ll}\text { 1. } & \text { Hugh Capet } \\
\text { 2. } & \text { Statius }\end{array}$ & Virgil & - \\
\hline 8 & - & The Gluttonous & Penghapusan sifat-sifat rakus & $\begin{array}{l}\text { Mereka dikelilingi air yang } \\
\text { sejuk, dan pohon-pohon } \\
\text { berbuah segar yang } \\
\text { bisikannya menghasut untuk } \\
\text { memakan buah itu. Namun, } \\
\text { mereka dilarang untuk } \\
\text { memakan atau meminum } \\
\text { apapun yang ada di } \text { taman } \\
\text { tersebut }\end{array}$ & $\begin{array}{ll}\text { 1. } & \text { Donati Forese } \\
\text { 2. } & \text { Bonaguinta } \\
\text { 3. } & \text { Da Lucca } \\
& \\
\end{array}$ & $\begin{array}{ll}\text { 1. } & \text { Virgil } \\
\text { 2. } & \text { Statuis }\end{array}$ & \\
\hline
\end{tabular}




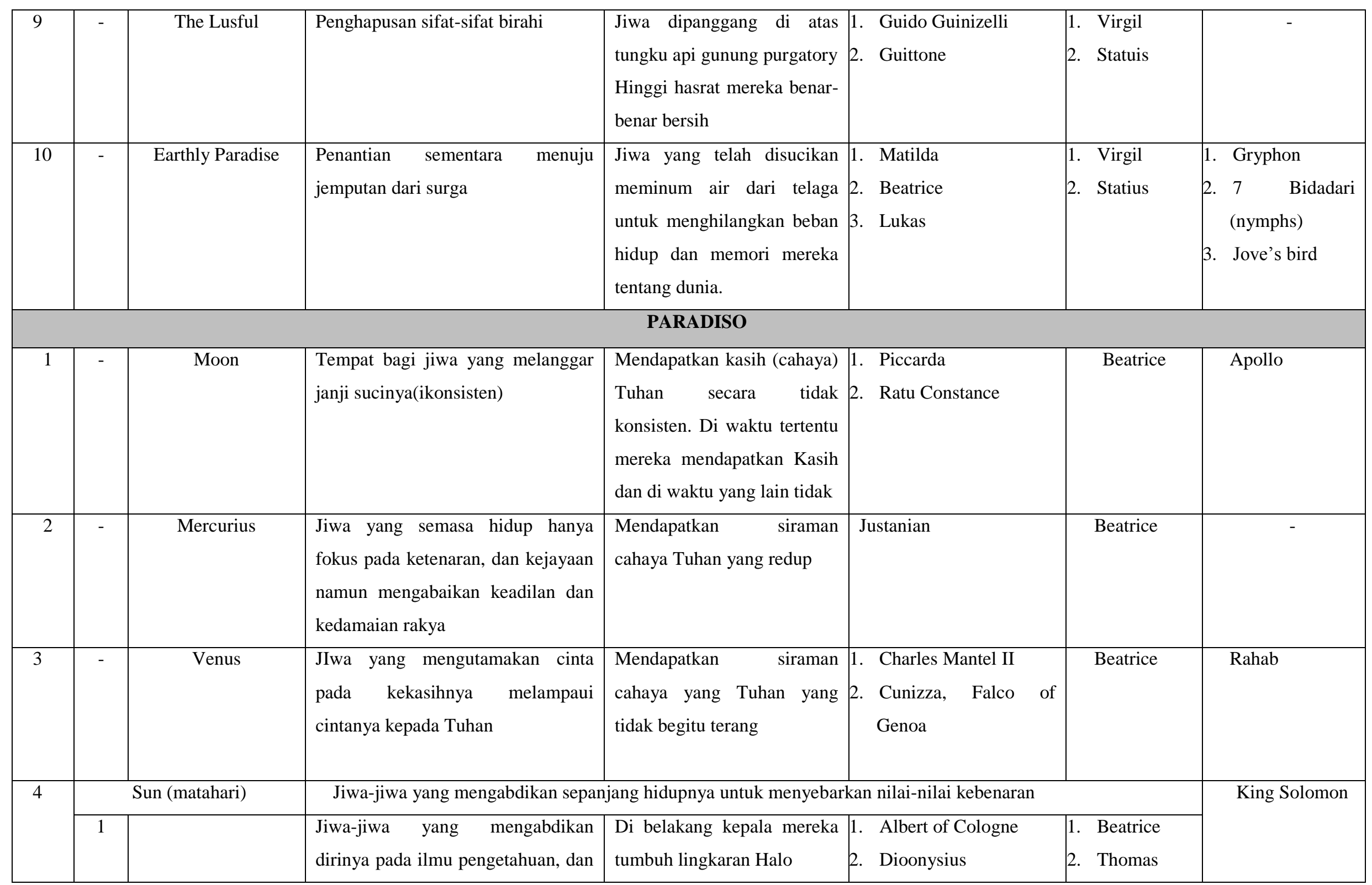




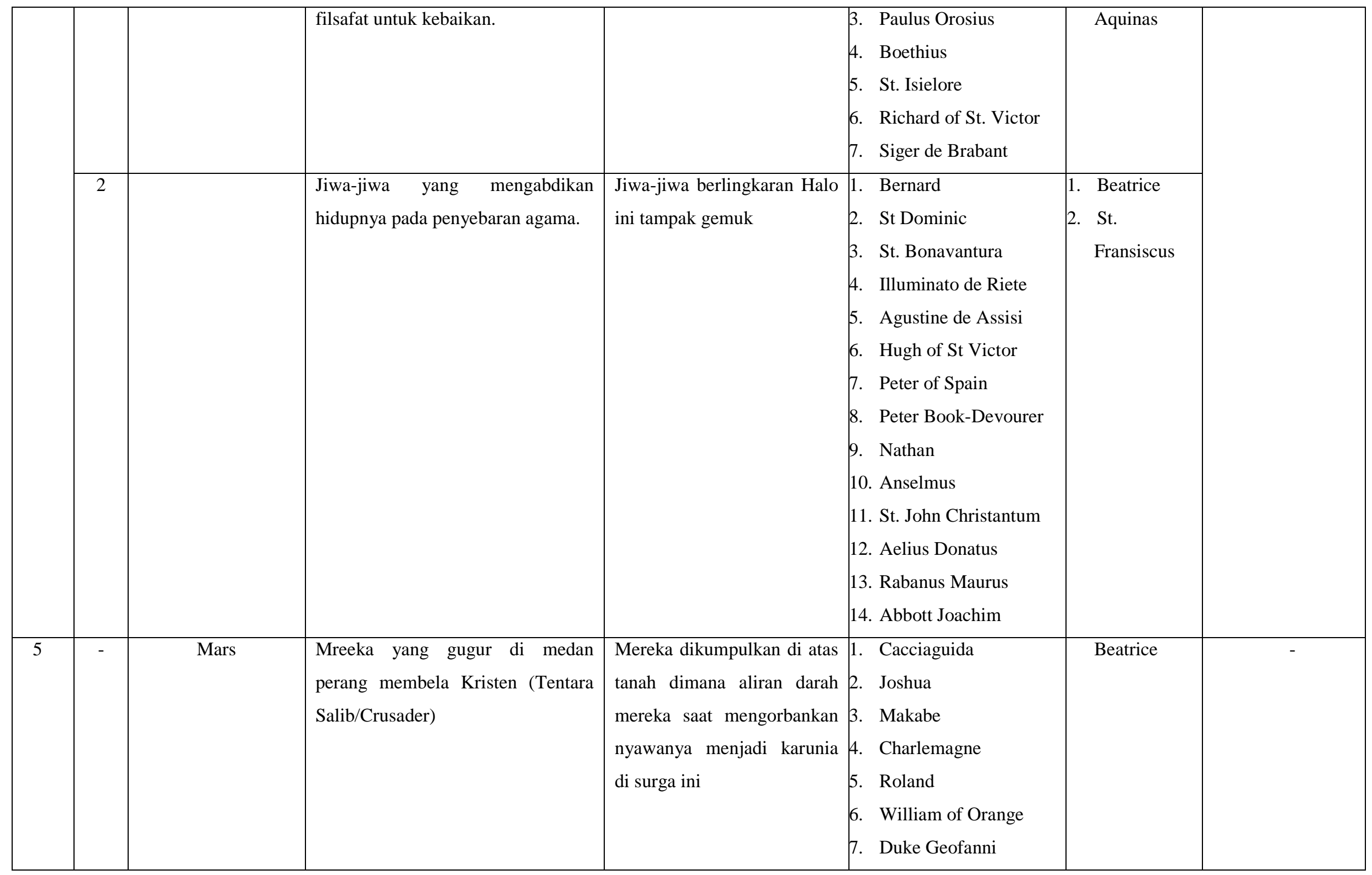




\begin{tabular}{|c|c|c|c|c|c|c|c|}
\hline & & & & & 8. Robert Guiscard & & \\
\hline 6 & - & Jupiter & $\begin{array}{l}\text { Para hakim, dan pemimpin yang } \\
\text { adil }\end{array}$ & $\begin{array}{l}\text { Mereka menyanyikan Mars } \\
\text { dengan lengkingan yang } \\
\text { sangat tinggi, membentuk } \\
\text { formasi elang (lambang } \\
\text { kejayaan bangsa Romawi). }\end{array}$ & $\begin{array}{ll}\text { 1. } & \text { Trajan of Rome } \\
\text { 2. } & \text { Hezekiyah } \\
\text { 3. } & \text { Constantine } \\
\text { 4. } & \text { William of Hauteville } \\
\text { 5. } & \text { Ripheus of Trojan }\end{array}$ & Beatrice & King David \\
\hline 7 & - & Saturnus & 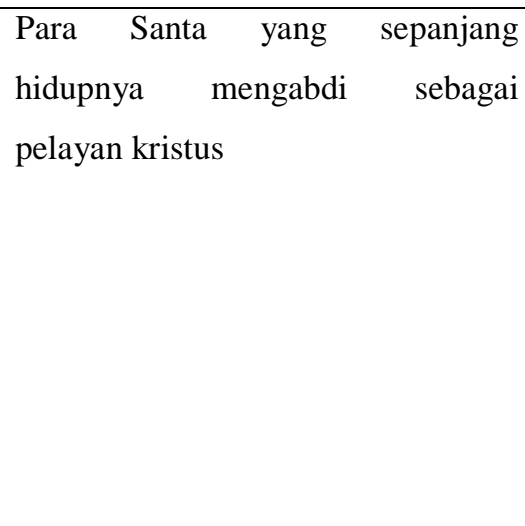 & $\begin{array}{l}\text { Mereka mendapatkan } \\
\text { keagungan yang sangat } \\
\text { tinggi. Mulai dari surga ini } \\
\text { mereka tidak lagi bernyanyi } \\
\text { di hadapan Dante (wujud } \\
\text { manusia) karena telinga } \\
\text { manusia akan pecah } \\
\text { mendengar senandung } \\
\text { mereka. }\end{array}$ & $\begin{array}{ll}\text { 1. } & \text { St. Peter of Damian } \\
\text { 2. } & \text { St. Benedict } \\
\text { 3. } & \text { Macarius of Egypt } \\
\text { 4. } & \text { Romuladus }\end{array}$ & Beatrice & - \\
\hline
\end{tabular}




\begin{tabular}{|c|c|c|c|c|c|c|c|}
\hline 9 & - & Premium Mobile & $\begin{array}{l}\text { Pusat segala gerak materi; } \\
\text { penggerak waktu; cermin dari } \\
\text { segala surga }\end{array}$ & \begin{tabular}{|l|l|} 
Gradasi Refleksi Surga \\
Angelic Tampak Dari Sini, \\
Masing-Masing Memiliki \\
Nama: \\
1. \\
2. & Seraphim Cermin Moon \\
3. & Thrones Cermin Cermin Venus \\
4. & Dominios Cermin Sun \\
5. & Virtues Cermin Mars \\
6. & Powers Cermin Jupiter \\
7. & Principalities cermin \\
8. Saturnus & Arch-angel cermin Fixed \\
9. Stars & Angel cermin Empyrean
\end{tabular} & - & Beatrice & Angels \\
\hline
\end{tabular}




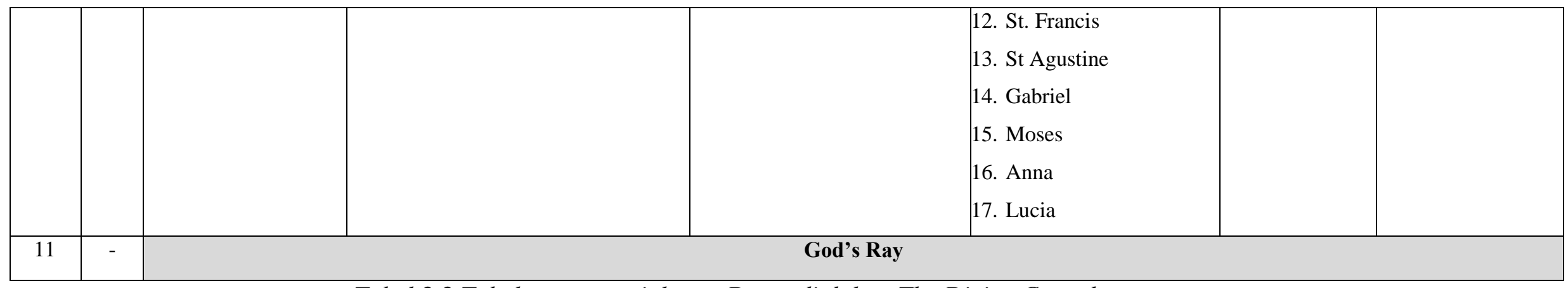

Tabel 2.2 Tabel urutan perjalanan Dante di dalam The Divine Comedy 
Setelah memperhatikan tabel di atas, dapat disusun sebuah urutan hirarki dari tokoh-tokoh yang mendapatkan reaksi terhadap dosa atau amalan yang mereka dapatkan atau akui di dalam commedia semasa mereka hidup. Urutan di atas belum menunjukkan hirarki yang jelas, mengingat perjalanan menuju neraka mengalami gerak hirarki yang menurun (dari mulia ke hina). Hal ini disebabkan neraka termulia, digambarkan, berada paling dekat dengan permukaan bumi, paling dekat dengan gerbang akhirat sehingga untuk melanjutkan perjalanan, Dante menyusuri bagian terluar terlebih dahulu untuk tiba di neraka terdalam.

Ini berbanding terbalik dengan perjalanan yang dilalui Dante di alam Purgatory dan alam Paradise. Penyair harus menyisir ruang yang terhina di alam purgatory maupun Paradise dahulu untuk tiba di tempat yng paling mulia. Dapat diartikan bahwa perjalanan Purgatory dan Paradise adalah gerak hirarki menanjak (hina ke mulia). Perbedaan ini, dapat disimpulkan, muncul akibat inti yang akan didatangi Dante secara nilai berbeda. Inti dari neraka adalah yang terhina/terkutuk, sedangkan inti dari Purgatory dan Paradiso adalah kemuliaan.

Berikut ini adalah tabel eskatologi Dante setelah disusun ulang berdasarkan hirarki dari yang paling mulia hingga yang paling hina. 


\begin{tabular}{|c|c|c|c|c|c|c|c|}
\hline \multicolumn{8}{|c|}{ God's Ray } \\
\hline \multicolumn{8}{|c|}{ PARADISO } \\
\hline Ring & $\begin{array}{l}\text { Sub } \\
- \\
\text { ring }\end{array}$ & Nama Tempat & Dosa/Pahala & Ganjaran & Tokoh & Penuntun & Penjaga \\
\hline 1 & - & The Empyrean & $\begin{array}{l}\text { 1. Surga para tokoh di dalam } \\
\text { perjanjian lama dan perjanjian } \\
\text { baru. } \\
\text { 2. Malaikat-malaikat suciAnak- } \\
\text { anak tidak bersalah sebelum } \\
\text { kedatangan Kristus. } \\
\text { 3. Jiwa-jiwa yang melakukan } \\
\text { pengorbanan diri untuk ajaran } \\
\text { Kristus }\end{array}$ & $\begin{array}{l}\text { Jiwa-jiwa berada di tempat } \\
\text { termulia dngan tidak } \\
\text { berjarak dengan cahaya } \\
\text { kemuliaan Tuhan }\end{array}$ & 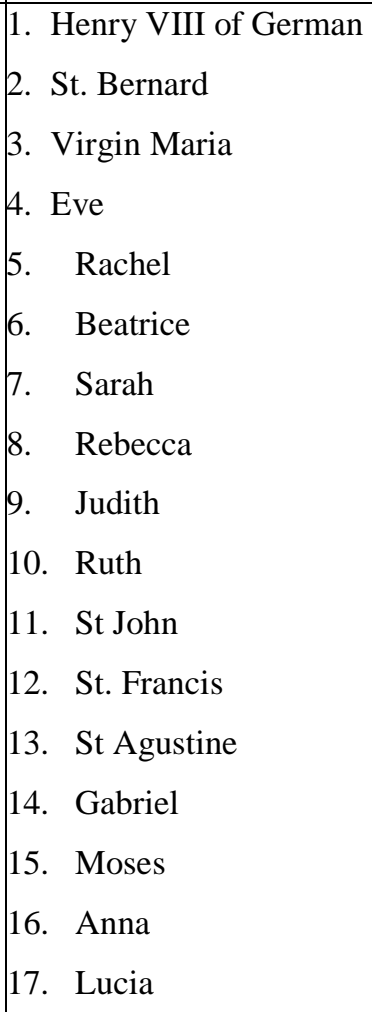 & - & Jesus \\
\hline
\end{tabular}




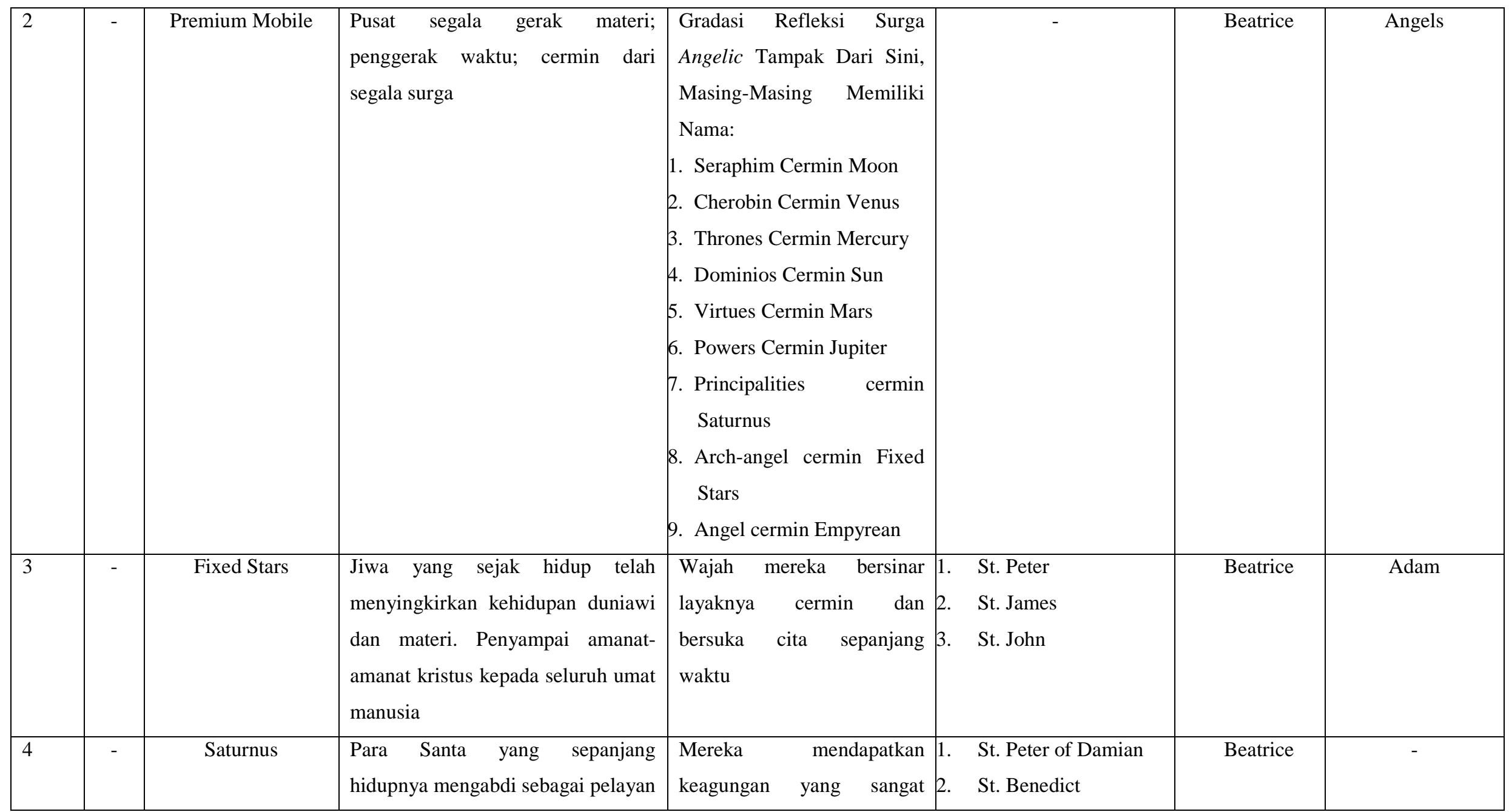




\begin{tabular}{|c|c|c|c|c|c|c|c|}
\hline & & & kristus & 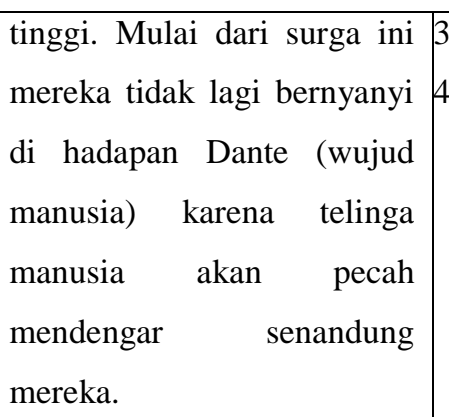 & $\begin{array}{l}\text { 3. } \text { Macarius of Egypt } \\
\text { 4. } \text { Romuladus }\end{array}$ & & \\
\hline 6 & - & Mars & $\begin{array}{l}\text { Mreeka yang gugur di medan } \\
\text { perang membela Kristen (Tentara } \\
\text { Salib/Crusader) }\end{array}$ & $\begin{array}{l}\text { Mereka dikumpulkan di atas } \\
\text { tanah dimana aliran darah } \\
\text { mereka saat mengorbankan } \\
\text { nyawanya menjadi karunia } \\
\text { di surga ini }\end{array}$ & $\begin{array}{ll}\text { 1. } & \text { Cacciaguida } \\
\text { 2. } & \text { Joshua } \\
\text { 3. } & \text { Makabe } \\
\text { 4. } & \text { Charlemagne } \\
\text { 5. } & \text { Roland } \\
\text { 6. } & \text { William of Orange } \\
\text { 7. } & \text { Duke Geofanni } \\
\text { 8. } & \text { Robert Guiscard }\end{array}$ & Beatrice & - \\
\hline 7 & & & Sun (matahari) & \multicolumn{3}{|c|}{$\begin{array}{l}\text { Jiwa-jiwa yang mengabdikan sepanjang hidupnya untuk menyebarkan } \\
\text { nilai-nilai kebenaran }\end{array}$} & King Solomon \\
\hline
\end{tabular}




\begin{tabular}{|c|c|c|c|c|c|c|c|c|}
\hline & 1 & & $\begin{array}{l}\text { Jiwa-jiwa yang mengabdikan } \\
\text { hidupnya pada penyebaran agama. }\end{array}$ & $\begin{array}{l}\text { Jiwa-jiwa berlingkaran Halo } \\
\text { ini tampak gemuk }\end{array}$ & $\begin{array}{l}1 . \\
2 . \\
3 . \\
3 . \\
4 . \\
5 . \\
6 . \\
7 . \\
8 . \\
9 . \\
11 \\
1 . \\
12 \\
1 . \\
1 .\end{array}$ & $\begin{array}{l}\text { Bernard } \\
\text { St Dominic } \\
\text { St. Bonavantura } \\
\text { Illuminato de Riete } \\
\text { Agustine de Assisi } \\
\text { Hugh of St Victor } \\
\text { Peter of Spain } \\
\text { Peter Book-Devourer } \\
\text { Natha } \\
\text { Anselmus } \\
\text { St. John Christantum } \\
\text { Aelius Donatus } \\
\text { Rabanus Maurus } \\
\text { Abbott Joachim }\end{array}$ & $\begin{array}{l}\text { 1. Beatrice } \\
\text { 2. St. } \\
\text { Fransiscus }\end{array}$ & \\
\hline & 2 & & $\begin{array}{l}\text { Jiwa-jiwa yang mengabdikan } \\
\text { dirinya pada ilmu pengetahuan, dan } \\
\text { filsafat untuk kebaikan. }\end{array}$ & $\begin{array}{l}\text { Di belakang kepala mereka } \\
\text { tumbuh lingkaran Halo }\end{array}$ & & $\begin{array}{l}\text { Albert of Cologne } \\
\text { Dioonysius } \\
\text { Paulus Orosius } \\
\text { Boethius } \\
\text { St. Isielore } \\
\text { Richard of St. Victor } \\
\text { Siger de Brabant }\end{array}$ & $\begin{array}{l}\text { 1. Beatrice } \\
\text { 2. Thomas } \\
\text { Aquinas }\end{array}$ & \\
\hline 8 & - & Venus & JIwa yang mengutamakan cinta & Mendapatkan siraman & & Charles Mantel II & Beatrice & Rahab \\
\hline
\end{tabular}




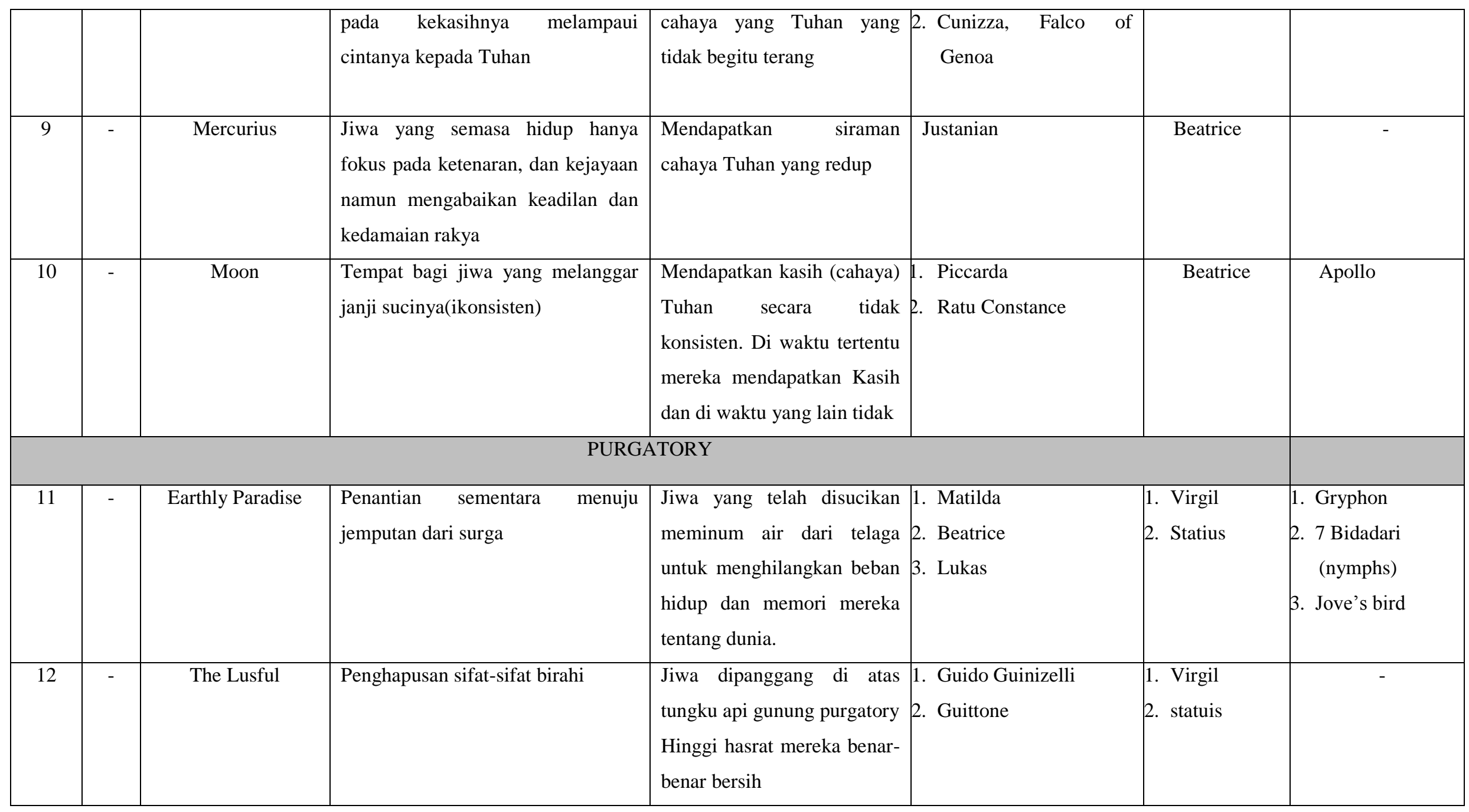




\begin{tabular}{|c|c|c|c|c|c|c|c|}
\hline 13 & - & The Gluttonous & Penghapusan sifat-sifat rakus & $\begin{array}{l}\text { Mereka dikelilingi air yang } \\
\text { sejuk, dan pohon-pohon } \\
\text { berbuah segar yang } \\
\text { bisikannya menghasut untuk } \\
\text { memakan buah itu. Namun, } \\
\text { mereka dilarang untuk } \\
\text { memakan atau meminum } \\
\text { apapun yang ada di taman } \\
\text { tersebut }\end{array}$ & $\begin{array}{ll}\text { 1. } & \text { Donati Forese } \\
\text { 2. } & \text { Bonaguinta } \\
\text { 3. } & \text { Da Lucca }\end{array}$ & $\begin{array}{l}\text { 1. } \text { Virgil } \\
\text { 2. Statuis }\end{array}$ & \\
\hline 14 & - & $\begin{array}{l}\text { The Avaricius and } \\
\text { Prodigal }\end{array}$ & $\begin{array}{l}\text { Penyucian sifat serakah, kikir, } \\
\text { boros, dan pamer }\end{array}$ & $\begin{array}{l}\text { Mereka dirantai sambil } \\
\text { mengenakan pakaian dari } \\
\text { karung yang gatal untuk } \\
\text { merasakan kesederhanaan } \\
\text { dan kemalangan dalam } \\
\text { waktu yang sangat lama. }\end{array}$ & $\begin{array}{l}\text { 1. Hugh Capet } \\
\text { 2. Statius }\end{array}$ & Virgil & - \\
\hline 15 & - & The Slothful & $\begin{array}{l}\text { Penyucian sifat malas, dan iman } \\
\text { yang melemah }\end{array}$ & $\begin{array}{l}\text { Menyanyikan mars hingga } \\
\text { menetap keyakinannya }\end{array}$ & - & Virgil & - \\
\hline 16 & - & The wrathful & $\begin{array}{l}\text { Penghapusan sifat tempramental, } \\
\text { dan ketidak sabaran }\end{array}$ & $\begin{array}{l}\text { Jiwa-jiwa disucikan dengan } \\
\text { diberi rintangan berupa } \\
\text { kabut yang tebal sepanjang } \\
\text { jalan, sehingga mereka } \\
\text { saling menjaga satu dengan }\end{array}$ & $\begin{array}{l}\text { 1. Lombard } \\
\text { 2. Marco }\end{array}$ & Virgil & - \\
\hline
\end{tabular}




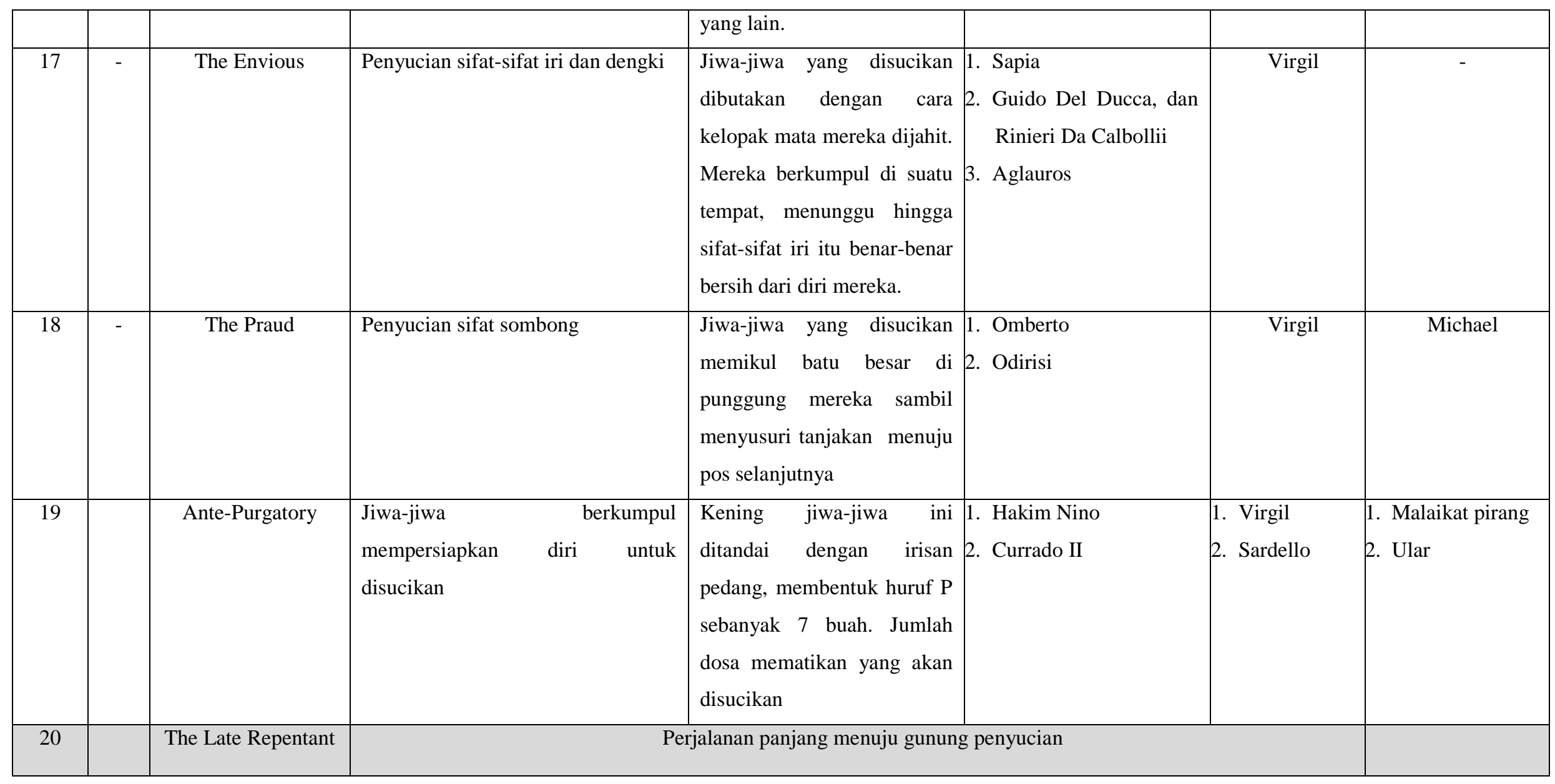




\begin{tabular}{|c|c|c|c|c|c|c|}
\hline 1 & $\begin{array}{c}\text { The Negligent } \\
\text { Rulers }\end{array}$ & Penegak hukum yang lalai & 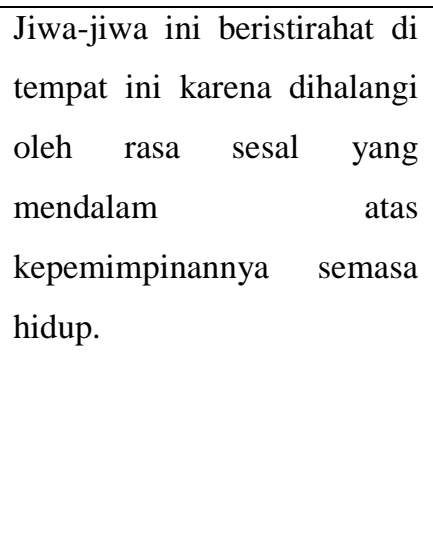 & $\begin{array}{l}\text { 1. King Rudolph, Ottakar } \\
\text { II, Philip IV, Henry I, } \\
\text { dan Peter III } \\
\text { 2. Charles I, dan Alonzo } \\
\text { III, Pedro III } \\
\text { 3. Charles II, Costanza, } \\
\text { dan Henry III. } \\
\text { 4. Edward I, dan William } \\
\text { Marquiz }\end{array}$ & $\begin{array}{l}\text { Virgil } \\
\text { Sordello }\end{array}$ & \\
\hline 2 & The unabsolved & $\begin{array}{l}\text { Jiwa-jiwa yang menghadapi } \\
\text { kematian yang menyiksa, namun } \\
\text { menyempatkan diri bertobat } \\
\text { sebelum detik-detik kematian tiba }\end{array}$ & $\begin{array}{l}\text { Jiwa-jiwa tersebut masih } \\
\text { menyimpan dendam, } \\
\text { sehingga mereka tidak } \\
\text { diperkenankan melanjutkan } \\
\text { perjalanan }\end{array}$ & $\begin{array}{l}\text { 1. Jacopo Del Cassero } \\
\text { 2. Beloconte Da } \\
\text { Montefeltro } \\
\text { 3. La Pia } \\
\text { 4. } \text { Benincasa, Federigo, } \\
\text { Prince Orso, dan Pierre } \\
\text { Dela Brosse } \\
\text { 5. Sardello De Mantoa }\end{array}$ & Virgil & \\
\hline 3 & The indolent & Jiwa-jiwa putus asa & $\begin{array}{l}\text { Mereka berbaring menunggu } \\
\text { do'a dari manusia (keluarga) } \\
\text { yang masih hidup agar bisa } \\
\text { melanjutkan perjalanan }\end{array}$ & Belacqua & Virgil & \\
\hline 4 & Excommunicate & Jiwa-jiwa yang terkucilkan, baru & Menjelajahi samudera yang & 1. Casella & Virgil & 1. Angel \\
\hline
\end{tabular}




\begin{tabular}{|c|c|c|c|c|c|c|c|}
\hline & & & saja meninggal & teramat luas & 2. Manfred & & 2. Cato \\
\hline \multicolumn{8}{|c|}{ INFERNO } \\
\hline \multirow[t]{2}{*}{21} & - & Limbo (earthly hell) & $\begin{array}{l}\text { Pecundang, tanpa kebaikan, serta } \\
\text { kejahatan }\end{array}$ & $\begin{array}{l}\text { Telanjang, menunggu di } \\
\text { sungai yang busuk, } \\
\text { berlumpur, dikerumuni } \\
\text { belatung dan kutu }\end{array}$ & Pope Calestine V & \multirow[t]{2}{*}{ Virgil } & \multirow[t]{2}{*}{ Charon } \\
\hline & & & $\begin{array}{l}\text { Orang-orang baik yang terlahir } \\
\text { pagan; hidup sebelum kelahiran } \\
\text { Yesus; dan, yang meninggal tanpa } \\
\text { dibaptis }\end{array}$ & $\begin{array}{l}\text { Berkumpul di lembah } \\
\text { berbatu dengan cahaya } \\
\text { matahari yang cukup. }\end{array}$ & $\begin{array}{l}\text { 1. Homer, Horace dan } \\
\text { Ovid } \\
\text { 2. Lucan, Hector, Aeneas, } \\
\text { Caesar, Latinus, dan } \\
\text { Lavinia } \\
\text { 3. Socrates, Plato, dan } \\
\text { Aristoteles, Camila, } \\
\text { Panthesilea } \\
\text { 4. Saladin } \\
\text { 5. Tarquin, Lucretia, } \\
\text { Marcia, dan Cornelia. } \\
\text { 6. Democritus, Diogenes, } \\
\text { Heraclitus, } \\
\text { Empedocles, Thales, } \\
\text { Anaxagoras, Zeno, } \\
\text { 7. Dioscorides, Orpheus, }\end{array}$ & & \\
\hline
\end{tabular}




\begin{tabular}{|c|c|c|c|c|c|c|c|}
\hline & & & & & $\begin{array}{l}\text { Linus, Tully, dan } \\
\text { Seneca. } \\
\text { 8. Euclid, Ibnu Rush, } \\
\text { Galen, Ibnu Sina, dan } \\
\text { Hippocrates, }\end{array}$ & & \\
\hline 22 & - & Lust & $\begin{array}{l}\text { Orang-orang yang semasa hidup } \\
\text { dimabuk cinta, sehingga } \\
\text { membahayakan nyawanya dan } \\
\text { orang lain }\end{array}$ & $\begin{array}{l}\text { Dihantui kegelapan, angin } \\
\text { kencang, dan kesendirian } \\
\text { yang abadi }\end{array}$ & $\begin{array}{l}\text { 1. Semiramis, Dido, } \\
\text { Cleopatra, Helen dan } \\
\text { Paris. } \\
\text { 2. Frensisca de Remini }\end{array}$ & Virgil & Minos \\
\hline 23 & - & Gluttony & $\begin{array}{l}\text { Orang-orang yang semasa hidup } \\
\text { sangat rakus }\end{array}$ & $\begin{array}{l}\text { Dihujani lumpur busuk, dan } \\
\text { mereka dibuat lapar } \\
\text { sehingga mereka memakan } \\
\text { lumpur seperti seekor babi }\end{array}$ & Ciaccio & Virgil & Carberus \\
\hline 24 & - & $\begin{array}{c}\text { Avarice and } \\
\text { Prodigal }\end{array}$ & Orang-orang boros dan pelit & $\begin{array}{l}\text { Mendorong batu besar yang } \\
\text { terbuat dari emas, sebagian } \\
\text { (pemboros) berusaha } \\
\text { menukarnya dengan }\end{array}$ & - & Virgil & Plutus \\
\hline
\end{tabular}




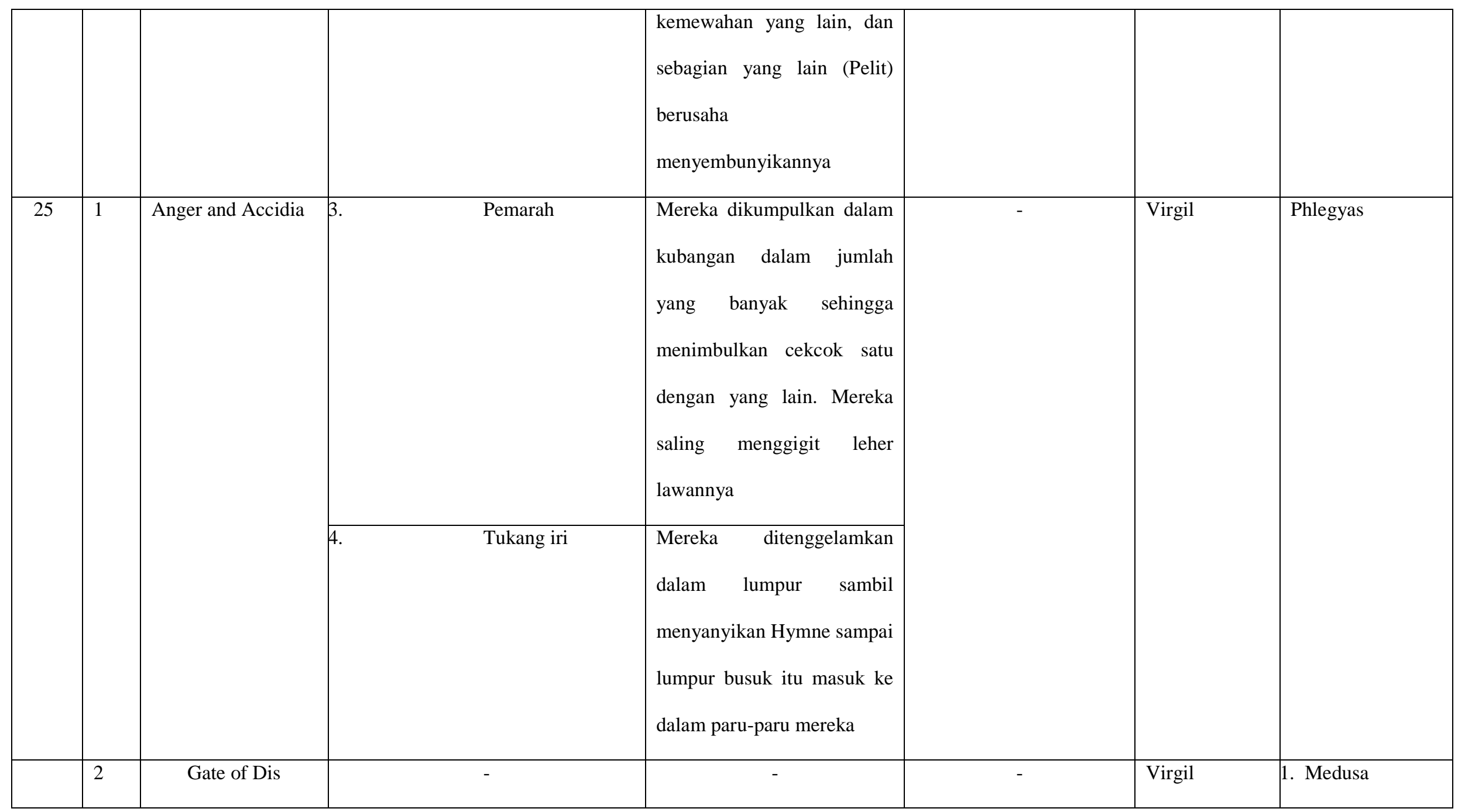




\begin{tabular}{|c|c|c|c|c|c|c|c|}
\hline & & & & & & & $\begin{array}{l}\text { 2. Magaera, } \\
\text { Alecto, dan } \\
\text { Tisiphone }\end{array}$ \\
\hline 26 & - & Heretics & $\begin{array}{l}\text { Pelaku bid'ah, dan pemecah } \\
\text { persatuan gereja }\end{array}$ & $\begin{array}{l}\text { Mereka dimasukkan ke } \\
\text { dalam makam, lalu makam } \\
\text { tersebut dibakar, sehingga } \\
\text { jiwa dalam makam itu } \\
\text { bangkit kepanasan. }\end{array}$ & $\begin{array}{l}\text { 1. Farinata } \\
\text { 2. Cavalcante } \\
\text { 3. Epicurus } \\
\text { 4. } \text { Frederick II }\end{array}$ & Virgil & - \\
\hline 27 & & Violence & \multicolumn{4}{|c|}{ Pelaku Kekerasan dan Menyakiti } & \\
\hline & 1 & $\begin{array}{c}\text { Violence against } \\
\text { Others }\end{array}$ & Pembunuh, perampok, dan penjarah & $\begin{array}{l}\text { Direndam ke dalam sungai } \\
\text { darah dan nanah yang } \\
\text { mendidih, } \\
\text { Kedalaman rendamannya } \\
\text { diatur berdasarkan jumlah } \\
\text { manusia yang dibunuh. } \\
\text { Semakin dalam semakin } \\
\text { biadab }\end{array}$ & $\begin{array}{l}\text { 1. Theseus } \\
\text { 2. Alexander agung, } \\
\text { Dionysius, Ezolino, } \\
\text { dan Obizzo } \\
\text { 3. Guy de Montfort } \\
\text { 4. Attila, dan Pirus } \\
\text { 5. Rinier Pazzo, dan } \\
\text { Rinier da Cornetto }\end{array}$ & $\begin{array}{l}\text { 1. Virgil } \\
\text { 2. Nessus }\end{array}$ & $\begin{array}{l}\text { 1. Minotaur } \\
\text { 2. Centaurs } \\
\text { 3. Chiron } \\
\text { 4. Pholus }\end{array}$ \\
\hline
\end{tabular}




\begin{tabular}{|c|c|c|c|c|c|c|}
\hline 2 & $\begin{array}{c}\text { Violence against } \\
\text { Themselves }\end{array}$ & Pelaku bunuh diri & $\begin{array}{l}\text { Tubuh mereka bercabang, } \\
\text { memiliki ranting, dan } \\
\text { masing-masing rantingnya } \\
\text { ditumbuhi daun. Mereka } \\
\text { menjadi pohon. Tempat } \\
\text { tersebut juga dihuni burung } \\
\text { Herpy yang memakan } \\
\text { dedaunan yang ada disana. }\end{array}$ & $\begin{array}{l}\text { 1. Pierre della Vigna } \\
\text { 2. Lano } \\
\text { 3. Jacopo da Santo } \\
\text { Andrea } \\
\text { 4. Rocco de Mozzi }\end{array}$ & Virgil & Burung Harpy \\
\hline 3 & $\begin{array}{ll}\text { Violence against } \\
\text { God }\end{array}$ & Para takabur, menantang Tuhan & $\begin{array}{l}\text { Mereka dikumpulkan di } \\
\text { sebuah padang pasir yang } \\
\text { kering, dan panas akibat } \\
\text { hujan lava. }\end{array}$ & - & Virgil & Capaneus \\
\hline
\end{tabular}




\begin{tabular}{|c|c|c|c|c|c|c|c|}
\hline & & & & seekor kambing. & $\begin{array}{l}\text { Tegghiaio Aldobrandi, } \\
\text { dan Jacopo Rusticucci } \\
\text { 4. Vitaliano }\end{array}$ & & \\
\hline \multirow[t]{3}{*}{28} & & Malebogne & \multicolumn{4}{|c|}{ Pelaku Penipuan Tingkat Rendah } & \\
\hline & 2 & Flatters & Para penjilat & $\begin{array}{l}\text { Rasa gatal di kepala mereka, } \\
\text { sehingga semakin mereka } \\
\text { menggaruknya semakin } \\
\text { mengelupas pula kulit } \\
\text { kepala mereka }\end{array}$ & Alessio Intermenici & Virgil & - \\
\hline & 3 & Simoniac & $\begin{array}{l}\text { Tukang sogok, penerima suap, dan } \\
\text { pelaku nepotisme }\end{array}$ & $\begin{array}{l}\text { Tubuh mereka tertancap } \\
\text { dalam tanah dengan posisi } \\
\text { terbalik, sehingga yang } \\
\text { tampak hanya kaki yang }\end{array}$ & $\begin{array}{l}\text { 1. Paus Nicholas II } \\
\text { 2. Paus Boniface VIII }\end{array}$ & Virgil & - \\
\hline
\end{tabular}




\begin{tabular}{|c|c|c|c|c|c|c|}
\hline & & & bergerak minta tolong. & & & \\
\hline 4 & Soothsayers & Para astrolog, peramal dan penyihir & $\begin{array}{l}\text { Kepala mereka diplintir } \\
\text { hingga wajahnya menghadap } \\
\text { kebelakang. Memberi kesan } \\
\text { bahwa mereka tidak bisa } \\
\text { membedakan mana berjalan } \\
\text { mundur atau maju. }\end{array}$ & $\begin{array}{l}\text { 1. Tiresias, Amphiarus, } \\
\text { Aruns, dan Manto. } \\
\text { 2. Calehas, Michael Scot, } \\
\text { GuidoBonati Asdante }\end{array}$ & Virgil & - \\
\hline 5 & Barrator & Pemfitnah, dan pengadu domba & $\begin{array}{l}\text { Seperti permainan drama, } \\
\text { mereka terdesak untuk } \\
\text { mengamankan diri mereka } \\
\text { dengan mengadu domba } \\
\text { sesama iblis penjaga. } \\
\text { Dengan begitu penjaga- } \\
\text { penjaga itu bersiteru satu } \\
\text { sama lain. Namun, itu tidak } \\
\text { berlangsung lama. mereka } \\
\text { akan menyaadari mereka }\end{array}$ & $\begin{array}{l}\text { 3. Fra Gomita } \\
\text { 4. Dol Michele Zenche }\end{array}$ & $\begin{array}{l}\text { Virgil dan } 10 \\
\text { anak buah } \\
\text { Malacoda }\end{array}$ & $\begin{array}{l}\text { 1. Malacoda } \\
\text { 2. Scarmiglione } \\
\text { 3. Anak buah } \\
\text { Malacoda: } \\
\text { Ciriatto, } \\
\text { Libicocco, } \\
\text { Draghignazze, } \\
\text { Farfalecco, } \\
\text { Alinchino, } \\
\text { Barbaniccia, }\end{array}$ \\
\hline
\end{tabular}




\begin{tabular}{|c|c|c|c|c|c|c|}
\hline & & & $\begin{array}{l}\text { diadu domba oleh salah satu } \\
\text { pendosa. Si pendosa pun jadi } \\
\text { bulan-bulanan iblis penjaga }\end{array}$ & & & $\begin{array}{l}\text { Grafficane, } \\
\text { Pubicante, } \\
\text { Cagnazzo, dan } \\
\text { Calacabrina }\end{array}$ \\
\hline 6 & Hypocrites & Orang-orang munafik & $\begin{array}{l}\text { Mereka mengenakan zirah } \\
\text { perang yang terbuat dari } \\
\text { timbal yang berat, berjalan } \\
\text { jauh dan curam }\end{array}$ & $\begin{array}{l}\text { 1. Fra Catalano } \\
\text { 2. Kayafas }\end{array}$ & Virgil & - \\
\hline 7 & Thieves & Pencuri & $\begin{array}{l}\text { Pendosa dililiti ular piton } \\
\text { yang besar yang tidak lain } \\
\text { wujud dari pendosa yang } \\
\text { lain. Setelah tulang pendosa } \\
\text { remuk, ular tersebut kembali } \\
\text { ke wujud manusia, lalu } \\
\text { manusia yang telah remuk } \\
\text { itu berubah wujud menjadi } \\
\text { ular, untuk selanjutnya }\end{array}$ & $\begin{array}{l}\text { 1. Vanni Fucci } \\
\text { 2. Agnello } \\
\text { 3. Puccio Sciancato, } \\
\text { Gaville }\end{array}$ & Virgil & $\begin{array}{l}\text { 1. Ciafna } \\
\text { 2. Centaur }\end{array}$ \\
\hline
\end{tabular}




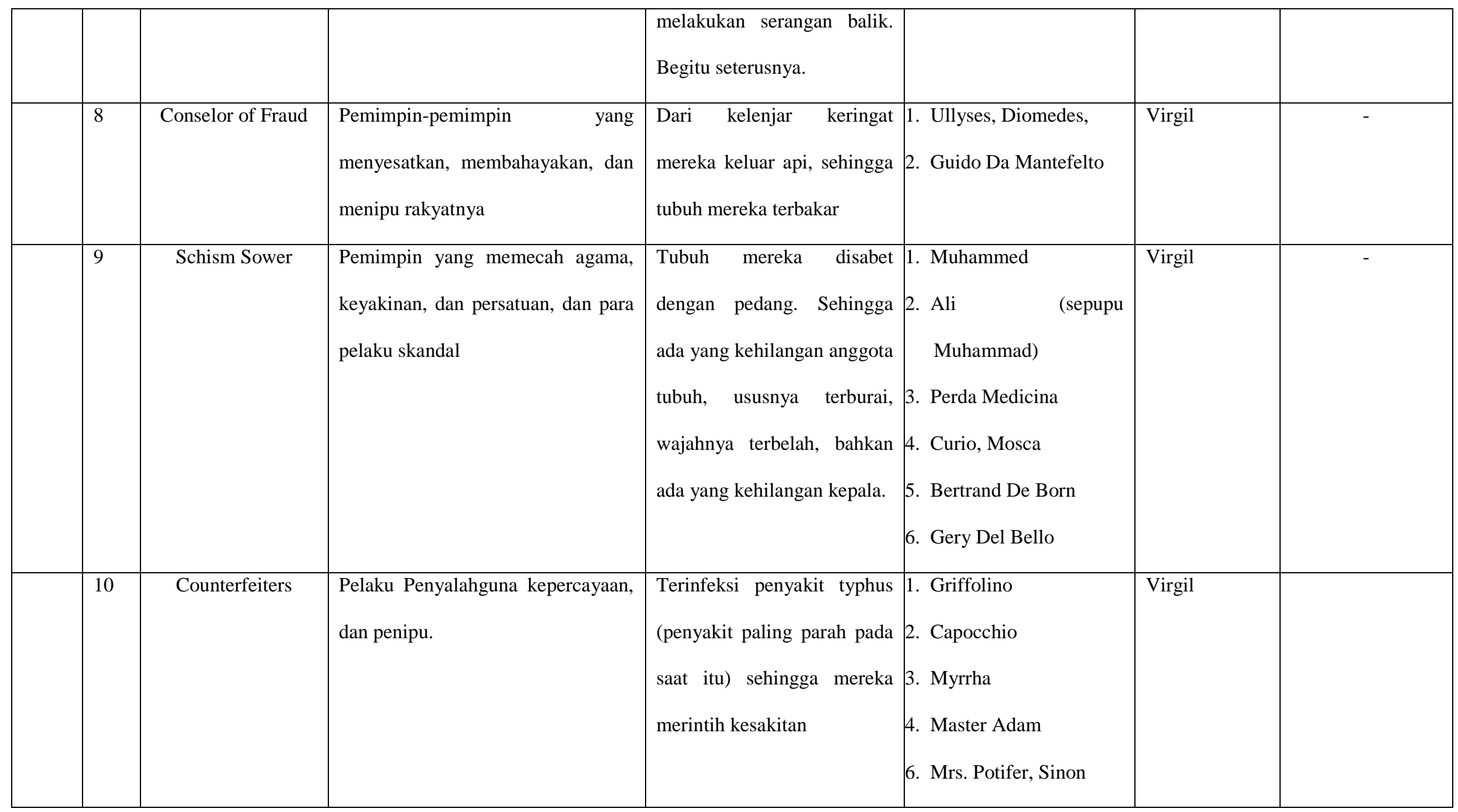




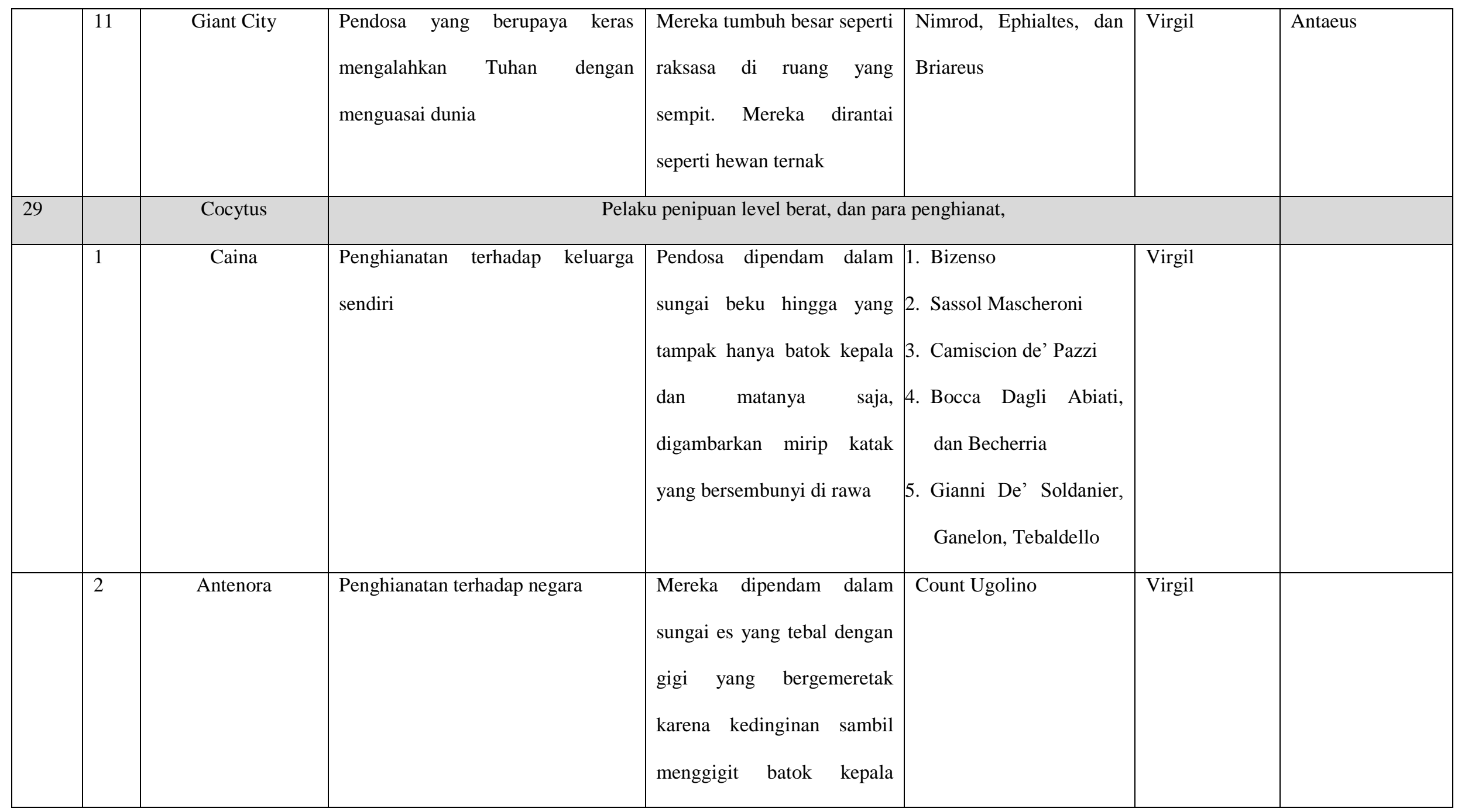




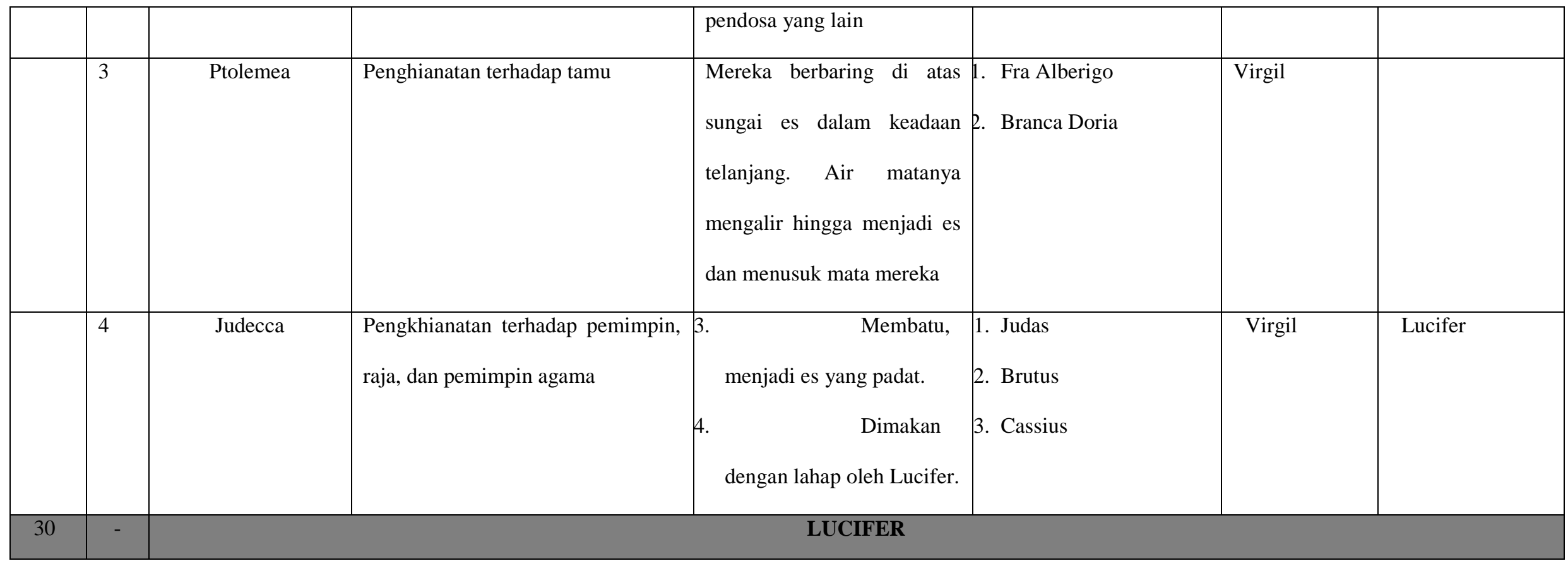

Tabel 2.3 Tabel susunan ulang eskatologi The Divine Comedy yang diurut berdasarkan hirarki paling mulia hingga yang paling hina 
Setelah memperhatikan susunan hirarki di atas, dapat disimpulkan bahwa eskatologi The Divine Comedy adalah sebuah bangunan teks yang disusun secara hirarkis. Teks mendikte moralitas, sehingga pembaca pada masanya bukan hanya sekedar memandang commedia sebagai sebuah bacaan tetapi sebuah totalitas representasi dari apa yang mereka yakini. Logos secara terang-terangan hadir di dalam teks. Hanya saja Logos dalam hal ini masih merupakan prinsip yang masih primitif karena bersifat teosentris. Oleh karena itu, kenyataan bahwa gereja, setelah trilogi Commedia ini diterbitkan, memanfaatkan kegelisahan umat Kristen pasca membacanya, untuk menggiring kembali domba-domba yang sesat adalah benar adanya. Itulah salah satu sebab mengapa Puisi Dante ini menjadi sangat popular dan dijaga kemisteriusannya.

Keyakinan Derrida bahwa sistem tertutup dalam teks atau dikenal dengan difference telah menghasilkan hirarki telah terbukti dari pemaparan di atas. Namun, perlu diketahui bahwa strukturasi teks The Divine Comedy semata-mata digunakan untuk kepentingan dekonstruksi teks tersebut yang terdapat di dalam Novel Inferno karya Dan Brown. Commedia merupakan mahakarya abad pertengahan yang hingga hari ini masih diperbincangkan dan diagungkan sebagai karya sastra dengan konsep estetika yang sangat luar biasa. Pembahasan mengenai teks tersebut tidak akan cukup hanya dengan penjelasan satu bab ini. Oleh karena itu, peneliti membatasi hanya pada hal-hal yang memungkinkan untuk didekonstruksi oleh novel Dan Brown yang terbit tahun 2013 ini.

Untuk mempertegas konsep kehadiran dalam teks commedia, berikut ini akan ditampilkan 100 oposisi berpasangan yang dipandang cukup untuk mengenal 
sejauh mana ideologi pengarang memapankan hirarkinya di dalam teks, dan juga paling mungkin untuk mengalami dekonstruksi dalam novel Inferno karya Dan Brown.

\begin{tabular}{|c|c|c|}
\hline NO & \multicolumn{2}{|c|}{ Oposisi Berpasangan } \\
\hline 1 & Direct & Ambigous \\
\hline 2 & Eternal & Mortal \\
\hline 3 & Montain's Summit & Montain's foot \\
\hline 4 & Paradise & Hell \\
\hline 5 & Shade & Human \\
\hline 6 & Collect & Waste \\
\hline 7 & Human & Animal \\
\hline 8 & Eagle & Insect \\
\hline 9 & Fatten-up & Thin-down \\
\hline 10 & Man & Lady \\
\hline 11 & Glory & Lowliness \\
\hline 12 & Europe & Saracen (Arab) \\
\hline 13 & Christian & Moslem \\
\hline 14 & Light & Dark \\
\hline 15 & Sweet & Bitter \\
\hline 16 & Master & Student \\
\hline 17 & Day & Night \\
\hline 18 & Fire & Water \\
\hline 19 & Air & Earth \\
\hline 20 & Up & Down \\
\hline
\end{tabular}




\begin{tabular}{|c|c|c|}
\hline 21 & Civilized & Barbarian \\
\hline 22 & Charity & Sin \\
\hline 23 & Angel & Devil \\
\hline 24 & Lamp & Shadow \\
\hline 25 & Chosen & Ignored \\
\hline 26 & Brave & Fear \\
\hline 27 & Scan & Forget \\
\hline 28 & True & False \\
\hline 29 & Confidence & Terror \\
\hline 30 & Blessed & Condemned \\
\hline 31 & Come & Go \\
\hline 32 & Nymph & Beast \\
\hline 33 & Hope & Hopeless \\
\hline 34 & Pleasant & Gloomy \\
\hline 35 & Patriarch & Peasant \\
\hline 36 & Patience & Anger \\
\hline 37 & Praise & Blame \\
\hline 38 & Montain & Valley \\
\hline 39 & Love & Envy \\
\hline 40 & Aware & Blind \\
\hline 41 & Run & Walk \\
\hline 42 & Recognize & Refuse \\
\hline 43 & Sun & Moon \\
\hline 44 & Spirit & Body \\
\hline
\end{tabular}




\begin{tabular}{|c|c|c|}
\hline 45 & Joyful & Hopeless \\
\hline 46 & Good & Evil \\
\hline 47 & Sufficient & Little-failing \\
\hline 48 & Center & Marginal \\
\hline 49 & Follow & Leave \\
\hline 50 & Right & Left \\
\hline 51 & Flying & Swimming \\
\hline 52 & Knight & Loser \\
\hline 53 & Adam & Eve \\
\hline 54 & Cold & Hot \\
\hline 55 & Trust & Distrust \\
\hline 56 & Smile & Cry \\
\hline 57 & Polite & Impolite \\
\hline 58 & Kind & Mischievous \\
\hline 59 & Silence & Noise \\
\hline 60 & Mercy & Disdail \\
\hline 61 & Mockery & Flattery \\
\hline 62 & Joy & Solitude \\
\hline 63 & Peace & War \\
\hline 64 & Cry out & Hide \\
\hline 65 & Engage & Force \\
\hline 66 & Gold & Rock \\
\hline 67 & Harmony & Schism \\
\hline 68 & Gladsome & Weeping \\
\hline
\end{tabular}




\begin{tabular}{|c|c|c|}
\hline 69 & Genius & Lack \\
\hline 70 & Musical & Dissonant \\
\hline 71 & Diligent & Indolent \\
\hline 72 & Rich & Poor \\
\hline 73 & New & Old \\
\hline 74 & Falcon & Mouse \\
\hline 75 & Monk & Villain \\
\hline 76 & Honest & Hypocrite \\
\hline 77 & Milk & Poison \\
\hline 78 & Mother & Father \\
\hline 79 & Illumination & Stupidity \\
\hline 80 & Angelic & Demonic \\
\hline 81 & Prophetic soul & Sinful soul \\
\hline 82 & Divine & Ungodly \\
\hline 83 & Wisdom & Fool \\
\hline 84 & Summer & Winter \\
\hline 85 & Rise & Fall \\
\hline 86 & Mature & Childish \\
\hline 87 & Lustre & Dirty \\
\hline 88 & Strong & Weak \\
\hline 89 & Splendour & Poorness \\
\hline 90 & Greece & Roman \\
\hline 91 & Health & Disease \\
\hline 92 & Praise & Discredit \\
\hline
\end{tabular}




\begin{tabular}{|c|l|l|}
\hline 93 & Joy & Pity \\
\hline 94 & Respectable & Shameful \\
\hline 95 & Observe & Glimpse \\
\hline 96 & Mild & Loud \\
\hline 97 & North & South \\
\hline 98 & Wings & Horns \\
\hline 99 & Welcome & Exile \\
\hline 100 & God & Lucifer \\
\hline
\end{tabular}

Tabel 2.4 Tabel oposisi berpasangan The Divine Comedy

Dengan memperhatikan oposisi berpasangan tersebut di atas, dapat dengan jelas terlihat bahwa penyair mempertahankan suatu ideologi dengan melegitimasi simbol-simbol keabadian, sikap moral, kekuasaan, nilai agama tertentu, gender tertentu, dan ras tertentu. Simbol keabadian disini dapat dilihat pada nomor 2, 4, 5, 20, 44 dan 100. Perbandingan itu menunjukkan adanya keutamaan Eternal daripada Mortal, Paradise daripada Hell, Shade and human, Spirit daripada body, God daripada Lucifer. Simbol-simbol keabadian ini cenderung meligitimasi adanya kekuatan supranatural yang berkuasa atas kehidupan di seluruh jagad. Oposisi yang mendukung simbol-simbol keabadian juga tampak pada nomor 19 antara air dan earth; dan, nomor 24 antara lamp dan shadow. Udara (air) dan pusat cahaya (lamp) dianggap berada di ruang yang tidak terjangkau oleh indera, sehingga kedua zat tersebut menduduki tempat yang lebih mulia dibandingkan bumi. Sedangkan bayangan sendiri, walaupun tidak diinderai dalam hal ini alat 
peraba, sering dijadikan sebagai sebuah legitimasi adanya ruang yang terhindar oleh pengamatan cahaya.

Sikap moral tertentu meliputi oposisi nomor 7, 21, 22, 23, 28, 30, 33, 36, 37, 39, 50, 67, 76, dan 83. Sikap yang mengoposisi seperti human, civilized, charity, angel, true, blessed, hope, praise dan seterusnya menunjukkan sikap yang beradab. Sikap-sikap ini menunjukkan konsekuensi logis atas perbuatan-perbuatan baik mereka. Apabila mereka mengabaikan sikap mulia tersebut atau melanggar perbuatan mulia tersebut maka konsekuensinya mereka dituding sebagai animal, barbarian, devil, dan seterusnya. Oposisi kekuasaan juga tampak jelas dari tabel di atas. Ini dapat dilihat pada pasangan nomor $8,11,16,35,48,52,63,72,74$, dan 85. Kekuasaan ini meliputi simbol-simbol kejayaan bangsa Romawi/Itali seperti eagle, atau falcon yang beroposisi pada hewan-hewan lemah atau pecundang seperti insect dan mouse. Adapun kelas masyarakat yang mulia dan dihormati meliputi patriarch, rich, master, knight, yang beroposisi dengan peasant, poor, student, loser.

Sikap agama, ras dan gender tertentu meliputi pasangan nomor 10, 12, 13, 53, dan 90. Dari oposisi berpasangan ini dapat diketahui identitas penyair dengan memperhatikan semangat patriotisme yang dia miliki. Dante lebih mengutamakan bangsa Europe daripada bangsa Saracen. Saracen adalah nama untuk bangsa Arab yang diberikan oleh orang-orang Italia dengan konotasi yang negatif. Dengan terang, dia mendeklarasikan dirinya seorang Christian dan merendahkan umat-umat yang lain, terutama Moslem. Namun, dalam segi kebudayaan dan seni ia masih mengunggulkan bangsa Greece daripada bangsanya 
sendiri, Roman. Adam dan Eve adalah dua tokoh yang mewakili gendernya masing-masing dimana Adam sebagai seorang man masih lebih diutamakan dibandingkan Eve yang mewakili gender lady. Namun, teks Dante pada akhirnya menawarkan jejak dimana jika penanda-penanda di dalam oposisi ini disebar, maka penanda-penanda tersebut menghasilkan pola yang asing dari teks aslinya, sebagaiman yang Dante lakukan dalam membaptis tokoh mitologi pagan ke dalam The Divine Comedy.

Setelah menstrukturasi pemikiran Dante, dan pendiktean teks yang dilakukannya, serta menemukan trace di dalam The Divine Comedy, bab selanjutnya akan dibahas mengenai dekonstruksi teks/puisi tersebut di dalam novel Inferno karya Dan Brown. 


\section{BAB III}

\section{DEKONSTRUKI DALAM NOVEL INFERNO}

Inferno, seperti halnya petualangan Robert Langdon dalam tiga novel sebelumnya, menjadi novel yang mengajak pembacanya berwisata menelusuri jejak-jejak karya seni yang dipengaruhi The Divine Comedy karya Dante Alighieri sepanjang Florence dan belahan dunia Eropa lainnya. Sebagai sebuah fiksi pop yang mendeklarasikan teksnya yang berhipogram Commedia Dante, novel karya Dan Brown ini tidak akan melakukan aksi dekonstruksi teks apapun, selama itu tidak bertujuan mengejar selera pembacanya. Namun, pengarang novel The $D a$ Vinci Code ini telah memiliki karakteristik dalam menerbitkan fiksi yang diminati pembacanya di seluruh dunia, yaitu informatif, kontroversi, dan fakta-fakta yang mencengangkan. Hal ini disebabkan Dan Brown sangat peka pada konteks, bahkan dengan menyelipkan konteks tersebut Brown menjadi pengarang terbaik di milenium ketiga versi Majalah Time. Oleh karena itu, dengan menghadirkan konteks kekinian wacana Commedia di dalam novel Inferno, Dan Brown bukan hanya sekadar menciptakan bacaan yang menarik tetapi di saat yang bersamaan mendekonstruksi The Divine Comedy.

\subsection{Ringkasan Novel Inferno}

Novel Inferno merupakan satu dari empat novel karya Dan Brown yang bertokoh sentral Robert Langdon. Inferno menceritakan profesor psikopat yang berhasil merekayasa virus untuk mengurangi jumlah populasi manusia di bumi secara massif. Ia memasukkan virusnya ke sebuah wadah dan menyimpannya di 
suatu tempat yang hanya bisa diketahui dengan memecahkan clue melalui simbolsimbol yang terdapat di dalam puisi The Divine Comedy. Sebagai seorang simbolog, Prof. Robert Langdon diminta segera memecahkan kode-kode tersebut oleh organisasi kesehatan dunia WHO. Sayangnya, di tempat lain ada beberapa pihak yang memiliki kepentingan berbeda juga memanfaatkan Langdon untuk mencari tahu letak penyimpanan virus tersebut sebelum wadah sensitif itu mencair. Dari perjalanannya menelusuri kota-kota yang menyisakan jejak Dante serta pengamatan terhadap karya-karya seni yang terinspirasi oleh Commedia, Langdon dan kawan-kawannya menemukan banyak kearifan, selain berupaya menemukan virus berbahaya yang dinamakan Inferno tersebut.

\subsection{Persinggungan Dua Ilham}

Dari ringkasan di atas, dapat diperhatikan bahwa novel Inferno karya Dan Brown ini merupakan reaksi terhadap pembacaan aktif teks puisi The Divine Comedy karya Dante Alighieri. Teks demi teks, serta kutipan demi kutipan Commedia menyebar di belantara teks novel Inferno, untuk memenuhi janji pembacanya. Untuk menjangkau tangensial dua teks tersebut, dan untuk kepentingan observasi, peneliti membagi dua bentuk persinggungan, yaitu persinggungan berupa teks yang meliputi kutipan-kutipan puisi Dante yang secara eksplisit tampak di dalam novel, dan persinggungan berupa simbol, yang meliputi karya-karya seni yang mengangkat bagian puisi Dante, dan tokoh-tokoh yang dialegori Dante. 


\subsubsection{Persinggungan berupa Idiom}

Novel terbaru Dan Brown ini menghadirkan teks-teks Commedia dalam beberapa bentuk. Sebelum memaparkan bentuk-bentuk tersebut karena teks The Divine Comedy bahasa asalnya adalah Bahasa Itali kuno, maka kutipan-kutipan teks Commedia di dalam novel Inferno ditulis dalam Bahasa Inggris. Hingga kini terdapat lebih dari tujuh terjemahan Commedia ke dalam bahasa Inggris. Pengarang memilih terjemahan Commedia oleh Wodsworth Longfellow. Ini sedikit akan berbeda, sebagaimana dijelaskan di bab awal, peneliti menggunakan C.W Eliot. Brown mengakui dengan terang bahwa terjemahan yang digunakannya adalah Wadsworth Longfellow, berikut kutipan dan alasan Brown memilih Wodsworth Longfellow:

Dante Alighieri had evolved into one of history's true cult icons, sparking the creation of Dante societies all around the world. The oldest American branch had been founded in 1881 in Cambridge, Massachusetts, by Henry Wadsworth Longfellow. New England's famous fireside Poet was the first American to translate The Divine Comedy, his translation remaining among the most respected and widely read to this day. (Brown, 2013: 81) [Dante Alighieri telah berkembang menjadi salah satu ikon pujaan sejati dalam sejarah, mencetuskan pembentukan perhimpunan Dante di seluruh dunia. Cabang Amerika yang tertua dibentuk pada 1881 di Cambridge, Massachussets, oleh Henry Wodsworth Longfellow, Penyair Kelompok Fireside terkenal dari New England itu adalah orang pertama yang menerjemahkan The Divine Comedy, terjemahannya tetap menjadi salah satu yang paling dihormati dan banyak dibaca hingga hari ini.]

Oleh karena itu, hal ini dapat dimaklumi jika terjadi perbedaan dalam pemilihan diksi.

Berikut ini bentuk-bentuk persinggungan yang dapat diperhatikan dalam teks novel Inferno yang dikutip dari hipogramnya The Divine Comedy. Pertama, 
teks Commedia hadir sebagai sebuah informasi. Sebagaimana petualanganpetualangan sebelumnya, Novel-novel karya Dan Brown yang bertokoh sentral Robert Langdon, banyak narasi atau penjelasan Langdon sebagai guide yang memaparkan maksud dari karya seni tertentu, atau asal-usul simbol dan karya seni tersebut. Dalam Inferno, Dan Brown juga melakukan teknik yang sama, terutama dalam menjelaskan kutipan-kutipan popular dalam The Divine Comedy. Biasanya hal ini dilakukan di sebuah forum resmi, tentu saja Langdon yang menjadi pembicara. Yang paling sering terjadi adalah ketika berhayal, flash-back atau mengingat-ingat dirinya sewaktu membawakan kuliah umum. Kutipan berikut adalah salah satu contohnya.

Langdon moved to the next slide-a Gustave Dore lithograph that depicted a dark, tunneled entrance carved into the face of an austere cliff. The inscription above the door read: ABANDON ALL HOPE, YE WHO ENTER HERE

"So..." Langdon said with a smile. "Shall we enter?" (Brown, 2013; 85) [Langdon berpidah ke slide berikutnya - litografi Gustav Dore yang menggambarkan pintu masuk terowongan gelap di sebuah tebing yang kokoh. Tulisan di atas pintu berbunyi: TINGGALKAN SEMUA HARAPAN, WAHAI KALIAN YANG MASUK KE SINI masuk?"]

"Jadi..." kata Langdon sambil tersenyum. “Akankah kita

Robert Langdon, diceritakan, sedang menghadiri undangan sebagai pembicara di forum raksasa. Ia diminta membawakan kuliah umum mengenai puisi The Divine Comedy karya Dante. Kalimat dengan huruf-huruf kapital dalam kutipan di atas adalah salah satu kalimat populer dalam Commedia.

\section{“...Before me, things create were none save things}

Eternal, and eternal I endure. 
All hope abandon, ye who enter here" (Inferno 3: 13)

["di hadapanku, segala sesuatunya diciptakan tak lain untuk menjadi abadi, dan kekallah aku bertahan. Tinggalkan semua harapan wahai engkau yang masuk ke sni”]

Langdon dan narasi tidak memberikan penjelasan apapun mengenai kalimat "Abandon all hope, ye who enter here". Hanya sebuah kalimat yang diucapkan Langdon "so shall we enter?" yang ditambah dengan pertanyaan retorik. Selanjutnya, pertanyaan tersebut diikuti dengan narasi berupa ekspresi with a smile. Hal Ini sudah cukup untuk menggambarkan bahwa pekerjaan demikian, yaitu memasuki tempat yang berbahaya dengan peringatan di dinding tersebut, hanya pantas dilakukan oleh Dante dan bangsa hantu. Untuk mempertegas kepopuleran kutipan Dante tersebut Brown mengulasnya lagi dalamkesempatan yang lain, berikut dengan penjelasannya. ch'entrate."

"Lasciate ogne speranza," they were now chanting, "voi

These six words - the most famous line in all of Dante's Infernowelled up from the bottom of the stairs like the ominous stench of death.

Accompanied by swell of trumpets and horns, the choir intoned the warning again. "Lasciate ogne speranza voi ch'entrate!"

Abandon all hope, yewho enter here! (Brown, 2013: 405) [Lasciate ogne speranza," mereka menyanyikan, "voi ch'entrate",

Enam kata itu - baris paling terkenal dari Inferno karya Dante mengalin dari dasar tangga bagaikan bau busuk kematian.

Diiringi oleh lolongan terompet dan sangkakala, paduan suara menyerukan peringatan itu lagi "Lasciate ogne speranza voi ch'entrate!"

Tinggalkan semu harapan, wahai kalian yang masik kesini!] Contoh selanjutnya ketika Langdon dan Sienna menyeberangi sungai Arno. Di atas jembatan Ponte Vecchio, Langdon tampak mengingat-ingat 
peristiwa tragis yang menimpa Florence yang menjadi benih pertikaian dua kubu besar selama berabad-abad.

To this day, three separteplague-each quoting a different line from Canto 16 of Dante's Paradiso - could be found near the murder site. One of them was situated at the mouth of the Ponte Vecchio and ominously declared:

BUT FLORENCE, IN HER FINAL PEACE, WAS FATED TO OFFER UP UNTO THAT MUTILATED STONE GUARDIAN UPON HER BRIDGE...A VICTIM. (Brown, 2013: 143) [hingga hari ini, tiga plakat terpisah-yang masing-masing mengutip baris berbeda dari Canto 16 Paradiso Dante-bisa ditemukan di dekat tempat pembunuhan itu. Salah satunya terletak di mulut Ponte Vecchio dan menyatakan dengan mengancam

TAPI, FLORENCE, DALAM KEDAMAIAN AKHIRNYA, DITAKDIRKAN UNTUK MENAWARKANKEPADA PENJAGA BATU TERMUTILASI DI ATAS JEMBATANNYA... SEORANG KORBAN]

Telah dijelaskan pada kutipan di atas mengenai maksud kutipan tersebut. Langdon memberikan penjelasan bahwa tulisan prasasti di Ponte Vecchio itu berasal dari Commedia untuk mengabadikan tragedi buruk yang menimpa Florence di masa lalu. Kutipan tersebut juga sudah dijelaskan dalam narasi sebelumnya bahwa puisi tersebut terdapat di dalam Paradiso, canto 16.

Puisi Dante selanjutnya adalah Inferno canto 9:

...Ye of intellect

Sound and entire, mark well the lore conceal'd

Under close texture of the mystic strain (Inferno 9: 37)

[Wahai engkau yang memiliki kecerdasan menangkap, cermatilah dengan seksama ajaran yang bersembunyi di balik ketegangan ini]

Kutipan ini merupakan salah satu clue yang diberikan Zobrist, sosok pencipta terror di dalam novel Inferno, untuk dipecahkan oleh Langdon dan timnya. 
Karena merupakan clue, kutipan ini seringkali muncul meskipun kemunculan lebih sering dalam keadaan tidak utuh. Brown, seperti biasa, memberikan penjelasan atas kutipannya itu.

"As I mentioned earlier," Langdon began, "The opening of Stanza of Zobrist's poem is taken verbatim from Dante's Inferno-an admonition to the reader that the words carry a deeper meaning."

Dante's allegorical work was so replete with veiled commentary on religion, politics, and philosophy that Langdon often suggested to his students that the Italian poet be studied much as one might study the Bible-reading between the lines in an effort to understand the deeper meaning. (Brown, 2013: 275) ["Seperti yang kubilang sebelumnya," kata Langdon memulai, "stanza pembukaan puisi Zobrist ini diambil secara persis dari Inferno-nya Dante - peringatan kepada pembaca bahwa katakata itu mengandung arti yang lebih dalam."

Karya alegoris Dante begitu dipenuhi komentar terselubung mengenai agama, politik, dan filsafat, sehingga Langdon seringkali menyarankan kepada mahasiswanya agar karya penyair Italia itu dianalisis seperti orang yang mempelajari ALkitab - membaca apa yang tersirat dalam upaya memahami arti yang lebih dalam]

Pada kutipan novel Inferno di atas, pengarang menciptakan suasana yang begitu mirip dengan Dante dengan mengingatkan pembacanya agar selalu memandang teks Dante sebagai sebuah sindiran, alegori, metafora, atau jenis-jenis kiasan lainnya. Pengarang Inferno juga mengajak pembacanya untuk ikut berfikir dalam menganalisis rangkaian kalimat selanjutnya sebagai sebuah clue dalam estetika fiksi misteri yang tengah dibaca.

Kutipan dari pembuka puisi Dante juga peneliti masukkan di kategori ini. Walaupun tidak ditulis secara mencolok, potongan puisi ini ditulis secara utuh dansedikit terpisah dari rangkaian teks yang lain. Potongan puisi tersebut ditulis di halaman 77 novel Inferno. 
In the midway of this our mortal life,

I found me in a gloomy wood, astray

Gone from the path direct... (Inferno 1:5)

[di paruh perjalanan hidup kita ini, aku menemukan diriku tersesat di belantara hutan karena jalan lurus itu telah lenyap.]

Adapun puisi Dante yang digunakan sebagai clue dalam novel ini adalah Paradiso canto 25. Diceritakan bahwa sahabat Langdon Ignazio Busoni memberitahukan Langdon letak death mask Dante melalui isyarat dari puisi tersebut.

If e'er the sacred poem, that hath made

Both Heaven and earth copartners in its toil,

And with lean abstinence, through many a year,

Faded my brow, be destined to prevail

Over the cruelty, which bars me forth

Of the fair sheep-fold, where, a sleeping lamb,

The wolves set on and fain had worried me;

With oher voice, and, standing up

At my baptismal font, shall claim the wreath

Due to the poet's temples: for I there

First enter'd on the faith, which maketh souls

Acceptable to God: and for, its sake

Peter had then circled my forehead thus (Paradiso 25: 391)

[jika itu harus terjadi, jika puisi kudus ini, karya yang begitu dicinta langit dan bumi ini, yang membuatku menderita selama bertahuntahun panjang ini, akan pernah mampu menanggulangi kekejaman yang akan menghalangiku dari dekapan kasih tempat kubersemayam, seekor domba melawan serigala yang memeranginya. Saat itu dengan suara berbeda, aku kan kembali sebagai penyair dan mengenakan mahkota daun di tempat baptisanku; sebab di sanalah pertama kali kutemukan jalan 
menuju iman, yang membuat jiwa-jiwa menyambut Tuhan, lalu, karena iman itu, Peter menghiasi alisku.]

Kutipan puisi di atas seperti clue-clue yang lain diulang-ulang dalam beberapa kesempatan. Namun, seperti halnya clue-clue yang lain juga, dengan singkat pengarang memberikan penjelasan ilmiah mengenai maksud puisi tersebut.

Langdon loosely recalled this passage, too - an obliwue reference to a political deal offered to Dante by his enemies.according to history, the "wolves" who banished Dante from Florence had told him he could return to the city only if he agreed to endure a public shaming - that of standing before an entire congregation, alone at his baptismal font, wearing only sackcloth as an admission of the guilt.

In the passage Landon had just read, Dante, having declined the deal, proclaims that if he ever returns to his baptismal font, he will be wearing not the sackcloth of a guilty man but the laurel crown of a poet. (Inferno, 2013: 229) [Langdon samar-samar ingat bait itu - pertunjukan tak langsung pada kesepakatan politik yang ditawarkan kepada Dante oleh musuh-musuhnya. Menurut sejarah, "serigala"yang mengusir Dante dari Florence mengatakan Dante boleh kembali ke kota itu hanya jika dia setuju untuk dipermalukan di hadapan publik - yakni berdiri di hadapan seluruh jema'at, sendirian di tempat baptisannya, hanya mengenakan cawat sebagai pengakuan atas kesalahannya.

Dalam bait yang barusan dibaca Langdon, Dante, setelah menolak kesepakatan itu, menyatakan bahwa jika dia kembali ke tempat baptisannya, dia tak akan mengenakan cawat, melainkan mahkota daun seorang penyair.]

Dari penjelasan mengenai pengutipan teks Dante di atas dapat disimpulkan bahwa teks novel Inferno yang menggunakan kutipan-kutipan puisi Dante dengan huruf kapital, atau berupa clue adalah semata-mata untuk memberikan penjelasan mengenai makna puisi tersebut, sebagaimana penelitian-penelitian mengenai The Divine Comedy yang pernah ada. Tujuan menyisipkan kutipan-kutipan tersebut tidak lain untuk mengenalkan pembaca tentang keagungan karya besar tersebut, serta pengaruhnya yang besar terhadap karya-karya seni, peradaban, dan pelajaran 
yang berkembang setelah puisi ini terbit. Hal ini juga menjadi ciri khusus novelnovel Dan Brown terutama tiga novel petualangan Robert Langdon lainnya, yakni fiksi-fiksi perjalanan Robert Langdon yang memperkenalkan dan menghubungkan karya-karya seni dunia melalui petualangan.

Yang kedua, teks dalam bentuk efek italic atau huruf miring. Di dalam novel petualangan simbolog Robert Langdon ini, puisi Dante dapat dipandang sebagai acuan moral salah satu karakter yaitu tokoh Dr. Zobrist. Karakter-karakter yang lain, termasuk Robert Langdon sendiri, berusaha menyelusuri jejaknya. Kebanyakan berupa gumaman, dan kenangan diutarakan dalam tulisan miring, sebagian yang lain tidak. Tulisan miring, atau gumaman ini pula sebagian diambil dari kutipan puisi Dante, mengingat The Divine Comedy merupakan inspirator dari tokoh psychopat Zobrist. Pada prolog tertulis:

\section{I am the Shade}

Through the dolent city, I flee.

Through the eternal woe (Brown, 2013: 5)

[Akulah sang Arwah

Melintasi kota muram, aku pergi

Melintasi kedukaan abadi, aku berlari]

Prolog novel Inferno menceritakan upaya terakhir Dr.Zobrist dalam menjalankan ide besarnya. Dia dihantui ketakutan karena dikejar-kejar oleh orang-orang yang menghentikan langkahnya. Dia naik ke puncak menara Badia lalu menjatuhkan dirinya ke tanah. Selama perjalanan itu, dia banyak mengeluarkan kalimat-kalimat 
yang seakan-akan dia sedang menghadapi suatu peristiwa yang menyerupai peristiwa yang dialami tokoh idolanya Dante Alighieri.

Tiga kalimat di atas merupakan pembuka dari novel Inferno. Tiga kalimat ini pula diambil secara terpisah dari puisi The Divine Comedy jilid Inferno Canto 1. Kalimat I am the Shade, diambil dari salah satu baris yang menceritakan Virgil memperkenalkan dirinya di hadapan penyair.

He answered: "Now I am the Shade, man once I was, (Inferno 1: 7)

[Ia menjawab: saat ini aku adalah Arwah, dahulu aku juga seorang manusia,...]

Pada kalimat-kalimat selanjutnya juga demikian. Dolent city dan eternal woe merupakan gambaran umum di canto awal puisi Inferno. Dolent city bisa saja dimaknai sebagai gloomy wood baris kedua canto 1 jilid Inferno

\section{I found me in a gloomy wood (Inferno 1: 5)}

Gloomy wood adalah suatu abstraksi adanya keterasingan penyair atas perubahan drastis konstruksi moral kota kelahirannya. Dikaitkan dengan novel Inferno, Kesamaan situasi ini juga dirasakan oleh Dr. Zobrist. Ia mengiyakan bait-bait puisi Dante yang mengagumkan tersebut. Pengarang menunjukkan kepiawaiannya menjelaskan makna tiap-tiap bait puisi Dante dengan menciptakan tokoh yang memiliki kegalauan yang sama dengan Dante.

Tokoh Zobrist adalah tokoh yang mengasingkan diri karena dituduh bioteroris oleh sesama profesinya. Ilmuwan di bidang rekayasa genetika ini pun bergerak di bawah tanah, melanjutkan penelitiannya tanpa pengawasan pihak 
WHO. Meskipun bermaksud mulia, Zobrist dianggap telah melakukan tindakan yang berbahaya tanpa koordinasi pihak siapapun. Yang membuat pihak WHO mencurigai proyek Zobrist adalah sumber dana proyeknya tersebut berasal dari Negara-negara penentang Amerika seperti Rusia, dan negara-negara Timur tengah yang tidak senang dengan kebijakan luar negeri USA. Kondisi yang sama juga dialami Dante sehingga ia diusir dari tanah kelahirannya.

Pada teks selajutnya, masih di halaman yang sama.

Here all hesitation must be left here (Brown, 2013: 5) [di sini segala keraguan harus ditinggalkan]

Pernyataan ambisius ini ditulis dalam efek miring. Kalimat di atas merujuk pada puisi Dante Inferno canto 3.

Here thou must all distrust behind thee leave (Inferno 3: 13)

[Di sini engkau harus menyingkirkan segala bentuk keraguan di belakangmu]

Kalimat ini semata-mata hanya sebuah ungkapan perasaan Dr. Zobrist untuk menunjukkan dirinya memiliki keteguhan yang sama dengan Dante dalam menghadapi masalah.

Kalimat yang dicetak miring selanjutnya adalah kalimat misterius yang tertulis di salah satu panji dalam mural Vasari di Palazzo Vacchio berjudul Battle of Marciano. Kalimat itu dalam Bahasa Itali adalah Cerca Trova dan dalam Bahasa Inggris berarti:

Seek and ye shall find (Brown: 9) [Carilah dan temukan] 
Kalimat ini diulang hingga sembilan belas kali dalam novel Inferno, yakni pada halaman 9 sebanyak dua kali, tiga kali halaman 108; halaman 10; halaman 12; halaman 29; halaman 92; halaman 109; halaman 114; halaman 115; halaman 116; halaman 127; halaman 152, halaman 253; halaman 270; Halaman 273; dan halaman 296; masing-masing satu kali. Kalimat ini, dalam Inferno, merupakan kata kunci dan juga motivasi dalam memecahkan tempat penyimpanan death mask Dante Alighieri virus Inferno yang akan disebarkan oleh Dr Zobrist. Kalimat ini beberapa kali muncul dan diikuti dengan kalimat time is running out.

Dalam catatan kaki Elliot (1995: 8) memaparkan maksud dari who invoke a second death [yang meminta kematian kedua] pada puisi Inferno canto 1 puisi Dante berasal dari Bahasa al-kitab.

And in these days men shall seek death, and shall not find it; and shall desire to die, and death shall desire to die, and death shall flee from them. (revelation; ix. 6) [dan pada saat-saat ini manusia akan mencari kematian, dan tidak akan menemukannya, dan akan berkeinginan untuk mati, dan kematian akan menjauh dari mereka].

Ayat di atas menjelaskan bahwa arwah-arwah yang berada di alam akhirat akan hidup abadi di dalamnya. Tidak ada kematian yang disebabkan oleh siksaan pedih di neraka. Jika dikaitkan dengan lukisan Battle of Marciano, lukisan ini merekam perang memperebutkan Florence. Florence, sejak masa Dante berstatus exile, telah diduduki oleh rezim yang otoriter. Hal ini menyebabkan kota-kota dan negara di luar Florence berusaha menaklukkannya. Setelah Henry VIII of German gagal dalam penyerangan ke Florence yang didokumentasikan Dante dalam Paradiso, tidak ada lagi raja yang berani menaklukkan Florence. Dante dalam bait-bait puisinya selalu mengharapkan ada kekuatan yang sanggup mengalahkan 
kekuasaan Florence, yang menurutnya dipimpin oleh raja yang zalim. Battle of Marciano merupakan awal kemenangan dinasti Medici di kota Florence dan juga mimpi Dante sewaktu ia masih hidup.

Isyarat Vasari yang tersirat melalui panji misterius yang tertulis Cerca Trova (carilah dan temukan) adalah kalimat terkait kematian. Kematian kedua yang dirindukan para penghuni neraka yang diceritakan Dante dalam Inferno berhubungan dengan peperangan yang memudahkan para pelaku peperangan untuk meregang nyawa mereka. Kedua simbolisme, antara teriakan penghuni neraka untuk segera dimatikan dan pelaku perang Marciano yang mengorbankan nyawa mereka, adalah dua keinginan yang sama dengan konsekuensi yang berbeda. Yang pertama mereka tidak akan menemukan apa yang mereka cari, yaitu kematian (kedua); dan yang lainnya mereka menemukan apa yang mereka cari, yaitu kematian. Jika diproyeksikan kembali ke dalam novel Inferno, kalimat ini tidak berarti apa-apa dalam puisi Dante selain untuk mengaskan bahwa apa yang menjadi puzzle masalah dalam novel ini harus segera dipecahkan.

Pernyataan dalam cetak miring juga ditemukan saat Langdon membayangkan keganjilan di dalam lukisan rekaan dari La Mappa Inferno karya Boticelli yang menggambarkan visi dunia bawah Dante.

The half-buried sinner with their legs in the air (Brown, 2013; 91) [para pendosa yang setengah-terkubur dengan kaki terjulur di udara].

Kalimat ini merujuk pada neraka Dante tingkat Sembilan di sumur ke tiga. Neraka ini dutujukan pada para penerima suap. Dikisahkan neraka ini diperuntukkan bagi musuh politik Dante di gereja yaitu Paus Boniface VIII, paus yang memfatwakan 
penjual-beliansurat pengakuan dosa. Mereka yang berada di neraka tersebut dihukum dengan tubuh yang tertancap di tanah sehingga kaki mereka tampak bergerak-gerak di atas.

... From out the mouth

Of every one emerged a sinner's feet,

And of the legs high upward as the calf. (Inferno 19: 77)

[Dari luar, mulut masing-masing muncul dari kaki-kaki pendosa, dan kaki-kaki mereka menjulang setinggi seekor sapi]

Dr. Sinskey dalam diamnya juga bergumam mengenai Dr. Zobrist dengan teks yang dicetak miring. He committed suicide.. (Brown, 2013: 222) [ia lebih memilih untuk bunuh diri] kalimat ini merujuk pada kisah Piero delle Vigno dalam Inferno canto 13 yang memilih bunuh diri karena didesak untuk menyembunyikan kecurangan yang dilakukan pejabat-pejabat istana terhadap Kaisar Frederick. Kutipan Homer di dalam pembuka ceritanya Odyssey juga diangkat dalam cetak miring Sing in me, Muse, and through me tell the story (Brown, 2013: 226) [Bernyanyilah di dalam diriku, Muse, dan ungkapkan cerita itu melalui diriku...]. Kutipan ini beberapa kali diparafraekan Dante dalam beberapa kesempatan. Salah satunya ada di Inferno canto 2

O Muses! O high genius! Now vouchsafe your aid... (Inferno 2: 9, 2013) [Wahai, muses! Wahai, engkau yang memiliki kecerdasan tinggi! Saat ini bantulah aku...]

Dari dua contoh ini, dan contoh-contoh sebelumnya dapat disimpulkan bahwa potongan-potongan teks The Divine Comedy yang digunakan dalam novel Inferno dengan efek cetak miring hanya memberikan suatu konfirmasi adanya kesamaan situasi dengan pengalaman yang terdapat di dalam hipogram. 
Jika diperhatikan secara seksama, dua jenis penulisan yang dipaparkan di atas, yaitu teks hipogram yang ditulis dengan huruf kapital atau bait-bait yang terpisah dan teks yang ditulis dengan cetak miring, tidak lebih merupakan atraksi tekstual pengarang novel Inferno untuk menunjukkan kepiawaiannya dalam mengkolaborasikan teks The Divine Comedy dan rangkaian cerita yang masingmasing terkait satu dengan yang lain. Ini juga dapat menunjukkan bahwa pengarang novel Inferno menguasai kedalaman teks hipogram yang tidak diketahui kebanyakan orang awam. Adapun pernyataan dalam novel ini diklaim berasal dari Commedia.

Shaking, Elizabeth unfolded he paper and read the handwritten note. It was a famous quote derived from the work of Dante Alighieri.

The darkest place in hell

Are reserved for those

Who maintain their neutrality

In times of moral crisis. (Brown, 2013: 163) [dengan tangan yang bergetar, Elizabeth membuka lipatan kertas itu dan membaca pesan tulisan-tangan di sana. Itu kutipan terkenal yang diambil dari karya Dante Alighieri.

Tempat tergelap di neraka

Dicadangkan bagi mereka

yang tetap bersikap netral

di saat krisis moral]

Pernyataan ini secara eksplisit tidak pernah hadir di dalam teks Dante. Namun, kutipan ini muncul tiga kali di dalam novel, yaitu pada epikgraf, epilog, dan halaman 163. pernyataan tersebut dapat disangkal bahwa kutipan ini berasal dari Dante. Jika merujuk pada tabel 2.9 tentang urutan akhirat versi Commedia, neraka 
terdalam, yaitu Judecca, diperuntukkan bagi mereka yang melakukan dosa-dosa penghianatan, dimana penghuninya adalah Judas, Brutus, dan Cassius

Dengan nada yang hampir serupa, idiom "the darkest place in hell are reserved for those who maintain their neutrality in times of moral crisis" pertama kali dipopulerkan oleh mantan Presiden U.S John. F. Kennedy. Mengingat ini adalah bahasa politik, Kennedy sebagai seorang politisi membaca Dante tentunya dengan menggunakan kacamata politik. Karena ini dipopulerkan kembali oleh Dan Brown, maka kutipan ini barang tentu adalah bukan kutipan yang keliru. Jika ditelusuri lebih dalam, maka sangat mungkin kutipan dahsyat ini merupakan turunan dari dialog dante dan Virgil ketika mengawali langkahnya di dalam neraka.

He thus to me: "This miserable fate

Suffer the wretched souls of those, who lived

Without or praise or blame, with that ill band

Of angels mix'd, who nor rebellious proved,

Nor yet were true to God, but for themselves..." (Inferno 3: 14)

[Ia lalu menjawab pertanyaanku: "Keadaan menyedihkan yang diderita jiwa-jiwa malang di tempat ini adalah mereka yang hidup tanpa berbuat kebajikan atau melakukan kejahatan, yang bercampur dengan nyanyian kepedihan dari malaikat-malaikat yang tidak melawan kuasa Tuhan dan tidak pula menaati-Nya, kecuali untuk diri mereka sendiri...]

Potongan teks di atas sangat mungkin merupakan rujukan awal kutipan yang dipopulerkan oleh novel Inferno ini. Dijelaskan bahwa konsekuensi jiwa-jiwa yang netral adalah terkatung-katung dalam ketiadaan siksaan dan ketiadaan Rahmat dari Tuhan. Dilanjutkan dalam potongan puisi selanjutnya. 
From his bound Heaven drove them forth

Not to impair his lustre; nor the depth

Of Hell receive them, ... (Inferno 3: 14)

[Dari (keadaan)-nya (yang demikian) Surga yang tergantung di langit sana mengusir mereka karena (dengan menerimanya) dapat merusak kilaunya, dan tidak pula neraka di bawah sana menerimanya]

Jiwa-jiwa netral ini, jika merujuk pada kutipan di atas, tidak menemukan tempat di alam akhirat. Oleh karena itu, seorang netral akan berada di alam antara. Alam antara ini bukanlah alam Purgatory karena alam ini adalah alam sementara. Yang dimaksud sementara di sini adalah alam dimana jiwa-jiwa yang berada di alam ini bergerak dari kaki gunung menuju puncaknya lalu berangkat menuju Paradiso. Alam bagi orang-orang netral ini adalah alam yang abadi bukan di alam sementara. Dalam pada itu, tempat yang berada di tengah yang bukan di Surga adalah batas antara alam Purgatory dan neraka, tentunya neraka terdalam.

\subsubsection{Persinggungan secara Simbolik}

Selain persinggungan berupa teks, persinggungan simbolik antara novel Inferno dan The Divine Comedy juga tersebar di dalam novel Inferno. Dari persinggungan ini akan tampak penyebaran simbol-simbol Commedia yang hirarkis di dalam novel Inferno. Persinggungan secara simbolik meliputi karyakarya seni yang merepresentasikan The Divine Comedy, tokoh-tokoh, dan simbolsimbol universal yang terkait dengan The Divine Comedy di dalam novel Inferno.

1. Dante; Peziarah, pengarang, dan karakter utama dalam perjalanan The Divine Comedy. Dalam Novel Inferno, ia adalah sosok inspirasi Betrand Zobrist. 
2. Virgil; dalam Inferno canto I Virgil sudah memperkenalkan dirinya di hadapan Dante dan mendampingi Dante hingga di Earhtly Paradise, lalu digantikan olrh Beatrice. Guide me, dear Virgil, across the void (Inferno: 6, 2013) [Bimbinglah aku, wahai Virgil, melintasi kehampaan]

3. Beatrice; dalam Commedia, nama Beatrice sering disebut. Ia adalah tokoh motivasi bagi Dante untuk untuk menjalani misi penjelajahannya

4. Matilda; tokoh wanita cantik bercadar yang ditemui Dante di Earthly Paradise ini, meskipun tidak disebut namanya, hadir secara simbolik di dalam teks novel Inferno dalam karakteristik. A veiled woman (Brown, 2013: 10) [perempuan bercadar]

5. The Mendacium; Dewa tipuan dalam mitologi Romawi, dalam neraka Dante ia berada di city of Dis. Dalam Inferno, Mendecium adalah nama sebuah perusahaan yang bergerak di bidang jasa ilusionisme, atau pembuat kejadian-kejadian palsu.

6. Venus; Dalam Commedia, Venus adalah bintang yang mampu memberikan pengaruh birahi terhadap manusia di bumi. Venus berasal dari nama Dewi dari mitologi Romawi. Di dalam Inferno, lukisan-lukisan Boticelli yang terkait dengan dewi kecantikan ini sering dibicarakan dan ditemui Robert Langdon.

7. David; David adalah salah satu nabi yang ditemui Dante di surga rasi bintang. David adalah karya patung Boticelli yang paling dikagumi Robert Langdon. Dalam satu kesempatan dia bergumam I'm leaving Florence 
without visiting the David (Brown, 2013: 265) [Aku meninggalkan Florence tanpa mengunjungi David]

8. Le Maschere; simbol umum untuk drama, berupa dua topeng yang menyimbolkan tragedy dan comedy. Simbol ini mengingatkan bahwa karya Dante yang popular dikenal dengan nama Commedia, atau cerita komedi. Dalam Inferno halaman 37, Langdon memperhatikan lambang ini di sebuah sampul buklet drama Sienna.

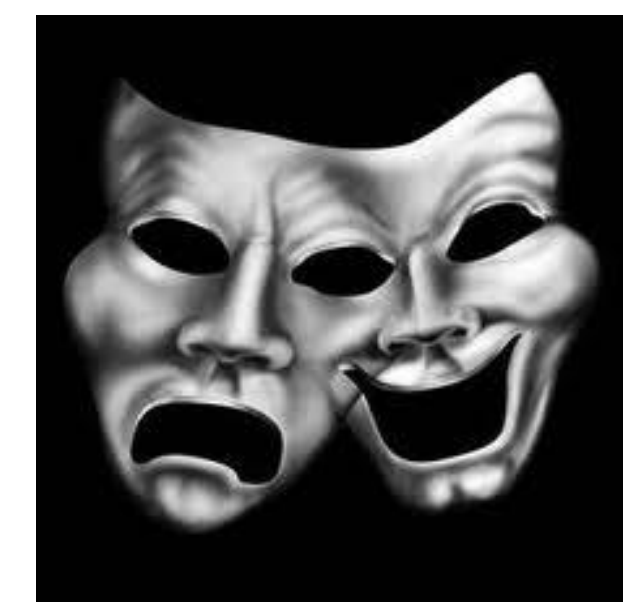

Gambar 3.1 Lambang Tragedi dan Komedi biasanya disinonimkan dengan pertunjukan drama

9. Icon Lucifer ala Dow Chemical; Lucifer adalah raja di negeri keputusasaan (neraka) Dante. Simbol ini dipadanankan dengan simbol biohazard di novel Inferno.

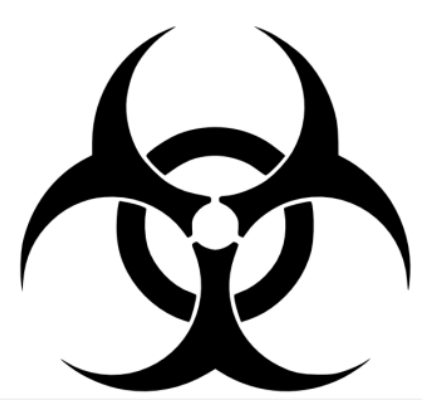


Gambar 3.2 Lambang Biohazard Diangkat dari Penyimbolan Lucifer yang Memiliki Tiga Kepala

10. The Three of Shades; patung karya Rodin ini merupakan ilustrasi dari inskripsi di gerbang masuk neraka Dante. Novel Inferno memunculkan lukisan ini pada saat Robert Langdon membawa kuliah mengenai karyakarya yang terinspirasi dari The Divine Comedy.

11. The Gates of hell; s.d.a.

12. Phlegyas; iblis penjaga sungai Styx. Dalam Inferno, Langdon memaparkan lukisan Stradanus yang memvisualisasikan neraka Dante. dalam Lukisan itu sosok Phlegyas tengah mengatar Dante dan Virgil menyusuri sungai Styx.

13. Charon; Iblis tukang perahu di sungai Acheron. Sosok ini adalah iblis pertama yang ditemui Dante setelah memasuki gerbang neraka. Konon berdasarkan mitologi Yunani dan Romawi, Charon akan mengantar arwah yang sudah mati ke alam akhirat jika arwah itu memberinya koin emas. Itu sebabnya setiap ritual kematian mayat yang akan dikremasi diberi dua koin yang diletakkan di masing-masing matanya. Satu untuk Charon dan yang satunya lagi untuk Phlegyas. Robert Langdon, dalam novel Inferno, menjelaskan tokoh ini di sebuah kuliah umum.

14. Geryon; Dante, saat menuju ke Malebogne, menyempatkan dirinya mengendarai monster ini. Geryon merupakan makhluk dengan kepala seperti manusia dan tubuh yang sangat besar. Di punggungnya ditemukan sayap yang lebar, sehingga ia bisa terbang dari satu bukit ke bukit yang 
lain. Langdon, dalam Inferno, mengingat-ingat kembali dirinya saat membawakan ceramah mengenai monster-monster neraka Dante, salah satunya Geryon.

15. Pieta; Patung karya Boticelli ini adalah visualisasi pengalaman Dante di Empyrean. Dante melihat Jesus yang terbaring di pangkuan Virgin Mary. Langdon dalam novel Inferno menyaksikan secara visual lukisan itu di dinding gereja tempat pembaptisan Dante.

16. Ponte Vecchio; Nama sebuah jembatan di atas sungai Arno di Florence. Dante menceritakan bahwa jembatan tersebut adalah saksi pertumpahan darah dua faksi politik yang disebabkan oleh cinta yang terlarang. Sienna sempat melintasi jembatan ini. Langdon menceritakan kejadian berdarah yang disesalkan oleh Dante.

17. Neptunus; Dewa tertinggi dalam mitologi Romawi. Di Yunani ia bernama Poseidon. Tokoh ini disebutkan dalam satu analogi Dante saat ia kesulitan merekam keindahan peristiwa di surga tertinggi. Ia menganalogikan dirinya seperti Argonaut yang terperangah menyaksikan peristiwa kelahiran Neptunus. Argonaut tidak bisa berbuat apa-apa kecuali mempertahankan peristiwa tersebut ke dalam memorinya dan menjauhkan kelupaannya tentang peristiwa tersebut. Dalam novel Inferno, Sienna dan Langdon menemukan beberapa patung Neptunus di Palazzo Vecchio karya-karya tokoh ternama di masa Ranaissance.

18. Boundelmonte; pemuda Florence yang menjalin cinta terlarang. Ia menghianati pertunangan politik yang dibuat oleh keluarganya. Pada 
akhirnya, ia dibunuh oleh faksi dari calon mertuanya, yang menyebabkan terjadinya pertumpahan darah dari dua faksi terkuat di Florence. Dante dalam Commedia mengabadikannya dengan bahasa penyesalan, bahwa peristiwa tersebut telah memantik perpecahan di Florence hingga berabadabad. Dalam novel Inferno, Langdon membacakan inskripsi di jembatan Ponte Vecchio yang mengabadikan peristiwa Bondelmonte dengan mengutip potongan puisi The Divine Comedy Dante.

19. Hercules; Keturunan dewa Jupiter dalam mitologi Romawi ini dikenal sebagai tokoh yang tangguh, heroik dan suka menolong manusia. Dalam perjalanan hidupnya dia banyak membunuh monster-monster kejam dari dunia bawah. Virgil banyak bercerita tentang tokoh ini kepada Dante. Robert Langdon memperkenalkan Sienna patung yang mengabadikan kisah penaklukan Cacus oleh Hercules. Vayentha, dan sepasang tokoh dalam novel Inferno ini di kesempatan yang hampir sama memiliki komentar yang miris setelah menyaksikan patung Hercules and Diomedes.

20. Cacus; Tokoh motologi Romawi yang merupakan anak dari Medusa ini adalah penjaga parit neraka ke tujuh di neraka Maleboge, tempat para pencuri disiksa. Dalam The Divine Comedy, Cacus dikenal dengan nama Centaur. Virgil menceritakan kepada Dante bahwa dengan sekali tinju oleh Hercules, Cacus terkapar mati karena ia telah mencuri barang-barang milik Hercules saat Hercules sedang tidak ada di rumah. (selanjutnya, baca no.19, Hercules). 
21. Diomedes; Orang terhormat di Yunani kuno ini adalah anak dari Tydeus, raja Argos. Ia bekerjasama dengan Ulyssess dalam ekspedisi menaklukkan Troy. Dante menemukan tokoh ini di dalam parit ke delapan neraka Malebolge. Dalam The Divine Comedy, Virgil menjadi juru bicara Dante untuk berdialog dengan Diomedes disebabkan Dante adalah seorang Romawi yang mempunyai tutur bahasa yang kasar di mata orang-orang Yunani, sedangkan Diomedes adalah seorang pangeran Yunani terhormat. Virgil takut Dante hanya akan melecehkan Diomedes. (Selanjutnya, baca no.19 Hercules).

22. Icarus; dia adalah tokoh mitologi Yunani dan Romawi. Ia anak dari Daedulus yang memiliki sayap dari lilin. Dengan sayap lilinnya itu dia terbang tinggi menuju matahari. Ketika mendekati matahari, sayapnya meleleh dan ia terjatuh di laut Icaria. Namanya pun diabadikan sesuai nama laut tempat ia jatuh. Dante membandingkan pengalaman berbahayanya di Inferno Canto 17. Ia menaiki pundak Geryon dan kehilangan kendali atas dirinya seperti Icarus yang lepas kontrol terhadap ambisinya saat ia terbang menuju matahari. Langdon dan Sienna dalam Inferno melintasi Hall of the Five Hundred karya Vasari dan menemukan salah satu muralnya yang berjudul The Fall of Icarus.

23. Ciccaguida; Nenek moyang Dante. Dalam Paradiso, diceritakan Dante bertemu dengan kakek moyangnya di surga Mars, surga para pejuang salib. Dalam dialog mereka Dant mendapat dukungan yang besar dari moyangnya tersebut atas perjuangannya selama ini. Novel Inferno tidak 
menyebut secara langsung mengenai tokoh ini tetapi potongan puisi Paradiso canto 17 yang digunakan Langdon. Kalimat dipakai Langdon untuk mempertegas bahwa Dante sangat merindukan Florence di masamasa pengasingannya. Kalimat tersebut berasal dari dialog Dante dan

\section{Ciccaguida dalam Commedia.}

24. The Rape of Sabine; patung karya Giombologna ini adalah simbol tragis yang mengawali kejayaan kerajaan Roma di bawah kepemimpinan Romulus. Diceritakan orang-orang Sabine tidak menginginkan adanya pernikahan perempuan-perempuan mereka dengan orang-orang Roma yang pada waktu hanya sebuah kerajaan kecil. Hal ini disebabkan Romulus menginginkan adanya pernikahan politis antara lelaki-lelaki mereka dengan perempuan-perempuan Sabine sebagai strategi menaklukkan Sabine tanpa perang. Pemimpin Sabine menolaknya. Oleh karena itu, Romulus melakukan tipu muslihat dengan mengadakan perayaan memperingati dewa Neptunus dan mengundang masyarakat Sabine. Dengan cara seperti itu para ksatria Roma dengan leluasa melakukan pemaksaan dan pemerkosaan terhadap perempuan-perempuan Sabine. Orang-orang Sabine setelah peristiwa itu harus merelakan perempuan-perempuan mereka untuk diperistri oleh lelaki-lelaki Roma, yang secara otomatis telah menaklukkan wilayah Sabine. Junstanian, di Paradiso canto 6, menceritakan kepada Dante kehebatan pendahulupendahulu Roma dalam mencapai kejayaannya di antaranya kehebatan Romulus menginstruksikan pemerkosaan perempuan-perempuan Sabine, 
dan Julius Caesar menaklukkan kerajaan mesir dengan menggaet Cleopatra. Rape of Sabine adalah patung yang berdiri di luar ruangan Loggia dei Lanzi. Vayentha, sebelumnya Sienna dan Langdon dalam novel Inferno, memandangi dengan miris patung-patung yang menonjolkan penyiksaan terhadap perempuan dan tingkah laki-laki yang di luar kebiasaan umum. Patung-patung tersebut adalah The Rape of the Sabine, The Rape of Polyxena, Perseus Holding the severed Head of Medusa, dan Hercules and Diomedes.

25. The Rape of Polyxena; Polyxena merupakan anak gadis dari raja Priam kerajaan Troy. Ia menjadi budak dari Achilles. Sebelum meninggal, Achilles menginginkan Polyxena mengorbankan nyawanya untuk menemani arwahnya di alam akhirat. Dalam beberapa kesempatan, Achilles membuktikan dirinya adalah pelindung bagi Polyxena saat di kamp Yunani maupun di wilayah Troy yang ditaklukkan. Dalam nerakanya Dante melihat Polyxena dan Achilles dihempas angin yang kencang. (selanjutnya baca no.24 untuk novel Inferno).

26. Perseus Holding the Severed Medusa; Patung karya Benvonito Cellini ini mengabadikan kisah ksatria bernama Perseus yang berhasil menaklukkan Medusa dengan memenggal kepala ular berkepala manusia tersebut. Dante membicarakan hal ini untuk mengilustrasikan sifat keras kepala arwaharwah yang berdosa di neraka. (selanjutnya baca no. 24 untuk novel Inferno). 
27. Hercules and Diomedes; Pertarungan dua tokoh ini diabadikan dalam patung karya Vincenzo de' Rozzi. Pertarungan kedua tokoh ini tidak ditemukan secara eksplisit di dalam The Divine Comedy. (selanjutnya, baca no. 19, 21, dan 24 untuk novel Inferno).

28. Jupiter; dalam mitologi Yunani dewa ini bernama dewa Zeus. Jupiter dikenal sebagai dewa petir. Ia adalah anak dari Dewa Neptunus. Ia beberapa kali disebutkan dalam Commedia, terutama saat Virgil dalam Inferno canto 14 menceritakan bahwa Capaneus tewas akibat dirinya dengan angkuh melawan Jupiter dengan memanjati dinding untuk menyaingi ketinggian sang dewa. Cerita ini adalah contoh dosa takabur di neraka kekerasan. Dalam novel Inferno, Langdon memperhatikan konstruksi rangka bangunan atap di ruang rahasia di Palazzo Vecchio bernama Jupiter's arrow point.

29. Odyssey; dalam bahasa latin dikenal dengan nama Ulysses. Panglima perang Yunani ini memimpin armada pasukan elit untuk menaklukkan Troy. Ia juga dikenal karena petualangan uniknya dalam perjalanan pulang pasca perang Troy. Odyssey bersama Diomedes menyapaVirgil dan Dante di neraka untuk para pemimpin yang menipu pengikutnya. Dalam novel Inferno, tokoh ini disebutkan ketika menyebutkan mahakarya Homer, Odyssey.

30. Homer; Homer adalah seorang penyair ternama sepanjang masa. Ia berasal dari Yunani. Mitologi-mitologi Yunani hingga saat ini dikenal dikarenakan karya-karyanya tersebut. Dante sempat menemui tokoh ini di 
neraka Limbo. Homer, dalam Inferno canto 4, bertukar syair dengan Virgil yang membuat Dante terkagum-kagum menyaksikan kejadin tersebut. Dalam novel Inferno, tokoh ini oleh Langdon sebagaimana Dante diakui kehebatannya terutama mengenai mantra yang diucapkan Homer di kalimat awal karyanya yang terkenal, Odyssey. "Sing in me, Muse, and through me tell the story..."

31. Muse; dewi pengetahuan dan seni. Bagi kebanyakan seniman di era Yunani kuno dan Romawi Kuno, dewi ini memberikan inspirasi ke dalam hati mereka. Dante dalam pembukaan puisinya di Inferno canto 2 memohon kepada Muse agar diberi pencerahan dalam melanjutkan puisinya. Dan Brown dalam karyanya, Novel Inferno, menyisipkan kalimat permohonan kepada dewi Muse pada halaman 226.

32. Springtime dan Birth of Venus; kedua lukisan ini adalah karya Boticelli yang dipajang di The Hall of Five Hundred. Kedua karya ini bertemakan dewi Venus yang memberikan keseimbangan dan menebarkan cinta. Venus adalah dewi cinta dan kecantikan. Dalam mitologi Yunani ia bernama Aprodite. Dante seringkali menyebut nama dewi ini, bahkan salah satu surganya ia beri nama sesuai nama dewi ini. Dr. Sinskey dalam Novel Inferno menyukai dua karya tersebut, karena memberikan kesan simbolik arti pentingnya nilai-nila kesuburan dalam setiap peradaban.

33. Erinyes; Nama ini dalam mitologi Romawi kawanan tiga monster betina bersaudara. Mereka dikelompokkan sebagai bagian dari makhluk bawah tanah yang digambarkan bertubuh manusia dengan tekstur yang keriput 
menyerupai nenek-nenek dengan kepala anjing. Badannya berwarna hitam dengan ular sebagai rambutnya. Tiga bersaudara ini kerap menyiksa manusia yang berbuat jahat, hingga mereka mati. Mereka adalah Tisifon, Alecto, Megaira. Tiga tokoh ini disimbolkan Dante sebagai makhlukmakhluk yang melambangkan penyesalan. Ini dapat ditemui dalam Inferno canto 9, ketika Dante melintasi City of Dis. Ia melihat tiga sosok Erinyes yang berdiri di hadapannya dengan menyebut mereka sebagai three hellish furies. Dalam novel Inferno, Untuk memecahkan teka-teki puisi berbentuk spiral tersebut, Langdong melihat kata Chthonic. Iapun memaparkan bahwa kata ini menyimbolkan makhluk-makhluk mitologi Romawi yang termasuk ke dalam golongan makhluk dunia bawah. Langdon menyebutkan beberapa makhluk dunia bawah, yaitu Erinyes, Hekete, dan Medusa.

34. Medusa; ratu dari dunia bawah ini adalah wanita berwujud ular yang sangat besar dengan kepala seorang wanita yang cantik. Helai-helai rambutnya adalah ular-ular kecil yang berbisa. Matanya memiliki kekuatan khusus. Siapapun yang menatapnya akan berubah menjadi batu. Dante melambangkan tokoh mitologi ini sebagai monster keputusasaan. (selanjutnya baca no. 24, dan 26). Novel Inferno memunculkan beberapa kali simbol Medusa. Tokoh yang memproduksi lambang ini adalah dr. Zobrist. Dia bukan hanya menciptakan clue dengan menggunakan tokoh ini, tetapi juga mengidentikkan Medusa secara metaforik dengan dr Sinskey. Zobrist menyebutnya sebagai 'the silver-haired devil'. 
35. Jesus; Tokoh suci umat Kristen di seluruh dunia. Sebagai anak Tuhan, Ia dalam doktrin agama Kristen secara singkat melakukan sacrament untuk menyelamatkan umat manusia dan sekaligus membuka pintu surga bagi pengikutnya. Dante dalam Commedia menyaksikan Jesus berbaring di pangkuan Perawan Maria di atas surga Empyrean, puncak surga Dante. Novel Inferno menyebut Sang Nabi ini beberapa kali. Yang pertama, tokoh ini disebut dalam orasi Zobrist. Zobrist merekam orasinya dalam sebuah video berdurasi sepuluh menit. Ia mengatakan bahwa ia tidak takut dengan kematian atas resiko dari upayanya menyebarkan virus Inferno. Ia melanjutkan bahwa Jesus, Socrates, dan Martin Luther King telah membuat gagasan mulia dengan rela mengorbankan nyawa mereka. Yang kedua, ketika rombongan dr Sinskey memasuki museum Hagia Sophia. Bruder, pengawal Sinskey terkejut melihat kemegahan interior Sophia yang sangat berkelas. Ia spontan mengucapkan "Jesus” yang ketiga, simbol suci Cross yang bersandar di dinding Hagia Sophia yang melambangkan pengorbanan Yesus. Yang terakhir, lukisan berjudul Pieta (lihat no.15).

36. Socrates; Bapak para filsafat Yunani ini adalah seorang pemikir yang kontroversial di masanya. Ia harus meregang nyawa akibat pemikirannya yang gila. Ia dihukum mati oleh penduduk Athena dengan meminum racun karena ia telah dianggap racun bagi generasi muda. Pemikiranpemikirannya tidak secara langsung bisa dinikmati hingga sat ini karena Ia sama sekali tidak menuliskan pemikirannya. Pemikirannya diabadikan 
oleh muridnya Plato. Plato menuliskan pemikiran-pemikiran Socrates melalui tulisan-tulisannya. Salah satu bentuk penghargaan Dante, ia memasukkan Socrates ke dalam kerajaan neraka Limbo. Dante menyaksikan tokoh-tokoh seperti Plato, Democritus, Diogenes, Heraclitus, Empedocles, Anaxagoras, Thales, Zeno, dan Dioscorides mengelilingi Socrates yang tengah berceramah. (lihat gambar 2.1).

37. Dr. Ferris, lelaki beruam; secara implisit tokoh ini menyerupai sosok Adamo of Brescia yang ditemui Dante dalam The Divine Comedy. Adamo atau Master Adam adalah tokoh, menurut Dante, yang semasa hidup menipu rakyat Florence dengan membuat koin/uang palsu. Diceritakan dia seorang ahli kimia yang mampu membuat emas sepuhan. Dari kemampuannya itu, ia memperkaya dirinya dengan membuat emas/uang palsu dari bahan yang murah. Konsekuensinya, di neraka Dante ia disiksa dengan penyakit yang membuat tubuhnya menjadi gatal dan bernanah hingga wajah dan tubuhnya rusak oleh garuk dan nanah. Pengarang novel Inferno mencoba memunculkan sosok Adamo dengan menciptakan seorang penipu ulung bernama dr. Ferris untuk mengelabuhi Langdon dan menjalankan pekerjaannya bersama Sienna. Ia memiliki identitas ganda yaitu sebagai dr. Marconi saat di rumah sakit dan menjadi dr Ferris saat di gereja Museo Casa di Dante. Konsekuensi dari kecerobohan dan kebohongannya menjadi Dr. Marconi, dan juga berpura-pura mati akibat ditembak oleh Vayentha di rumah sakit, yang merupakan skenario Provos, wajah dan dadanya menjadi merah dan bernanah. Keduanya juga 
menemani tokoh sentral menemukan apa yang dicari sang tokoh. Adamo menemani Dante untuk mengidentifikasi nama-nama yang mungkin Dante kenal, sedangkan dr. Ferris menemani Dante ke Venesia untuk memecahkan rahasia di balik puisi Zobrist. Kemiripan yang lainnya adalah keduanya berakhir dengan permusuhan antar sesama penipu. Adamo bercekcok dengan Sinon pembuat patung kuda raksasa yang mengelabuhi tentara Troy, sedangkan Ferris bercekcok dengan Sienna yang juga sedang menjalankan ilusi terror terhadap Dante. Perbedaan kedua tokoh ini adalah penyakit yang diderita Ferris dijelaskan secara ilmiah bukanlah dari hukuman atas dosa kebohongannya seperti yang dialami Adamo.

38. St. Lucia; tokoh wanita suci ini dahulu adalah seorang putri dari Venesia yang cantik jelita dan taat. Kecantikannya yang mempesona membuat banyak lelaki mencoba untuk menaklukkan hatinya. St Lucia tidak ingin menyakiti hati pria-pria tersebut dan juga tidak ingin hubungan serius pernikahan hanya akan menjauhkan dirinya dari Tuhan. Oleh karena itu, ia memutuskan untuk mencungkil kedua matanya. Sejak saat itu tidak ada pria yang mau mendekatinya. Dante di dalam The Divine Comedy dikunjungi oleh Beatrice disebabkan puisinya telah membuat St Lucia di Empyrean bersedih. Karena kesedihannya itu, tatanan surga menjadi kacau. Dari kekacauannya itu, St Lucia meminta Beatrice untuk segera menemui Dante untuk menyampaikan kabar gembira dari langit. Langdon, Ferris dan Sienna terpaksa harus beranjak meninggalkan Florence ke Venesia untuk menemukan jejak St Lucia karena clue nya dijelaskan 
bahwa ada seorang duke yang mencungkil tulang belulang orang buta. Langdon berkesimpulan bahwa orang buta yang dimaksud adalah St. Lucia.

39. Gabriel; Gabriel the archangel adalah malaikat yang dalam doktrin Yudea-Kristiani yang mendapat perlakuan khusus dari Tuhan. Ia ditugaskan membisikkan pesan Ilahiyah kepada manusia-manusia pilihan. Gabriel. Dante dalam Commedia mengungkapkan bahwa ia beberapa kali bertemu dengan Gabriel terutama di Surga. Di Purgatory ia hanya bertemu sekali. Itupun dia melihat sosok Gabriel dalam bentuk patung di penyucian The Praud. Sosok Gabriel tampak sedang membuka gerbang surga untuk mempersilahkan Adam dan Eve ke bumi. Di dalam novel Inferno, Langdon memandang patung Gabriel berdiri di atap bangunan Santo Markus. Ia ingin mendeskripsikan bahwa bangunan Santa Markus dan pelatarannya adalah keajaiban megah dari sentuhan tangan manusia.

40. Muhammad, Mahomet; Tokoh yang diyakini bagi umat muslim sebagai pembawa pesan dari Allah swt. Ia menyebarkan ajaran baru pada abad ke7 yang disebut agama Islam, yang berpusat di Mekah. Ajarannya ini dibukukan dalam Alqur'an dan Hadist. Agama yang dibawakan Rasulullah beberapa abad setelah meninggal menjadi kekuatan politik dan dengan pengikut yang teramat besar. Dante menyebutnya dalam Inferno canto 28 sebagai pemimpin yang menyebarkan benih-benih pertikaian, oleh karena itu, konsekuensinya tokoh suci umat Islam ini disebet pedang oleh Iblis sehingga isi perutnya terburai. Mahomet juga mempertontonkan 
perut terbelahnya itu di hadapan Dante, Virgil, dan salah satu sahabat Muhammad Ali. dalam novel Inferno, nama Muhammad tiga kali disebut. Salah satunya Langdon memberikan penjelasan tradisi doktrin kedua agama Logosentrisme ini.

41. Apollo; anak dari Jupiter dan Latona. Dalam mitologi Romawi, Apollo adalah dewa matahari, pecinta musik, peramal, dewa kesembuhan dan seorang pemanah handal. Dalam The Divine Comedy, Dante didampingi Beatrice dan Apollo untuk berangkat menuju surga dari puncak penebusan. Apollo juga membagi pengalaman kepada Dante mengenai gerbang surga yang akan mereka tuju. Saat Langdon, Bruder dan Sinskey tiba di Istanbul, digambarkan mereka melintasi sisa-sisa peninggalan Romawi kuno dan peradaban sebelumnya, seperti kuil Apollo di Delphi, pilar Milion, obelix Mesir di Luxor.

42. Justanian; Raja Bizantium ini mencapai titik kejayaan Romawi yang terbesar dan yang terakhir. Ia memimpin Romawi Timur. Di masa pemerintahannya ia berhasil menaklukkan Romawi barat yang berpusat di Italia. Ia juga bersama armada perangnya berhasil menaklukkan pesisir Atlantik hingga ke wilayah Afrika barat dan Afrika utara. Salah satu peninggalannya adalah Hagia Sophia. Dalam Surga Mercurius, ia banyak membagi pengalaman pemerintahan dan politik kepada Dante. Justanian mengakui karena kesombongannya dalam memimpin Romawi ia tidak bisa naik ke surga yang lebih tinggi. Langdon menjelaskan lebih detail bahwa salah satu kesombongan yang ia beberkan dan diingat oleh sejarah 
ketika ia berhasil menyelesaikan pembangunan Hagia Sophia. Ia berkata "Solomon, I have outdone thee". Itulah alasan mengapa Dante menempatkan Justanian selamanya hanya berada di bawah Solomon king.

43. King Solomon; Raja Sulaiman adalah tokoh yang kisah-kisahnya tersebar di dalam kitab-kitab suci tiga agama langit. Ia dikenal sebagai raja yang yang sangat kaya dengan istana yang megah. Dante menempatkan King Solomon di surga keempat. Hal ini disebabkan Tuhan, St Aquinas bercerita, masuk ke dalam mimpi Solomon. Ia bersedia mengabulkan satu permintaan Raja Sulaiman. Dari kesempatan yang luar biasa itu raja Sulaiman tidak menginginkan apapun kecuali membedakan yang mana yang benar dan salah. Oleh karena itu di surga matahari King Solomon menjadi raja di surga tersebut. (selanjutnya baca no.42).

Setelah menjelaskan simbolisme berupa tokoh-tokoh yang berada di dalam Commedia secara eksplisit maupun implisit terdapat di dalam novel Inferno karya Dan Brown, dapat ditemukan adanya penyebaran beberapa tokoh atau lambang yang dapat mengacaukan hirarki yang dibangun oleh Dante dalam puisinya. Tokoh atau lambang yang paling menonjol didekonstruksi dalam novel Inferno adalah Muhammad (Mahomet) pada nomor (40). Tokoh ini, berdasarkan narasi novel Inferno, bersanding sejajar dengan lambang Cross yang merepresentasikan tokoh Jesus dalam doktrin Kristen.

Lambang selanjutnya adalah karya-karya yang merepresentasikan kejahatan legal yang merendahkan perempuan. Simbol nomor (24), (25), dan (26) adalah karya-karya agung yang menggambarkan kejayaan, dan penaklukan 
seorang raja. Di tempat yang lain, nomor (27) Hercules and Diomedes karya agung yang menggambarkan kekuatan dua lelaki tangguh yang saling bertarung dengan cara yang sulit dinikmati oleh perempuan. Teks novel Inferno menggunakan kacamata Vayentha yang merepresentasikan perempuan dalam menilai karya-karya agung dengan latar-belakang sejarah yang agung pula.

Pada sub-bab selanjutnya, akan dibahas mengenai dua point yang menjadi fokus dekonstruksi sebagaimana yang telah dijelaskan di atas.

\subsection{Diskursus Dekonstruksi dalam Novel Inferno}

Reinterpretasi Al-kitab ke dalam puisi Commedia telah menciptakan konstruksi hirarkis yang kokoh mengenai ruang eskatologi yang absurd. Konkretisasi akhirat ini bukan hanya menghadirkan tokoh-tokoh dan tindakan atau sikap yang secara sistematis dari yang mulia hingga yang paling hina, tetapi juga dapat memperlihatkan arogansi Dante dalam membunuh sikap dan tindakan tokoh tertentu. Hal ini menyebabkan tokoh dan sikap mereka dipandang tidak layak untuk berkembang di dalam peradaban yang religius.

Puisi Dante dari zaman ke zaman menjadi bacaan yang menarik bagi kebudayaan atau ideology tertentu, namun membuat geram kebudayaan atau ideologi yang lain, karena memunculkan oposisi hirarkis yang sangat jelas. Novel Inferno karya Dan Brown memperlihatkan trace dalam teks Commedia. Novel terakhir Dan Brown ini menghadirkan Konteks atas hirarki yang dibangun oleh Dante dalam puisinya. 


\subsubsection{Negosiasi Dua Mukjizat}

Jika merujuk pada data di bab awal yang mengatakan bahwa The Divine Comedy hingga saat ini menjadi bacaan populer dan telah diterjemahkan lebih dari tiga puluh bahasa, pertanyaan yang paling mendasar dari kepopuleran puisi ini adalah siapakah pembaca populer yang dimaksud, dan dari kalangan manakah puisi ini diminati. Tiga bulan setelah peluncuran Novel Inferno, pesanan puisi Commedia semakin berlipat berlipat. Meskipun tidak serta-merta dapat disimpulkan bahwa novel Inferno telah berhasil membuka ruang negosiasi di antara kalangan konservatif untuk menerima puisi ini, dengan kehadiran novel Inferno, pembaca di luar penganut agama kristiani setidaknya mampu memaklumi mengapa Dante menulis puisi yang seradikal ini.

Commedia sangat radikal dalam menghadirkan tokoh-tokoh yang mempunyai pengaruh terhadap zaman. Tokoh-tokoh yang memiliki pengikut di kalangan Kristen seperti Paus Banoface VIII, Paus Nicholas II, dan Paus Calestine $\mathrm{V}$ adalah tokoh-tokoh dimuliakan yang sekaligus menjadi contoh buruk dengan dijebloskannya mereka ke dalam neraka Dante. Dalam Commedia juga, Dante menyebutkan bahwa dia bertemu Frederick II disiksa sebagai seorang yang pembid'ah. Padahal apabila menilik sejarah, Frederick II adalah kaisar yang mampu memukul mundur pasukan Dinasti Abbasiyah saat perang memperebutkan Yerussalem.

Namun di antara nama-nama yang disebutkan di atas, Muhammad (Mahomet) adalah tokoh yang paling keras direndahkan oleh Dante. Muhammad 
menjadi tokoh dengan siksaan yang sangat berat di lembah Malebolge. Seperti yang dipaparkan sebelumnya, Mahomet mendapatkan siksaan dengan perut yang disabet pedang oleh iblis.

Whilst eagerly I fix on him my gaze,

He eyed me, with his hands laid his breast bare,

And cired, "Now mark how I do rip me: lo!

How is Mohammed mangled: before me

Walks Ali weeping, from the chin his face

Cleft to the forelock; and the other all,

Whom here thou seest, while they lived, did sow

Scandal and schism, and therefore thus are rent.

A fiend is here behind, who his sword

Hack us thus cruelly, silvering again

Each of this ream, when we have compast round

The dismal way; for first our gashes close

Ere we repass before him. But, say who

Art thou, that standest musing on the rock,

Haply so lingering to delay the pain

Sentenced upon the crimes." "Him death not yet,"

My guide rejoin'd, "Hath overta'en, nor sin

Conducts to torment; but, that he may make

Full trial of your state, I who an dead

Must through the depth of Hell, from orb to orb

Conducts him. Trust my words; for they are true."

More than a hundred spirits, when that they heard,

Stood in the foss mark me through amaze 
Forgetful of their pangs. "Thou, who perchance

Shalt shortly view the sun, the warning thou

Bear to Dolcino: bid him, if he wish not

Here soon to follow me, that with good store

Offood he arm him, lest imprisoning snows

Yield him a victim to Novara's power;

No easy conquest else": with foot unpraised

For stepping, spake Mohammed, on the ground

Then fix'd itu depart. (Inferno 28: 115-116,)

[Ketika mataku berusaha beradaptasi dengan kegelapan untuk memandang, Ia menatapku, dengan tangannya yang bersandar di dada telanjangnya dan berseru, "sekarang saksikanlah bagaimana aku merobek dadaku: hah! Bagaimana (seorang) Muhammad begitu terkoyak: di sebelahku Ali berjalan sambil menangis, wajahnya terbelah dari dagu hingga ke ubun-ubun; semua yang engkau lihat di sini, semasa hidupnya meninggalkan benih-benih dan pelaku perpecahan. Dan oleh karena itu, mereka harus membayarnya. Sesosok iblis berada di belakang, saat melintasinya dengan pedang ia menyabet kami dengan sadis, menebas setiap arwah yang ada di dalam rim ini. Saat kami berjalan mengelilingi setapak yang menyakitkan ini; sekali luka ini mengering iblis itu sudah berada di hadapan kami lagi. Tapi katakan siapa engkau, yang berdiri mengendap-endap di balik batu, janganjangan engkau berusaha menunda hukuman atas kejahatan yang engkau pernah perbuat." "ia belum mati" Pembimbingku menampik, "belum menyusul (engkau), tidak pula dosa membawanya pada siksaan; tapi ia belajar dari apa yang engkau sampaikan, Aku yang telah mati ini menuntunnya melalui kedalaman Neraka, dari satu lingkaran ke lingkaran yang lain, percayalah padaku; apa yang mereka katakan itu benar adanya." Lebih dari seratus jiwa, ketika mendengar (percakapan kami), terperangah memandangku di parit tempat mereka melintas, hingga mulupakan rasa sakit yang mereka derita. "wahai, engkau yang tidak lama lagi menjumpai cahaya matahari, berikanlah peringatan kepada Dolcino: sampaikan padanya, jika ia tidak ingin segera menyusulku di sini, buatlah persediaan makanan untuk mempersenjatai diri dari serangan salju bukan meraih kemenangan ke Novarese; tidak mudah menaklukkan. Dengan mengangkat satu kakinya, Mohammed berbicara, lalu menurunkan kakinya itu ke tanah dan berlalu.] 
Kutipan puisi di atas merupakan teks yang terkait dengan Muhammad serta penyiksaan yang dialaminya.

He eyed me, with his hands laid his breast bare,

And cired, "Now mark how I do rip me:

How is Mohammed mangled: [Ia menatapku, dengan tangannya yang bersandar di dada telanjangnya dan berseru, "sekarang saksikanlah bagaimana aku merobek dadaku: hah! Bagaimana (seorang) Muhammad begitu terkoyak...]

Muhammad digambarkan tubuhnya terbelah dan menahan rasa sakit. Hukuman ini ditujukan bagi pelaku yang selalu menyulut perpecahan ...did sow Scandal and schism... Dalam catatan kakinya, Durling (1996: 459) menyebutkan bahwa dalam polemik-polemik yang terjadi di era medieval dimana sumber-sumber informasi yang terjadi di luar Eropa hanya dapat ditemukan dari gereja, Dante mengklaim bahwa sebelum menyebarkan agama Islam, Muhammad menganut Kristen Nestorian yang menolak kepercayaan Kristen secara umum bahwa sifat keilahian dan tubuh Kristus adalah sesuatu yang tak terpisahkan. Berdasarkan penyebarannya, aliran ini pernah ditolak oleh Roma pada abad ke-5, sehingga mereka hijrah ke Persia. Sejak itu, aliran ini selanjutnya dinamakan East Church. Nestorian pun mengembangkan ajarannya di Jazirah Arab dan memiliki pemeluk yang cukup banyak.

Karena sebelumnya diduga menganut agama Kristen, maka Muhammad dituduh melakukan penyimpangan terhadap ajaran Kristen dengan membuat agama baru yang berabad-abad kemudian balik menyerang peradaban Kristen, dalam hal ini Eropa. Bukan hanya itu, teks ini juga menggambarkan beberapa 
pernyataan sarkastik yang ditujukan kepada agama dan peribadatan yang dilakukan umat Islam. Pada kalimat He eyed me, with his hands laid his breast bare. Tampak jelas bahwa posisi kedua tangan yang merapat ke dada seperti itu melambangkan salah satu posisi dalam gerakan ibadah shalat yang dilakukan umat islam pada umumnya. Sebagaimana dijelaskan pada bab sebelumnya bahwa setiap hukuman dan suasana masing-masing neraka dikaitkan dengan suatu peristiwa dalam kehidupan nyata atau dalam mitologi. Saat Dante melewati gerbang neraka, arwah-arwah penasaran yang tidak menempati surga dan sekaligus tidak disiksa di neraka melolong seperti srigala. Ini merujuk pada keputusasaan Hecuba istri Priam yang berteriak histeris saat melihat anaknya Polixena tewas dikorbankan untuk Achilles. Di neraka birahi, angin yang bertiup dengan kencang mengangkat orang-orang yang semasa hidup tidak sanggup menahan syahwatnya. Ini merujuk pada angin kencang yang berhembus beberapa saat setelah kematian Ratu Dido ketika ditinggal pergi oleh Aeneas. Atau hukuman untuk tukang penerima sogok yang ditanam di sebuah ceruk yang mirip kolam pembaptisan dikarenakan orang-orang yang berada di neraka ini adalah pemimpin-pemimpin gereja yang melegalkan pembelian Indulgensi.

Begitupun yang terjadi di neraka tempat Muhammed di hukum. Neraka Muhammed merujuk pada peribadatan yang dilakukan umat islam. Seperti yang dijelaskan di atas bahwa posisi tangan Muhammad ini merujuk pada posisi tangan umat islam dalam melaksanakan peribadatan harian, Shalat. Bagian sarkastik lainnya sekaligus penggambaran neraka di dalam teks di atas adalah sebagai berikut. 
A fiend is here behind, who his sword

Hack us thus cruelly, silvering again

Each of this ream, when we have compast round

The dismal way; [Sesosok iblis berada di belakang, yang dengan pedangnya menyabet kami dengan sadis, menebas setiap arwah yang ada di dalam rim ini. Saat kami berjalan mengelilingi jalan yang menyakitkan ini;]

Potongan teks di atas menjelaskan bahwa jiwa-jiwa putus asa ini mengelilingi batu besar untuk menerima hukuman dari iblis. Dari penggambaran ini telah menunjukkan teks tersebut memberikan sarkastik merendahkan ibadah islam yang lain yaitu ibadah haji. Ibadah haji adalah salah satu rukun ibadah wajib yang dilakukan umat islam pada bulan Haji, yaitu berziarah ke Mekah dengan mengelilingi kubus hitam yang besar yang dinamakan Ka'bah, yang mana di dalam Ka'bah terdapat batu suci bernama Hajar Aswat. Selanjutnya, untuk mempertegas bahwa ajaran yang dibawakan oleh Muhammad ajaran perpecahan yaitu dengan menghadirkan murid terbaik dan sekaligus sepupu Muhammad yang juga mengalami siksaan yang sama.

... before me

Walks Ali weeping, from the chin his face

Cleft to the forelock; [di sebelahku Ali berjalan sambil menangis, wajahnya terbelah dari dagu hingga ke ubun-ubun;]

Kalimat ini mempertegas bahwa puncak dari ajaran Muhammad adalah ajaran yang mengajarkan perpecahan. Melirik ke sejarah, Ali pernah menjabat sebagai Khalifah atau pemimpin umat Islam dari sahabat Muhammad pasca meninggalnya Sang Nabi. Khalifah terakhir dari Khulafaur Rasyidin ini memimpin Islam saat kepemimpinan Islam mengalami gonjang-ganjing politik 
dikarenakan Usman bin Affan, Khalifah sebelumnya, tewas terbunuh. Aisyah Janda sang nabi mendesak agar Ali menemukan dan segera menghukum pembunuh sang Khalifah. Karena Ali tidak menjalankan secara maksimal investigasi ini, Aisyah mengerahkan pasukan untuk menyerang Ali. Pada awal abad ke-8 meletuslah perang Unta. Meskipun Ali berhasil memukul mundur pasukan Aisyah, tidak lama kemudian Ali harus meregang nyawa akibat dibunuh oleh seseorang yang tidak dikenal saat ingin menjalankan shalat Shubuh. Sejak itu, pengikut Ali tidak bisa menerima penghinaan tersebut, apalagi anak dan cucu Ali Hasan dan Husain harus dibantai karena alasan politis oleh Raja dari dinasti Umayyah. Pengikut Ali dan keturunannya ini selanjutnya mendeklarasikan diri sebagai aliran Syi'ah. Konon sejak berdirinya aliran Islam terbesar kedua setelah Sunni ini, ketegangan dua kelompok ini tidak pernah berakhir hingga saat ini.

Dalam teks Commedia, Islam dalam hal ini ajaran Muhammad dipandang sebagai agama yang kacau. Ini dapat dilihat dalam bagan oposisi biner 2.10. Pada bagan tersebut ada beberapa oposisi yang menunjukkan adanya hirarki yang membandingkan unsur-unsur Eropa dan Kristen berada di atas pengaruh-pengaruh Islam. Segala definisi kekacauan dialamatkan pada simbol-simbol islam yaitu pada oposisi nomor (12) yaitu European dan Saracen (Arab), (13) yakni Christian dan Moslem, serta (21) Civilized dan Barbarian. Penggunaan istilah Saracen merupakan konotasi negatif bangsa Eropa terhadap peradaban timur yang direpresentasi bangsa Arab. Kesan negatif inipun dialamatkan kepada peradaban Islam sebagai bangsa yang barbarian karena bangsa Arab (Islam) selalu diidentikkan dengan perang dan menyebarkan ajarannya dengan menciptakan 
perselisihan dengan yang lain. Dalam teks ada pesan yang dititipkan Muhammad kepada Dante yang menunjukkan bahwa perang dan kekerasan adalah tradisi pengikutnya (Islam).

"Thou, who perchance

Shalt shortly view the sun, the warning thou

Bear to Dolcino: bid him, if he wish not

Here soon to follow me,..." ["wahai, engkau yang tidak lama lagi menjumpai cahaya matahari, berikanlah peringatan kepada Dolcino: sampaikan padanya, jika ia tidak ingin segera menyusulku ke sini,...']

Pesan Muhammad ini lebih mempertegas lagi bahwa ia benar-benar semasa hidupnya adalah untuk berperang, memecah belah, dan haus darah. Ia dalam Commedia menjadi contoh buruk untuk orang-orang yang lepas kendali dan mengandalkan hasrat menguasainya daripada melindungi kaumnya. Kaum barbar memberikan konotasi yang negatif mengenai peradaban perang dan perselisihan yang tidak berujung, sehingga semaju apapun peradaban di luar Eropa, dalam hal ini Arab, peradaban mereka dianggap hanya akan maju dengan cara perang dan runtuh melalui perang pula.

Dalam pada itu, Dan Brown (2013: 64) Novel Inferno menjelaskan satu fakta dalam narasi berikut:

Composed by Dante Alighieri in the early 1300s, Inferno had quite literally redefined medieval perceptions of damnation. Neverbefore had the concept of hell captivated the masses in such an entertaining way. Overnight, Dante'swork solidified the abstract concept of hell into a clear and terrifying vision - visceral, palpable, and unforgettable. Not surprisingly, following the poem's release, the Catholic Church enjoyed an enormous uptick in attendance from terrified sinners looking to avoid Dante's updated version of the underworld. [Inferno, yang disusun oleh Dante Alighieri pada awal 1300-an, secara literal mengubah persepsi 
Abad Pertengahan tentang hukuman akhirat. Sebelumnya, konsep tentang neraka tidak pernah memikat massa dengan cara yang begitu menghibur. Dalam sekejap, karya Dante membuat konsep mengenai neraka menjadi visi yang jelas dan mengerikan - mendalam, gamblang, dan tak terlupakan. Tidak mengherankan, setelah penerbitan puisi itu, Gereja Katolik mengalami peingkatan jumlah pengunjung yang luar-biasa dari para pendosa ketakutan yang ingin menghindari versi terbaru duniabawah menurut Dante.]

Dari narasi ini, jelas bahwa teks Commedia adalah teks yang efektif membangun moral ideologi bangsa Eropa klasik yang berpusat pada kekuatan Gereja tersebut. Keberadaan teks ini menciptakan perlawanan yang keras terhadap ideologi yang berada di luar garis prioritas. Namun, pertanyaan substansial kemudian apakah seiring waktu berjalan, pemikiran ini bertahan sebagai ideologi yang paten dan tidak ada yang menggugatnya.

Narasi selanjutnya memberikan penjelasan bahwa spirit teks Commedia mampu bertahan dalam zaman yang terus berubah secara ekstrim. Ini ditunjukkan narasi berikut.

In the seven centuries since itu publication, Dante's enduring vision of hell had inspired tributes, translations, and variations by some of history's greatest creative minds. Longfellow, Chaucer, Marx, Milton, Balzac, Borges, and even several popes had all written pieces based on Dante's Inferno. Monteverdi, List, Wagner, Tchaikovsky, and Puccini composed pieces based on Dante's work, as had one of Langdon's favorite living recording artists - Loreena McKennitt. Even the modern world of video games and iPad apps had no shortage of Dante-related offerings (Brown, 2013: 65) [Sejak tujuh abad setelah penerbitannya, visi neraka Dante yang terus bertahan telah menginspirasi penghormatan, penerjemahan, dan variasi oleh beberapa otak kreatif tentang sejarah. Longfellow, Chaucer, Marx, Milton, Balzac, Borges, dan bahkan beberapa Pauspernah menulis karya berdasarkan Inferno-nya Dante. Monteverdi, List, Wagner Tchaikovsky, dan Puccini menggubah komposisi berdasarkan karya Dante, begitu juga salah seorang pemusik favorit Langdon yang masih hidup - Loreena Mckennitt. Bahkan, duniamodern video games dan aplikasi iPad tidak pernah kekurangan persembahan yang berhubungan dengan Dante. 
Melalui fakta-fakta yang terpapar pada narasi di atas, spirit Commedia terus-menerus direproduksi setiap zaman. Penulis-penulis ternama seperti yang disebutkan di atas Longfellow (1807-1882), Chaucer (1343-1400), Marx (18181883), Milton (1608-1674), Balzac (1799-1850), dan Borges (1899-1986) adalah tokoh-tokoh yang merepresentasikan semangat zaman mereka. Semangat zaman ini secara eksplisit berakar pada spirit yang diusung oleh Commedia. Misalnya Marx, tokoh ini memproyeksikan pemikirannya pada realitas sosial masyarakat Eropa pada masa Revolusi Industri. Ia menganggap bahwa gereja berperan serta dalam menciptakan suasana kondusif dalam membangun kesadaran palsu kepada masyarakat tentang takdir dan cobaan. Menurut Marx, Kapitalisme dari kaum bourgeois hanya memapankan produksinya jika ditopang oleh buruh-buruh yang taat beragama. Dengan begitu, buruh-buruh yang taat akan mengurangi kesempatan bagi mereka melakukan revolusi sosial untuk memperjuangkan kelas mereka. Jika merujuk pada narasi novel Inferno di atas yang secara tersirat mengatakan bahwa tokoh-tokoh ini masih mengusung semangat Dante, maka Marx, dapat dikatakan, telah men-generalisir apa yang ditangkapnya bahwa konstruksi sosial yang ada di Eropa berlaku untuk semua konstruksi masyarakat di dunia. Ini dikarenakan Commedia bukan hanya membuka ruang untuk nakal dalam bertutur, sehingga membuka pintu diskusi di setiap zamannya, tetapi juga menyisipkan hirarki simbolik yang kokoh. Pengarang tampak ingin mengungkapkan bahwa Marx masih memandang dunia dalam ruang yang sangat parsial. Paradigma demikian juga terbentuk pada tokoh-tokoh yang telah disebut namanya di atas. 
Hal demikian ini terjadi karena oposisi-oposisi yang disisipkan Dante memandang sebelah mata dunia Timur. Marx dan tokoh-tokoh seperti Milton dan Borges sekalipun tidak menyadari bahwa kondisi belahan dunia lain tidak tampak seperti itu. Agama yang dipandang oleh pemikir pasca-Renaissance menyimpan kebobrokan telah digeneralkan. Mereka menganggap agama adalah opium yang membuat pemeluknya berhalusinasi. Padahal jika kita menarik ke garis sejarah, agama awalnya hadir untuk membangun tatanan masyarakat yang realistis dan menolak adanya penindasan dari pihak manapun, apapun caranya. Oposisi biner dalam Commedia dengan menempatkan posisi Timur dalam hal ini Arab, dan Islam sebagai peradaban yang chaos membuat realitas peradaban non-Eropa ini tidak teridentifikasi bahkan menjadi peradaban yang sub-ordinat. Semangat ini menjadi batu pijakan pemikiran kolonialisme.

Pengarang, dari pembacaannya terhadap karya-karya yang terinspirasi dari Dante ini, memandang selama ini politik global dunia diselimuti oleh pergesekan oleh dua entitas yang beroposisi satu dengan yang lain, Barat-Timur, UtaraSelatan, Pusat-Pinggir, Protagonis-Antagonis. Isu demikian bukanlah hal yang baru. Pasca meletusnya peristiwa 11 September 2001, banyak pemikir menganggap ramalan Samuel Huntington dalam artikelnya Clash of Civilization telah terjadi. Ada peradaban yang merasa diabaikan, direndahkan, dan diinvasi hingga tidak tampil dalam wacana global. Kekecewaan ini dikarenakan kekuatan barat yang didominasi Eropa dan Amerika baik dalam perpolitikan, religiusitas, maupun keilmuan membungkam potensi-potensi peradaban di luar lingkaran mereka dengan mengeneralkan pengalaman bernegara mereka yang panjang 
kepada negara-negara Timur. Padahal negara-negara timur mempunyai sejarah dan kepribadian bangsanya sendiri. Beberapa menerima pemikiran barat secara total. Sebahagian butuh diadaptasi ke dalam sosio-kultur bangsa mereka, dan sebagian yang lain menolak dengan tegas dan memberikan perlawanan.

Salah satu contohnya adalah penerapan negara sekuler. Sekularisasi sistem pemerintahan pasca Revolusi Perancis di negara-negara barat dipandang efektif untuk membangun negara yang tidak terintervensi oleh moralitas agama. Oleh karena itu, mereka memaksakan negara-negara timur untuk membangun negara sekuler sebagaimana yang mereka terapkan selama ini. Ketidak-percayaan politisi terhadap kerja-kerja agamawan dalam membantu birokrasi di negara-negara Eropa seperti Itali dan Perancis tentunya tidak akan sama jika diterapkan di negara timur. Kebanyakan negara timur dibangun oleh spirit keagamaan yang kokoh. Sebagian di antaranya memiliki hukum positif berlandaskan pada hukum agama, seperti negara Pakistan. Beberapa di antaranya memiliki penasehat utama Presiden seorang ahli Agama, seperti negara Iran dengan Ayatullah Qomeni pasca revolusi Iran. Gerakan teologi pembebasan pada pertengahan tahun 2000-an di Amerika Latin adalah sebuah perkawinan agama dan semangat perjuangan sosialisme yang tidak pernah terbayangkan di dunia barat.

Oleh karena itu, memperhatikan clash yang sudah demikian radikal, pengarang melalui pembacaannya terhadap teks Dante mencoba kembali menegosiasikan jejak yang dihadirkan teks The Divine Comedy. Jika dirunut dari kompleksitas konteks hingga ke dalam teks Dante sesuai dengan pemaparan di 
atas, maka ditemukan akar persoalan yang menjadi sebab oposisi ini bertahan hingga saat ini, dapat dilihat pada bagan di bawah ini.
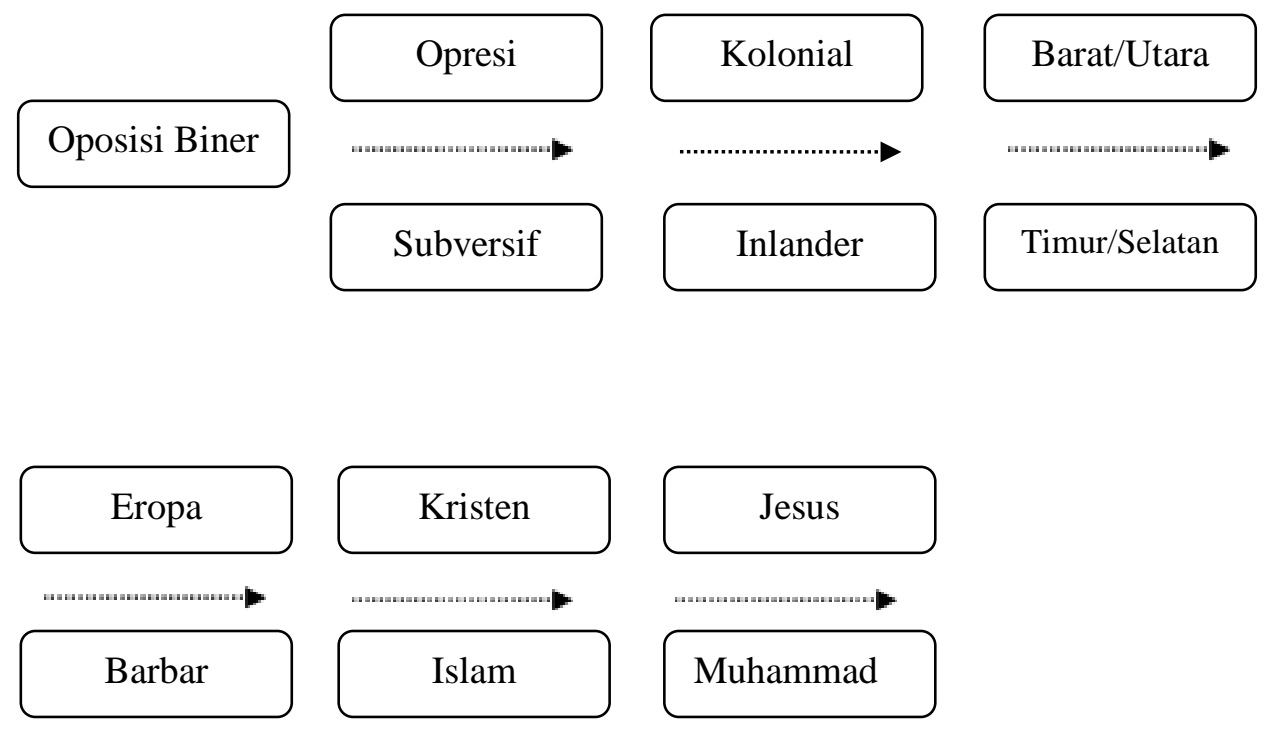

Bagan 3.1 Skema penelusuran oposisi biner

Dari skema di atas, dapat dipaparkan bahwa tragedi 911 dan aksi-aksi terorisme yang terjadi di berbagai belahan dunia ini bukanlah gesekan peradaban yang muncul secara tiba-tiba. Kecurigaan yang berlebihan kedua oposisi ini bermuladari abad Dante masih hidup, secara frekuentif direproduksi. Jika merujuk kembali pada pertanyaan di awal sub-bab ini, mengapa Commedia terus-menerus direproduksi. Ini bukan hanya sekadar estetika sebuah karya sastra, tetapi misi ideologis yang diusung pihak tertentu, dalam hal ini gereja.

Not surprisingly, following the poem's release, the Catholic Church enjoyed an enormous uptick in attendance from terrified sinners looking to avoid Dante's updated version of the underworld. (Dan Brown: 64, 2013) [Tidak mengherankan, setelah penerbitan puisi itu, Gereja Katolik mengalami peningkatan jumlah pengunjung yang luar-biasa dari para pendosa ketakutan yang ingin menghindari versi terbaru duniabawah menurut Dante.] 
Dan Brown, dalam novel Inferno, melihat bacaan Commedia sebagai model paling efektif oleh gereja dalam menanamkan misi-misi semangat medieval dalam konteks kekinian. Dalam narasi yang lain menjelaskan bahwa hingga saat ini Commedia menjadi bacaan alternatif anak-anak Kristen. Fakta ini diungkapkan oleh pengarang yang direpresentasikan melalui tokoh (Felicity) Sienna Brooks yang merupakan anak dari sepasang suami istri yang taat. Tentunya sebagai seorang yang datang dari keluarga Kristen ia pernah mengenal nama Dante.

... "Well tell me, what do you know about Dante?"

The pretty, young blonde shrugged, "just what everyone learns in school. Dante wasan Italian poet most famous for writing The Divine Comedy, which describes his imagined journey through hell." (Brown; 165, 2013).

[...'Wah, katakan, apa yang Anda ketahui mengenai Dante?"

Perempuan muda cantik berambut pirang itu mengangkat bahu. "Hanya apa yang dipelajari oleh semua orang di sekolah. Dante adalah penyair Italia yang paling dikenal karena menulis The Divine Comedy, yang menjelaskan perjalanan khalayannya melewati neraka”]

Dijelaskan dalam narasi di atas bahwa bukan hanya gereja, sekolahpun turut membantu memperkenalkan anak-anak di Eropa tentang Dante dan Commedia. Fakta dari Brown ini memberikan suatu kesadaran bahwa moralitas yang dibangun secara hirarkis sebagaimana dijelaskan sebelumnya dimulai sejak anakanak di sekolah. Pengarang juga menyampaikan ini melalui narasi yang lain dengan mengatakan Sienna pertama dan terakhir membaca Commedia pada usia tujuh tahun.

What is he talking about? Sienna bounded after him, feeling lost.

“Did you ever read Inferno?” Lngdon asked. 
Yes... but think I was seven.

An instant laater, it dawned on her. "Oh, satan naval!” She said. "Now I remember."

It had taken a moment, but Sienna now realized hatLangdon was referring to the finale of Dante's Inferno. In these cantos, in order to escape hell, Dantehas to climb down the hairy stomach of the masive Satan, and when he reaches Satan's navel - the alleged center of the earth - the earth's gravity suddenly switches directions, and Dante, in order to continue climbing down to purgatory... suddenly has to start clambing up.

Sienna remembered little of the Inferno oher than her dissapointment in witnessing the absurd action of the gravity at the center of the earth; apparently Dante's genius did not include a grasp of the physics of the vector forces. (Brown: 195, 2013).

[Dia bicara apa? Sienna berlari menyusul, merasa kebingungan.

“Kau pernah membaca Inferno?” tanya Langdon

Ya... tapi saat itu usiaku tujuh tahun.

Sejenak kemudian, Sienna mengerti. "Oh, pusar iblis!” katanya. "Aku ingat."

Perlu sejenak, tapi kini Sienna menyadari bahwa Langdon mengacu pada akhir dari Inferno Dante. Dalam canto-canto akhir, untuk lolos dari neraka, Dante harus menuruniperut berbulu iblis yang besar, dan ketika dia mencapai pusar - konon pusat bumi - gravitasi mendadak berubah arah sehingga Dante, untuk terus turun menuju penebusan... mendadak harus memanjat naik.

Sienna hanya ingat sedikit tentang Inferno. Dia hanya ingat ia kecewa membaca aksi gravitasi yang absurd di pusat bumi; tampaknya kegeniusan Dante tidak menyertakan pemahaman fisika gaya vektor.]

Dari potongan dialog di atas, pengarang memberikan pemahaman bahwa Commedia bukanlah bacaan yang asing untuk orang-orang Eropa. Mereka telah diperkenalkan puisi Dante ini sejak usia dini, yaitu usia tujuh tahun. Mereka mengenalnya baik melalui gereja maupun pelajaran sastra di sekolah-sekolah formal. 
Walaupun tidak berprofesi sebagai seorang penyair, seniman, atau simbolog seperti Robert Langdon, karakter Sienna tahu banyak mengenai Commedia. Sienna merepresentasikan orang-orang Eropa. Pengarang secara tersirat ingin menyampaikan bahwa hampir keseluruhan orang-orang Eropa pernah membaca atau sekedar mengenal The Divine Comedy. Sienna yang berkebangsaan Inggris juga tahu tentang puisi Dante.

Sienna Frowned. "But this city probably has dozens of gates"

"Yes, which is why we need to read Canto Twenty-five of Paradise."He gave her a hopeful smile. "You don't, by any chance, know the entire Divine Comedy by heart, do you?"

She gave him a dumb look. "Fourteen thousand lines of archaic Italian that I read as a kid?" She shook her head. "You'rethe one with the freakish memory, Professor. I'm just a doctor. (Brown, 2013: 200) gerbang."

[Sienna mengernyit. "Tapi, kota ini mungkin punya lusinan

"Ya, itulah sebabnya kita harus membaca Paradiso canto dua puluh lima." Langdon mengulaskan senyum penuh harap. "Kau tidak kebetulan hafal seluruh Divine Comedy, bukan?

Sienna memandangnya dengan ekspresi konyol. "Empat belas ribu baris bahasa Italia kuno yang kubaca semasa kecil?" Dia menggeleng. "Kaulah yang punya ingatan hebat, profesor. Aku hanya dokter."

Pengenalan Dante sejak dini adalah sebuah misi penanaman identitas, terutama dalam membangun hirarki dalam memahami identitas-identitas di luar dari mereka. Sebagaimana dijelaskan sebelumnya, Eropa berupaya menjadi sentral peradaban dunia. Salah satu caranya adalah dengan memperkenalkan karya-karya yang mendukung upaya tersebut, membangun spirit dengan kejayaan masa lalu. Dengan cara demikian, Identitas ini terkapsul menjadi ideologi paten bangsa 
Eropa yang pongah dengan peradaban dan kemajuannya sehingga menganggap sebagai pemberi kontribusi kemajuan terbesar dan satu-satunya di dunia.

Alih-alih mengagungkan karya Dante sebagaimana karya-karya besar sebelumnya yang merespon Commedia, Pengarang novel Inferno melakukan pemlestan simbol-simbol agung yang tertata secara hirarkis dalam puisi tersebut. Pada dasarnya, Dan Brown sudah membidik simbol-simbol sentral ini di dalam novel sebelumnya. The Lost Symbol memberikan informasi secara implisit bahwa kebudayaan itu tidak secara ekstrim kaku dan tertutup oleh selubung kapsul yang mensterilkan dirinya dari pengaruh luar. Padahal sejarah telah menegaskan bahwa kebudayaan itu mengalami pertukaran, saling pinjam dan menjadi bagian dengan yang lain. Dalam The Lost Symbol, pengarang membagi informasi bahwa kebudayaan Arab telah memberi kontribusi besar dalam sistem numerik yang digunakan Eropa hingga saat ini.

Begitu pula dalam petualangan Langdon yang pertama dalam novel Angels and Demons mengatakan bahwa kata Satan(ic) adalah kata yang diadopsi dari bahasa arab (Islam) untuk mengekspresikan umpatan yang paling hina terhadap satu perilaku, sesuatu, atau seeorang. Dengan begitu, dapat disimpulkan bahwa kebudayaan itu bersifat cair. Seiring waktu berjalan, keran kebudayaanpun semakin terbuka, mengalir dengan deras bersama kebudayaan-kebudayaan yang lain membentuk warnanya sendiri, Sehingga mustahil untuk mencacahnya kembali ke dalam ruang-ruang yang parsial. Pengarang ingin menyampaikan bahwa seseorang atau sekelompok ras tertentu tidak berhak mengatakan bahwa kebudayaan atau satu kearifan yang tampak di hadapannya saat ini adalah 
miliknya. Secara metaforik, parit-parit kebudayaan telah menyatu satu dengan yang lain di kanal utama. Gesekan mudah saja terjadi, disebabkan arus-arus tersebut saling menindih dengan yang lain untuk muncul di permukaan, tidak ingin menjadi endapan lumpur di dasar dan ditinggalkan. Oleh karena itu, dibutuhkan emulator universal yang bisa membaurkan arus-arus yang berwarnawarni tersebut. Emulatornya adalah toleransi.

Sikap toleransi yang diusulkan Dan Brown dalam teks Inferno adalah dengan memadamkan hirarki antara kedua kutub yang saling mengklaim kekuasaan tersebut.

Langdon glanced over at Bruder and Sinskey, who had been staring upward and who now lowered their eyes to earth.

“Jesus,” Bruder said.

"Yes!” Mirsat said excitedly. "And Allah and Muhammad, too!

Landon chuckled as their guide directed Bruder's gaze to the main altar, where a towering mosaic of Jesus was flanked by two massive disks bearing the Arabic names of Muhammad and Allah in ornate calligraphy.

"This museum," Mirsat explained, "in an effort to remind visitors of the diverse uses of this sacred space, displays in tandem both the Christian iconography, from the days when Hagia Sophia was a basilica, and the Islamic iconography, fromits days as a mosque." He gave a proud smile. "Despite the friction between the religions in the real world, we think their symbols work quite nicely together. I know you agree, professor."

Langdon gave a heartfelt nod, recalling that all of the Christian iconography had been covered in whitewash when the building became a mosque. The restortion of the Christian symbols next to the Muslim symbols had created a mesmerizing effect, particularly because the styles and sensibilities of the two iconographies are polar opposites. (Brown, 2013: 394).

[Langdon melirik Sinskey dan Bruder, yang tadi juga mendongak dan kini menundukkan wajah mereka. 
“Demi Yesus," kata Bruder. Muhammad!"

"Ya!" ujar Mirsat penuh semangat. "Dan juga Allah dan

Langdon terkekeh saat pemandu mereka mengarahkan pandangan ke Bruder ke altar utama tempat mozaik besar Yesus diapit oleh dua lingkaran raksasa bertuliskan Muhammad dan Allah dengan kaligrafi Arab yang cantik.

"Museum ini," Mirsat menjelaskan, "sebagai upaya untuk mengingatkan pengunjung akan keanekaragaman penggunaan tempat sakral ini, memamerkan ikonografi Kristen, dari masa ketika Hagia Sophia berfungsi sebagai basilika, dan ikonografi Islam, dari masa ketika bangunan ini menjadi mesjid." Dia menyunggingkan senyuman bangga. "Walaupun terdapat friksi antar-agama di dunia nyata, menurut kami simbol-simbol ini tampak bagus saat disandingkan. Saya tahu bahwa anda sependapat Professor."

Langdon mengangguk sepenuh hati, teringat bahwa semua ikonografi Kristen pernah dilebur dengan kapur putih ketika bangunan ini menjadi mesjid. Restorasi simbol-simbol Kristen di samping simbol-simbol Islam telah menciptakan efek menakjubkan, terutama karena gaya dan rasa kedua ikonografi tersebut bertolak belakang.]

Penampakan altar utama dan dinding di sekitarnya di Hagia Sophia tidaklah bermakna apa-apa jika tidak dibentuk dalam narasi yang canggih. Pengarang berusaha menaruh teks dalam situasi yng tepat, dimana dua tokoh, yaitu Mirsat dan Bruder, berbeda latar-belakang budaya dan ideologi saling menyambut ketakjuban simbol-simbol ketuhanan dengan bahasa masing-masing. Perdamaian dua tokoh ini merepresentasikan suatu keterbukaan menerima perbedaan cara pandang. Mozaik Yesus yang diapit dua kaligrafi Islam, Muhammad dan Allah, merupakan perpaduan unik dua simbol tradisi yang selama berabad-abad yang lalu tidak pernah dibayangkan akan berada di dinding yang sama. Narasi ini sangat jelas menggambarkan sebuah dekonstruksi atas strata eskatologis yang dibangun oleh Dante. Sebagaimana yang telah dijelaskan 
beberapa kali sebelumnya bahwa Muhammad berada di kedalaman neraka kedelapan Malebolge parit ke sembilan sedangkan Yesus jauh di atas puncak langit Empyrean, Mereka bertemu di dinding sebuah bangunan megah yang dibangun oleh Kristen abad pertengahan.

Salah satu yang menakjubkan adalah informasi dalam novel yang mengatakan bahwa simbol-simbol kristen di bangunan ini pernah dilebur dengan kapur. Pernyataan ini bukan hanya sekadar menyampaikan suatu fakta historis tetapi menggambarkan bahwa konflik dua entitas logosentrisme ini pada masa itu masih sangat kuat. Oleh karena itu, melajutkan pernyataannya,

... The restortion of the Christian symbols next to the Muslim symbols had created a mesmerizing effect, particularly because the styles and sensibilities of the two iconographies are polar opposites. [Restorasi simbol-simbol Kristen di samping simbol-simbol Islam telah menciptakan efek menakjubkan, terutama karena gaya dan rasa kedua ikonografi tersebut bertolak belakang.]

Adanya restorasi interior gedung Hagia Sophia adalah satu kemajuan bahwa proyek toleransi yang merupakan emulator dua ideologi ini sedang berjalan. Ketakjuban yang ingin ditonjolkan pengarang bukan disebabkan oleh kaligrafi dan mozaik yang ada, akan tetapi kerelaan pemangku kebijakan negara Turki, yang menginginkan Hagia Sophia menjadi museum atau warisan budaya dunia yang tidak lagi dikonversi menjadi bangunan peribadatan agama tertentu. Pengarang merindukan masyarakat dunia mau menciptakan rasa damai yang mendalam sebagaimana dia menggambarkan damainya Mirsat dan Bruder memuji kebesaran historis masing-masing dengan hati yang terbuka. Sayangnya, 
pengarang menyadari dirinya sedang ber-utopia dengan mengatakan He gave a proud smile. "Despite the friction between the religions in the real world,..."

Namun dengan novel ini, Dan Brown menawarkan harapan bahwa manusia yang berusaha mencari akar sejarah dirinya, bangsa, dan keyakinannya akan menemukan kebijaksanaan bahwa diri, bangsa, dan ideologinya adalah bagian dari sekelumit jaring kebijaksanaan yang saling kait-mengait satu dengan yang lain. Pikiran individu modern yang menyadari dirinya - mirip interior bangunan Hagia Sophia yang dipandang Langdon, Sinzkey, Mirsat dan Bruder menyimpan keagungan mozaik kehidupan yang sangat luas dan indah yang diwarnai dengan berbagai arsitektur pemikiran dari zaman ke zaman, visi kehidupan, dengan segala kearifan yang diserap pendahulu mereka. Oleh karena itu, Individu mestinya berterima kasih kepada kearifan masa lalu, dari manapun datangnya, dengan menyingkirkan leburan kapur egoisme identitas keagamaan yang melekat dalam dirinya. Agama, simbol-simbol keagamaan, dan ritual, berjalan sesuai sistematika yang ada dalam tuntunan. Sebagian menolak akulturasi, dan sebagian yang lain menerimanya. Individu yang toleran bukanlah individu yang menganut semua keyakinan, bukan pula menolak keberadaan mukjizat karena Mukjizat dipercaya sebagai fenomena kosmos dalam diri manusia-manusia pilihan untuk menjawab keraguan manusia yang paling dalam. Manusia yang beragama, apapun itu, sepantasnya menyadari bahwa mereka terlahir dari persenggamaan ribuan agama, kebudayaan, kepercayaan, dan ideologi di masa silam. 
Oleh karena itu, dapat disimpulkan bahwa menjadi seorang beragama berarti menjalankan keyakinan sebagai ungkapan rasa syukur atas kehidupan yang tanpa keraguan, dan juga menjaga keselarasan hubungan kemanusiaan kepada siapapun sebagai ucapan terima kasih atas warna-warni kebijakan, mozaik pemikiran, dan kebudayaan masa lalu yang tertanam dalam pikiran kita melalui mereka.

\subsubsection{Perempuan, dan Hasrat Menghuni Neraka}

Dalam setiap diskursus, pertanyaan mengenai posisi perempuan masih begitu ambigu. Realitas yang dibangun melalui teks seringkali mengarahkan posisi perempuan sebagai second sex. Fase-fase peradaban mendedikasi perempuan sebagai media kekuasaan yang tidak punya kuasa. Dalam mitologimitologi kuno, hingga kisah-kisah epik perempuan menempati posisi yang kurang menguntungkan dalam perebutan kekuasaan. Inferno karya Dan Brown mengusung wacana kritik gender terhadap teks Commedia, melalui karakter rekaannya.

Untuk mendalami lebih jauh wacana gender, sebelumnya akan dibahas masing-masing tokoh dalam fiksi ini. Novel Inferno memiliki empat karakter perempuan menonjol, yaitu Sienna Brooks, Martha, Dr Sinzkey dan Vayentha. Sienna Brooks atau Felicitty Sienna Brooks adalah tokoh perempuan cantik yang mendampingi hampir keseluruhan petualangan Robert Langdon dalam Novel ini. Ia terlahir dengan struktur otak kecil yang berbeda, sehingga memiliki kecerdasan yang super tinggi. Kepalanya plontos, namun ia menutupi kepalanya dengan wig. 
Terlahir berbeda, Sienna dan teman-temannya beberapa tahun memilih hidup sebagai penolong orang-orang kelaparan di berbagai belahan dunia. Namun karena sebuah peristiwa di Manila-Filiphina Ia memilih kembali menjadi saintis. Ia memiliki nama samaran FS 2080. Nama samaran ini ia dapat dari organisasi yang dikenal dengan Transhumanis. Ia bekerja di perusahaan yang bergerak di bidang penciptaan ilusi. Ia juga seorang dokter dan ia terjerat dalam cinta bersama seorang dokter kontroversial Bertrand Zobrist. Sebagai seorang kristen dan berkebangsaan Inggris, Sienna dapat bertukar pendapat megenai karya seni yang merupakan jejak Dante di Florence. Di luar dari itu, ia memiliki keterampilan lebih yaitu ahli beladiri.

Dr. Sinskey adalah seorang Dokter dengan reputasi yang sangat tinggi. Ia adalah pemimpin salah satu organisasi naungan PBB yang bergerak di bidang kesehatan WHO. Sebagai pemimpin organisasi kesehatan dunia, ia merasa bertanggungjawab untuk mencegah ancaman wabah yang dilancarkan Zobrist. Diceritakan Sinzkey memiliki rambut perak. Meskipun usianya di atas 50 tahun tetapi kecantikannya masih tampak dari wajahnya. Memiliki kekuasaan tidak membuatnya bahagia, Ia merasa tidak sempurna sebagai seorang wanita disebabkan rahimnya yang sudah disterilkan pada saat usianya masih sangat muda. Ia mengagumi karya-karya klasik terutama lukisan-lukisan mengenai Venus.

Vayentha adalah seorang profesional yang dipekerjakan Consorsium untuk menciptakan ilusi teror bagi Langdon. Menggunakan Jaket kulit, motor sporty, dan rambut berduri membuat Vayentha memiliki kesan sebagai seorang 
perempuan yang mengambil profesi laki-laki. Ia ditugaskan Konsorsium sebagai seorang pembunuh bayaran untuk mnghabisi nyawa Langdon. Namun dalam akhir cerita, Vayentha harus meregang nyawa terbunuh oleh Sienna, akibat menyalahi prosedur dengan membongkar rekayasa yang ia lakukan selama ini kepada Langdon.

Martha adalah sejarawan dan sekaligus pengelola museum Medici. Sebagai seorang ahli, ia tahu banyak mengenai Dante Alighieri dan memiliki perspektif tersendiri mengenai Dante terutama dalam aspek romantika. Pada saat bertemu dengan Langdon dan Sienna, Martha dalam keadaan hamil tua. Ia merasa dirinya telah ditipu dua kali oleh tokoh pujaannya, Robert Langdon karena Langdon telah mencuri harta Museum Medici yang sangat berharga yaitu topeng kematian Dante.

Setelah memaparkan masing-masing karakter perempuan di atas, Pengarang merekayasa karakter Vayentha sebagai sosok yang tampak berbeda memahami karya seni agung yang merepresentasikan karya Dante adalah Vayentha. Baik Sienna, Martha Alvares, maupun Dr Sinzkey secara umum mampu memberikan penjelasan konkret mengenai peristiwa-peristiwa historis dan estetis di balik karya-karya seni agung yang merujuk pada Commedia. Selain dari itu, ketiga perempuan ini menunjukkan naluri mendasar secara umum seorang wanita, yaitu lemah, dan jatuh cinta seperti yang dialami Sienna berikut ini.

The flirtation is clearly inappropriate, but it is a snowy night in a deserted Chicago Hotel, and it feels as if the entire world has stopped.

"So what do you think?" Zobrist says. "Nightcap in my room?" 
I freee, knowing I must look like a deer in the headlights. I don't know what to do this!

Zobrist eye twinkle warmly. "Let me guess," he whispers. "You've never been with a famous man."

I feel myself flush, fighting to hide a surge of emotions embrassment, excitement, fear. "Actually, to be honest," I say to him, "I've never been with anyman" (Brown, 2013: 355).

[Rayuan ini jelas tidak pantas, tapi ini malam bersalju di sebuah hotel Chicago yang sepi, dan rasanya seakan seluruh dunia berhenti bergerak.

"Jadi, bagaimana menurutmu?" Tanya Zobrist. "Minum sebelum tidur di kamarku?"

Aku membeku, menyadari diriku pasti tampak seperti kijang yang terkena sorotan depan mobil. Aku tidak tahu harus bagaimana!

Mata Zobrist berkilat-kilat hangat. Biar kutebak," bisiknya. "Kau belum pernah bersama lelaki terkenal."

Aku merasakan diriku tersipu-sipu, berupaya menyembunyikan luapan semua emosi - rasa malu, rasa senang, rasa takut. "Sesungguhnya, sejujurnya," kataku padanya, "aku belum pernah bersama lelaki manapun."']

Perempuan memimpikan hamil dan memiliki anak seperti yang dialami

Marta Alvares dan Dr. Sinzkey. Martha tengah hamil besar saat bertemu dengan

Langdon. Dan telah melahirkan ketika Langdon ingin menyerahkan Death Mask

Dante

"Scusi?" Landon called. "Dove passo trovare Marta Alvares?"

The docent broke into a broad grin. "Signora Alvares?! She no here! She have baby! Catalina! Molto Bella!” (Brown, 2013; 460).

["Scusi? - Permisi?" Seru Landon. "Dove passo trovare Marta Alvares? - Bisakah saya bertemu Marta Alvares?"

Si pemandu tersenyum lebar. "Signora Alvares?! - Nyonya Alvares?! Dia tidak ada di sini! Dia sudah melahirkan! Catalina! Molto bella] 
Dalam konstruksi masyarakat, kesempurnaan seorang perempuan dapat dilihat dari kemampuan biologis mereka untuk hamil dan menghasilkan anak dari pasangan sex nya. Oleh karena itu, Dr. Sinzkey, meskipun telah meraih banyak prestasi dan karir luar biasa di dunia kesehatan yang tidak banyak orang-orang di dunia ini mampu meraihnya, merasa sangat kekurangan karena problem kemandulannya itu. Bahkan ia mengalami masa-masa sulit karena ditinggal kekasihnya setelah tahu bahwa Sinzkey steril sejak kecil.

Years ago, while in med school, she had come to Venice with her fiancé and stopped to visit the Murano Glass Museum. There, her fiancé had spied a beautiful handblown mobile and innocently commented that he wanted to hang one just like it someday in their baby's nursey. Overcome with guilt for having kept a painful secret far too long, Elizabeth finally leveled with him about her childhood asthma and the tragic glucocorticoid treatments that had destroyed her reproductive system.

Whether it had been her dishonesty or infertility that turned the young man heart to stone, Elizabeth would never know. But one week later, she left Venice without her engagement ring.

Her only memento of the heartbreaking trip had been a lapis lazuli amulet. The Rod of Asclepius was a fitting symbol of medicine - bitter medicine in this case - but she had worn it every day since. (Brown, 2013: 308)

[Bertahun-tahun silam, ketika masih kuliah di fakultas kedokteran, dia pergi ke Venesia bersama tunangannya dan mengunjungi Murano Glass Museum. Di sana, tunangannya melihat hiasan gantung kaca tiup cantik dan tanpa berpikir panjang berkomentar bahwa dirinya ingin menggantungkan hiasan semacam itu di kamar bayi mereka kelak. Tersiksa oleh rasa bersalah karena telah menyimpan rahasia menyakitkan terlalu lama, Elizabeth akhirnya menjelaskan kepadanya tentang penyakit asma yang dideritanya semasa kanak-kanak dan perawatan glucocorticoid tragis yang telah merusak system reproduksinya.

Hingga kini, Elizabeth tidak mengerti apakah hati pria itu telah berubah menjadi batu karena Elizabeth berbohong atau karena mandul. Namun yang jelas, sepekan kemudian, Elizabeth meninggalkan Venesia tanpa cincin pertunangannya. 
Satu-satunya kenangan dari perjalanan yang menghancurkan hati itu adalah sebuah jimat lapislazuli. Tongkat Asclepius merupakan symbol pengobatan - pengobatan pahit dalam hal ini - namun sejak saat itu Elizabeth memakainya setiap hari.]

Dåri penelusuran mengenai tiga karakter perempuan di atas, Dan Brown tidak menyisipkan materi kritik terhadap Commedia melalui karakter-karakter perempuan tersebut. Berbeda dengan Vayentha, karakter ini memiliki latarbelakang prinsip dan bentukan identitas yang berbeda. Vayentha diceritakan sebagai sosok perempuan yang kecenderungan dirinya yang maskulin. Ia seorang profesional di bidang menciptakan ilusi terror.

At the moment the provost was waiting to hear from one field agent particular.

Vayentha he thought, picturing the sinewy, spike-haired specialist. Vayentha, who had served him perfectly until the mission, had made a mistake last night that had dire consequences. The last six hours had been a scramble, a desperate attempt to regain control of the situation. (Brown, 2013: 20)

[Saat ini Provos sedang menunggu berita dari seorang agen di lapangan.

Vayentha, pikirnya, sambil membayangkan agennya yang berotot dan berambut duri itu. Vayentha - yang telah melayaninya dengan sempurna hingga misi ini - semalam melakukan kesalahan dengan konsekuensi mengerikan. Enam jam terakhir adalah perjuangan, upaya mati-matian untuk merebut kembali atas situasi ini.]

Vayentha yang digambarkan sebagai perempuan dengan lengan berotot dan model rambut spike ini tidak memiliki identitas perempuan sebagaimana umumnya. Pada bagian lain, agen andalan Provos ini mengenakan jaket dan celana kulit. Untuk bepergian ia kerap menggunakan motor BMW. Diceritakan pula sebagai seorang spesialis pencipta ilusi teror, ia belum pernah gagal dalam kurun waktu 15 tahun bekerja di konsorsium. Misi terakhir yang ditugaskan kepadanya adalah 
membuntuti dan mengejar Robert Langdon hingga ke museum Hall of Five Hundred.

Berbeda dengan tiga tokoh perempuan sebelumnya, Vayentha tidak memiliki citra historis dan rasa seni apapun, kecuali seni dalam menciptakan ilusi teror sebagaimana pekerjaannya. Oleh karena itu, ketika berada di lingkungan patung-patung bernilai seni agung di perbatasan Piazza della signoria, Vayentha tampak bernegosiasi dengan alam kenyataan. Orang-orang mencintai karya seni yang mengagungkan penyiksaan pada perempuan.

Vayentha had abandoned her motorcycle just north of the Palazzo Vecchio and approaching on foot along the perimeter of the Piazza della Signoria. As she wound her way through the Loggia dei Lanzi's outdoor statuary, she could not help but notice that all the figures seemed to enacting a viriation on a single theme: violent display of male dominance over women.

The rape of Sabines

The Rape of Polyxena

Perseus Holding the severed Head of Medusa

Lovely, Vayentha, thought.... (Brown, 2013: 181)

[Vayentha meninggalkan sepeda motornya di utara Palazzo Vecchio, dan menuju bangunan itu dengan berjalam kaki di sepanjang perbatasan Piazza della SIgnoria. Ketika berjalan berkelok-kelok melewati patung-patung di luar ruangan di Loggia dei Lanzi, mau tak mau dia memperhatikan bahwa semua sosok itu seakan memperagakan variasi dari satu tema tunggal: pertunjukan keji dominasi kaum lelaki terhadap perempuan.

The rape of Sabines. Pemerkosaan perempuan-perempuan Sabine.

The Rape of Polixena. Penyiksaan Polyxena.

Perseus Holding the severed hand of Medusa. Perseus memegang Kepala Medusa yang terpenggal.

Menyenangkan, pikir Vayentha...] 
Menciptakan karakter yang tidak memiliki latar pengetahuan sejarah dan seni mempermudah Dan Brown menyusun kritik terhadap teks hipogramnya. Narasi di atas dapat dibandingkan, dengan narasi berikut ini mengenai penilaian Sienna terhadap patung-patung yang berada di tempat yang sama sebelum kedatangan Vayentha.

"I can't believe I've never been here" Sienna whispered beside him, her voice suddenly quiet and reverent. "this is ... beautiful." (Brown, 2013:150)

["Aku tidak percaya kalau aku tidak pernah kemari," bisik Sienna di samping Langdon, suaranya mendadak pelan dan hormat. “... indah”]

Sikap Vayentha, berbeda dengan Sienna yang tersubjeksi oleh kemegahan karyakarya agung tersebut, membuka tabir betapa pertunjukan mengenai perempuan yang tidak mendapatkan ruang keadilan itu akan indah di setiap zaman. Ketiga patung yang direspon oleh Vayentha merepresentasikan perlakuan teks Commedia terhadap perempuan. Dalam the Divine Commedy, Perempuan ditempatkan seperti emas yang mulia, tetapi berbahaya jika memiliki ruh. Perempuan tidak memiliki kuasa atas dirinya. Mereka hanya mengalir atas inisiatif kuasa yang membentuknya.

The Rape of Sabines adalah patung yang merepresentasikan dialog Dante dan kaisar Justanian di alam surga. Justanian memuji tindakan raja Romulus saat mengerahkan pasukannya untuk memperkosa perempuan-perempuan Sabine agar mereka mendapatkan keturunan tangguh dari campuran gen Sabine dan Roma. Tindakan keji demikian telah mengakar, dan dibiarkan menjadi virus dalam spirit zaman. Bgitu pula kekejian yang di-iya-kan setiap zaman pada tragedi The Rape 
of Polyxena. Penyiksaan terhadap Polyxena awalnya diceritakan oleh Homer dalam Illiad. Dalam tragedi tersebut, Achilles jatuh cinta pada Polyxena. Dalam wasiatnya sebelum meninggal, Achilles meminta kepada pasukannya agar Polyxena harus menemaninya di alam keabadian/kematian. Oleh karena itu, Polyxena, oleh pasukan Achilles, dibakar hidup-hidup di dekat pembakaran mayat Achilles. Meskipun tidak diceritakan secara detail mengenai aksi pemerkosaan ini, Dante - dalam The Divine Commedy - ketika berjalan memasuki neraka, dia mendengar lolongan suara manusia yang mengiris. Ia menganalogikan lolongan itu seperti lolongan keputus-asaan ibu Polyxena disebabkan tidak bisa berbuat apa-apa saat suaminya tewas terbunuh dan putrinya dibakar hidup-hidup.

Cibiran Vayentha, oleh pengarang, merepresentasikan sikap politik dan tragedi perang yang seringkali menempatkan perempuan sebagai korban. Mereka bahkan tidak menempatkan para korban-korban perempuan ini sebagai pahlawan. Mereka hanya dikenang sebagai istri dari... atau $i b u$ dari... Pengarang dalam kesempatan tersebut membuat suatu perhitungan terhadap keagungan teks commedia yang melupakan perempuan dalam konstruksi sejarah yang dibangunnya. Dalam Paradiso canto 16 Dante mengisahkan akar permusuhan dua faksi yang bertikai selama lebih dari dua abad tersebut. Dia menyebutkan bahwa sikap Boundelmonte yang menghianati pertunangan politiknya dan lari bersama kekasihnya bukan hanya mengakibatkan kematian dirinya tetapi juga menyulut perselisihan yang panjang. Dari cerita tersebut, Dante mengabaikan peran perempuan yang mengajak Boundelmonte berkhianat dan juga sikap perempuan yang ditinggalkan Boundelmonte. 
Dante dalam banyak kesempatannya begitu kesulitan menyebut nama perempuan sebagai subjek dalam teksnya. Perempuan-perempuan yang ia jadikan subjek adalah perempuan-perempuan biasa, seperti Beatrice dan Mattilda. Bahkan ketika bertemu dengan Perawan Maria, Dia tidak mengangkatnya sebagai subjek dalam syairnya. Mesikpun telah dibahas pada bab sebelumnya bahwa memilih perempuan biasa yang tidak memiliki historis adalah strategi Dante agar lebih mudah merekayasanya menjadi perempuan-perempuan suci, sosok perempuan ideal yang menjiwai puisi romantika tersebut adalah perempuan-perempuan innocent. Perempuan-perempuan yang tidak pernah terlibat dalam situasi politik yang ada.

Perempuan-perempuan yang memiliki kuasa atas dirinya adalah perempuan-perempuan yang akan dijebloskan ke dalam neraka birahi Dante. Ini menjadi catatan penting bahwa Dante menciptakan neraka untuk mereka yang dianggap menyalahgunakan kuasa yang ada pada dirinya. Satu-satunya kuasa yang harus dikontrol oleh perempuan, menurut Dante, adalah birahi mereka. Dapat dikatakan demikian karena Dante hanya menempatkan perempuan di neraka birahi saja. Perempuan boleh saja bangga dengan ini, akan tetapi Jika ditelaah lebih mendalam, maka neraka ciptaan Dante pada dasarnya adalah konsekuensi dari sebuah loncatan sejarah yang gagal oleh tokoh-tokoh tertentu. Mereka adalah tokoh-tokoh tangguh dengan pengaruh besar seperti Ullyses pemimpin armada perang yang tersesat di lautan, Brutus yang dikenal sebagai pemimpin pemberontakan melawan Julius Caesar, Alexander Agung, dan Frederick II pemimpin perang salib, dan seterusnya. Perempuan di sini tidak lagi 
dilibatkan sebagai bagian dari bangunan kekuasaan yang dilakukan pria. Posisi perempuan adalah posisi yang tipikal sehingga bangunan streotipe terhadap perempuan lebih diutamakan daripada gerakannya.

Perempuan diidentikkan dengan perilaku tertentu daripada apa yang mereka lakukan, atau seperti apa mereka diperlakukan. Dalam The Divine Comedy, Ada tiga streotipe yang ditujukan kepada perempuan. Dari streotipe ini akan tergambar posisi perempuan di dalam teks commedia. Yang pertama, birahi. Neraka birahi adalah satu-satunya neraka yang diperuntukkan kepada perempuan. Tidak ada satupun lingkaran neraka dihuni perempuan kecuali neraka ini. Mereka adalah Helen yang ditemani oleh Paris, Dido, dan Cleopatra. Helen baik dalam Illiad karya Homer maupun Aenead karya Virgil selalu dihubungkan dengan tragedi keruntuhan kerajaan Troy. Pembaca karya-karya sastra Eropa kuno tentunya akan lebih cenderung mengutuk Helen sebagai biang keonaran daripada Paris sebagai pria yang tergoda oleh kecantikan Helen.

Selanjutnya, keadilan akan dipertanyakan ketika Cleopatra dijebloskan Dante ke dalam neraka birahi. Berbicara tentang Cleopatra dan birahi tentunya akan mengarahkan kita pada romantika yang terkenal yaitu perbuatan skandalnya bersama raja Romawi Julius Caesar. Alih-alih menemani sang ratu Mesir tersebut, sang kaisar tersebut tidak dituliskan tenggelam di neraka apapun di dalam Commedia. Hal ini disebabkan neraka tersebut adalah neraka yang paling memalukan. Hanya wanita dan pecundang yang pantas mendapatkan ganjaran karena dianggap telah menghambat jalan seorang pria. Dido dianggap adalah satu di antara beberapa godaan yang mencoba menghambat Aeneas menuju tanah yang 
dijanjikan. Dalam Aenead karya Virgil, Aeneas mencintai Dido sebagaimana Dido juga mencintai Aeneas. Pada hari pernikahan mereka, Aeneas malah pergi meninggalkan Dido, dan karena itu Dido bunuh diri yang menyebabkan angin bertiup sangat kencang, sehingga perahu Aeneas melaju sangat cepat ke tengah laut. Di neraka, Dido, oleh Dante, pun harus menerima hukuman birahi. Ini adalah kerjasama yang baik antara Virgil dan Dante dalam memberikan akhir yang buruk untuk Dido.

Yang kedua, iri dan dengki. Tabel akhirat 2.9 nomor 17 adalah ruang penyucian alam purgatory untuk sifat iri dan dengki. Ini adalah satu-satunya ruang penyucian diri di Purgatory, dimana Dante bercengkrama dengan satusatunya perempuan yang disucikan di alam Purgatory. Nama wanita malang itu adalah Sapia. Ia menyucikan diri dengan menjahit matanya - bentuk penyucian untuk iri dan dengki. Sapia adalah seorang korban politik dari pemerintahnya karena dilaporkan begitu gembira saat kota kelahirannya Siena kalah dalam sebuah pertempuran. Hal ini disebabkan rasa irinya yang berlebihan kepada masyarakat di kotanya.

Yang Ketiga, tidak konsisten atau mudah terbuai. Ini yang dialami wanitawanita di surga Bulan, yaitu Piccarda dan Ratu Constance. Diceritakan mereka menerima ganjaran surga yang paling redup karena menyalahi janji setia mereka terhadap suami atau bahkan Tuhan. Digambarkan surga ini adalah surga yang paling hina, karena cahaya Rahmat dari Tuhan datang hanya sekali waktu dan menghilang di waktu yang lain. Wanita-wanita ini menyesali ketidak berdayaannya dalam mengambil keputusan atas tekanan yang dialaminya semasa 
hidup. Sekali lagi, selain Empyrean, Bulan adalah surga pertama dan terakhir dimana Dante bertemu dengan wanita. Adapun Dante bertemu dengan perempuan lain bernama Rahab di surga Venus dikarenakan Perempuan ini adalah seorang pelacur yang menyelamatkan Jesus dari serangan orang-orang Yahudi. Rahab adalah satu keistimewaan sebagaimana Ripheus dan Statius yang mendapatkan posisi penting di mata Dante.

Klaim ketiga sifat buruk yang dialamatkan pada wanita ini sebenarnya berangkat dari pandangan dunia agama-agama Ibrahimiyah yang meletakkan Eve sebagai sosok yang mudah terhasut dan sekaligus penghasut. Oleh karena peristiwa yang menyebabkan Adam dan Eve diturunkan ke bumi itu, perempuan di setiap zaman harus menanggung streotipe yang dialamatkan pada mereka. Teks Dante menyiksa perempuan melalui oposisi hirarkisnya dengan menempatkan laki-laki sebagai subjek dan pemberi nilai sedangkan perempuan sebagai objek yang dipuja dan bahkan dihina karena perbuatan nistanya. Perempuan tidak memiliki hak atas dirinya disebabkan hasrat/birahi dan penilaiannya atas sesuatu dianggap menyimpang jika tidak didukung oleh laki-laki. Perempuan tidak memiliki hak atas birahinya sendiri sebagaimana tokoh-tokoh perempuan yang direpresentasikan dalam neraka Lust. Perempuan yang menunjukkan kuasa atas seksualitasnya akan hina, sedangkan perempuan yang innocent terhadap percaturan politik adalah perempuan mulia.

Hirarki tersebut tampak dari sejauh mana perempuan mampu menarik diri dari perhelatan politik dan kekuasaan. Beatrice adalah perempuan biasa yang terlahir dari keluarga pedagang. Ia menikah dengan anak seorang bankir karena 
desakan dua belah pihak keluarga, dalam hal ini Beatrice merupakan korban dari pernikahan politik di masanya. Kepasrahan dia dengan nasib yang dialaminya dan juga didukung oleh usianya yang terbilang singkat, yakni 27 tahun membuat dirinya menjadi pendamping Perawan Maria di Empyrean. Berbeda dengan Dido, dia dituduh Dante, dalam The Divine Comedy, sebagai perempuan yang tidak sanggup menahan birahinya setelah menahan kepergian Aeneas, agar menepati janji sang pemimpin Troy tersebut untuk menikahinya.

Fungsi perempuan dalam Commedia terrepresentasi dari novel Inferno saat Sinskey membayangkan lukisan-lukisan Botticelli.

Elizabeth nodded. She and her team had used the internet to identify the painting, which Sinskey had been surprised to learn was a Botticelli, a painter best known for his bright, idealized masterpieces Birth of Venus and Springtime. Sinskey loved both oh those works despite the fact that they portrayed fertility and the creation of life, which only served to remind her of her own tragic inability to conceive - the lone significant regret in her otherwise very productive life. (Brown, 2013: 268)

[Elizabeth mengangguk. Dia dan timnya menggunakan Internet untuk mengidentifikasi lukisan itu, dan dia terkejut ketika mengetahui bahwa itu adalah karya Boticelli, pelukis yang paling terkenal dengan mahakarya cerianya: Birth of Venus dan Spreingtime. Sinskey menyukai kedua karya itu, walaupun sesungguhnya keduanya menggambarkan kesuburan dan penciptaan kehidupan, yang hanya mengingatkan Sinskey pada ketidakmampuan tragisnya sendiri untuk mengandung - satusatunya penyelesalan besar dalam hidupnya.]

Venus dalam mitologi Romawi kuno adalah dewi cinta. Ketika Gereja Roma mengkonversi mitologi Yunani dan Romawi ke dalam Kristen, Venus pun dikonversi sebagai bintang yang muncul di pagi hari dan terang terang di malam hari. Venus diatributkan sebagai pewaris bunda Maria yang menjaga jiwa-jiwa di lautan yang disebut Stella Maris. Seperti yang dilukiskan dalam kutipan di atas, 
jelas bahwa lukisan-lukisan Boticelli yang bertema dewi Venus tersebut mampu menarik perempuan ke fungsi biologisnya, sebagaimana sejarah dan naskahnaskah relijius terangkan. Perempuan yang tersubjeksi oleh narasi Commedia melupakan hakekatnya sebagai manusia yang turut bertanggungjawab dan berperan dalam menciptakan surga dan neraka dalam peradaban manusia. Sebagaimana Hawa menyampaikan pendapatnya kepada Adam, atau Dido yang menahan kepergian Aeneas, dan atau Cleopatra yang menunjukkan perasaan cintanya kepada siapapun yang dia inginkan.

Sikap Vayentha sebagai karakter innocent mengenai sejarah dalam novel Inferno telah menguak tabir pembiaran atas penyiksaan-penyiksaan yang dilakukan terhadap kaumnya (perempuan) sepanjang sejarah, melalui teks-teks agung yang direproduksi setiap periode peradaban manusia. Salah satunya adalah The Divine Comedy. Vayentha hadir mewakili perempuan kekinian yang memberikan respon miris terhadap penindasan tersebut, sehingga wajarlah jika Dan Brown melalui karakter Vayentha menyimpulkan bahwa Commedia adalah violent display of male dominance over women. 


\section{BAB IV}

\section{PENUTUP}

\subsection{Kesimpulan}

Sebagai karya sastra yang lahir di Italia abad ke-14, puisi The Divine Comedy karya Dante Alighieri merupakan teks yang sarat dengan nilai-nilai agama yang kuat. Teks ini menggunakan pola hirarkis yang disesuaikan dengan isi Al-kitab. Pesan-pesan Al-kitab, simbol-simbol mitologi Romawi kuno, dan filsafat bercampur baur dalam latar eskatologi agama-agama Ibrahimiyah. Pengalaman berbentuk perjalanan menuju surga tertinggi, Empyrean adalah cara protagonis dalam menyusun autobiografinya untuk menunjukkan apresiasi respect dan kutukan terhadap tokoh-tokoh atau kebijakan tertentu yang dilakukan oleh pemimpin-pemimpin di masanya dan di masa sebelumnya.

Penyair menggunakan strategi dalam teks agar menciptakan pembaca ideologis yang menyebabkan puisi ini diminati, dianjurkan, dan direproduksi secara massif. Puisi ini berbentuk autobiografi. Autobiografi merupakan strategi teks agar pengarang selalu hadir dan mengawasi teks setiap saat. Pengarang mengungkung teks ke dalam makna yang tunggal. Makna diawasi oleh metafisika kehadiran dimana teks hanya bermain di ranah kepengarangan. Teks menjadi identik dengan pengarang. Pola ini terus diperkuat dengan permainan gaya bahasa alegori. Alegori memberikan kesan bahwa pengarang tidak sendiri dalam membangun sistem teks. Tokoh-tokoh berdialektika dengan protagonist baik secara referensial, atau implisit maupun juga berupa komunikasi yang nyata. 
Sebagaimana struktur bahasa Saussure, sistem neraka dalam teks bersifat tertutup. Setiap tindakan semasa hidup memiliki konsekuensi di akhirat. Perbuatan itu dibangun secara hirarkis dengan sistem operasional yang merujuk pada ajaran dalam doktrin agama Kristen. Tujuh dosa utama diurut sedemikian rupa di gunung Purgatory, dan dicacah di alam Neraka. Setiap ruang yang ada di dalam Neraka, Purgatory, dan Surga memiliki siksaan/ganjarannya sendirisendiri, jenis dosa, dan penghuni yang sebahagian besar adalah tokoh-tokoh ternama. Difference dalam ruang eskatologi Dante menciptakan oposisi biner. Oposisi ini bergradasi dari yang paling hina menuju yang paling mulia, dari Lucifer hingga God Grace. Oposisi biner ini berupa karakter baik lebih mulia daripada jahat, malaikat lebih mulia daripada iblis, Tuhan lebih mulia daripada Lucifer. Di antara dua zat tersebut terdapat simbol-simbol, tokoh-tokoh dan perbuatan-perbuatan yang bergradasi dari yang paling terpuji hingga yang paling terkutuk. Oposisi biner ini juga berupa kelas agama dan ras tertentu. Oleh karena itu, puisi ini direproduksi oleh gereja dan menjadi bahan pembelajaran sastra di sekolah-sekolah dasar di Eropa hingga saat ini.

Novel Inferno karya Dan Brown mengandung teks yang mampu mengaburkan hirarki The Divine Comedy. Pembauran yang sakral dan yang profan dalam teks Commedia tidak serta merta membuat teks tersebut menjadi sakral dan utuh. Autobiografi hanya menciptakan mitos untuk dirinya sendiri. Teks menyisakan trace. Oleh karena itu, Dan Brown melalui pembacaannya yang kritis melalui teks Inferno mampu menyebarkan penanda-penanda yang ada dalam teks. Penanda-penanda tersebut dalam teks Inferno dimanifestasikan ke dalam 
bentuk karya-karya seni yang terinspirasi dari teks Commedia. Karena teks novel Inferno masih mengutamakan pembaca popnya, dekonstruksi teks secara radikal tidak dilakukan sebagaimana karya-karya sastra serius. Pengarang menggunakan strategi rekreatif dengan mempertontonkan karya-karya besar yang tersebar di Itali dan Turki terkait simbol-simbol, tokoh dan, kejadian yang diabadikan dalam teks Commedia.

Petualangan Robert Langdon dan tokoh-tokoh yang ada dalam novel Inferno tidak lepas dari narasi menafsirkan karya-karya seni di Florence, Venesia, dan Istanbul. Karya-karya seni tersebut ditafsirkan secara struktur oleh tokohtokoh mayor seperti Robert Langdon, Felicity Sienna, dan Elizabeth Sinzkey. Begitu pula Teks-teks Dante yang dikutip dalam puisi Bertrand Zobrist, karakter antagonis, merupakan teks yang berfungsi sebagai clue untuk misteri dalam novel tersebut. Tokoh-tokoh ini hanya memberikan respon mengenai kepengarangan teks Commedia, meliputi sejarah, spirit, dan tragedi politik di masa Dante. Dekonstruksi justru hadir melalui tokoh-tokoh minor sebagaimana Derrida mengharapkan kehadiran Other menyebarkan tanda dalam teks. Respon Mirsat, Bruder dan Vayentha terhadap karya-karya seni agung tersebut membuka cakrawala baru dalam menegosiasikan kembali teks Commedia dan konteks

Pembacaan teks Commedia melalui novel Inferno membuka sebuah ruang negosiasi antaraoposisi biner yang secara global mempengaruhi kehidupan toleransi di dunia. Oposisi seperti Kristen lebih mulia daripada Islam, Barat beradab dan Timur barbar, Jesus di Surga tertinggi dan Muhammad di Neraka terdalam adalah contoh-contoh oposisi yang dikandung teks Commedia. Dengan 
kejeliannya, teks Inferno mengaburkan oposisi ini dengan mempertemukan Mirsat dan Bruder di dalam interior Hagia Sophia. Dalam interior itu bersandinglah kaligrafi Muhammad dan lukisan Jesus yang berada di pangkuan Bunda Maria. Dua karakter tersebut memuji Tuhan dengan suasana damai. Dengan cara demikian, oposisi yang dibangun kabur dan meruntuhkan ideologi yang diusung oleh teks.

Begitu pula yang terjadi pada karakter Vayentha. Karakter ini merespon patung-patung karya Michaelangelo yang bersumber dari teks Commedia. Melalui narasinya, respon yang ditunjukkan adalah sikap miris bahwa teks ternyata tidak berlaku adil terhadap gender perempuan. Keberadaan karakter ini begitu penting untuk mempertanyakan kembali posisi perempuan dalam teks Dante. Ini memberikan suatu kesadaran baru bahwa Commedia hanya meletakkan perempuan sebagai second gender dengan melibatkan kaum hawa tersebut sebatas fungsi biologisnya sebagai pencetak anak.

Dengan demikian, Novel Inferno telah memberikan sebuah kontribusi yang berharga dalam setrategi pembacaan teks secara dekonstruksi. Dengan mendekonstruksi oposisi-oposisi yang ada dalam The Divine Comedy, penelitian ini juga telah menguak motivasi mengapa The Divine Comedy menjadi bacaan wajib sebagian besar masyarakat bangsa Eropa sejak dini hingga saat ini di samping loncatan imajinasinya yang melampaui zaman. The Divine Comedy menanamkan ideologi yang kuat tentang kejayaan, dan arogansi peradaban bangsa Angelo tersebut. Oposisi hirarki yang dibangun secara implisit menekankan Eropa sebagai pemilik sekaligus pusat peradaban global. 
Posisi teks novel Inferno adalah sebagai katalisator antara teks The Divine Comedy dan konteks. Simbol-simbol dalam Commedia dioperasikan kembali dengan fakta-fakta simbolik dan kekuatan narasi dalam novel setelah teks novel menawarkan sebuah solusi metaforik bahwa peradaban dunia semestinya berbaur seperti halnya dinding Hagia Sophia yang terlukis simbol-simbol hirarkis itu. Desiminasi simbol dua Logos, yakni Jesus dan Muhammad, tersebut adalah sebuah hope bahwa masa depan perdamaian dua klaim kebudayaan dunia ini bukan hanya sekadar mimpi belaka.

\subsection{Saran}

Hal yang muncul dari penelitian ini adalah bahwa hasil dari penelitian ini bukan akhir dari pembahasan, justru akan membuka kemungkinan pembahasan yang lebih luas. Pembacaan dekonstruksi terhadap The Divine Comedy karya Dante Alighieri melalui novel Inferno karya Dan Brown memang telah sampai pada kadar yang mencukupi dan memenuhi unsur kebaruan yang menjadi semangat eksplorasi di dunia akademik. Akan tetapi penelitian lebih lanjut sangat penting untuk diwujudkan karena pada dasarnya novel Inferno karya Dan Brown memiliki kerumitan teks tersendiri dan juga diprediksi akhir tahun 2015 novel ini mendapatkan penawaran yang sangat besar di pasaran pasca penayangan filmnya, Oleh karena itu, sangat mungkin novel ini akan menjadi salah satu fenomena karya sastra dunia. Tingkat kerumitan teks novel ini juga dapat diteliti dengan berbagai perspektif keilmuan sastra. 
Penelitian mengenai cara baca dekonstruksi yang diterapkan dalam teks sastra sangat diharapkan dapat terwujud dalam penelitian-penelitian selanjutnya. Hal ini berpijak pada fakta bahwa karya-karya sastra/novel Angelo-America kekinian banyak melakukan pembacaan yang dekonstruktif terhadap karya-karya sastra agung sebelumnya yang mengusung ideologi tertentu yang dianggap tidak lagi sejalan dengan semangat kekinian. Pengayaan baik dari segi objek material maupun fenomena yang muncul dalam karya sebenarnya sangat menarik dibahas untuk memperkaya wacana sastra asing, khususnya di lingkup Universitas Gadjah Mada, 


\section{DAFTAR PUSTAKA}

Adi, Ida Rochani. 2011. Fiksi Populer; Teori dan Metode Kajian.Yogyakarta: Pustaka Pelajar.

Al-Fayyadl, Muhammad. 2006. Derrida. Yogyakarta: LKIS

Anugrah, Pinto. 2010. Dekonstruksi Eidos dalam Naskah Drama Dara Jingga Karya Wisran Hadi. Tesis Master (S2). Yogyakarta: Program Studi Ilmu Sastra, Universitas Gadjah Mada.

Asin, Miguel. 1927. Islam and The Divine Comedy. Journal of the Royal Asiatic Society of Great Britain and Ireland (pp.135-137). Cambridge: Cambridge University Press.

Barry, Peter. 2010. Pengantar Komprehensif Teori Sastra dan Budaya Beginning Theory. Yogyakarta: Jalasutra.

Booker, M. Keith. 1996. A Practical Introduction to Literary Theory and Criticism.New York: Longman Publisher USA.

Brown, Dan. 2013. Inferno. Great Britain: Bantam Press.

Cary, Henry F. 1980. The Divine Comedy of Dante Alighieri. New York: Grolier Enterprises Corp.

Culler, Jonathan. 1983. On Deconstruction; Theory and Critism After Structuralism. London: Routledge and Kegan Paul.

Derrida, Jacques. 1981. Dissemination; Translated, with an introduction and additional Notes, by Barbara Johnson. London: Athlone Press

Durling, Robert. M. 1996. Volume I The Divine Comedy of Dante Alighieri; Inferno. New York: Oxford University Press

New York: Oxford University Press 
Faruk. 2012. Metode Penelitian Sastra; Sebuah Penjelajahan Awal. Yogyakarta: Pustaka Pelajar.

Franke, William. 2012. Dante's Deconstruction and Reconstruction of Prophetic Voice and Vision in the Malebogne. Philosophy and Literature, Volume 36, Number 1, pp. 111-121. Maryland: The John Hopkins University Press.

Hofstadler, Albert. 2001. Martin Heidegger; Poetry, Language, Thought. New York: Perennial Classic.

Lenz, Milicent. 1994. “Am I my Planet's keeper?”; Dante, Ecosophy, and Children Books. Children's Literature Association Quartely, Volume 19, Number 4. Maryland: The John Hopkins University Press.

Lewis, David Levering. 2012. The Greatness of Al-Andalus; Ketika Islam Mewarnai Peradaban Barat. Jakarta: Serambi Ilmu Semesta.

Lauretis, Teresa De. 1990. Feminism and its Differences. Pacific Coast Philology, Vol. 25, No. 1/2 (Nov., 1990), pp. 24-30. Pennsylvania: Penn State University Press. Maslin, Janet. May 12, 2003 On a Scavanger Hunt to Save Most Humans; Inferno by Dan Brown. New York: The New York Times.

Mashuri. 2013. Dekonstruksi Wayang dalam Novel Durga Umayi. Poetika, Jurnal Ilmu Sastra Vol: 1, No: 1. Yogyakarta: Prodi S2 Ilmu Sastra UGM.

Niven, Larry and Pournelle, Jerry. 1976. Inferno. New York: Pocket Books

Panter, Gery. 1997. Jimbo's Inferno. New York: Fantagraphics

Pearl, Matthew. 2003. The Dante Club; a Novel uncovering murders mystery Inspired by Dante Alighieri's The Divine Comedy. New York: Random House Trade Paperback. 
Pujiyanti, Fariska. 2010. Dekonstruksi Dominasi Laki-laki dalam Novel The Da Vinci Karya Dan Brown. Tesis Master (S2). Semarang: Program Pascasarjana Magister Ilmu Susastra Universitas Diponegoro, Semarang

Rogak, Lisa. 2013. Dan Brown: a Biography; Kisah Hidup Seorang Novelis Paling Kontraversial abad ke-21, terj. Harisa Permatasari. Yogyakarta: Bentang Pustaka

Sarup, Madan. 2008. Panduan Pengantar untuk Memahami Postrukturalisme dan Posmodernisme. Yogyakarta: Jalasutra.

Sturrock, John. 1979. Structuralism and Since; from Levi-Strauss to Derrida. Oxford: Oxford University Press.

Sunardi, St. 1996. Nietzche. Yogyakarta: LKIS

Sutandio, Anton. 2003. Pembacaan Dekonstruksi dari 4 Novel Karya Stephen King dalam Konteks Ideologi Rasisme dan Anti-Rasisme. Depok: Program Pascasarjana Magister Ilmu Sastra Universitas Indonesia, Depok.

Tembling, Jeremy. 2007. Allegory; The New Critical Idiom. New York and London: Routledge

Wellek, Rene dan Austin Warren. 1995. Teori Kesusastraan. Jakarta: Gramedia Pustaka Utama.

Wood, David. 1992. Derrida: A Critical Reader. Cambridge: Blackwell. 


\section{PERNYATAAN \\ PERSETUJUAN PUBLIKASI KARYA \\ TULIS}

Saya, yang bertanda tangan di bawah ini

nama

ZLLRIFLI.M

tempat / tanggal lahir

UJUNG PANDANG, 17 JULI 1984

NIM

12/337395/PSA/07194

mengizinkan kepada Perpustakaan Fakultas Ilmu Budaya UGM untuk memublikasikan karya tulis ilmiah saya ke portal Perpustakaan FIB dengan ketentuan:

1) materi yang boleh dipublikasikan:(pilih salah satu)*

\#. judul,abstrak,dan daftar isi saja ;

(b) seluruh bagian karya tulis ;

2) dengan ketentuan sekuritas:(pilih salah satu) *

(a.) materi hanya boleh dibaca dengan format digital ;

b. materi boleh dibaca dan diunduh (download).

pernyataan ini saya buat dengan sungguh-sungguh dan tanpa tekanan dari pihak manapun

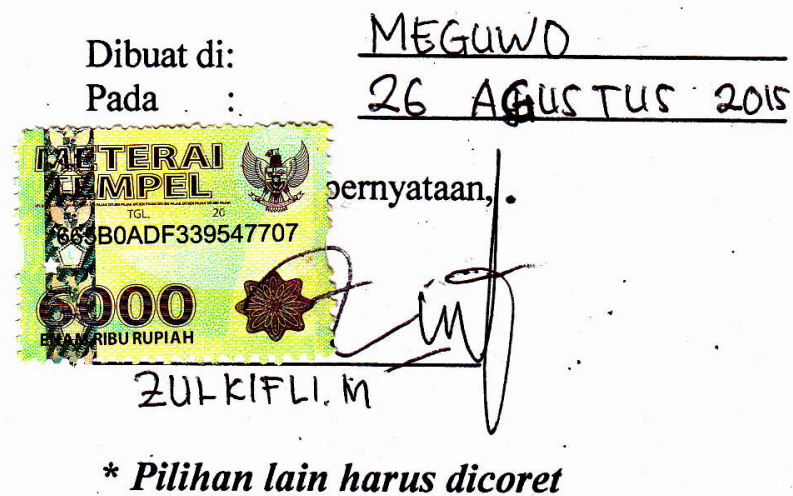

